\title{
Evolutionary and heterodox innovation analysis : a study of industrial and technological development in process control and information technology
}

Citation for published version (APA):

Hagedoorn, J. (1988). Evolutionary and heterodox innovation analysis : a study of industrial and technological development in process control and information technology. [Doctoral Thesis, Maastricht University]. Rijksuniversiteit Limburg. https://doi.org/10.26481/dis.19881201jh

Document status and date:

Published: 01/01/1988

DOI:

10.26481/dis.19881201jh

Document Version:

Publisher's PDF, also known as Version of record

Please check the document version of this publication:

- A submitted manuscript is the version of the article upon submission and before peer-review. There can be important differences between the submitted version and the official published version of record.

People interested in the research are advised to contact the author for the final version of the publication, or visit the DOI to the publisher's website.

- The final author version and the galley proof are versions of the publication after peer review.

- The final published version features the final layout of the paper including the volume, issue and page numbers.

Link to publication

\footnotetext{
General rights rights.

- You may freely distribute the URL identifying the publication in the public portal. please follow below link for the End User Agreement:

www.umlib.nl/taverne-license

Take down policy

If you believe that this document breaches copyright please contact us at:

repository@maastrichtuniversity.nl

providing details and we will investigate your claim.
}

Copyright and moral rights for the publications made accessible in the public portal are retained by the authors and/or other copyright owners and it is a condition of accessing publications that users recognise and abide by the legal requirements associated with these

- Users may download and print one copy of any publication from the public portal for the purpose of private study or research.

- You may not further distribute the material or use it for any profit-making activity or commercial gain

If the publication is distributed under the terms of Article 25fa of the Dutch Copyright Act, indicated by the "Taverne" license above, 
EVOLUTIONARY AND HETERODOX INNOVATION ANALYSIS -

A STUDY OF INDUSTRIAL AND TECHNOLOGICAL DEVELOPMENT

IN PROCESS CONTROL AND INFORMATION TECHNOLOGY

PROEFSCHRIFT

ter verkrijging van de graad van doctor aan de Rijksuniversteft Limburg te Maastricht, op gezag van de Rector Magnificus, Prof. Dr. F.I.M. Bonke, volgens het beslult van het College van Dekanen, in het openbaar te verdedigen op donderdag, 1 december 1988 om 16.00 uur

\author{
door \\ Johan Hagedoorn \\ geboren te "s Gravenhage in Nederland
}


Promotar: Prof., Dr. L.L.G. Soete

Beoordelingscomissie: Prof. Dr. H. Schreuder

Prof. Dr* C. Freeman

Prof. Dr. A. RIP

De totstandkoming van dit proefschrlft is mogelifk gemakt door Elnanclèle ondersteuning van de Programmacommissle TechnologieEconomie, het Studiecentrum voor Technologie en Beleld TNo en de Commissle van de Europese Gemeenschap. 
1. Introduction

2. Marx's and Schumpeter's theorles of Industrial and technological development

2.2 Marx and Schumpeter: their theoretical

'antecedents'

2.3 Marx's and Schumpeter's theories of economic and technological developnent

Accumulation, economic crises and technology in Marx

Schumpeter on business cycles and technology

2.4 Marx and Schumpeter on technology and innovation

Marx on the forces of production and technology

2.5 Competition, differentiation of companies and technological developwent

Competition, monopoly and technical change

Entrepreneurs, new compantes and large corporations 
3. Radical and neo-Schumeterian theories of Innovation

3.2 Neo-Marxist theorles of competition, differentiation of companles and technology

Competition and monopoly or oligopoly

Sweezy"s theory of monopoly capitalism and technological development

Dead-endsi in neo-Marxist theorles

3.3 The Schumpeter controversy

Schumpeter and Galbraith: large companies and Industrial concentration

Smal1 compantes, some nuances and neoSchumpeterian approaches

3.4 Emplrical studies on the Schumpeter controversy

Market structure and Innovation

Innovation and firm size

104

3.5 Innovation and technologleal opportunity 109

3.6 Categories of compantes and Innovation strategles 
3.7 An analytical framework for the analysis of industry structures and innovation

4. Technological development and diffusion as an evolutionary process - information technology and process contral

4.1. Introduction

4.2. Technological trends in process technologies, Information technology and process contral

Technological paradigms in process technologies, information technology and process control

Basic designs and key-elements in process control rechnology

Technological trajectories and generations in keyelements of process control

Measurement of technological trajectorles

Technological development as an evolutionary process

4.3. Diffusion and technologtcal development

Stylized patterns of diffusion

Factors influencing diffusion

Measuring diffusion of information technology in process control 
Difusion of information technology in the internat lonal process control equipment sector

5. Structure and Innovat1ve performance of the Internatlonal process control equipment industry

5.1. Introduction

5.2. Structure of the process contro1 equiprent Industry

Industrial development and "creative destruction" in the p.c.e. industry

Different categortes of p.c.e. companies

5.3. Size and Innovation in the p.c.e. Industry

Size and R\&D

Size and product-related indicators of innovation

5.4. Innovation strategles in the industry 200

5.5. Some conclustons 205

6. Some conclustons on technological and sectoral development

Elements of an evolutionary theory of technological change 
Page

Technological change and 1 ts selection

environment $\quad 216$

Indicators of Innovative performance 218

Consequences for Innovation policles 221

$\begin{array}{ll}\text { Appendix 1 } & 223\end{array}$

$\begin{array}{ll}\text { Appendix } 2 & 225\end{array}$

$\begin{array}{ll}\text { Appendix } 3 & 226\end{array}$

$\begin{array}{ll}\text { Append 1x } 4 & 227\end{array}$

$\begin{array}{ll}\text { Append1x } 5 & 228\end{array}$

$\begin{array}{ll}\text { Append } 1 \times 6 & 229\end{array}$

$\begin{array}{ll}\text { Append1x } 7 & 230\end{array}$

Bibliography 231

Nederlandse samenvatt1ng 246

Curriculum vitae $\quad 254$ 

Judging by the number of recent publications in economics in which technologlcal development is an important subject of elther emplrIcal or theoretical study one would suspect that the economic profession has re-discovered technology as a major issue to be studied serlously. In so far as this discovery has led to a growth In the quantity of research coupled wth a search for new departures of both theoretical and empirical research, the qualitative yleld so far has been moderate. With few exceptions, the present research agenda of mainstream economics has not been changed with respect to basic ideas about technological change and innovation, the character of issues to be studied, the complexity of the subject and the consequences to the measurement of innovation and technology and empirical research.

It is this orthodoxy which led some economists, e.g. Nelson and Winter, to emphasize the need for a widening of the scope of economic analysis, in particular to the understanding of the relationship between technological and economic change ${ }^{1)}$. This study is an attempt to contribute to an alternative analysis of technological change in its dialectical relation to changing industry structures. It bullds on some older and some more recent contributions to innovation theory and industrial economics which share a common background in the1r heterodoxy. The emphasis in this study is on some elaborations to these alternative contributions and more particularly on some new departures in empirical research.

Thls publication is also one of the results of larger research program at the Centre for Technology and Policy studies TNO in which technolog1cal, economic and social aspectis of sophisticated automated manufacturing have been studied. The research program focused in particular on the empirical analysis of this field of

1) See R.R. Nelson and S.G. Winter. An evolutionary theory of economic change, 1982 , and also e.g. N. Clark, Introduction: economic analysig and technologlcal change - review of ome recent developments, in: R. MacLead, 1986. 
technologlcel development. Due to the emplrical and applled character of the research, theoretical and conceptual elaboration was not an objective in itself. If such elaborations were performed, their function with this reseacch program was narrowly related to the expicical research being undertaken ${ }^{1}$. In the present study attention is pald to both theoretical dewelopments in inmovation theory and the testing of an alternative approach to Innovation research. The major topica in this research are developments in information technology, process technologles and process control and their interrelationsips. The research focuses not only on the analys 18 of technological developnent but also on changes in the relevant industry structures and the innovative performance of companies involved in this fleld.

The research is somewhet experimental reflecting contributions to economic theory made by so-called evolutionary approaches and the 1nterdisciplinary study of technology measurement. The emphasis in this study w11 be on some heterodox contributions to innowation theory in which the investigation of technological development 1tself is at the core of the research agenda. In such evolutionary approaches elements of a mon neo-classical theoretical framework are found in an amalytical framework in which technological development is studled in terms of technological paradigms, basic designs and technological trajectorles. Changes in technology and Industry structures, disequilibrium, asymetry of companies. endogenous selection mechanisms and explicit attention to the consequences of technological development are important features of these contributions to an alternative theory.

1) See e.8. I. Hagedoorn, P. Kalff and J, Korpel, Technologlcal. development as an evolutionary process, 1988, R.H. B1lderbeek and B.C.M. Alders, Advanced production systems and training implications, in: W.L. Buitelaar (ed.), 1988 and F. Prakke, Introducing CIM in the factory organization, 1987 for examples of empirical studies within this research program focusing on the in-depth study of technological development. 
Such an alternative approach is quite distinct from one taken by the traditional theory of innovation and industrial development. The traditional theory of innovation is to a large extent related to the orthodox theory of the firm based on the paradigm of profit maximization by economic subjects as a behavioural hypothesis. The roots of this neo-classical theory of the flim can be traced back to the theory of value whlch dominated the second half of the 19th and the early 20th century. Baslc notions of the theory of the firm at this early stage were perfect competition and perfect knowledge which together led to the assumption of general equilibrfum. Technological change was an exogenous factor and characterized as a smooth process of adoption with gradual changes and universal availability. At the end of the 1920's the Marshallian varlant to the classical theory of the firm, whlch included partlal equllibrium, was fundamentally questioned by many economlsts and in particular by Sraffa, Roblinson and Chamberlin. Despite the criticlsm and alternative theorles put forward since then, the basic idea of the present neo-classical theory of the firm, as found particularly in textbooks, has remalned largely unchanged as a partial equilibrium analysis assuming profit maximization in an exogenously given environment. The general framework of such assumptions builds on the notions of the company as a "... hollstic firm maximizing profits under conditlons of complete certainty"1). Uncertainty about the outcome of innovative activities, asymmetry of companies regarding the appropriation of returns on innovative inputs and disequilibrium effects of changing market structures are far removed from the bastc assumptons of this orthodox theory of the f1rm.

Within the traditional theory criticism has been countered by technical elaborations and the introduction of theorfes with more complex conflgurations of for example multi-product companies and oligapoly. At the same time the assumption of profit maximization has been modified by the introduction of the behavioural assumption of proftt maxtmization in the long run.

1) D.A. Hay and D.J. Morris, Industr1al economics, 1980, p. 232 . 
At the fringes of the theory of the fira several theoretical contributions we made which culminated in behavioural and managertwist theories. Although technological development and innovation are sometimes mentioned in such approaches they have never been at the core of these partlcular alternative theorles of the firm.

In recent years a number of contributions to economic theory have been made in which assumptions from neo-classical inspired theorles of technology and economics have been crittcized. Contributhons such as those made by Helson and Winter, Rosenberg, Dosi and Freeman and hls colleagues, to name but few contributors to the debate, are not only interesting with respect to theoretical 1ssues but they also provide some analytical tools for empirical research on technological development. It is in particular in the context of the empirical research undertaken in this study that such contributions 111 be analyzed and, if necessary, elaborated upon.

In any study cholces have to be made regarding the theoretical background and whether to incorporate particular theorems. In this study a cholce ls made for contributions which are somewhat off malnstream economics. Making such a cholce does not imply that there are no interesting theoretical developments being generated within particular schools from more conventional economic theory. Many modern theories of innovation, which are st 111 influenced by neo-classical theory, go beyond some of the more simplistic assumptions of orthodox theory mentioned before. In modern theory of innowation a substantial share of the analytical-theoretical contributions is based on game-theoretic approaches 1$)$. Analytical and mathematical rigour is characteristic of such approaches and pirlcal malysts is usually not a major effort as the analytical atructure is central to this approach. Applied and also enpirical research have recently been put on the agenda of such approaches but the analytical content sets certain atandards to the qual1ty" of emplrical material which w111 sometimes appear to be too

1) See e.g. M.I. Kamien and N.L. Schwartz, Market structure and Innovat lon, 1982 and A. Jacquemin, selection et pouvolr dan $1 a$ nouvelle economie Industrtelle, 1986. 
high for particular categorles of emplrical research. In this study an attempt is made to apply empirical research with an experimental, analytical framework in a relatively unknown, and in a sense, new Industry which lacks officlal statistical data. Under those circumstances in which the discovery of elementary empirfcal facts and data were essential certain standardized methods of empirical research such as survey research seemed more appropriate.

In many of the contributions to Innovation theory to be discussed an effort is made to widen the scope of research and theory. As such an effort is wade to pay attention to some heterodox theories of technological and Industrlal development. In particular, theories and research inspired by schumpeter and Marx are truly unorthodox in the sense that they diverge from conventional approaches. Both these approaches stand out in the history of economic theory as contributions in which innovation plays a more than complementary role. From the perspective of a search for new departures as they appear in the innovation 11 terature it will be useful to discuss bath the orlginal contributions by Marx and Schumpeter and the debate that followed the neo-Schumpeterian and neo-Marxist traditions, as well as some other heterodox contributions labelled as evolutionary approaches.

Whereas Schumpeter"s contribution fell largely within the accepted academic tradition of economic theory much of his work was nevertheless largely neglected until a decade ago. As will be explained in chapter 2 , his contribution stands out with respect to the attention pald to the effects of technologlcal development on the dynamics of a cap1talist economy. Although schumpeter is often referred to as one of the economists who pald considerable attention to Innovation one sometimes gets the Impression that few have actually read a substantial share of hls contributions to the subject. His theory 18 at 111 intellectually stimulating and relevant to modern analysis of technological development. I believe that the elaborations upon his work as undertaken in the following chapters will demonstrate the legltimate character of such an exerclse. Of course, Schumpeter's theory has certaln flaws, but 
I belleve $1 \mathrm{t}$ goes too far to accept Thirtle and Ruttan's recent criticism that ". : the Schumeterian system has remained an obstacle to the efforts by econamists to understand the process of technical innovation"1). A more subtle apprectation of the Schumpererian syotem w11 enable me to assess some madern neoSchumpeterian contributlons, relevant to analyzing changing industry structures and the Innovative performance of compantes, in the $11 \mathrm{ght}$ of their antecedents.

Many of the present 1 saves in the debate on Innovation and its economlc consequences were already discussed by schumpeter although their presentation is not always very conventent. Schumpeter discussed innovation with respect to the role of the entrepreneur but also as an endogenous factor effecting economic change through large science based compantes. As will be demonstrated in the analysis of the Schumpeterian system, Schumpeter"s theory leaves more opportunity for subtle theorizing than could be concluded from many superficial interpretations of his contributions. In particular schumpeter's advice to study the destruction of the older and the creation of new industry structures coupled with the analysts of company behaviour appears fruttul for any attempt to analyze industrial change.

Contrary to Schumeter, Marx has hardly been accepted within the economic profession although his name is frequently mentioned when the relationship between economic and technological development is discussed. Marx's theory can be seen as one of the earlier contributions to evolutionary theory of economic change in which technologlcal development played substantial role. In his theory technological development acted as a disequllibrium force generwing at least part of the causes of economic crlses. Marx was M1so one of the flrst to stress the growing importance of the Interaction of sclence and technology in modern capitalist society. And like schumpeter he discussed transient monopoly and incidental extra profits as a stimulus to innovation.

1) C.G. Thirtle and V.W. Ruttan; The role of demand and supply in the generation and diffusion of technical change, 1987, p. 5. 
In this study I can only assess the relevance of Marxlst contributions to some major issues in industrial economics and innovation theory. It Is definitely not an objective of this study to contribute to a general theory of radical economics. From the perspective of radical economic theory the objectives of this study are rather pragmatic. Just as much as it could be helpful to conventional theory to widen its scope it could be useful to a neoMarxist approach to consider some innovative changes in its theoretical background.

The choice for a study of contributions from such unconventional theories in order to widen the scope of the present research agenda does not necessarily lead to the acceptance of the complete theory of such schools of thought and neither does it have to lead to a superficial synthesis of particular aspects. What it can do is to demonstrate that particular issues in Innovation theory are not as new as one 1 s sometimes inclined to assume. Going back to the classics can also prove to be useful to understanding the theoretical background of modern theories.

In some neo-Marxist theories as well as in some neo-Schumpeterian theories economic and technological development is analyzed in the context of the role large, multinational compantes play. In such approaches monopoly is no longer size-independent and short-run but a long-rum and static phenomenon and technological development Is no longer a dynamic factor but subordinate to the strategy of a small number of dominant companies.

In some other attempts to analyze and theorize the relationship between technology and the development of markets and compantes, the relationship between company size, market structure and Innovation has been a major focal point of research in the past decades. The results have been somewhat disappointing compared to the intellectual Investments made. Some advantages have been made by fncluding technological opportunity as a factor explaining sectoral differences. In this study the scope of the analysis 18 widened by including not only technological opportunity but also a categorization of companles and a set of different innovation strategies. Such an approach allows one to take into account the 
complextty and differences in technological developments, the non-uniformity of companies and the alternatives in company-behaviour. Swch a wore differentlated analytical setting in which a number of behavioural alternatives are introduced $1 \mathrm{~s}$ an imanent criticism of the Matshallian theory of the 'representative firm' typical for a particular industry. It is lso different from at tempte to analyze company behaviour and Industry structures form a theory of successful flrms as e.g. advocated by Arnold ${ }^{1}$. I agree that "... a theory whlch describes the whole universe of posslble firm behaviour $1811 \mathrm{kely}$ to be so broad as to be of 1ttrle use ..."2). However, I fall to see why the analysts should be restricted to successful firms which "survive major technical changes in a similar market as before'. First, as will be demonstrated below, it is possible to abstract from the whole universe of firm behaviour tnto a number of relevant strategies. Second, the search for theory of only successful firms is a too restrictive objective which could be compared to e.g. medical science studying only healthy people and paychiatry to theorize sanity without reference to other mental conditions. Third, in such an approach the dynamic perspective is lost because todays success is no guarantee for success during the day-after-tomorrow. Fourth, technology becomes an exogenous factor 1 success is studied in terms of surviving technical change quite passively while, if technical change is taken to be more endogenous, different strategles have various effects on introducing technical change. And finally, a study of the effects of technical change on company success has to been seen within the interaction of different categortes of companies in the wider context of competition and changes in Industrial structures.

The alternative analysis of technological development in evolutionary theory is reflected in an analytical framework which features concepts which are quite different from those applied In more conventional research. Technological development can be analyzed in terms of changes within or frow existing technological

1) See E. Arnold, Competition and technological change in the 2) Idem, p. 9 . 
paradigms of major flelds of technology. Such an analys is provides the very first insights into changes In techmology. For a wore applied economic understanding of these changes it will be necessary to achieve a more concrete understanding of changes in socalled technological trajectorles and baslc designs.

In such framework, to be elaborated upon below, it is possible to pay attention to both gradual and more radical changes which characterize technological development. Another feature of the analysis in this study is the integration of diffusion and innovation as different aspects of technological development. In this Integrated approach concrete innovative aspects of technological development are seen as a process of both the creatlon of new products or processes and the incremental change of technology in a process of diffusion which is not just a matter of adoption but of gradual change during the dissemination of an innovation or a new technology.

The emphasis in this study is on the feasibility of empirical research on technological development and changes in industry structures with an alternative analytical framework. Such an approach places certain limitations on the number of technologies and sectors of industry to be studied. In the research program of which this study is a part, process control technology was chosen as a core technology. Studying this field of technology enables me to pay attention to a number of other technologies which interact with modern control technology, 1.e. Information technology and process technologies. Furthermore, the economic setting of the $\mathbb{1 n}$ dustry producing process control systems can be related to economic and technologleal developments in adjacent fields of production.

Process control is a field of technology in which systems and stand-alone equipment are applied to regulate, determine and maintain the desired values and conditions of production processes. In the peist hundred years the technology has changed from simple manual process regulation to advanced automatic control. There are st111 some differences between control in so-called discrete manufacturing wh CAD/CAM systems and process control systems, but in 
partleular the system archttecture and general features of contral In both forms of production demonstrate similar trends in control technology.

As mentioned before, process control technology is at the intersection of a number of technological developments in process industries and information technology. Due to this interaction attention can be concentrated on a larger number of trends in technologtcal development than would be the case in a stralghtforward ingle-sector study. Both the sectoral and technological developments are studied in the wider cantext of related sectors and technologles.

Another feature of this study is the cholce of a sector of Industry in 1 ts international setting which is neglected in offlcial economlc statistics. The sector emerged from the traditional measurement equipment sector and developed into a sector closely related to the electronics and information processing sector. One of the objectives of this research is to demonstrate the possibilities of economic research on 'new' sectors before official statistical Information bas caught up with changes in the industrial structure. The lack of such officlal information sets certain limitations to the quantity of information. This shortcoming can only be countered by developing one"s own materlal. In this study survey research was chosen as the major source of information on the industry structure and innovative performance of companies. As far as the information on innovative performance is concerned survey research has had particular advantages for the present research, In which indicators of Innovation have been applied whleh differ to a large extent from those applied ln most other studies. This approach enabled me to study the actual companies producing process control systems and devices and to develop or IgInal Indicators of technological development and Innovation which sult the analytical framework and the complexity of the specifle sector. The size of the survey ls rather limited since it refers to 56 companiles. Desplte the small number of companies the survey has some important features whlch increases the relevance of the information and go beyond the signiflcance In terms of 
sheer numbers. First, the survey is not restricted to a national sector but it covers the international process control industry. Second, more than $80 \%$ of the world-leading companies in de industry participated in the survey.

In the following chapters the theoretical background of the present study will first be developed and the empirical analysis will then be presented in relation to this background.

Chapter 2 focuses on the classical contributions to Innovation theory made by Marx and Schumpeter. The general background of their theorles and some major issues with respect to economic and technological development will be the subject of a critical review. Particular attention will be pald to those subjects which are still discussed in the modern ifterature such as the role of different categories of companies, Innovation and monopoly, the endogenous or exogenous character of technical change, and the attempts made to understand technological development as a process of evolutionary change.

In chapter 3 the 'offspring' of Marxist and schumpeterian theories is discussed in order to investigate whether some dead-ends in the original theorles have been overcome in modern versions. A part of the debate in these theorles concentrates on the subject of the relationship between size of companies, monopoly and innovation. The fmpact of both theoretical and emplrical studies will be discussed. In both neo-Schumpeterian and neo-Marxist theorjes there are static as well as more dynamic interpretations of the above mentioned relationship. The dynamic approach is extended into a new theoretical framework in which changes in technological opportunities, a differentiation into categories of companies and a set of alternat1ve Innovation strategles are incorporated.

At that stage of the analysis the focus of the study switches to one which will pay extensive attention to the analysis of technological development. The objective of chapter 4 is to provide some analytical tools to the understanding of technology and technological opportunities. Major bullding blocks in such a framework are 'technological paradigms", "baslc designs', "key-elements" and

'technologlcal trajectorles'. concepts which can be applied to the 
analysis of technological development at several levels of abatraction and 1 in different degrees of generality and particular1ty. Technological change w11 be analyzed not only as development of forward moving frontiers of so-called 'best practice" technologies but also in terms of the pattern of diffusion. That specific context enables to criticize the traditional static theory of diffusion. In order to limit the abstract character of such a discourse the analys1s is applied to the study of technological change and patterns of diffusion of information technology in process control.

Parts of the empirlcal analysis in chapter 4 are based upon the survey of the international process control industry. The results of the survey and some other empirical 1nputs are extensively reported and analyzed in chapter 5 . This chapter concentrates on the character of industrial change in this sector during the past decades and the role different categories of companies play in generating finnovation and technological change. The content of Innovation strategles in this sector of industry are analyzed as wel1. The feastb1lity of an alternative theoretical and analytical framework in empirical research is demonstrated in particular in chapters 4 and 5 .

The general results of this study and the theoretical notions which support the approach chosen are briefly iterated and evaluated in a concluding chapter. 
The main objective of this chapter is to present an outline and assessment of some of the major issues in the theories of Marx and Schumpeter. In the following 1 will pay attention to those elements of their theories which are related to issues in modern industrial economics and Innovation theory. Both Marx and Schumpeter studied many subfects in social sciences - economics, soclology. political science, economic history - and many of these subjects are far removed from the issues touched upon in this study. It is not my intention to reconstruct the wide bodies of soclal theory laid out by both. I can only evaluate certain elenents of their theorles and as such $I$ do not intend to assess all the contributions Marx and Schumpeter made to social sclence or even just economics.

I w111 start off with a somewhat broader scope to place both Marx and schumpeter in their 'theoretical setting'. In reference to their theoretical context it is clear that Marx and Schumpeter came from completely different theoretical backgrounds and eras in the history of economic thought. Marx's writings on economic 1ssues were connected with both theoretical and emplrical developments in the second half of the nineteenth century. His theoretical work critically reflected the clasical political economy, whlle the emplrical counterpart dealt with the consequences of the Industrial revolution and the development of modern Industry, contrasting a previous system which was based upon namufacture.

Compared to Marx Schumpeter's background In economic theory was more diverse and influenced by economists from different schools of thought. It was far removed from classical political economy and clearly embedded in the marginalist tradition. However, schumpeter's attention to disequilibrlum-effects of innovation makes his work distinctly different from orthodox neo-classical economic theory. The attention pald to supply-side factors in economic development, the absence of demand as major issue, and 
the abstraction from the state in most of his considerations places Schumpeter, 11 ke Marx, far from the Keynesian tradition. If one is to typlfy Schumpeter" $s$ theory in one word then 'evolutionary" w11 probably be most appropriate.

Desplte differences between Marx and Schumpeter the1r work does Indicate many elmilar interesta. For both, technological development, In schumpter preferably innovation, was at the core of their theorles. And most important, technological development. played an lmportant role in thetr understanding of evolution in capitallst soctety. In some of the following sections I w11 discuss the role technology played in both theorles as well as pay attention to the conceptualization of technology by Marx and Schumpeter.

It 16 we11-known that technology in its interaction with economic development st111 plays a minor role In most of modern economlc theory and analysis. Technology is frequently either completely neglected, modelled as the unknown factor, or otherwlse 'maltreated". In both Schumpeter and Marx one finds clear attempts to understand some of what 1s nowadays known as the 'black box' of technology. In these attempts both pald attention to macro-economic 1ssues as well as issues more closely related to industrial economics and innovation theory. This study focuses on the latter two flelds, and in particular on the theorles of competition, industrial structure and innovation. It is also in these particular fields of theory that Marx and Schumpeter demonstrated some clear similarities. Here convergence lo more vivid than schumpeter sometimes seemed w111ing to admit.

It has to be stressed that the objective of this part of my study Is not only to point out simflarities and achlevements of the contributions made to economic theory of Marx and Schumpeter. It 1s much more Intended to assess where both theorles are complementary, which elements are in a clear need of elaboration and where 'dead-ends', from the perspective of Innovation theory and industrital economica, re to be found. Through this assessment of the works of two of the most Influential economlsts theorlzing technologlcal development, the general framework for understanding some modern heterodox economic theory of Innovation is set. 
In order to get that far in the following sections I will proceed from the more general perspectives of Marx and Schumpeter to specific subjects related to what is nowadays known in industrial economics as 'the continuing debate on market structure, firm size and innovation'. I w11l first present a short discussion of the theoretical 'antecedents' of Marx and Schumpeter, followed by their theories of technological and economic development. The attempts made by Marx and Schumpeter to conceptualize technology and innovation are also discussed because both stand out as two of but few economists who have something to say about the Inslde of the 'black box' called technollogy. From there I w111 proceed with a comparison and interpretation of both theories with respect to competition, differentiation of company-size and industrial concentration. The final section of this chapter is devoted to an assessment of dead-ends and possible new departures from Marx and Schumpeter.

Some authors, notably Rosenberg and Elliott, stress slmilarities between Marx and Schumpeter in their common vision on economic progress ${ }^{1)}$. Rosenberg mentions that both had similar research agendas which addressed lssues such as:

- growth of size of companfes and industrial concentration;

- instability and crises within capitalism,

- the destruction of captialism and arrival of a socialist form of economic organization ${ }^{2}$.

Despite such general simlarities it must however be made clear from the outset that the works of Marx and schumpeter are also quite different. Not only do some baslc notlons have different meanings but their theorles and analyses also refer to different periods of economic development and theory.

1) See e.g. N. Rosenberg, Schumpeter and Marx: how common a vision? In: R. Macleod, Technology and the human prospect, 1986 and J.E. E1liott, Marx and Schumpeter on capitalian"s creative destruction: a comparative restatement, in: Quarterly Journal of Economics, August 1980 .

2) See N. Rosenberg, 1986, p. 199. 
Marx"s theory had been influenced to a large extent by three diferent soctal and sclentific movements in the late eighteenth and first half of the nineteenth century. Marx"s philosophlcal bastc Ideas on dialectlcs and materlalism had been formed in a crittcal reflection of German philosophical ideelisw and matertal1am His soclallst polltical "praxis" was influenced by french utoptan soclallsm. Marx's theory of economic development and his critique of clasalcal political economics was in particular related to a concrete understanding of economic development in the most advanced capitallst soclety of the nineteenth century, the Unlted KIngdon, and the to works of Engl1sh/Scottish classical polltical economists.

From all the classical political economists it was Ricardo who has had a far-reaching influence on Marx's theory of socio-economic development. Ricardo's contribution to Marx's theory is in particular related to such lssues as income distribution between different soctal classes and the labour theory of value. There is also a line from kicardo to Marx regarding the understanding of technical progress although Ricardo pald but limited attention to technical development as demonstrated in the earlier editions of the Princlples of Political Economy and Taxation. The issue of mechanlzation was only brlefly mentioned by Ricardo in his debate with Malthus on the effects of mechinery and accumulation on the rate of profit ${ }^{1}$. It was not unt1l the third edition of the 'Principles ...' that the well-known chapter on Machinery was fincluded. Here Rlcardo stressed the consequences of mechanlization on the composition of capltal, on a constantly risting ratio of machinery to labour, and on the level of employment. Ricardo's chapter on machinery remalned somewhat $11 \mathrm{ke}$ a "blank spot' in his general theory. E.g. the substitution of capltal for labour contradicted Rlcardo's general assumption that capital and labour would grow at equal rates ${ }^{2}$.

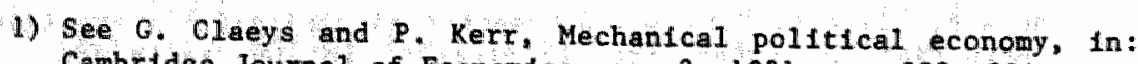
Cambrlage Journal of Economics, no. 3. 1981, pp. 253, 254.

2) See A. Heertje, Economics and technical change, 1977, pp. 14-20 and $M$. Blaug, Economic theory in retrospect, 1983 (1962), for neat 'sumarles" of Ricardo's chapter "On Machinery". 
So Ricardo did pay some attention to technical change but it was examined within a theoretical framework which left 11ttle room for technical change. Since Ricardo's theory was based upon hts understanding of laws of nature-11ke developments in the growth of the population and the conditions of production within agriculture, technical development could not be easily integrated into this theory. Technical change is in a sense an 1 rregular process and as such it contradicts Ricardo"s understanding of economic development as a untversal law-1ike process ${ }^{1}$ ).

The dynamics wthin the capitalist system caused by changes in the ratio of labour to capital goods, only silghtly touched upon by Ricardo, became a central theme in Marx's theory. In his attempt to elaborate upon Ricardo and understand the dynamics of technical change Marx developed his theory of dynamics within the proportional relation of the elements of the so-called organic composition of capital, a subject to which I will briefly return in a following section.

An earlier classlcal economist with whom Marx shared an interest In techntcal change as the development of the process of production and division of labour is Adam Smith. Despite this common interest Marx"s appreciation of Smith was rather limited. Marx described Smith as the political economist par excellence of the perlod of manufacture who "... has not established a single new proposition relating to the division of labour" ${ }^{2)}$. Desplte these and similar cruel remarks Smith is still generally accepted as the classical polftical economist whose work on the division of labour has been pathbreaking *

It is well-known that it was Smith's major objective to analyze the "nature and causes of the wealth of natlons". In this analysis he developed his main argument in which "... changes in productive technique (are) built around the division of labour, both in production and in soclety as a whole. The division of labour depended on the extent of the market, and the extent of the market depended in turn on the accumulation of stock ${ }^{3}$ ). Smith defined this diviston of labour in such a broad sense that it became identical to

1) See K. van der Pol, Marx contra R1cardo, 1981, pp. 96, 97.

2) K. Marx, Capita1 I, $1983(1867)$, p. 329.

3) G. Claeys and P. Kerr, 1981, P. 251. 
technical progress. It referred to both speclalization within a particular factory and spectalization of companies as single product-Iine fltws. Both aspects of the division of labour were seen as important factors influenclng economic growth. He also underlined the relation between technical progress, embodied in new machines, and the division of labour. In Smith"s theory extensive attention was paid to the interrelatedness of technical change, divtsion of labour, the grouth of production, competition and the rale of large production faclities ${ }^{1}$ ). Unemployment caused by technical progress was largely neglected in Smith"s economfcs. He assumed that new techniques were blased toward capltal-saving. It was acknowledged that in a period of economic growth laboursaving techniques were introduced but these were thought to be primarlly introduced to enlarge production whdle retalining the former level of employment. So, within a general economic equilibrum negative employment effects of technlcal change are, accordIng to Smith, 'smoothened' by a macro-economic growth of demand. As mentloned before, Marx was very critical of Smlth's theory of the diviaion of labour as a central initiating factor of economic development. According to Marx, Smith neglected the particular historical and economic setting of capitalist society and its relation to the division of labour. Marx also stressed the importance of the division of labour to the production of commodities and economic growth, but he dented the causal relationship between them as is found in Smith"s theory ${ }^{2}$. As far as Marx reflected Smith's theoretical statements on technical change he was in particular addressing Stith's analysis of the manufacture and the division of labour in the narrow sense.

Apart from the critical perception of classical political economIcs Marx"s theory of Industrlal development and the origin of modern industry has also, to a large extent, been influenced by the

1) See A. Smith, The wealth of nations, 1985 (1776) and for a summary e.g. M. Dobb. Theorles of value and distribution since Adam Smith, Ideology and economic theory, 1981 (1973), H.W. de Jong. Dynamische markttheorle, 1981 , PP. $40-42$ and $M$. Blaug,
$1983(1962)$.

2) See e.8. K. Marx, 1983 (1867), p. 49. 
work of contemporary wrlters on technical development such as Babbage and Ure. In Capital and other publications one has to notice Marx's thorough study and understanding of technological development at a level of detail and in-depth knowledge which probably no economist, Including Schumpeter, has been able to meet since. Marx apparently studied a large number of publications on the history of technical change and new developments of technology and science 10 his time $e^{1)}$. Those reflectlons, despite their possible shortcomings, made Marx one of the first economists to understand the 1mportance of the growing interaction between technical and scientific knowledge leading to technology as an important feature of modern capitalism.

Schumpeter's work, like that of Marx, covers a wide body of interrelated fields of soctal sciences including economics, economic history, socfology and political sclence. And like Marx, Schumeter presented his maln arguments quite elusory as general laws, exceptions and the wider context are discussed shortly after each other, reflecting his continuous struggle with complexity. In the particular field of schumpeter's theory to which I will pay attention - his contribution to industrial economics and the theory of Innovation - some influences of other economists are worth mentioning.

In Schumpeter's early economic theory, as e.g. latd down in his Theory of Economic Development, the economic system was pictured as a 'circular flow' in which the system would be in a stationary situation with an equilibrium under conditions of perfect comper1tion. Some detalls of this model will be dealt with below, but here it will suffice to point at $1 \mathrm{ts}$ theoretical background. It $1 \mathrm{~s}$ 1 mortant to note that the circular flow 1 s not 1dentical with the stationary state in classical political economics. In particular Smlth, Rlcardo and Mill had developed, albeft quite different,

1) See K. Marx's, 1983 (1867), In particular Ch. XV and K. Marx, Die technologisch-h1storlschen Excerpte, 1981 and Excerpte tiber Arbe1tstellung, Maschinerle und Industrie, 1982 in which Marx's excerpts on Babbage, Ure, Poppe and others have been published. 
theorles of statlonary state as the far or nearby "ultimate" destiny of the economy ${ }^{1)}$. Contrary to classical theories the stationary state in Schumpeter's clrcular flow 18 far from any ultimate destiny of the economy. Schumpeter's theory of the circular flow is in fact a particular treatment of Walras" theory of general equillbrium applied to contrast and explain economic development after a change in exlsting routines took place through innovation. It has been generally accepted that the Influence by Walras on schumpeter has been declsive in partlcular on Schumpeter's early writings on economic developinent and innovation ${ }^{2)}$. This influence by Walras gives Schumpeter a certain neo-classical flavour. However Schumpeter"s theory is clearly of a non-neo-classical character as price taking and an infinite number of small companies are not relevant. Even the characterization of Schumpeter as a 'non-neo-classical generall equiltbrium theorist' becomes doubtful In the light of Schumpeter's later works ${ }^{3}$.

The Influence of the Austrian School on Schumpeter has been moderate In the sense that the latter can by no means be seen as a representative of the Austrlans, Schumpeter shared their subjectwe theory of value and critlcism of the classical labour theory of value but the Influence of Walras $1 \mathrm{~s}$ much more dominant. Schumpeter"s theory of a zero rate of interest due to the absence of systematic time preference $1 \mathrm{~s}$ an example of his deviation of the Austrians Inspired by Won Böhm-Bawerk's theory of interest ${ }^{4}$ ). Schumpeter's attent1on to the role of the entrepreneur can be seen In a longstanding tradition of economists. In Schumpeter's (early) theory, the entrepreneur can be described as the change-agent in the clicular flow. Clessical economlots such as Smith, Ricardo and also Marx did not pay too much attention to the role of entrepreneurs as a distinct factor in their analysis. Schumpeter"s Ideas on the role of entrepreneurs had been influenced by a different

1) See e.g. M. Dobb, 1981 (1973), passim.

2) See e.g. A. Smlthies, Memorlal: Joseph Alolis Schumpeter, 18831950, in: S.E. Harris (ed.), 1951 and R.V. Clemence and F.S. Doody, The Schumpeterian system. 1966.

3) See J.A. Kregel, Is the invisible hand a "Falacy of composition'? - Smith, Marx, Schumpeter and Keynes as economic or thodoxy $1 \mathrm{n}$. Cahters d'Economle Pollt Ique, no. $10-11,1985, \mathrm{p}, 48$.

4) See I.A. Schumpeter, History of economic analysis, 1986 (1954), passtm, for his appraisal of the Austrian School. 
tradition with a wide vartety of economists like Marshall, Hicksel, Clark, Bentham, the Austrians, Say, Walras, and early French economists ${ }^{\text {). }}$.

Apart from Walras, one theorist stands out as having had a mafor Influence on Schumeter's work. At first sight one might not expect Marx to be this theorlst who would influence schumpeter, an economist in the marginalist tradition, to such an extent. Let there be no misunderstanding, there are many differences between Marx and Schumpeter, but they also reached quite similar conclustons e.g. on the future of capttalism albelt from an opposite line of reasoning and conflicting analyses. Here th to point at (close-)similarities in their theories on industrial evolution, the importance of technological development, monopoly and extra-profits and industrial concentration.

Schumpeter stressed the success of capitalism which would lead to a future of capltalism in which the economic and 1deological role of the entrepreneur would become obsolece. Contrary to Marx, Schumpeter prophesized that capitalism would suffer from its success. He did not deny soclal inequalities, allenation, cyclical crises or unemployment but these dysfunctions are set against the overall economic "success" of capltallam and unlike Marx they were not seen as causes of the "decomposition" of capitalism". The differences and simllarities between Marx and schumpeter wil be discussed at greater length in the following sections. Here I w11 only Indicate some facets of schumpeter's theoretical relationship to Marx. To understand Schumpeter's interest in Marx it is probably more accurate to think of the latter as sehumpeter" intellectual 'sparring partner" 3). In discugsing Marx as a soclologist Schumpeter's crlticlsm has been remarkably moderate

1) See J.A. Schumpeter, Economic theory and entrepreneurlcal history, in: Change and the entrepreneur, Postulates and patterns for entrepreneurlcal history, $1949, \mathrm{p}, 64 \mathrm{ff} ., \mathrm{P}$. Johnson, New firms, an economic perspective, 1986 and L.V.A. Marco, Entrepreneur et Innovation: les sources francalses de Joseph Schumpeter, in: Economies et socfetês, Vol. 19, no. 10, 1985 in particular the latter stresses the nuances in the 'French connection " of Schumpeter regarding the role of entrepreneurs.

2) See e.g. J.E. Elllott, 1980, p. $54 \mathrm{ff}$.

3) This role is most clear in J.A. Schumpeter, Cap1talism, soclal$18 m$ and democracy, 1975 (1942). 
dewonetrating an lmost neo-Marxist relnterpretation of Marx's '1aws of economic history' as also found In contributions by e.g. Gramsc1 and the Frankfuter Schule. In that context Schumpeter presented an interesting modification of the mechanistic interpretation of Marx's theory of the dlalectic relation between the wel1-know base and superstructure incorporating more camplex relat lons between classes and subclasses 1 . Also, Marx"s economic theory was valued as ".. the only genulnely evolutionary economic theory that the period (of classical economic theory, J.H.) produced ${ }^{2}$ ).

Despite the admiration for Marx's economic writings, which one senses throughout schumpeter's works, he has been very critical about particular elements of Marx"s theory. Schumpeter was very negative about the labour theory of value as an economic theory ${ }^{3}$ ). It would take too long to discuss the issue as such but is clear that Schumpeter was well famllar with the "weak spots" In this theory as a theory of value and price, the law of the tendency of the rate of proflt to fall and the explanation of so-called primitive accumulation. He apparently could find nore apprectation for Marx's theory of the dynamics of accumulation and innovation although he emphastzed that Marx 1... had no adequate theory of the enterprise and his fallure to distinguish the entrepreneur from the capitalist ..." 4 ).

Also Marx's theory of Industrial concentration and centralization was generally accepted by schumpeter. This theory has some sim1larltles with Schumpeter's although the latter stated that Marx's contrlbution overemphasized the stze of Individual companies and was unable to theorlze both monopoly and ollgopoly ${ }^{5}$. This criticlsm by schumpeter is somewhat puzaling and can be seen as a case of 'the pot calling the kettle black'. As w111 be demonstrated be10w, Marx's treatment of monopoly (and olfgopoly. for that matter) 1: essentlally quite 1dentical to Schumpeter's theory. For both monopoly, in particular long-run monopoly, is an exceptional case of Industrial organization and not in the core of the fr theory.

1) See J.A. Schumpeter, $1975(1942)$, pp. 9-20.

2) J.A. Schumpeter, $1986(1954), \mathrm{P}, 441$.

3) See 1dem, passim and J.A. Schumpeter, 1975 (1942), p. 23 ff.

4) 1dem, $1975(1942)$, P. 32 .

5) See 1dem, pp. 33,34 . 
So far for a first impression of Marx's and Schumpeter's theory. Detalls of both theorles relevant for the understanding of current Industrial economics and technology will be dealt with more specifically below. Here it is important to stress that Marx and Schumpeter pald extensive attention to the dynamics of economic change and technologlcal development.

Differences between the classlcal polltical economists and Marx can probably be explained from differences in historical and materlal background. 'Grosso modo' the model of classical pol1t1cal economics was based upon an understanding of manufacture in the early perfod of the industrial revolution. The manufacture was an economic system with a rather conservative character with respect to the nature of production and industrial organization. Contrary to the classical economists Marx bullt his theory upon his understanding of changes caused by the industrial revolution. The rlse of modern industry led towards a more 'dynamic model' of economic development ${ }^{1)}$. The dynamic aspects of Marx"s political economics made him, to quote Heertje, "... the first econonist to realize fully the significance of technical change for economics and society. In particular, he realized the significance of the invention and application of new machines for the diviaton of labour, large-scale production, the creation of new products, and the phenowena of concentration and centralization"2).

Then, if Marx was the first economist to understand the dynamics of technical change, it should be stressed that Schumpeter played an equa11y fmportant role in pointing at the importance of innovation to economic development, changing market structures and the role of large companles in modern capitallsm.

1) See P.M. Sweezy, Modern capitalism and other essays, 1972, p. 139 .

2) A. Heertfe, 1977, p. 61. 
Marx and schumeter both presented economic theorles in which technologlcal development plays a central role. In both theorles technologlcal development vas introduced to explain economic development as an economle evolutlon. In Marx's theory there is clearly wuch concern about the consequences of technological development for the labour-process in general. Marx paid extensive attention to the soclal and economlc consequences of process innovatlons which led him to formulate the so-called law of the average rate of profit to fall. In developing thls theory Marx had some notion of business cycles but it was schumpeter who became one of the most prominent economists theorizing business cycles and technological development. In Schumpeter's theory of economic and technologlcal development we can observe that, compared to Marx, much more attention was pald to the positive economic effects of both product and process innovations on economic development.

\section{Accunulat1on, economic erlses and technology In Marx}

In order to achileve some understanding of Marx's theory of technology and economic development two central concepts of his labour theory of value - surplus value and accumulation - will have to be explalied very briefly flrst.

In Marxist economles surplus value, defined as the increment of the exchange value of labour value over the use value of labour power, can be divided into absolute and relative surplus value. The flrst is generated by a lengthentng of the working day and techntcal development plays no role in the increase of this absolute urplus value. In the creation of relative surplus value, through the 'curtallment of necessary labour time' technical change 1 s predoulinant ${ }^{1)}$. Mechanlzation, which Marx observed as a

1) See K. Marx, Cap1tal I, $1983(1867)$, p. 477 . 
major technical trend in the 19 th century, plays an important role in enlarging the relative surplus value through an increase of labour productivity and the intensiflcation of labour.

Surplus value is increased if the share of necessary labour diminishes, In other words if the value of wage-commodities falls. This particular value will drop if the soclally necesaary labour time to produce commodities used for the reproduction of labour power $1 \mathrm{~s}$ reduced by meams of an increase in labour productivity. It w11 be clear that in that case the growth of labour productivity in the sector producing wage-commoditles is compulsory.

In Marxlst theory this process of surplus value creation is closely related to accumulation, which is characteristic for a capitalist economy. Marx explained the relevance of accumulation to capitalism by pointing at a comparison of so-called "simple reproduction" and "reproduction on an extended scale'.

In the case of simple reproduction Marx pictured a capltalist economic system which is characterized by a lack of dynamics due to so-called atationary clrculation. In short, the yearly value of constant capital applied in the wage-commodities producing sector equals the value of commodities necessary for the reproduction of labour-power in the capital goods producling sector plus a revenue for luxury consumption by capitalists. Or, to phrase it in an other way, In the case of simple reproduction the total surplus value equals the revenues of 'private' capitalist income. There is no economic growth, all net incone 1 consumed and net investment 1s zero'. Marx's description of almple reproduction is a theoretical construct to compare and explain the dynamic character of the capitalist economic system under conditions of reproduction on an extended scale. (As will be demonstrated below schumpeter applied a somewhat simliar method by Introducing his concept of circular flow).

Reproduction on an extended scale is characterized by accumulation because surplus value is converted into extra capttal, the realized surplus value is as it were largely "driven back" Into compantes.

1) See also P. Sylos-Labini, The forces of econoulc growth and decline, 1984, p. 38. 
Through this increaged capttal a capltallst, or a company, is able to appoprlete extra surplus value again. The individual company can enlarge 1ts share in the total surplus value and speed up accumulation of 1 ts capital by increasing the relative surplus value. Mechanization of production processes enables companies which apply advanced means and methode of production to galn a temporary extra-proflt. Competition plays a stimulating role in achleving these extr-profits first. Marx has phrased the relation between accumulation and competituon follows:"... the development of capitallet production makes it constantly mecessary to keep Increasing the amount of the capital laid out in a given Industrfal undertaking, and competition makes the immanent laws of capltaliat production to be felt by each Individual capitalist, as external coercive laws. It compels him to keep constantly extending his capttal, in order to preserve $1 \mathrm{t}$, but extend it he cannot except by means of progressive accumulation"1). In other words accumilation is both the driving force and the cork which keeps the system "afloat" 2 .

Based upon this set of basic ldeas and elaborating upon Rficardo Marx made well-known attempt to explain the consequences of technical development and accumulation in terms of economic crlises. In this theory technical development, and gradually also technologleal development, has to be understood primartly in terms of the growing 1mportance of mechanization.

As such Marx"s theory of economic crises goes beyond the horizon of this study. However, even in a very brlef discussion of Marx's central theorles on economic and technological development one can demonstrate some of his basic Ideas on these 1ssues.

In this theory, which caused a continuing debate between (neo-) Marxiste, (neo-) Ricardians and the like, Marx developed his vision on the substitution of so-called living labour by so-called past labour, or the subst1tution of workers by machines, as an

1) K. Marx, Cap1ta1 I, 1983 (1867), p. 555.

2) In Marx famous work: "Accumulate, accumulate! That 18 Moses and the prophets!", see 1 dem, P. 558 . 
Important consequence of mechanization. Marx defined this deve1opment as the change in the technical composition of capital. This technical composition of capital is determined by ".. the relation between the mass of the means of production employed, on the one hand, and the means of labour necessary for their employment on the other ${ }^{1)}$. In terms of value the composition of capital is determined "... by the proportion in which 1 t is divided into constant capital or value of the means of production, and vartable capital or value of labour power, the sum total of wages ${ }^{\text {tit }}$ ). According to Marx there is a "strict correlation' between the technical and value composition of capital. The value composition of capital, as far as it is determined by the technical composition and reflects its changes, is defined as organic composition of capital'. Since Marx considered mechanization to be characterlstic for capltallsm the technical composition of capital consequently rises continuously. Given the strict correlation mentioned above Marx, Ilke Ricardo, presupposed a growling organle compostion of capttal, which reflects the growing labour productivity within capltalism ${ }^{3)}$.

The thesis of the growing organic composition of capital is closely related to Marx's well-known and oft disputed 'law of the tendency of the rate of profit to fall,4). As surplus value is related to profit and the rate of profit is expressed in total invested capital it follows that in Marx's theory the growth of the organic composition of capttal influences the rate of profit negative1 $\mathrm{y}^{5}$.

Marx admits that the effects of the falling rate of proflt can be diminished by counteracting influences such as ${ }^{6)}$;

1) 1dem, p. 574 .

2) 1bidem.

3) See Idem, p. 583 .

4) It is hopeless task to 1 ist all serlous contributions to the debate, but the more valuable contributions are mentioned in well-known textbooks on Marxlst pol1tical economics, see also J.E. Roemer, Continuing controversy on the falling rate of prof1t: flxed capltal and other issues, in: Cambridge Journal of Economics, Vol. 3, no. 4, December 1979, I. Steedman et al.." The value controversy, 1981 and $B$. Rowthorn and D.J. Harris, The organic composition of capital and capltaliat development, In: S. Resnick and $R$. Wolff, 1985.

5) R. Marx, Capital III, $1977(1894)$, p. 213.

6) See 1dem, pp. 232-240. 
- an Inereasing intensity of exploftation leading towards an Increase of the rate of surplus;

- the depresalon of wages below the value of labour power;

- the cheapening of elements of constant capital;

- relative overpopulation whlch limits the speed of mechanisation due to low wages:

- fore1ga trade by which Imports can reduce the value of constant cap1tal and export comoditles can, If exported to lower labour productivity countries, be sold above thelr value leading to higher rates of profits.

In my opinton thlo enumeration of counteracting Influences by Marx has been somewhat arbitrary. The most relevant counteracting influence from the perspective of technological development is the cheapening of elements of constant capital. It is also this deve1opment which in collaboration with growing productivity became the 'Achllles' heel' of Marx"s theory.

If one evaluates Marx"s law of the tendency of the falling rate of proflt, both the emplrical evidence and logical consistency of the law w11 have to be considered. Since the growth of the organic composition of capltal is the central argument of Marx one should be able to flnd indications of a long-term increase of e.g. the capital-output ratio ${ }^{1}$. However, so far only contradicting ev1dence of a long-term (de-) Increase of the capital-output ratio has been found ${ }^{2)}$.

The relevance of this particular issue In Marx"s theory has also been questloned by critlcialng the logical consistency of $1 t$. Without golng Into any detalls from the ongoing debate in polit1 cal economics $1 \mathrm{t}$ wil suffice to mention that:

1) It should be clear that the capital-output ratio can only be interpreted as an Indicator because strictly taken the capitaloutput ratio 18 formulated in terms of market prices and the organte composition of capital in terms of value, see aloo J.B. Foster. The theory of monopoly capttallom, 1986, p. 13 .

2) See e.g.A. Reat 1, The rate of proftt and the organic compos1tion of capital in West Geman Industry from 1960 to 1981 , M.J. Webber and D.L. Rigby. The rate of profit in Canadian manufacturlng, 1950-1981, and A. Lipletz, Behind the crisis: The exhaustion of a regime of accumulation, in: Review of Radical Polltical Econonics, Vol. 18, no. 1 \& $2,1986$. 
- Marx presupposed a very strlct correlation between the technical and organic composition of capltal, which led him to overlook the differences between physical and value properties.

- If one studies the mar reasons for mechanization in capitalIsm as mentioned by Marx himself there ls little reason to assume a gradual decline of the rate of profit. As Van der Pol has demongtrated the grounds for mechanlzation in Marx's theory can lead to both a decline or a rise of the rate of prof $1 t^{1)}$.

- Technological development in the capltal goods producing sector and the continuous improvement of labour productivity w111 lower value and prices of capital goods ${ }^{2}$.

The issue of a falling rate of profit is not directly related to this study but 1 t reveals Marx"s particular emphasls on mechan1zation, process innovations and 'capital-deepenting' as major aspects of technological development. The resulting debate has had a major Influence on different schools of polltical economics and the present mathematical elegance of the debate w11 ensure the controversy to continue for many decades to come.

\section{Schumpeter on business cycles_and technology}

By contrast schumpeter's theory of technology and economic development had far less theoretical pretentions than Marx's. Schumpeter also expected a decline of capltalism leading to a transition into socialism. However, the major factors at work in this process were thought to be much more related to the growing Importance of large companies and, as a consequence, the obsolete function of the entrepreneur as the social and ldeological 'guard' of capttalism. Technological development in schumpeter's theory 18, as w111 be explained in section 2.5 , also related to the changing role of large companies in modern capitallem. However, I think, 1t would go too far to suggeat a direct relationehip between technologlical development, long lasting gradual economic decline and economic crises in Schumpeter's theory as there is in Marx"s.

1) See K. van der Pol, 1981, Pp. 196-203.

2) See e.g. B. Rowthorn, and D.J. Harris, 1985 . 
Schumpeter's theory of economite developinent and technology, or 1nnovation, 1s most well-known as hls theory of business cycles.

To understand Schumpeter's theory of economic development one has to start of th his model of the circular flow. This circular flow describes a stationary stuation of equllibrium and perfect competition stullar to a Walrasian state of equllibrium. Every fIm is in perfect equilibrium, costs equal income, prices equal average costs and net profits are zero. The clrcular flow follows from continuous adaptions to small external changes which are "absorbed" In famllar routines of company-behaviour. In other words, the economic system is characterized by stability and routine. The model of clrcular flow comes very close to Marx's 'model' af simple reproduction, mentioned above. The main differences between simple reproduction and circular flow appear to be related to the treatment of net profits which are zero in Sichumpeter's model and Schumpeter's abstraction from capitalism in his model. The resemblance of both models becomes more obvious if it is noticed that Schumpeter simply redefined net profits into income assuming that owner-revenues are income and not proftes as in Marx"s theory. The main difference remains in the non-capitalist character of the circular flow, Marx's simple reproduction $1 \mathrm{~s}$ also a case of static equilibrium but there labour is exploited and 1 t has no equal access to capital.

Both models have to be seen as theoretical constructs, ideal types In the "Weberian' sense, or "mental pictures' in Schumpeter's own words. In Schumeter"s theory equilibrium is not so much the central norm or a direct reflection of econonic reality as some authors assume ${ }^{1\rangle}$. Equllibrium is wuch more a slmple theoret1cal norm Introduced to explain the disequilibrium-effects of Innovation ${ }^{2}$. Through Innovation the economic aystem is ariven away from the "nelghbourhood of equilibrium', Then, gradually as the effects of

1) See e.g. A. Smithies, 1951 and W.F, Stolper, Aspects of Schumpeter's theory of evolution, 1n: H. Frlsch, Schumpeterian economics, 1981 , p. 33 .

2) Thls holds only for Schumpeter's treatment of the subject in his early writings. In Capitalism, Soclallsm and Demoeracy, "perfect competition" and 'equilibrium' were no longer applied to explain economic development. 
Innovation "wear off" a mew nelghbourhood of equilibrlun is restored again.

Innovation is introduced Into this model to explain the consequences of discontinual, evolutionary change so characterist tc for dynamic, economlc development. In the clrcular flow schumpeter allowed for economic growth as a continuous stream of amall changes adapting to changes in the "data" of the economic system. Schumpeter explicitly distinguished this economic growth from economilc development as a difference between non-dynamic and dynamic change ${ }^{1)}$. In his own words "... development (...) is (...) entirely forelgm to what may be observed in the circular flow or in the tendency towards equilibrium. It is spontaneaus and discontinuous change in the channels of the flow, disturbance of equilibrium, which forever alters and displaces the equilibrium state previous$1 y$ existing" ${ }^{2}$. This introduction of innovation as a disequilibrium force is the primary cause of cyclical movements of a twophase cycle of prosperity and recession and a new equilibrium in Schumpeter"s pure model.

Like Marx"s theory of economic crises the theory of business cycles is not a subject of this study as such. Therefore only some brlef remarks are made to picture Schumpeter's theory of business cycles. Schumpeter's analysis of business cycles stands out in a tradition of economlc theorists like Splethoff, Robertson, Hansen and also Marx in an earlier period. In Marx's theory business cycles were referred to in many comments. However, Marx unlike Schumpeter, had no theory of business cycles as such, but as the latter tated "... the phenomenon stood clearly before his eyes and he understood much of 1 te mechantsm"3). In Marx's theory of economic development business cycles have to be seen as a cyclical movement of a falling rate of proflt due to a stagnating rate of accumulation within the more general tendency of the average rate of profit to fall.

1) Schumpeter himself did not favour the term dynamics too much, see J.A. Schumpeter. The theory of economlc development, 1980 (1934), p. 64 .

2) Idem.

3) J.A. Schumpeter, 1942 (1975), P. 41. 
Schumpter" theory of business cycles $1 \mathrm{~s}$ apparent in many of his witings, ever in his 'early' vorks, but it is most extensively, athough not so convententy, treated in his, over 1000 pages Iong, study on the subfect ${ }^{1)}$. The Schumpeterian model of business cycles actually exlsts of a franework of a multi-cycle scheme. At the outset there is the somcalled 'flirs approximation" of the pure model of a two phases cycle with a phase of prospertity moving away from equilibrim and a period of recesion moving toward $A$ new nelghbourhood of equillbrlum. The pure model starts off with the clrcular flow which is disrupted by an innowation, financed not by avings but by bank-credit. Innovating firms are able to achleve extra galns which are refnvested and spur a growing demand for (capttal) goods, which in turn w11 lead to a rise in prices for capteal goods. Gradually, the Innovators are followed by inttators 1 in process of diffusion. The entrepreneurs w11 cause sone deflation by repaying their bankloans but meanwile diffusion still increases output. Prlces 111 tend to fall due to the Increasing output and defiation which will cause a change from prosperity tnto recession.

The so-called "second approximation" of the secondary wave can be seen as a more empirical construct to be added to the pure model. Here, assuptions of the ctrcular flow such as perfect competition and equilibrium are dropped. The secondary wave comes down to a four-phase-cycle of prospertty, recession, depression and recovery. It includes economic reactions to the first wave such as a spreading of additional income and speculative operations and mlacalculations of compantes. Growlng output leads to a decline in prices which together wth excess capacity and miscalculations w11 create economic 10 sses and period of recession. A continuing recession leads to a depresston, whlch wears off in a process of liquidation after which remaining compantes find mew economic opportuntties.

1) Idem, Business Cycles, 1939. Fortunately, there are many helpful sumbarles of schumpeter's theory of business cycles, e.g. R.V. Clemence and F.S. Doody, 1966, P. Sylos-Labin1, 1984, A.H. Hansen, Schumpeter's contribution to business cycle theory, in: S.E. Harris (ed.), 1951 and R. Fels (ed.), Abridged edttion of Schumpeter"s Business Cycles, 1964. 
In the end Schumpeter's theory of business cycles leads to 'third approximation' in a multi-cycle scheme of three cycles of different lengths: Kondratleff cycles of \pm 55 years, medium term Juglar cycles of \pm 9 years and \pm 40 months kitchin cycles. It is relevant to note that innovation and diffusion are important in Schumpeter's theory of business cycles as they create a 'bandwagon effect of Imitators following the inftial innovators. Furthermore, the creation of new Industries based upon very important Innovations such as rallways, electriclty and automobiles are to be understood as the orlgins of the long-term cyclical movement of the economy.

From the above it is clear that the aspects of both Marx"s and Schumpeter"s theorles of technologlcal and economic development discussed above are of a fairly macro-economic nature. To a certain extent this linits the relevance of these particular aspects for this study. However, in both theories much attention is pald to technology as an important factor in economic development and as such they provide a useful background for understanding those elements of Marx's and Schumpeter's theorles which are more related to Industrial economics.

From the foregoing it is clear that technological development in Marx's theory was restricted to understanding socio-economic consequences of mechanlzation. Marx's theory led towards a theory of economic crises based upon a law of the falling rate of profit. If anything is clear with respect to this theory, 1t $1 \mathrm{~s}$ Marx's exphasis on the labour-saving, capital augmenting character of technologlcal development. Marx dit not deny the relevance of reverse options as such, but he clearly emphasized one side of the coln. Consequently Marx formulated a theory of technlcal change and economic development in which the need for accumilation, aupported by the possibilities of exploiting new technologies, would in the long run lead to economic decline and recurring economic crises. Neither Marx nor Schumeter were too optimistic about the future of cap1tal1sm, although both stressed, In somewhat different ways, the achlevements of capitalist soclety. The mall cause for the uncertain future of capital1sw in Schumpeter's theory had 11ttle to 
do wh thechnological development as such; in his theory the forces of decline are in principle related to ldeological and social consequences of the obsolete role of entrepreneurs. Schumeter's general theory of economic development and technical change did emphasize the importance of business cycles for understanding long-term economic development. Most relevant lissues in Sehumpeter"s theory of businesi cycles for the present study are ralated to the importance of major Innovations with their 'bandwagon' effects on the Industrial structure and disequilibrium effect of technological change.

2.4 MARX AND SCHUMPETER ON TECHNOLOGY AND INNOVATION

So far, no attention was devoted to Marx"s and Schumpeter's conceptualizations of technology. In the foregolng concepts such as technology, technical change and innovation are merely treated as synonyms. In a strict sense this is not correct as each of these concepts, although clearly related to each other, refer to different aspects of the same process of changing or creating products and processes. In this section 1 will comment on Marx"s and Schumpeter's understanding of technlcal change itself. Both paid extensive attention to this complex subject and the complexity is reflected: In their struggle to conceptualize and operationalize their understanding of both organizational and technical aspects of this core-element of their theory. In both theories technical change as such is not explained unambiguously. Marx made an attempt to explatn techndcal change within a systematic explanation of the 'laws of htatory'. Schumpeter was definitely less ambitlous but even this restricted attempt to conceptualize technical change In the context of markets and company-behaviour has left some guestions unansered with a clear need for further clarification.

\section{Marx on the forces of product 1on and technology}

Each at tempt to understand Marx's theoretical exposition of technical development w111 have to go back to bastc concepts such as 'productive forces' and "relattons of production'. Marx's conceptualization of technical development can be placed under the 
baslc category of productive forces. He applied the concept of productive forces as a synonym for means of production, but also In a wider context where the concept was applied to indicate the "Intercourse of man with nature". In that wider comtext the concept of forces of production refers not only to concrete means of production, but also to technique, scilence and the organization of the production process ${ }^{1)}$. Marx's concept of productive forces has to be seen in the light of his thoughts about the growing abllity of human belngs to control nature. In order to control nature it is not only technique which is applied extensivelly, but also particular soctal relations which are established to organize this contro $1^{2)}$. Production relations, or 'formations of soclal intercourse" in Marx's earlier works, refer to the soclal organization of the interaction of human beings and nature. Therefore production relations are more than just relations of property, they also comprise relations of (groups) of workers and relations between capitalists.

In this context the oft disputed issue of technological determinism in Marx"s theory can be raised. In a simple construct technological development can be seen ws the most lmportant element in the development of productive facces as they determine the production relations thereby acting as the 'motor of history' ${ }^{3)}$. The popular view of Marx as a technical or technological determinist is frequently 'proved" by pointing at an oft quoted passage in which he writes: "In the social production of their existence, men Inevitably enter into definite relations, which are Independent of their w11, namely relations of production appropritate to a glven atage in the development of their material forces of production. The totality of these relations of production constitutes the economic structure of society, the real foundation, on which arises a legal and political superstructure and to which correspond def1nite forms of social consciousness (...). At a certalin stage of development, the material productive forces of soclety come into

1) See e.8. K. Marx and F. Engels, 1982, passim, and K. Korsch, Kar1 Marx, 1972, pp. 167-171.

2) See K. van der Pol, 1981, pp. 121, 122 .

3) See M. Pleterson (ed.), Het technisch labyrint, 1981, p. 126. 
confilct with the exlsting relations of production (....). Frou forms of development of the praductive forces these relations turn into thelr fetters. Then begins an era of soclal revolution. The changes in the economic foundation lead sooner or later to the transformation of the whole immense superstructure"1). A somewhat similar "example" of technological determinlsm fs found in a passage where Matx states that "... soclal relations are closely bound up wth productive forces. In acquiring new productive forces men change this mode of production; and in changing their mode of production, in changing the way of earning their living, they change all thelr soclal relations. The hand-mill gives you soclety with the feudal lord; the steam-n111, society with the Industrial cap1tal1st" ${ }^{2}$ ).

The lssue of technical determinism in Marx's analysis led to a long lasting debate and much 'close reading' and few fruitful contributions. An exception is found in Rosenberg's contribution where one learns that 1 in Marx there is 11ttle evidence of techn1cal progress as an lindependent vartable in explaining soctal development. Rosenberg explatng that in several passages in the Communtst Manifesto, the Grundrisse and Capttal one will find anything but determinlsm on technology. Rosemberg, in my opinton, properly states that the essence of Marx's view is that "... the elass struggle, the basic moving force of history, 1s 1tself the product of fundamental contradictions between the forces of production and the relations of production. At any point in historical time, new productive forces emerge, not exogeneously or as sone mystertous deus ex machina, but rather as a dalectical outcome of a largex historlcal process in which both the earlier forces and relations of production play essential roles" ${ }^{3}$ ).

By referting to assage from the Communtst Manlfesto Rosenberg demonstrates that Marx (and Engela) descrlbe how the discovery of Amertea and other colontes resulted in an expansion of demend, and

1) K. Harx, Critique of pol1tical econony, 1971, pp. 20-21.

2) K. Marx. The poverty of philosophy. $1973(1847)$, p. 95 .

3) N. Rosenberg, Marx as a student of technology. in: Monthy Review, 1976, no. 3 , p. 60, reprinted in: Inside the black box: technology and economics, 1982, p. 38. 
how such a growth of the market caused a change from the gullds, through the manufacture, to modern industry. Technical change which played a part in this development is not described as a prime mover by Marx but is much more seen as a derivative of growing markets and needs ${ }^{1)}$. Also, the analysis of the orlgin of the manufacture in Capteal I provides little evidence of any sort of technological determinism. Marx explained how the manufactures differ from the old gullds at first only by the larger number of workers in each unit of production. Then he continued to describe how changing relations of production gradually leads towards a new form of division of labour in which technical development is characterized by a 'differentiation of the instruments of labour ${ }^{2}$ ). So, in the analysis of the orlgin of manufacture Marx described a change of relations of production within which the methods of production did not change at flrst. Then, influenced by the changes of relations of production, there has been a gradual. change in techniques.

The 1ssue of technological determinism by Marx is relevant in the light of modern, evolutionary, contributions and the analytical framework which w11 be discussed in chapter 4. There 1 t will be demonstrated that technological development and company behaviour can be analyzed as changes within or changes of so-called technological paradigms. Within technological paradigms heuristics will lead to basic designs or technological guide posts. These bastc designs do not follow deterministically from a given set of technological possibilities. In industrial technology a selection environment of compantes, labour relations and the technologlea 1 communty selects particular options. Once a particular design has become dominant trajectorles almed at technological improventents will follow pre-determined lines of development unt11 technological opportunities have been explofted or changes in the selection environment have created other technological options.

1) Ibidem, pp. 59-60 (1982, pp. 37, 38); K. Marx and F. Engels, Communistisch Manifest, 1968 (1872), pp. 41-42 (Dutch edition).

2) See K. Marx, 1973 (1867), Pp. 317-347. 
It Is in that context that Marx's dialectical relation between forces of production and production relations lis quice ldentical to an analysis based upon the dlalectlcal relation between technologlcal paradigms and bastc deslgns, and a selection environmert.

If Marx was not technological determinlst one can st111 wonder whether he did show some technological optimiam. In a sense Marx was a technologlcal optimist stressing the importance of science and technology for modern Industry as 11 'resolved" the old manufacture based economlic system. Marx described the 'revolutionary' character of modern Industry, 1ts continuous change of technology and 1 ts far reachlng potentlals for modernizing the entire economy. Taken out of 1 ts context Marx well-known grandlloquent language in the descrtption of the revolutionary character of modern Industry can easily be misinterpreted. However, placed within its context we see that Marx continued to describe the other side of the coln, the soctal and economic consequences of modern industry to the working class ${ }^{1}$. These social and economlic consequences were thoroughly understood by Marx as can be seen from his great emphasis on understanding technologlical development itself. All this is clearly shown in his analysis of developments of the manufacture, the changed application of machinery and the growth of modern industry. In a particular section of Capltal Marx presented an analysts of a process in which changes in the social organization of the labour process and the development of the productive force gradually introduced transition of the economic structure of control from gullds to co-operation to manufacture to f lnatly modern tndustry. In this development, which took place in a relatively short pertod, there had been an Industrial revolution In the continuous mechanization of production. This industrial revolution was ituated by Marx in the transition from mamucture to modern 1ndustry. A particular feature of this transition from the technical perspective is the substitution of handicraft by

1) See A.g. K. Marx $1973(1867)$, PP. 456-457. 
machine-related labour ${ }^{1)}$. Such a process of mechanlization which began within certain sectors of industry lead to a chain-reaction with further mechanization in various other sectors of industry. Marx placed emphasis on the role that mechanization of the machine producing sector played in the general mechanization process. If the machine producing sector would finally have been mechanized the manufacture 1tself became completely outlived because that particular stage even the handicraft-production of machines would be replaced by modern industry ${ }^{2}$ ). (In a historical comparison this situation is analogous to modern developments in manufacturing whereby robots are bullding robots, and the clrcle of automated manufacturing is closed.)

In analyzing the empirics of mechanization Marx mentioned several consequences of this development such as:

- a further division of labour which involves intensifying the labour process;

- the expulston of 'redundant' workers and the origin and growth of an industrial proletariat;

- the expansion of employment of women and children;

- the growing importance of scientific knowledge to the labour process within modern industry.

The diffusion of mechanization throughout manufacturing led to Marx to formulate his already mentioned alternative political economics in an attempt to assess the far-reaching consequences of the Industrial revolution. It w11, however, not be necessary to point at the weakness of this attempt once again. It is more relevant to Indicate Marx's success in understand1ng the role of industrial technology and advanced methods of manufacturing in his

1) In this context Heertje mentions the change "... from equipping the men to manning the equipment", A. Heertje, 1977, p. 41, 'Manning the equipment' can be seen as an 'unfortunate' cholce of words; Marx and others have demonstrated that in this particular era of Industrialization child and woman-labour was frequently misused at an extremely large scale, see $K$. Marx, $1973(1867)$, pp. 372-380.

2) See K. Marx, 1973 (1867), P. 363; see also N. Rosenberg, 1976, p. $66(1982$, P. 44$)$. 
time. With this 1n-depth knowledge of not only economic but also techntcal and sclentific aspects of the major trends in manufacturing he was well ahead of his contemporaries. It enabled Marx to present a powerful economlc analysis of the most pervasive technologlcal paradigm of the 19 th century.

\section{Innovat1on and new comb Inat 1ons}

In the above I have already stated that Schumpeter was less ambitlous in developing his theory of economic development than Marx who attempted to understand soclal development in all its facets In a 'closed system'. But like in Marx"s writings technological development, or more appropriate innovation, played an important role In Schumpeter's economic theory from his early publications to those writings which have been published posthumously. Unlike Marx, who studled technology itself in great detall, Schumpeter appeared satisfied with less understanding of technological development 1tself. This attitude becomes most clear in the distinction Schumpeter made between invention and innovation. For understandIng the economic Impact of technology Schumpeter separated the process of Invention as an exogenous factor frati the endogenous character of Innovation. One could state that Schumpeter was not Interested in understanding technological development unless it entered Into the sphere of circulation or market exchanges ${ }^{1)}$. However the picture becomes somewhat more complicated if notice is made of ahift in schumpeter's theory of innovation from an early interpretation in a model of largely entrepreneurlal lnnovation to a model of large firm managed Innovation where technological knowledge Including Invention becomes endogenous to large compantes ${ }^{2}$. In his early works, Schumpeter introduced the concept of Innovation to explain the change-over from routinized economic growth In the clicular flow to economic development through the carrying

1) See e.g. J.A. Schumpeter, 1939, p. $84 \mathrm{ff}$.

2) See also C. Freeman, J. Clark and L. Soete, Unemployment and technical tnnovation, 1982, pp. 38-43, A. Philips, Technology and marketstructure, 1971 , E.S. Mason, Schumpeter on monopoly and the large f1rm, In: S.E. Harris (ed.), 1951 and $N$. Rosenberg, 1986, p. 211 . 
out of new combinations; The description of tinnovation as carrying out new combinations has been given lin most of the 11 terature on Schumpeter; here, the original text will be reproduced to demonstrate the 'width' of his concept as:

"... (1) The introduction of a new good - that 18 one with which consumers are not yet famlliar - or a new quality of a good.

(2) The introduction of a new method of production, that is one not yet tested by experience in the branche of manufacture concerned, which need by no means be founded upon a discovery sclentifically new, and can also exist in a new way of handing a comodity comercially.

(3) The opening of a new market, that is a market into which the particular branche of manufacture of the country in question has not previously entered, whether or not this market has existed before.

(4) The conquest of a new source of supply of raw materlals or half-manufactured goods, again irrespectlve of whether this source already exists or whether it has first to be created.

(5) The carrying out of the new organisation of any industry, like the creation of a monopoly position (for example through trustification) or the breaking up of a monopoly position ${ }^{\text {int }}$ ).

Compared to e.g. Marx's concept of forces of production Schumpeter's concept seems to be more of an operational character. Nevertheless, it is still very broad since it encompasses both technical change, diversification and a change in elements of the market structure. Innovation in the Schumpeterlan sense deals with new products and processes, product differentiation, new markets, diversification, new raw materials and new market structures. Furthermore, these new combinations will be carried out by new companles replacing the older ones. Howevex, Schumpeter also noted that In modern capitalism large companies become more and more Important

1) J.A. Schumpeter, 1980 (1934), p. 66, and also 1939, pp. 84-86. 
as Innovators. The difference in the role of the 1nnovating new company and the growing Importance of 'great combines' In stimulating Innovation was seen by schumpeter as ".. the water-shed between two epochs in the soclal history of capitalism"i).

Throughout most of his writings Schumpeter referred to innovation as new combinations, but in some publications he also defined it "... as the setting up of a new production function" ${ }^{2}$ ). Whether this reference to production functions was helpful is in my op inIon doubtful. As Heertje recal1s, Schumpeter introduced different definitions of production functions such as:

a. "(...) the given technological possibilities within the horlzon of producers;

b. (...) blue prints, where every element that is technologically varlable at all can be changed at will without any expense;

c. (...) a 'realistic' production function, to be constructed on the basis of factual obserwations of production and factors of production, distinct from the 'loglcally pure' production function" 3 ).

All definftions of Innovation given by Schumpeter whether related to new combinations or production functions are clearly rather broad and vague. It is obvlous that all this reflects his difficulty in 'struggling' with the complexities of technologlical development .

It should not be a surprise that Schumpeter's attempt to define Innovation has been critlictzed by many authors. These criticisms of his deftnittons range from 'fuzzy' and too brasd on one extreme to too narrow, as it only relates to new firms and new entrepreneurs, on the other ${ }^{4)}$. The latter crittolsm "cuts no lce" if we

1) J.A. Schumpeter, $1980(1934)$, p. 67 .

2) $1 \mathrm{dem}, 1939, \mathrm{p} .87$, see also 1986 (1954), p. 1026-1053.

3) A. Heertje, 1977, p. 100; see also J.A. Schumpeter, 1986 (1954), p. 679, p. 1031 and p. 1031, 1032, for each of these definftions of production functions.

4) See R.V. Clemence and F.S. Doody, 1966, pp. 39-50 for an overview of criticisms. 
consider Schumpeter's description of innowation in the broader context of his subsequent writings. The crittelsm might appear to have some relevance to his concept of innovation in the Theory of Economic Development where he referred to the role of new firms as innovators. Although, as mentioned before, even there schumpeter explicitely referred to that role in so-called 'competitive capltalism" and not to the later stages of capitalist development. In his subsequent publications large, exlsting, companies became more Important as innovators in modern 'trustified' capitalist. So, In general schumpeter referred not only to new compantes as the main source of innovation.

The objection against the broad character of Schumpeter"s definition is to be taken more serlously. In that context one can critIclze both the production function and the new comblinations sort of approach. A well-known criticism of Schumpeter's definition of innovation as the setting up of a new production function has been made by Lange. Lange argued that there is always a large number, even a possible infinite number, of ways of changing existing production functions. Relevant are only those changes which w111 lead to an increase in the maximum effective profit ${ }^{1)}$. But then Lange proposed in a sense to understand the 1ssue prectsely the way Schumpeter apparantly meant to avold. The latter stressed that his definition is not "... equivalent with 'change in method" or 'change in technique' of production"2). In ather words Schumpeter's definition of innovation did not refer to a shift along but a shift of the production function itself. Lange is clearly mistaken in assuming the avallibilicy of an almost infintte number of changes of production functions. As will be discussed at greater length in some following chapters, technology does not refer to Infinite set of options and solutions to technical problems. In practice these options are limited in general and even more $11 \mathrm{mited}$ to Individual companles.

Nevertheless, I think that Schumpeter's reference to new production functions as an 1llustration of Innovation was a bad cholce.

1) See 0. Lange, A mote on Innovations, In: Review of Economics and Statistics, Vol, 25, February 1943, p. 21.

2) J.A. Schumpeter, 1939, p. 87 . 
Whatever the benefits of production functions for ecomomic analyBis may be, it $1 \mathrm{~s}$ not a concept which has been very successful in both explaining or understanding the eharacter of technical change In process Innovations, let alone product finnovations. Furthermore, Schumpeter's definitions of production functions are somewhat vague compared to more generally accepted definitions, which only adds to the confuston in attempting to understand Innovations as new production functions.

As mentloned before, also schumpeter" definition of Inmovation as new combinatlons $1 \mathrm{~s}$ also very broad as it relates to technical, market and organtzational aspects of the subject. All three aspect are important for understanding the complexity of Innovation. However, it could be useful to distinguish between then. A prelininary qualification can be made by 'narrowing' the concept in abstracting from organfzational and market structure related elements. Then, innovation would be limited to new goods or an improvement of the quality of a good, new or Improved methods of production, in other words, product and process innovations. These 'technical' Innovations have to separated from organizational Innowation and changes in the market structure, although it is obvlous that they are related and influence one another.

Another issue which needs some clarification is the role that minor technolaglcal changes played in schumpeter's theory of innovation. It is clear that schumpeter frequently referred to Innovations as more or less radical changes with a great impact on sectors of Industry and business cycles. Minor day-to-day technfcal Improvements are apparently less important. In particular in the Theory of Economic Development technical changes based upon exliting routines was seen as irrelevant. However, in Capltalisw, Soclalism and Democracy routinized Innovation becomes an Important factor in the role large companies play, but the lisue as such is not discussed thoroughly. In that sense, Schumpeter's concept of Innovation 18 also too restricted as tt abstracts form the subsequent steps of technical improvement once an Innovation has been 
introduced. Therefore modern theortes of technological dewelopment including learning by using and/or doing are relevent supplementaries to schumpeter's theory ${ }^{1)}$.

Both theories, Marx"s and Schumpeter"s, were early contributions to the social scientists" attempt to conceptualize technological development. No matter which successes have been made in analyzing the effect of technology on economic development since then, the conceptualization itself has been troublesome ever since. The conceptualizations by Marx and Schumpeter provide some useful elements which w11 be elaborated upon in chapter 4. Here, it w111 suffice to notice that:

Both Marx and Schumpeter paid attention to the social and economic environment of a technical change. Marx saw technical change in the context of dialectical relationship between the forces of production and production relations. Process innovations (mechanization) were theorized with respect to their consequences to the labour process in general and their relation to both class struggle and competition as inter-capitalist rivalry. Although product innovation was recognized as relevant to economic development, Marx pald relatively little attention to it.

In Schumpeter one observes that both process, and product innovation are stressed as important aspects of technical change, which Is certainly a 'gain' compared to Marx. However, Marx"s theory is of greater use in its conceptual distinction between technical development as such and its economic environment. Schumpeter's definition of innovation including technical, market structure and organizational aspects has made the concept too broad.

Also in another respect Marx's conceptualization 18 superlor to Schumpeter's. Schumpeter paid I1ttle atention to technology 1tself, as it was seen as an exogenous factor unt1l it becaute endogenous as an Innovation. In some of his later work Schumpeter did pay more attention to technological development as an endogenous factor in the development of larger, sclence-based, compantes. In

1) See e.g. N. Rosenberg, Inside the black box: techmology and economics, 1982, P. 120-140. 
Marx, attention to technolog1cal development has been wore expllicit throughout his theory. He has made serfous attempts to understand technology, as the application of sclentiflc knowledge to techn1cal development, in 1ts relation to soclo-economic development. In that sense Marx's conceptualization of technological development is close to a theory in whlch an attempt is made to understand Innovation, In a narrow sense, as an element of technological development which is influenced by a selection environment.

2.5 COMPETITION, DIFFERENTIATION OF COMPANIES AND TECHNOLOGICAL DEVELOPMENT

As th1s study of Marx and Schumpeter proceeds to their contributions to industrial economics and innovation theory the $1 \mathrm{r}$ theories show more and more convergence. Many differences rema1n, but on Issues such as competition, monopoly, concentration, large companies and corporations the differences are not as fundamental as Schumpeter himself apparently wanted us to belleve. Even a major source of theoretical distinction - Schumpeter"s emphasis on the critical role of the entrepreneur to economic development - is qualified in favour of the role of large corporations in his later writings to such an extent that the "gap' between Marx and Schumpeter is not as large as it appears at first.

\section{Compet tion, monopoly_and technical change}

Marx's theory of competition has to be understood in the context of the classical economic theory and his own theory of accumulation. In clasical economic theory competition, profits and pricedetermination were related to each other in a way which is quite different from for example present neo-classical economic theory. In Marx's theory, but also in Smith"s and in Ricardo"s, demand and supply played but a mincr role in price determination although they were thought to have a function as a sigalling mechanion for changes in the Industrial structure. In classical political economics and In Marx's theory price determination has to be seen in the $11 \mathrm{ght}$ of the concept of "centre of gravity". Smith had chosen 
the "natural price' composed of the normal wage, normal rent and normal proflt as rewards for production factors, as the centre of gravity'. The market price, the actual trading price, could af course devlate from the natural price ${ }^{1)}$. In Smith's theory the natural price is a sort of guide-post for competition ${ }^{2)}$. For Marx and Ricardo the value of present labour and past labour Incorporated In capital goods, which are both applied in production, form the bas1s for the 'centre of gravity'. So, production prices form the "centres of gravity" for market prices. Competition and numerous other "accidental' circumstances such as denand and supply, speculation and temporary monopolles determine the transient changes in market prices ${ }^{3)}$. Competition amongst companies is aimed at achfeving temporary extra profits in the process of accumulation.

For Marx competition is but a derivative of the process of accumulation, manlfestation of $1 t$. Competition has, according to Marx, no impact on the essential features of capitalism ${ }^{4}$. Marx saw competition above all as the result of the development of companies. Competition does not only refer to market relations, the circulation of comodities, but also to the production, realisation and distribution of surplus value. The role of competition in the production of surplus value is in particular related to the capttalist"s propensity to increase labour productivity through which a transient extra surplus can be realized by those firms which apply the most advanced methods of production at first.

1) See A. Smith, 1985 (1776), pp. 160, 161 .

2) See e.g. H.W. de Jong, 1981, p. 36, J. Eatwe11, Competition, In: I. Bradley and M. Howard, 1982, and P.L. Williams, Monopoly and centralization in Marx, In: Hiatory of Political Economy, Vol. 14 , no. 2,1982 .

3) See 0 . Demele and W. Semmler, Konkurrenz und Monopol, In: Idem Monopoltheorle, Kontravers, 1980, p. 13, and W. Semiler, Competition, monopoly and differential proftit rates, 1984.

4) See e.g. '... scientific analysis of competition to not possible before we have a conception of the Inner nature of capital...", K. Karx, 1973 (1867), P. 300, and 1detn, Grundr1sise der Kritik "der politischen Dekonomile, 1974 pp. 637, 638 and 450, see also S. Kuruma, Marx Lexikon zur politischen Oekonomie, Konkurrenz, 1973 for an overview of all relevant passages In Marx. 
Wthin the circulation of surplus walue marketshares of companies and differences in condittons of realization are deterinined by competition. The distribution of total surplus value is determined by the intersectoral competition of companies which, according to Marx, w11 lead to long-run tendency of equal rates of proftt in a11 sectors ${ }^{1)}$.

Closely related to Marx's theory of accumulation and competition 1 h his explanation of the development of compantes or separate units of capltal. This refers to the discourse on concentration, centralization and differentiation as different momenta of capital1st development ${ }^{2}$. The nature of the relation of each of these subject in thelr dealings with competition and accumulation differs to some extent. Differentiation and concentration are concepts which can be explained by the following quotation of Marx's own explanation of concentration: "With the Increasing mass of wealth which functions as capltal, accumulation increases the concentration of that wealth in the hands of Individual capital$18 t s(. .$.$) . The growth of soctal capltal is effected by the growth$ of many Individual capitals, and with them the concentration of the means of production, Increase in such proportion as they form allquot parts of the total soclal capital (...). With the accumulation of capltal, therefore, the number of capltalists grows to a greater or less extent ${ }^{3)}$. Marx continued with remarking that concentration is actually identical to accumulation and characterized by two features. "First: The increasing concentration of the soclal means of production in the hands of Individual capitalists 18, other things remaining equal, 11mited by the degree of inerease of soclal wealth. Second: The part of soclal capttal domictled In each particular sphere of production is divided among many captialists who face one another as Independent commodity producers competing with each other" 4 ).

1) See also W. Semler, Competition, monopoly and differentials of proflt rates; theoretical considerations and emp1rica1 ev1dence, In: Revlew of Radical Political Economics, Vo1. 13, no. 4. Winter $1982, \mathrm{p}, 41$, and W. Semler, 1984.

2) See H.W. de Jong, $1981, \mathrm{pp}, 50-51$, and $\mathrm{K}$. Kuhne, Economics and marx1sm, 2 Volumes, 1979, pp. 267-278.

3) K. Marx, $1973(1867)$, pp. 585-586.

4) $1 \mathrm{dem}, \mathrm{p} .586$. 
Differentiation, the growth of the number of Individual capltals, and concentration are in this manner limited by the growth-rate of the process of accumulation. On the other hand, centrallzation takes place more or less independently of accumulation and 1 s therefore much more a stimulus for accumulation. Marx has distingulshed centralization from concentration as follows: "This process differs from the former (concentration, $J H$ ) in this, that it only pre-supposes a change in the distribution of capital already to hand, and functioning; its fleld of action is therefore not limited by the absolute growth of social wealth, by the absolute Imits of accumulation. Capital grows in one place to huge mass in a single hand, because it has in another place been lost by many"1). In other words, Marx's definition of centralization $1 \mathrm{~s}$ Identical to what modern economics somewhat confusingly refers to as aggregate concentration. Competition amangst companies determines the speed and the range of the process of centralization. Companies which have not been able to sell their comodities, usually at the lowest prices, w111 be taken over or w111 remain as sma11 companies in certaln sectors of industry where centralization has not yet taken place. Centralization in 1 ts turn stimulates accumulation of capital. "The means of capital fused together overnight by centralization reproduce and multiply as the others do, only more rapldly, thereby becoming new and powerful levers in soctal accumulation. Therefore, when we speak of the progress of social accumulation we tactrly include - today - the effects of centralization"2) "This growth of large combined capltals offers, according to Marx, a base for further development of "sctentiflcally arranged processes of production".

Centralization played thus a central role in Marx"s theory. The development of foint-stock compantes and the Increased Importance of the credit syotem are extra stimull for thls process of centralization. In the end centralization could reach the 'theoret1cal' upper limits in a particular sector if "... all the Individual capitals invested in 1 t were fused into a single capital. In a

1) Ibidem.

2) 1dew, p. 588 . 
given soclety the limit would be reached only when the entire social capital was united in the hands of either a single capital1st or a single capitalist company"l). Such remarks which can also be found at other places 1 in Marx's analysis, have contributed to the development of Marxist theor1es of monopoly based upon speciflc interpretations of Marx's discourse on centralization.

Marx himself however pald relatively little attention to monopoly. Monopol1st1c pricing, as explained above, was seen by Karx as an Incldent which causes a deviation of the market price from the production price. Such a monopoly was termed 'Inctdental monopoly" "... which a buyer or seller acquires through an accidental state of supply and demand" 2 ). All other references made to monopoly by Marx are also discussed as deviations. Coments on monopoly, trusts and cartels have been added to the original text by Enge $18^{3)}$.

More than monopolization 1t seems Important to note that in Marx's theory disequilibrium effects of competition and accumulation are reflected in concentration and centralization, or Internal and external growth of compantes, and even the posstble growth of the number of compantes.

Schumpeter"s 1deas on competition are not fundamentally different. He did assume perfect competition and equilibrium in the model of circular flow, but these assumptions were dropped in the extended madel of the second approximation which allowed for innovation. There, Innovation introduces imperfect competition and disequilibrium Into the economic system. The introduction of innovation renders entrepreneurlal profit to early introducers. This entrepreneurlal profit has to be understood as a surplus over cost ${ }^{4}$. The

1) 1dem, pp. 587,588 .

2) K. Marx, 1977 (1894), p. 178.

3) See e.g. 1dem, p. 120 and Pp. 437,438 .

4) It has to be stressed that Schumpeter constders the Income of management and company-owners as wages or costs and not as profits, see J.A. Schumeter, 1980 (1934), p. 128. 
diffusion of an Innovation gradually destroys the surplus of entrepreneurlal profit in a process of "progressive diminution". The entrepreneurial proflt, extra proflt in Marx's terms, disappears when the Innovation becomes part of the clrcular flow agaln and price and costs are in a normal relation again ${ }^{1}$.

Like Marx, Schumpeter pald but little attention to monopoly as such. In his early writings, In particular in the Theory of Economic Development, it is excluded from the circular flow; although as Chamberlin mentioned it could have been Introduced wthout changing the static character of the mode1 ${ }^{2}$. Once innovation is introduced it has a disequilibrium effect wh short-term monopoly revenue unt1l diffusion restores a nelghbourhood of equilibrium agaln. So innovation is in a sense related to monopoly. In Schumpeter's own words: "Since the entrepreneur has no competitors when the new products first appear, the determination of their price proceeds wholly, or within certain limits, according to the principles of monopoly price. Thus there is a monopoly element in profit in a capitalist economy ${ }^{* 3}$ ).

In Capltalism, Sociallsm and Democracy Schumeter's treatment of monopoly has to be seen in the light of the well-known process of 'creative destruction'. This creative destruction pictures the truly dynamic and evolutionary character of capitalism. Capltalism is seen as "... by nature a form or method of economic change (... which...) not only never is but never can be stationary" ${ }^{4)}$. Schumpeter stressed the dynamic element in competition related to Innovation which goes further than price competition or quality competition or competition in sales efforts because this form of competition stems from new commoditles, new technologies and new forms of industrial organlation. Economic change is induced by these new combinations which lead to creative destruction as a process of destroylng and reshapling of older into new industrial structures. In that context Schumpeter emphasized that economic

1) See 1dem, p. 136

2) See E.H. Chamberlin, The Impact of recent monopoly theory on the Schumpeterian system, In S.E. Harris (ed.), 1951.

3) See J.A. Schumpeter, $1980(1934)$, p. 152.

4) 1dem, $1975(1942)$, p. 82 . 
analyels should not study Industral structures as such, but concentrate upon the investigation of the creation of new and the destruction of exlsting structures and the role of competition, monopoly and company behavlour in this process.

Monopoly, both short and long-run, $1 \mathrm{~s}$ theorized by Schumpeter as an element in the process of creative destruction, as the latter sets theoretical 11mte to monopollstic behaviour. Short-run monopoly $1 \mathrm{~s}$ accepted as a necessity for innovation and technologIcal development. Mason correctly stated that "... the essence of Schumpeter's position is that market power is necessary to Innovation and that innovation is the core of effective competition" 1 ). The wel1-known classic Cournot-kershall theory of monopoly is $1 \mathrm{r}-$ relevant to Schumpeter's theory. If the strict Cournot-Marshall condition of flxed demand for a monopolist 1 set aside short-run monopoly can be integrated Into Schumpeter"s model. Then InnovatIon has some features of monopoly but a new combination st111 has to compete with existing products and demand for it is not given. However, lasting, long-run monopoly w111 be a rare accasion, according to Schumpeter. The process of creative destruction changes existing structures and new industries are created whlch surpass exlsting industrial, structures including monopoly.

In that sense competition and monopoly were not so much opposites In Schumpeter's theory but much more two sides of the same coin.

The above demonstrates that in both Marx's and Schumpeter's theory monopoly, In the sense of long-run monopoly, is considered to be of 11ttle relevance to the analysis of economic structures. Economic change, accumulation and competition 18 wuch more relevant to both analyses. Marx"s theory allows for a diatinction of companies 1nto larger and smaller companies within the process of accumulatiom. The main differences between Marx's and Schumpeter"s theory of the subject are related to changing industrial atructures and to certain extent to the centralization of companies.

1) E.S. Mason, 1951, p. 89. 
Schumpeter made a valuable contribution in stressing the relevance of creative destruction to understanding the evolution of industrial structures, a subject to which Marx pald little atention. Marx stressed the importance of centralization, or Industrial concentration in modern economic theory, for economic and technological development. As w111 be demonstrated below schumpeter pald less attention to the Issue in his early writings, but it galned much more attention in later publications.

\section{Entrepreneurs, new_companies and large corporations}

In modern Innovation theory, of which I will address some issues in chapters 3 and 4 , much attention $1 \mathrm{~s}$ pald to the role played by entrepreneurs, new companies and companies of different sizes. Both Marx and Schumpeter had something to say about the role of each of these 'actors'. Having discussed Marx's theory of central1zation it will not be a surprise that in his theory the emphasis has been on the role of large companles. But Marx also mentioned new compantes, to which he referred as additional capttals, as creators of innovations in particular in their role of "incubators' of process Innovations. These new compantes would serve as an example to existing companies. In the long-run, older companies were expected to develop efther into a more "perfected technical form' or gradually disappear under competitive pressures ${ }^{1)}$. Compared to Marx's thoughts on the 'example-setting' relevance of new companies, the role of entrepreneurs was less relevant to his theory:

Like Schumpeter Marx understood the difference between Invention and Innovation and the different roles inventors and entrepreneurs play. However, both Inventors and entrepreneur recelve relatively Iftcle attention in hls theory. As Rosenberg has remarked "... for Marx Invention and innovation, no less than any other socto-economlc activitles, were best analyzed as soclal processes rather than Inspired flashes of Individual genlus. The focus of Marx's discussion of technological change is thus not upon individuals,

1) See K. Marx, 1973 (1867), PP. 588, 589. 
however herolc, but upon a collectlue, soclal process in which the inatitutional and economic environment piay major roles ${ }^{\text {it }}$.

The $11 \mathrm{~m}$ ted role Individual Inventors played according to Marx is clearly demonstrated by his remark that "... critical history of technology would show how little any of the inventions of the 18th century are the work of angle individual ${ }^{2)}$.

An equal qualification was dedlcated to entrepreneurs. In Marx's theory the dynamles of economic development, technical development Included, is not a prime result of entrepreneurial activities. For Marx there is no real difference between the entrepreneur and the capltalist the former only galned his interest as a capitalist. From a schumpeterian perspective 1t seems accurate to state that Marx made no clear distinction ${ }^{3)}$. However such a distinction would have been Inconatisent wth Marx's own theory. In Marx's perception of capitalist soclety economic dynamics regult from a process of accumulation which 1 s based upon the contradiction between capltal and labour. The efforts of an lndividual capltalist to Introduce process or product Innovation become only of some 1mportance to Marx if this development, through a process of diffuston, surpasses the level of pure Incidents.

Marx did understand that the orfglinal innovators, troubled with high Inttial costs, could frequently make but $11 t t l e$ benefit of thelr efforts. In that context Marx has comented, in his wel1known somewhat exaggerated wording, on "... the far greater cost of operating an establishment based on a new invention as compared to later establishments arising ex suls ossibus. Th1s is so very true that the trall-blazers generally go bankrupt, and only those who later buy the bulldings, machinery etc., at a cheaper price, make money out of $1 \mathrm{t}$. It $1 \mathrm{~s}$, therefore, generally the most worthlese and milerable sort of money-capitallets wo draw the greatest profit of all new developments of the unlversal labour of the human eptrit and thelr soclal application through comblned Labour" ${ }^{4}$ ).

1) See N. Rosenberg, 1976, pp. 57 and 70 (1982, P. 35 and 48).

2) See K. Marx, $1973(1867)$, p. 352.

3) See A.C. Taymans, Marx"s theory of the entrepreneur, in: The American Journal of Economics and Soctology, 1951, p. 83, J.A. Schumpeter, 1975 (1942), p. 32. .

4) See K. Marx, 1977 (1894). 
Schumpeter"s theory of the role of entrepreneurs and also his definition of entrepreneurship reveals what is probably the most striking difference with Marx. But also in schumpeter" own theoretical development there is a gradual but clear change in the role entrepreneurs play. As mentioned before his theory of capltalist and technological development can be categorized into two periods: a period of entrepreneurlal capltalism and a period of modern, trustified capltalism. The distinction, frequentiy made in the 11terature, is useful and acceptable as long as it 'admits' that Schumpeter pafd attention to both entrepreneurlal and large company activity in capitalist soclety. The distinction could be Interpreted in terms of different points of emphasis and not so much as a dichotamy 1 ).

Schumpeter presented his theory of capltalist development of the entrepreneurial era, whlch probably colncided with the 19th century, most clearly in his Theory of Economle Development. There, entrepreneurial activity was seen as a third factor of production, next to labour and land. In the explanation of the circular flow land and labour are set in equal terms. Labour, however, is differentiated in directing, creative labour of a higher order and directed labour. Differences between ocher categories of labour such as productive and unproductive labour, direct and indirect labour, mental and manual labour or sk11led and unskilled labour are all neglected as irrelevant to Schumpeter"s economic analysis. The decisive element of directing, creative labour is embodied in the entrepreneur. The entrepreneur was defined as the Individual who carries out new combinations. In a sense the entrepreneur is the personification of inmovation. It la important for understandIng Schumpeter's definition to note that the entrepreneur can be both an Independent entrepreneur or an employee of a large company with an entrepreneurlal function ${ }^{2)}$. A major difference with Marx' s

1) See also F. Chesnals, Schumpeterlan recovery and the Schumpeterian perspective - Some unsettled lsaues and alternative interpretations, in: H. Glersch (ed.), Emerging technologles: Consequencles for economic growth, structural change, and employment, 1982, p.63.

2) See J.A. Schumpeter, $1975(1942)$, pp. 74, 75. 
thoughts on the entrepreneur as a capitalist is that entrepreneurs are by definftion nelther inventors, capltalists or a social class. In practice all three can be combined in one person but definitely not necescar11y so ${ }^{1)}$. In my optnion Elliot is mistaken 1n stating that "... successful entrepreneurs 'become' capitalists In Schumpeter's analysis" 2). According to Schumpeter succesful entrepreneurs might become capltalists but they stop being entrepreneurs once they fall to continue to innovate and (re-)return to captialist routines.

In this early version of Schumpeter's theory capitalists are owners of companies which malntain their existing routines and bankers who provide credit to the entrepreneur. The role of credit for innovative investments is also one of the key differences with Marx"s theory in which credit is merely seen as a function in the process of centralization ${ }^{3)}$. In Schumpieter's system innovations are introduced by entrepreneurs and financed through bank-credit and not savings. Credit is essentlal to economic development as a change from the clrcular flow. It enables the potential entrepreneur to actually become one and, as 'the typical debtor of capitalist society" to reorgandze the existing combinations ${ }^{4}$. In stressing the role of the entrepreneur as Innovator and debtor Schumpeter presents a defintion of the entrepreneur in which risk-taking is less essentlal as in other well-known theorles, in particular those in the tradition of Say and Knight ${ }^{5)}$.

1) E.g. Thirtle and Ruttan are mistaken if they understand Schumpeter"s entrepreneur as inventor, see C.C. Thirtle and V.W. Ruttan, The role of demand and supply in the generation and diffuston of technical change, 1987, p. 3 .

2) J.E. Elliott, Schumpeter and the theory of capitalist economic development, In: Journal of Economic Behavior and Organization, Vol. 4, no. 4 , 1983 , pi 286.

3) See e.g. R. Belloflore, Marx after Schumpecer, in: Capttal and Class, no 24, Winter 1985.

4) See J.A. Schumpeter, $1980(1934)$, p. 95 ff.

5) See e.B. L.V.A. Marco, 1986, p. 104. 
In Schumpeter the entrepreneur is the true and only economically relevant change-agent of a pre-trustifled capltalist soclety. Elster has characterized Schumpeter"s entrepreneur as both a rational and irrational motivated agent. The entrepreneur's behaviour "... Is rational in the sense of successfully exploiting the objective possibilities of innovation, yet irrational in that he is ridden by a demon who never lets him be satisfled by results"1).

For understanding Schumpeter's perception of modern capltalism the later version of his theory of the firm is more appropriate. In Captalism, Socialism and Democracy Schumpeter plctured the diminishing Importance of the entrepreneur who loses his function as the agent who changes existing routines. Economic development gradually becomes 'depersonalized" and "automatized". Consequently, "... Innovation is being reduced to routine. Technological process is increasingly becoming the business of trained special1sts who turn out what is required and make it work in predictable ways $^{\prime 2}$ ). This routinization does not only take place in large companies but it is clear that Schumpeter also acknowledged the growing importance of incremental technological change pursued by these large companies. In one of his last and relatively unknown publications Schumpeter returned to the subject of routinized Innovation in large companies. There the role of entrepreneurial activity is stressed again but now in the importance of co-operative entrepreneurship in large companies. Somewhat surprisingly Schumpeter even mentioned the possible role of entrepreneurlal change-agent for other organizations than compantles, e.g. the role of state agencies ${ }^{3)}$.

1) J. Elster, Explaining technical change, 1983, p. 120.

2) See J.A. Schumpeter, 1975 (1942), p. 132.

3) See J.A. Schumpeter, Economic theory and entrepreneurfal history, $1949, \mathrm{p} .71$, where the role of atate agencles such as the US Department of Agriculture is discussed. As a side step I would like to point at the political economic consequences of this attention for creative labour other than the single person entrepreneurlal activity known from Schumpeter"s early writ1ngs. If entrepreneurial activity has become co-operative action instead of the 'herolc' creative labour of a ingle entrepreneur $1 t$ can also be a form of combined creativity of others than just management. 
The dlsappearance of the entrepreneur as the only change-agent in capltallam has far reaching consequences. Schumpeter, I1ke Weber, stressed that rationalization and bureaucratization had become major trends in modern capttalist soclety ${ }^{1}$. The final consequences of these features of modern capitalism is that, according to Schumpeter, 1t evolves towards soclallst soclety as the "bourgeofile" 111 lose 1 ts soctal and 1deological defender. The issue as stch goes beyond the alms of this study but an often quoted and clartfying passage can reveil much of Schumpeter's far reaching. conclustons. There 1t is stated that, "... If capltalist evolution - 'progress' - elther ceases or becomes completely automat1c, the economic basts of the Industrlal bourgeolste w11l be reduced eventually to wages such as are pald for current administrative work excepting remants of quasi-rents and monopolold gains that may be expected to linger on for some time. Since capltalist enterprise, by 1ts very achlevements, tends to automize progress, we conclude that 1 tends to make 1 tself superfluous - to break to pleces under the pressure of 1 ts own success. The perfectly bureaucratlzed giant Industrial unit not only ousts the small or mediumsized firm and 'expropriates' its owners, but in the end it also ousts the entrepreneur and expropriates the bourgeolste as a class which in the process stands to lose not only its income but also what is infinitely more important, its function" 2 ).

For the study of Industrial economies it is relevant to point at the role of large companies which is quite stmilar to their role In Marx's theory. Schumpeter acknowledged that in a world of large companles small companies can play some role. He even stressed that large companies mot only destroy but also create some submarkets for smal1 compantes ${ }^{3)}$. However, as a whole modern cap1tallsmi would, according to schumpeter, gradually become dominated by "blg concerns'.

1) See also J.A. Foster, The polftical economy of Joseph Schumpeter: A theory of capitalist development and decline, In: Studies in Polltical Economy, no. 15, Fal1 1984, pp. 16, 17.

2) J.A. Schumpeter, $1975(1942)$, p. 134 .

3) Idem, p. 140 . 
It is in the analysis of the role of large companies in modern capttalism that one is to observe a high degree of convergence between Harx's and Schumpeter's theory. As mentloned above, both stressed the consequences af Industrial concentration or centralization In Marx's terminology, for technological development and capitalist soclety at large. They also demonstrated a foint bellef in the remaining, albeit petty, role of small companies next to large companies in some market-niches.

Schumpeter"s theory on the role of large corporations in modern capltalism led him to formulate its far reaching consequences for capitalist society in its transition to a socialist econony. In a sense Marx's theory has some similar aspects referring to the declining function of the entrepreneur as a capitalist in capltalist soclety. In one of the, in my oplation, most remarkable and Inconsistent parts of Marx"s theory there is a discourse on centralization and joint-stock companfes. In a short paragraph on the 'historical tendency of capitalist accumulation' 1 t is outlined how the expropriation of capttal will be executed by "... the action of the immanent laws of capitalist production 1tself, by the centralization of capital"1). Marx explained how the number of 'magnates of capital' is constanty reduced by competition, economic crises, and the process of concentration and centralization. This leads towards a critical limit within capitalism as the "... monopoly of capitalism becomes a fetter upon the mode of production, which has sprung up and flourtshed along with, and under 1t. Centralization of the means of production and socialization of labour at last reach a point where they become incompatible with their capitalist integument. Thus integument is burst asunder. The knell of capitallst private property sounds. The expropriators are expropriated" 2 ). Even if one takes into consideration that Marx thought in terms of 'tendencies' if referring to 'laws', and his theory at this point was not well developed, it all remains dubious. Apart from the fundamental criticiom of the deterministic

1) K. Marx, $1973(1867)$, p. 714 .

2) 1dem, p. 715 . 
and mechandstic character of Marx's exposition one can add more detalled criticlsm to his conception of capltallst economic development. Marx presupposed that concentration and centrallzation would lead towards an antithesis of the capltalist mode of production and the exlsting production techniques and organization of productlon. It 18 evident that for many technological developments predominated by large-scale production a certain minimal planta1ze and probably also company-size is Indispensable. Apparently there 1 some relation between concrete forms of centralization and the development of forces of production in those compantes, but 1t is unclear why this should have such far reaching consequences as the transition of capitallst society as a whole into soclallsm.

Marx based himself on the assumption that the development of 19 th century modern production technology and the organdzation of production developed by capitalist compantes themselves would eventually contradict private property of capital.

Marx also presupposed that concentration and centralization occur In all sectors of industry to a simflar extent or these tend to converge to an equal rate across the economy. There are, however, structural differences between branches which leads towards a sectoral differentiation of capital. The growth of large-scale production with but a few companies in some sectors does not imply that this process takes place to an equal degree in ald other sectors. Furthermore, large-scale production does in some cases create favourable conditions for establishing small independent suppliers which can operate along-side large compantes.

The Immanent tendency whtch Marx discussed while analyzing concentration and centralization appears to be the fruit of an exagigerated deterministic interpretation of one aspect of soclal history. In this interpretation concentration and centralization have been 111-expressed as a Iinear and 1rreversible process which would also contradict the nature of the capltalist mode of production ${ }^{1)}$.

1) Similar reservations about these aspects of Marx's theory are found in A. Cutler, B. Hindess, P. Hirst and A. Hussa1n, Marx's Capltal and Capitalism Today, Vol. 1 and 2, 1977 and 1978, p. $148 \mathrm{ff}$. 
Marx expose on the role of corporation and folnt-stock companies has to be seen in the context of the above mentioned. The role of corporations and joint-stock coupanles in Marx's theory is closely related to both competition and the growing importance of credit whlch are described as the two 'most powerful levers of centralIzation 1 . In the above it has already been stressed that accumulation is a slow process compared to centralization; in centralfzation the "economic time" is reduced substantially" . Marx mentioned corporations which have brought about large profects such as in shipbullding, ratlroads and harbours through their financing in a much shorter period than would have been possible in the case of accumulation of distinct capitals ${ }^{3}$.

In Marx's brlef remarks about the cred1t-system the following three developments resulting from the creation of corporations or joint-stock companies were specified:

- "An enormous growth of the scale of production and of enterprises, that was impossible for individual capitals" ${ }^{4}$ )"

- Capital as a corporation would cease to be private capltal and become based upon a 'soclal mode of production'. Marx referred to 'social undertakings' and went as far as to state that such corporations are to be understood as "... the abolition of capital as private property within the framework of capltalist production itself" 5 ).

- Capitalists are separated into two soclal categories: managers, administrators of capital, and capital-owners as money-capitalists. Here Marx showed himself as a radical 'managerial economist avant la lettre'. The Afvorce of ownershlp and management 18, according to Marx, the ultimate development of capitalism and a prerequisite transitional phase into soclalism of assoclated producers. It is worth mentioning that also schumpeter

1) See K. Marx, 1973 (1867), p. 587 .

2) See H.W. de Jong, p. $92 \mathrm{ff}$.

3) See K. Marx, 1973 (1867), p. 588 and 1dem, Cap1tal II, 1977 (1885), p. 481 .

4) K. Marx, 1977 (1894), P. 436 .

5) 1bidem, I think the orfginal German text on this 1 sisu 1 s much more strongly phrased than the Engl1sh translation. 
stressed thls separation of ownershlp from management in large coupanies as important steps in the 'depersonalization" of capital1sm ${ }^{11}$.

Marx understood the corporation as the abolition of the capitalist mode of production wthin capital1sm, 'a self-dissolving contradiction'. which can be descrlbed as phase of social transition. However, it is also noted by Marx in his turged way of phrasing that $\mathbb{1 t}$ "... reproduces a new flnanclal aristocracy, a new variety of parastes in the shape of promotors, speculators and simply nominal directors; a whole sytem of swinding and cheating by means of corporation promotion, stock Issuance, and stock speculation. It 18 private production without the control of private property" $^{2)}$ (e.a. J.H.).

Marx's treatise on the corporate and joint-stock company does 11 lustrate hls understanding of the role corporations play in the process of centralization and the effect of 'tempo profit' due to corporate organtzation of capital. On the other hand Marx's analysis of corporations also demonstrates number of serious shortcomings and fundamental errors. As mentloned before, Marx did not explain why the corporate organization should contradict the capitalist mode of production. The introduction of the predicat 'social. to corporations and the attention paid to the separation of property and management are too easily interpreted as a necessary 'overriding" of the capltalist mode of production. The description of the financilal structure of the corporation, in which an "exaggerated" terminology is applied In order to picture both parasitic relations and fraud, does not capture the essentlal Intertwining of corporate power in present capltalism. I think Cutler et al. are right as they state that "... In his treatment of stock-companies and flnanclal markets Marx reveals his fallure to theorlze the enterprise, rather than the "capitalist", or to concelve of finance capitalist enterprises" ${ }^{3)}$. Marx's analyais of the enterprise as a structural element of the capitallst mode of

1) See J.A. Schumpeter, $1975(1942)$, pp. $141,142$.

2) K. Marx, 1977 (1894), p. 438.

3) Cutler et a1., 1977, p. 154. 
production remains largely limited to 'the' capitalist as '1dealtype". Consequently the change from the classical to the corporate enterprise is overstated as a step towards a soclalist mode of production, instead of stressing 1ts importance as an essential change within capitalism.

From the above it becomes clear that Marx and Schumeter shared many aspects of their views on the role of different categorles of compantes. Even though they had different conceptions of 'the' entrepreneur, the future of either the entrepreneur/capltalist or the entrepreneur/Innovator was foreshadowed in both theories as dim. Both were correct to see a diminishing role of owner-capitalists or owner-entrepreneurs in modern capitalism. But I fail to see why this would lead to a fundamental transition from capitalIsm into social1sm. In that context Schumpeter and, In particular, Marx overemphastzed the change-over to corporate company structures. If both Marx and Schumpeter had paid more attention to their own arguments and analyses of dymamic development in cap1talism thelr theories would not have had that particular 'teleological' character. Without this superfluous part of their theorles the dynamic elements in their analyses are most valuable. Then it is relevant to point at their, albeit somewhat differemt, analyses of the separate roles played by large, powerful compenles, small compantes and/or new firms in a process of accumulation, restructuring and competition.

2.6. DEAD-ENDS AND ROADS TO PURSUE

The issues discussed in the previous sections are those which I percelve as mogt relevant in the $11 \mathrm{ght}$ of what is to follow. Both, Marx and Schumpeter, have dealt throughout thelr work with many 1s gues st111 relevant to modern economics. B.g. 1ssues related to Industrial concentration, size of companies and technologlcal development have been theorized in their work. During the development of their theories changes in emphasis, in particular in Schumpeter's theory, did occur. Such changes provide opportunity for several interpretations of thell work. It is no surprise that 
one flnds severall interpretations of both Marx and Schumpeter in the 11terature. Furthemore, both presented their theorles without the rigour which we have come to know in present industrllal economics. However, the very strict formulations in econowics can Mo redefine complexity in an artificial manner ${ }^{1}$. To a certain extent Karx"s and Schumpter's treatment of technological and economic development reflects both the complexity of the issue 1tself and their struggle in combining theory and empirics.

The fact that Marx and Schumeter have reached simflar or very close conclusions on many toples 1 s at1l somewhat surprising since they came from such different traditions in economic theory. After all, Marx"s theory was, desplte his critlcism, deeply rooted In clasical political economics. Schumpeter, the 'bourgeols' Marx, came from a completely different background and was influenced by the marginalist school. The (close) simflarities and the differences w11 be discussed as far as they lead to conclusions relevant to understanding modern, heterodox, thoughts in industrial economics. In particular starting-points for the study of technological development and industrial change will be disclosed.

A major shortcoming of Marx's theory of economic and technological development, and also a dead-end for innovation theory, is the emphasis Marx laid upon the far-reaching consequences of process Innovations. Technology played an Important role in Marx's theory of the value-composition of capital, elaborating upon classical economic theory, In particular Ricardo. Mechanization, undoubted1y the major technical development in the second half of the eighteenth century, was thearlied by Merx not only in terms of the technical composition of capttal but also in terms of the value-composition. It led Marx to formulate law-14ke theorfes on the organic composition of capital and $a$ tendency of the rate of proflt to fall and consequently to a theory of economic crises. Marx emphastzed the labour-saving character of process innovations and although cap1ta1-saving was not denled, the consequences of $1 \mathrm{t}$

1) The well-known controversy over the so-called schumpeterhypotheses and the modelling and empirical research on that topic provides some examples of simplification, see chapter 3. 
as such played no role in his considerations. The same can be said about the role product innovations played in his theory. Throughout Marx"s works one can find remarks about the relevance of product Innovation, but, unlike in Schumpeter's theory, they are neglected within the general framework.

A positive feature of Marx's theory is hils attempt to understand technology as an endogenous factor. The theoretical framework of the forces of production and relations of production wight be somewhat broad of scope but the dlalectlcal relation between both is important to note. In this theory one can notlice that forces of production and relations of production influence each other constantly. In modern economic 'lingo' the above mentioned categories could be translated into technological development and socio-economic selection envil ronment. Within the soclo-economic enviromment Marx stressed that there is not only a relation between capltal and labour but also one between capltal-to-capital. This leads to an understanding of the economic environment of technological development in terms of a differentiated composition of a group of companies. The notion of the relation between technological development and a socio-economic selection environment is quite identical to Marx"s 1deas on forces of production and production relations. In the context of this study the relation between technology and economic development can, at first, be interpreted in terms of a classical Marxist relationshyp. Then, technological development has a twofold character. In itself it is largely influenced by the posslbilities and restrictions set by laws of nature. The concrete applications of technology is, however, largely influenced by its soclo-economic acceptablitty and cholces made by competing companies. The economic selection environment, relevant to this study, 1s generated by the complextty of producers and users of particular technologies.

Another feature of Marx's theory worth pursulng is his thorough attempt to understand technology, 1.e. the coupling of sclentific knowledge to practical production-related problems. In modern industrlal economic analysis technological development is frequently abstracted from or reduced to simple Indicators. However, the economic study of industrial and technological change could benef1t from more in-depth knowledge of technology as such. 
Although Marx went as far as to formulate lmost his entire theory of economic crises on his understanding of mechanization, it remalins relevant to note that, despite his jumping to conclusions, Marx nevertheless attalned an unprecedented knowledge of technological development. In the above I have already mentioned that Marx' understanding of the process of mechanization during the Industrlal Revolution can be seen as an atempt to understand the consequences of the major new technological paradigm in the 19 th century. His study engaged both scientific sources of technolog1cal development as well as the technical detalls of concrete applications. Modern technological development has, of course, become much more complex and more pervasive than in Marx's time. Integrating knowledge of a technological character into economic studies can, by consequence, only be realized through multi-disciplinary co-operation. Attempts to integrate technological know1edge into those flelds of Industrial economics in which innovation Is studied can enrich the analysis and provlde the necessary background for Interpreting Indicators of technological development.

In this context Schumpeter's conceptualfzation of technological development or Innovation can be discussed. Schumpeter demonstrated some Interest in technological development but he never went as far as Marx to understand technology specifically. In his theory of economic development technology is both an exogenous and an endogenous factor. Sehumpeter was not interested in the 'early' phases, the pre-market developments of technology. In particular in his early writings technology is exogenous and innovation was only theortzed as new combination. In stressing the relevance of large science based companies Schumpeter allowed for technology to becone more endogenous to his theory.

Compared to Marx, Schumpeter came definitely closer to economic reallty stresing the Importance of both product and process innovation. The definition of Innovation 1tself, however, is not too clear. Schumpeter referred to Innovation both in terms of new comblinations and new production functions. The reference made to a shift of production functions $1 \mathrm{~s}$, in my opinion, not very successful as Schumperer defined production functions in several ways and the reference remalned quite 'fuzzy'. The definitlon of innovation 
In terms of new comblnations is also too 'broad, but it can be 'tightened' by separating technical or technolioglcal innovation from soclal Innovations such as changes in market structures and corporate organizations:

Schumpeter's focus on Innovation as a new combination without too much atention for technological development as such did not only result in the abstraction from early phases of technology, it also meant that minor technological changes were neglected. As with the early phases, the Importance of later phases of technologlical development became somewhat more important in Schumpeter's later work.

Both Marx and Schumpeter presented economic theorles of technological development in which the dynamic and evolutionary character was stressed. Marx pald extensive attention to accumulation as dynamic evolutionary economic development in a model of reproduction at an extended scale which was characteristic for modern capitalism. Economic growth, of both Individual companies and the economic system at large, through accumulation is essential in Marx's theory. Within this process of accumulation competition amongst individual compantes regulates the distribution of profits. Extra-profits are gained by those companies which are the first to intraduce new technologies successfully until the effect wears off as other companies beneftt from the gradual diffusion. Some companies will not be able to catch up in time. In a process of gradual decline they w1ll disappear, some w111 be taken-over and some might continue for long periods due to particular circumstances. In general it will be a 'game of winners and losers'. Schumpeter's theory, although differently phrased, is quite similar. In his early theory Walrasian equilibrium is applied in the construct of the circular flow as a theoretical norm. Innovation 18 a change from existing routines. In later veraions of Schumpeter's theory the dynamic character of capitalism and the disequilibrium effects of innovation are stressed even stronger. Throughout his theory Schumpeter pald attention to the profitseeking stimulus for innovation which through diffusion would cause a bandwagon-effect after the first successful introduction. 
The attention pald to evolutionary change, disequilibrium, competition through 1ninovation and the process of diffusion which is to be found in both Marx and Schumpeter has, in my opinfon, most valuable elements for understanding present industrial development.

In Schumpeter one can find a useful elaboration upon Marx"s thoughts on monopoly and the more general 1dea of monopoly and Innovation or technologlcal change. Marx pald little attention to monopoly, which was constdered as an incident, but I suspect that Marx would not abject agalnst Schumpeter"s notion of an element of monopoly in innovation. Both Marx and Schumpeter paid little or no attention to relation between long-run monopoly and innovation. In Schumpeter's earlier writings the entrepreneur is able to gain proftts, extra-profits in Marx's terminology, through the introduction of an innovation. There 18 an element of short-run monopoly or market-power in 1nnovation unt11 this short-run monopoly is destroyed through diffusion. In later versions of his theory Schumpeter introduced the concept of creative destruction. Through creative destruction the dynamic and evolutionary character of capital1sm is exposed in competition with new technologies and new commodities as a process of restructuring older and creating new industrial sectors. Schumpeter's ideas on creative destruction are most valuable as they surpass the notion of static monopoly. Even If there is an element of monopoly in an innovation it still has to compete with existing products and demand for it is not given. The dymamlc character of captralfsm with its continuous restructuring and the creation of new sectors makes long-run monopoly a less relevant notion, only applicable under exceptional c1rcumstances.

Industrial concentration and the dominance of large companies in relation to technological development are frequenty mentioned within Marxist or Schumpeterlan perspectives. It has to be acknowledged that both Marx and Schumpeter provided the arguments themselves, although not always as stralghtforward as the Interpretathons of thelr 'followers'. I would like to broaden the scope again in order to differentlate between several categorles of companies. 
Marx stressed the importance of internal growth of companies. This process was labelled concentration and the speed of this process depended on the process of accumulation. In this process of concentration Marx also saw the appearance of new compentes $H i s$ concept of centralization is of a different order since it is mot accumulation which sets the limits of company-growth. Centrallization is found in the process of mergers and take-overs and $1 \mathrm{~s}$ much more a stimulus to accumulation. Marx also noted the growing Importance of sclence based large companies in centralization.

It has been mentioned before that all this led Marx to see centralization, in combination with the appearance of foint-stock companies, as an important step in the process of a transition to soclalism. I think it is more relevant to go back one step, as it were, and to retain some relevant notions of different categorles of companies which follow from Marx"s theory.

The emphasis Marx latd upon concentration and centralization together with large-scale production made him point at the importance of large companies. In my opintion Marx was right in his analysis of the modern large corporation as a large joint-stock company which is able to stimulate technology by shortening the 'economic time' of innovative profects. Had he pald more attention to sectoral differences in centralization and economies of scale Marx could also have articulated the relevance of smaller companies complementing large companies more adequately. But it has to be acknowledged that Marx apparently did see the 1mportance of new companies, and in particular in their role of rlsk-bearing, early introducers of Innovations.

Schumpeter"s analysis of the role of different categorles of companles resembles Marx's theory to a certain extent. At first Schumpeter stressed the almost heroic role of the entrepreneur as the innovator of caplitalism, but even in his early works be pointed at the particular importance and relevance of this role in nineteenth century capitalism. In a sense Schumpeter's attention for 'the' entrepreneur is as much a simplification of technological or Innovative capabilities of a company as 1s Marx's reduction of the company to "the" capitalist. However. Schumpeter also pointed at the growing importance of entrepreneurship within large 
companies where innovative activitles would come frow joint-effort: In many sectors of industry 1nmovation would gradually be generated by large sclence based companies with formalized RsDdepartments where innovation would become routinized.

These conslderations led Schumpeter, like Marx, to pay almost exclusive attention to the growing role of large, sclence based, corporations. And also like Marix he acknowledged that swaller compantes did continue to play a role in some sectors of industry and In certain market-niches, although the 1ssue was not central to his maln argument. If schumpeter would have regarded his own 1deas on creative destruction more carefully his theory of the firm could have been less deterministic and more differentiated.

Such a differentlated framework of categorles of companies, based upon those d1stinguished by Marx and Schumpeter, would consist of:

- large dominant corporations, frequently science based;

- smaller companies of different sizes which have either found particular diarket-ntches or provide supplementary services to the large dominant companies;

- new companies and cross entry.

All these companies have to be seen In the light of two 1mportant aspects of industrial development:

- competition changes the relative positions of companies over time within each sector of industry;

- In the process of creative destruction sectors of industry are reorgantized and new sectors are created through which the existing market structure and relations are fundamentaliy changed. 
Despite shortcomings and flaws in Marx's and Schumpeter"s theories 1t has become clear that, In my opinfon, both contributions are noteworthy and could st111 have some relevance to the understanding of present capltalist society. In particular in Marx's theory the attention pald to technological change did not only appear in abstraction but Marx developed his theory from a thorough understanding of technology 1tself. With few exceptions, such as e.s. Berna1, most Marxists and neo-Marxists have not followed Marx 1 in this tradition. In particular (neo-) Marxist politicall economists have pald little attention to technological development unless it could be incorporated at a high level of theoretical abstraction. Marx's own understanding of technological development was embedded In this theory of the dialectical relation between productive forces and relations of production of which the latter can be seen as the selection environment of technological development. Within this selection environment it is not only the capltal-labour relation but also intercapitalist rivalry which is important. Technological development plays a cruclal role in competition generating 'winners and losers'. The dynamics of competition become clear in the process of accumulation which generates both concentration and centralization, but also the establishment of new companies. In the analysis of accumulation Marx paid most attention to large companfes and their ability to create large Innovative projects. Other categorles of compantes were mentioned 'In passing' without much attention being pald to them in the central argumentation.

Like Marx, Schumpeter stressed the relation between competitlon, technological change and disequilibrium. In his analysis of so-called trustifled capitalism the role of large sclence based companies as major innovators is emphasized. From the reconstruction of Marx's and Schumpeter's theorles in the previous chapter it follows that in the analysis of industrial development attention should be paid to changes in the competitive environment of 
companies due to the fects of creative destruction. Furtherwore, both Marx and Schumpeter provlde elements of a classification of companies in such categortes as large, frequently sclence based, companies, small and medium sized companies and new companies.

In the following sections two central themes w1ll be addressed:

F1rst, the Implications of Marx's and Schumpeter"s theorles w111 be studied for the so-called neo-Marxist contributions to industrial economics and the so-called schumpeter controversy regarding market structure, firm size and innovation. The attention paid to the role of large companles in both Marx's and Schumpeter's theorles have led many ecomomists, Influenced by these theories, to draw direct 11nkages from monopoly to technologlcal development. As explained above the original contributions hardly led to such conclustons. Long run monopoly is not connected to innovation in e1ther theory. Short run monopoly is relevant but then monopoly: Is seen as a translent feature of early introduction.

In section 3.2 ome neo-Marxist contributions to the analysis of cap1tallst and corporate development w11 be subject to a critical assessment. It fia followed by two sections in which the so-called Schumpeter-controversy over the relation between firm size, industIfal concentration and Innovation, a major theme In the past decades of Industrial economics, will be discussed.

The second theme of this chapter covers an elaboration upon contributions in which Innovation is analysed in the context of different categorles of companies according to slze and organization. This categorization of compantes w111 be complemented by a brief discussion of the relevancy of understanding corporate strategies In terms of (changes of) routines and alternative strategles. This enables me to stress the necessary dynamic aspects of the relation between Industry atructure and Innovation if corporate strategles. are taken into consideration.

Both central themes provide waterlals for analysing an induatrial sector and technological development. At the end of this chapter I w11 be able to establish such a framework in which the complexities of different categortes of compantes, innovation strategles and technologtcal opportunity are taken Into account. It has to be 
seen as a necessary Improvement of orthodox Marxian and Schumpeterlan analytical tools. It also serves as an analytical setting for the analysis of technologleal change and the economic analysis of a concrete sector of industry in the two following chapters of this study.

MEO-MARXIST THEORIES OF COMPETITION, DIFFERENTIATION OF COMPANIES AND TECENOLOGY

If one has decided to search for new Insights in so-called neoMarxist theorles one appears bound to dig through a vast "plle" of Marxist literature in which 'Capital' is explained and re-explained. According to e.g. Mishra and Braverman 11ttle attention has been pald to the further understanding of technological development within the Marxist traditon ${ }^{1)}$. There are not too many contributions which go beyond 'Marxology' and in particular empirical research related to Industrlal economics and technologlcal development $1 \mathrm{~s}$ scarce. In the following 1 will focus on some contributions which elther go beyond Marx"s orlginal theory or which stress some neglected aspects of $1 \mathrm{t}$.

I w111 briefly discuss a controversy within neo-Marxist economics over the (non-)existence of monopoly capital and 1 ts far reaching consequences to the analysis of present capitalism. The debate is sometimes pursued at a level of high, mathematical, abstraction, 1ts consequences, however, are also relevant to emplrical research. If competition in modern capitalism would be (partially) surpassed by large monopoly capttals this could have far reaching effects on technological development as well. It would lead to situation In which a few companies would dominate Industries and all other companies would be doomed to stay in a longlasting. position of infertorlty. For the analysis of industry atructures this would lead to a differentiation of companies in atatic world in which there are but two categorles: monopoly capttal and non-monopoly capltal.

1) See R. Mishra, Technology and sactal structure in Marx": theory: an exploratory analysis, in: Sclence and Soclety, Vol. 43, no. 2, 1979, p. 154 and H. Braverman, Labor and monopoly cap1ta1, 1974, p. 9. 
In order to clarlfy some of the 1ssues related to monopoly cap1tallsm and technologlcal development from a neo-Marxist polnt of view I w11 discuss the contribution made to industrial economics by P.M. Sweezy at some length. His contribution is clearly representing the theory of monopoly capltalism His seminal contributons deserve special attention not only due to their large Influence on radical economics but in particular because of its schumpeterian flavour and the attention pald to technological development.

\section{Compet1tion and monopoly ox ol 1gopoly}

In radical but also in some other heterodox, Keyneslan insplred, contributions to economlc theory one can distingulsh two broad categorfes of theorfes on competition and oligopoly or monopoly. The debate between such theorles, in particular the one within Marxist polftical economics, is sometimes characterized as a true 'tribal war' where nuances are discussed as fundamental controversies ${ }^{1)}$. Nevertheless it is useful to see some differentiation between heterodox theories of competition and monopoly.

The first group of related theories stresses the development of capitalist economies with a (partial) disappearance of competition through the discretionary power of oligopolles over profits, prices and sometimes the introduction of new technologies. The dominance of oligopolles, or what is sometimes loosely defined as monopolies, 16 reflected in a herarchy of profit rates. Wellknown (politecal) economists within this tradtion such as Lange, Sweezy, Dobb, Kaleck1, Sylos-Labin1, Steind1 and representatives of the 'offlctal' theorles on state monopoly capttalism of commnist and some soclallst parties might be 'blen étonnés de se trouver ensemble'. Indeed, they differ with respect to many particular apects and theoretical roots of the 18 sue. However, the hlerarchy of proftcs and the asaumed discretionary power of oligopolles bulld a common element in these theorles. In many stralghtforward Marxist contributions the exiatence of monopoly

1) See e.g. H.J. Sherman, Monopoly capital vs the fundamentalists, 1n: $S$. Resnick and $R$. Wolff, 1985. 
proflts and monopoly capitallsm is frequently mentloned by referring to concentration within and centralization across industrles, coupled with constraints on the mobility of capltal due to high proportions of flxed capltal and the collustve behaviour of large corporations. In that particular context 'clasical' texts by Hilferding and Lenin bulld the foundation of many Marxist theorles of monopoly capitalism 1 .

In some of the more 'academic' contributions oligopoly and monopoly are treated in the context of theorles on industrial pricing and profits. In these theories, to which Semler refers as postKeynesian or post-Marxian, "... prices do not react in the short run to quantity disequilibria in the market. Prices are constituted by the cost of production (..) and a mark-up determined by the degree of monopoly" ${ }^{\prime 2)}$. Such mark-ups are in general determined by market structures, entry barriers and corporate power which leads to above average prices and consequently above average profit rates for oligopolies.

011gopolies, or monopolies as they are frequently referred to, and their price-setting pollcles have, according to such theorfes, changed capitalism into a new stage of monopoly capitalism. This stage of monopoly capttalism 18 not seen as "non-competitłue" but "... the nature of competition is radically transformed, with price competition, in particular playing a much smaller role" ${ }^{3)}$. oligopolistic rivalry, Industrial concentration and the growth of firms in absolute size are seen as Indicators of monopoly power in

1) See R. HIIferding, Das Finanzkapital, 1968 and V.I. Lenin, Het Imperialisme als hoogste stad1um van het kap1tallsme, 1973. Two qualifications are worth mentioning:

- H1lferding did not present a theory of monopoly or oligopoly stricto sensu but he referred to finance capltal resulting from mergers, cartels and trusts.

- Lenin wrote a 'popular' and political text in which he frequently referred to Hilferding and tressed the 1mportance of, what he somewhat confusingly labelled as, increased monopolistic competition.

2) W. Semler, Competition, monopoly and differential profit rates, 1984 , p. 59.

3) J.B. Foster, The theory of monopoly capttal1sm, 1986, p. 69. 
present capltallsm ${ }^{1}$. As a consequence of such theoretical elaborations 1t follows that there are two categorles of companies: price-setting monopolles and price-taking non-monopoly companies. Competition can take place efther between such 'monopolfes', or between monopolles and non-monopoly capltals in one industry or in case of absence of monopoly capital in a particular industry, between 'normal" companies'. I w111 return to some of the basfic assumptions and consequences of theorles of monopoly capitalism in a critlque of Sweezy as one of the most influentiel political economits and representative of this line of thought. Here it w111 suffice to note that such an approach leads to a simple dichotomy of compantes 1nto monopolies, or 0ligopolies, and nonmonopoly compantes.

In another attempt to theorize these 1 ssues from a radical perspective competition and rivalry are st111 seen as important aspects of capltal1st economic development. Consequently, the structural hierarchy of differential profit rates resulting from discretlonary power of some companles is denled. Such theories of competition, profit rates and industrial pricing elaborate upon classical polltical economists and Marx's theory of profits and prielng. As mentioned in the foregoing chapter, from this point of view, temporary and natural monopolles and many other 'accidental events" can effect Industrial prices and profits but, within the context of classical political economics such disturbances will not create structural hierarchy of profits for different unfts of capital. In classical and Marx's theories of production prices wark-ups are not determined by market structure related factors such as those mentloned above. Mark-ups in classical theorles of production prices "... are not arbltrary but determined by the structure of production and the cost of reproduction of labor powe $\mathrm{r}^{\mathrm{m}}{ }^{3}$ ). Semmler and C11fton representing thls second group of

1) See A.B. Idem, and H.J, Sherman, Monopoly power and prof1t rates, In Review of Radical Political Economics, Vol, 15, no. 2. Sumer 1983, and 1dem, 1985, and Sweezy's contribution.

2) See e.g. J. Wheelock, Competition in the Karxist tradition, in: Capita 1 Class, no. 21, 1983.

3) W. Semier, Marxian conception of competition, 1985, p. 64. 
theories, have shown that cost-plus or mark-up priclng in modern corporations is applied to control normal expansion of companles. As a rule it should not be seen as determined by market power but as consistent with a normal or average rate of return ${ }^{1}$. Such an approach is quite compatible with Morishima's theory of industrial pricing as the full cost principle for manufactured products ${ }^{2)}$. In an attempt to falsify the first group of theorles on ollgopoly and mark-up pricing Semiler is able to lllustrate that many studies show that mark-up pricing is found in both concentrated and nonconcentrated industries. Furthermore it is demonstrated in a valuable overvilew of many older and recent studies of market power and differential profit rates that there is no clear-cut evidence of a relation between concentration and persistent higher proft$a b 111 t y^{3)}$.

In this group of traditional Marxist and classical interpretations competition is seen as the movement of equalization of profit rates with disequilibrium in an unstable and uneven development both within and between industries. It leads to a, In my opinion, valuable criticlsm of the distinction between monopoly and competition or large and small firms in a static approach which is of 1ittle use since the growth factor is neglected. Monopoly, In the meaning of the appropriation of a rent e.g. for a new product, does not have to be excluded but then monopoly is not necessar1ly related to the size of companies. In this classical notion of monopoly it 1s, in principle, both short run and size independent even if transient monopoly can influence the growth potential of a company ${ }^{4}$.

1) See 1dem, p. 165, 1985, and J.A. Clifton, Competition and the evolution of the capitalist mode of production, 1n: Cambridge Journal of Economics, Vol, 1, no. 2, 1977 and 1dem, Administrered prices in the context of capttalist development, in: Contributions to Polftical Economy, Vo1. 2, 1983.

2) See M. Morlshima, The economfcs of industrial soclety, 1984, Pp. $27-31,68-98$

3) See W. Senmler, 1984, pp. 89-103 and pp. 111-128, see also M. Glick, Monopoly or competition in the U.S. economy, In: Review of Radical Political Economics, Vol. 17, no. 4, 1985, for a critical assessment of Semler's analysis.

4) See also R. Bryan, Competition and monopoly: a reply, in: Capital and Class, no. 30, 1986, p. 87 and J.A. Clifton, 1977, p. 150 . 
In order to clarify some of the 1 ssues mentioned above $1 t$ appears useful to pay some extrat atention to Sweezy"s theory of monopoly and related issues. In the past forty years P.M. Sweezy has become one of the most outstanding polltical economists and one who has pald extensive attention to ollgopoly (or monopoly), rates of proflt and, although to a lesser extent, to technologlcal development. Furthermore, Sweezy, who wa Schumpeter"s assistant at Harvard for some years, has to a large extent been influenced by both Marx and Schumpeter. Unfortunately, It was in particular Schumpeter's and Marx" emphasis on large corporations and not so much the dynamics in theit theorles that have been synthesized in sweezy' theory.

In the following. I w11 attempt to demonstrate, what I consider to be, some major shortcomings in Sweezy"s theory which can be seen as an example of some popular views in modern neo-Marxist polit1cal economics ${ }^{1}$.

1 will concentrate upon three issues in this theory:

- the monopolization and categorlzation of private capital;

- the structural differentlation of profit rates 1 into a hierarchy;

- the role of technology in the issues mentioned above.

Sweezy has frequently applied the analysis of monopoly and socalled monopoly capitalism to indicate, what is seen by him, as fundamental changes in the economy and the flrm. In this theory monopoly is presented as transformation of the firm as a result of both concentration and centralisation. If monopoly occurs there 1s, according to sweezy, no longer proflt maximization to the point where marginal costs equal marginal revenue or marginal rate

1) I am aware that Sweezy"s particular interpretation and modiflcation of the labour theory of value and the law of the tendency of the rate of profit to fall have been subject to a Ilvely debate in the past decades. These 1ssues, however, have but ittle to no effect on the spectfic subjects discussed here. See J.B. Foster, 1986, for a full coverage of (Baran's and) Sweezy's theory of monopoly capitallsm. 
of profit ${ }^{1)}$. Further expansion of this monopoly capital can only be found in new markets searching for new products, other companies (conglomeration) or new regions (multinationalization).

In an empirical analysis in his study on Monopoly Capital Sweezy has, together with Baran, made an attempt to operationalize this concept of monopoly cap1tal ${ }^{2}$. In this analysis private capital is divided Into two broad categorfes or sectors. One sector consists of small business, price takers, which is frequently coupled to calculations and strategles of 'B1g Buslness" 3 ). The other sector, monopoly capital, is qualified in terms of (quasi) synonyms such as glant corporatlons, large-scale enterprises, big buslness or oligopolies. This monopoly capital is seen as somewhat risk aversive in its strategles but well equiped for explolting the innovative activities of small business companles. Innovations are of ten "ploneered" by entrepreneurs and small business while "large companies" take over such activities once success has been proven ${ }^{4)}$. As demonstrated in some of the following sections these latter observations are not too far from what is accepted by many economists. However, the operationalization of monopoly capital and the categorization is too impressionistic, 'fuzzy' and 'popular' to enable the construction of a workable classification for empirical research. Whatever the usefulness of dichotomies for didactic reasons the complexity of economic structures can not be expected to fit into a simple division 1n two. As will be demonstrated in the empirical sections of this study and some theoretIcal elaborations in the following a further categorization of companies is more sulted for empirical research.

1) See P.M. Sweery the theory of capital1st development, 1968 (1942), pp. 275, 276 and 1dem, Modern capitalism and other essays, 1972 , p. 44 .

2) See P.A. Baran and P.M. Sweezy, Monopoly capital, 1966. The general afm of their study was to demonstrate that monopoly capitalism w111 lead to a tendency of the economic surplus to rise from which the refutation of Marx" law of the faling rate of profit follows.

3) See lidem, p. 62.

4) Idem, $P: 59$. 
In the above Sweezy was mentioned as one of the theorists of "a hiterarchy of differential rates of profit'. In his theory the establishment of a hlerarchy of proflt rates 1 s related to the transition from competitive cap1talism to monopoly capital1sm, as discussed by schumpeter, and changes in forms and methods of competition. Honopolization following from concentration and centrallation 18 add to lead to a rise in the rate of surplus value and a akewed distribution of profits in favour of larger compantes. There $1 \mathrm{~s}$ no tendency for profits to converge to an average rate of proftt, but Instead a hierarchy of prof 1 ts w11 emerge. Due to high bartlers for the mobllity of capltal in some sectors and low barrlers in others there will be a "... hierarchy of profit rates ranglng from highest in the industries of largescale production where close well-protected combinations are relatively easy to establish, to lowest in the industries of very sma.1-scale production where numerous firms co-extst and the case of entry precludes stable combinations" ${ }^{1)}$. So the hierarchy of profit rates is determined by the degree of monopoly or central1zation in industries. According to sweezy empirical evidence is found in the "... rough correlation between the height of the profte rate and number and size of firms in a given industry" ${ }^{2}$ ). A major problem wth 'rough' correlations, I find, is that these are often multi-interpretive and by definition not too strong. Furthermore, as already mentloned above, some recent surveys of a large number of studies on Industrial concentration, market shares and differential profit rates do not suggest an overwhelming evidence of the above mentioned correlation ${ }^{3)}$.

A complicating factor in Sweezy's theory of a 'structural differentiation' Into a herarchy of profit rates, 18 that it does not Imply that "... the Industries (or firms) at various levels of the

1) P.M. Sweezy, 1968, P* 274.

2) $1 \mathrm{dem}$, Four lectures on Marxism, 1981, p. 66.

3) See e.g. M.A. Utton, The political economy of big business, 1982. pp. 96, 97, and $W$. Semmler, 1984, pp. 111-128, and $N$. Rosenberg and L.E. Blrdsell Jr., How the West grew rich, 1986, pp. 289-295. 
hierarchy must always be the same. There is constant movement within the hierarchy in response to both Internal and external factors"1). Apparently the hierarchy is not too structural and one could even wonder why the notion of hierarchy has to be introduced In the case of constant movement. In fact a distribution of profits with changing positions over time comes very close to the classical concept of 'center of gravity' for profit rates.

The final subject of this critlque of sweezy's work relates to his perception of the role of technology in capitalist development. As with so many other neo-Marxists technology itself is not at the core of Sweezy's work but is scattered troughout his contributlons. Sweezy, and also Baran, claim that under present monopoly capitalism there will be a slower rate of tatroduction of innovations than under competitive capltalism. In competitive cap1talist circumstances innovation brings extra profit for the first Innovative compantes as others lose their share of the market. Under monopoly capltalism, according to Baran and Sweezy, labour saving process Innovations but also product Innovations are introduced or regulated at a pace which does not disturb the existing capttal values. Price cutting policies in order to 'smoothen" the absorption of the output of both old and new methods of production is ruled out as unrealistic "... given monopoly capitalism's strong bias against price cutting ..."2). Following Joan Robinson It is assumed that a monopolist w11 not introduce new captital equipment and scrap existing equipment unless cost savings on new equipment plus interest is less than the costs of maintaining the existing equipment ${ }^{3)}$. This does not necessarily loply that there w11 be a dramatic decline in the rate of invention itself under monopoly capitalism. The intensive use of science and technollogy by large corporations can even speed up the rate of discovery and

1) P.M. Sweezy, 1981, p. 66.

2) P.A. Baran and P.M. Sweezy, 1966, p. 100, this, In my oplnion, mistaken conception of compet1tive strategies is supported by many radical economists, see e.g. M. Aglietta, A theory of capitalist regulation, 1982, pp. 304-313.

3) See P.A. Baran and P.M. Sweezy, 1966, p. 101, see also P.M. Sweezy, 1968, p. 276. 
potentlal Innovations. However, as Baran and Sweezy claim "... under monopoly capttallsm there $1 \mathrm{~s}$ no necessary correlation (...) between the rate of technological progress and the volume of investment outletsil). In general the fntroduction of inmovations Is planned by monopoly captral itaelf and Schumpeter's creative destruction w111 not occur under these ctrcumstances.

The main shortcoming of Sweezy' treatlse on monopoly and technologtcal development $1 \mathrm{~s}$ the jumplng to conclusions from a highly abstract and theoretical discourse to a concrete analysis without taklng the intermediate steps. The result is a typical case of "economics with blinded windows". In abstract theory sweezy"s statements and derlvations could hold In case of pure monopoly, the absence of creative destruction, and unchanged demand cond1tlong. However, this does not permit conclusions for empirical situations, unless concrete monopolization in strict terms has been adequately demonstrated. As mentioned before, sweezy switches from a "tlght" definition of monopoly in abstract theory to a very 'loose' description of monopoly when analyzing current capitalism where large corporations, oligopolistic market structures, etc. are defined as monopoly capltal. All this leads to conclusions e. $g$. for the relation between monopoly capttal, large compantes, and the rate of the Introduction of Innovations whlch are not supported by any evidence from empirical research. Furthermore, at the present stage of capitalist and technological development both flerce competition with price-wars, shortened product-life cycles, changing market structures and technological change induced by many companies provide clear obfections to this element of Swerezy" theory.

The world of technology and capltalist development shows a differentlated picture with many categorles of Innovative compantes and change in technological progress, as such it appears to be a far cry from the world pictured in Sweezy's system of monopoly capitallam.

1) P.A. Baran and P.M. Sweezy, 1966, P. 103. 
Marxist and neo-Marxist political economics has pald little attention to technological development in present-day capitalism as we search for new Ideas and new analyses. But few have made an attempt to go beyond or even expand the fleld of research la1d out by Marx himself. This does not mean that there has been no theoretical development in radical economics itself but most attention has been pald to other developments than those related to industry and technology. In some Marxist and other heterodox theorles attention was pald to rather abstract elaborations upon monopolization. Theorles on oligopolization or monopolization, although sympathetic at first sight, have not been too persuasive in presenting an unambiguous support for the thesls of a structural differentiation of companies into persistent different levels of profit. So far, no evidence of high correlations of industrial concentration and persistent difference in profitability have been found unanimously. In other words, there 1s little evidence of the existence of a monopoly capital leading to structural monopoly proftts other than in exceptional cases.

Sweezy's work can be seen as an example of a popular misunderstanding of present-day capitalism amongst neo-Marxists. Abstract theorizing of monopoly, technological development and strategy is 'translated' into an emplrical analysis assuming the correspondence of 'monopoly" and large compantes. In abstracting from competition, technological development and diffusion capitalism is misunderstood as a non-dynamic economlc system.

Such critle1sm of neo-Marxist theory is in my opinton, more fruitful than the approach chosen by some orthodox Marxists who have criticized the theory of monopoly capitallsm as a deviation from Marxist political economics. In that context Foster has correctly stated that for the $\log i c$ of the argument it 1 s completely irre1evant whether Marx had a theory of monopoly capitallsm or not ${ }^{1)}$.

1) See J.B. Foster, Is monopoly capitalism an 111 ision?, in: Monthly Review, Vol. 33, no. 4, 1981, p. 37. 
Criticlsw cannot be based upon any reference to the absence of such a theorem in Marx"s theory. Orthodox criticism based upon 'purtsm" is fallaclous Indeed, as too many elements in Marx's general theory are outdated and inconslistent. It is much more fruitful to discuss neo-Marxist contributions with respect to their applicablity and empirical relevance. Then, contrary to e.g. Foster, I think neo-Marxist theorles of structural monopoly are of 11 tele relevance. This does not mean that concepts such as monopoly and ollgopoly have no purpose in economic analysis. In concrete analysis monopoly and ollgopoly, lf properly defined and understaod, could be applied to describe and analyze production and market structures. Applied as a base for classiflcations of companies or theory of technological development under a cap1tallet mode of production they are of little use.

3.3 THE SCHUMPETER CONTROVERSY

Within the more traditional, academic, school of modern Industrial economics and Innovation theory one Important issue has attracted much attention during the past decades. It has become well-known as the on-golng debate on the so-called schumpeter controversy on market structure, firm size and innovation ${ }^{1)}$. The issue is related to two question:

- which level of Indugtrial concentration is most conducive to Innovation; and

- what size of firm ls most appropriate to stimulate Innovation? It 1 s clear that these questions are not only of a theoretical relevance but they are 1 so very 1 mportant w11 respect to the Implementation of (atate) pollcles. In the public debate on Innovation pollctes in the past decades one observes a somewhat cyclical movement in the argument. In the fiftles and sixties Industrial concentration and the supremacy of large companles were accepted by many as most sultable for generating new products and industrial processes. In the seventies and early eighties a change in

1) In the following I will refer to Industry and market structures as synonyms, although strictly taken the latter concept is broader and encompasses the flrst. 
the debate can be observed in the sense that small, and of ten new, firms are seen by many as the true Innovative change agents of industry. The public debate so far has, in wy opinion, largely been Influenced by popullst and ideologlcal bellefs about what Innovation policy should be pursued. However, this does not wean that economic research and theory has not been medlated to a certain extent within the public debate. So far, any point of vilew on this matter can be backed by bits and pleces of research and theory. In academic economic theory the debate can be traced back to a long-standing controversy over the effliclency of large (or smal1) compantes ${ }^{1)}$. It goes back to Marshall's theory of decreasing returns to scale expressed in the rising portion of the long-run average cost curve. This theorem has been countered in later years by those who point at improved Information control and co-operation within the so-called M-divisional structure of large companies. The proclaimed Inefficlency of large companles has also been discussed in the debate on their lack of control over cost levels (X-efficiency), which others clalmed were countered by competition and improved organization. As far as the (in-) efficiency of large companies in thelr innovative performance 1 s concerned both sides have generated evidence supporting thefr point of view.

If reduced to stralghtforward dichotomles the complexity of economic performance, of which Innovative capablitty is an important aspect, is frequently simplifled to statements such as: large companies/sma11 companies or concentrated Industries/atomistic industrial structures are most efficient and stimulating for innovation.

Many wlll agree that such plain dichotomies are even at first sight probably too simple for understanding what everyone can expect to be a very complex aspect of economic reallty. Economic theory so far has advanced in the past decades in the sense that the complexity of the issue is recognized in more subtle explanations. That 1a not to say that the "truth" lies in the middle but in many contributions one part of the coln 1 s represented with at least some reference being made to certain features and relevance of the other part.

1) See e.g. M.A. Utton, 1982, pp. 5-15. 


\section{tration}

In their outstanding review of studles on market structure and innowation kamien and Schwartz have sumbrized the set of Schumpeter, or probably more conventent schumpeter 1msplred, hypotheses as follow: :

"1. Innovation 18 greater in monopolistic industries than in competitive ones because

(a) A firm with monopoly power can prevent imitation and thereby can capture more profit from an innovation.

(b) A firm with monopoly profits is better able to finance research and development.

2. Large firms are more Innovative than small firms because

(a) A large firm can finance a larger research and development staff. There are ather economies of scale in this activity also.

(b) A large diversifted firm is better able to explott unforseen Innovations.

(c) Indivisibility in cost-reducing Innovations makes them more proftiable for large firms.

3. Innowation is spurred by technological opportunity.

4. Innovation 1s spurred by market opportunlty (demandpu.11) ${ }^{n 1)}$

The third and fourth hypotheses are not necessarily schumeterInspired but they are relevant for adjusting studles on Innovation for differences in technologtcal and market opportunity. The first two sets of hypotheses can be accepted as what 1 senerally seen as the core of a Schumpeter-Inspired theory of Innovation.

Whether these hypotheses can also be attributed to Schumpeter is of course matter of debate. From my perception of schumpeter"s theory there are at least some modiflcations for this set of hypotheses to be made. These reservations w11 becone clear when I briefly recall some of the Important aubjects in wy view of Schumpeter's theory of Innovation.

1) M.I. Kamien and N.L. Schwartz, Market structure and Innovation, 1982 , p. 47. 
For Schumpeter Innovation, the creation of new comblnations, is the notor of economic development creating disequilibrium and Imperfect competition in the economy. Schumpeter's own perception of disequilibrium and Imperfect competition might have changed slightly in the course of his theoretical development, but at all stages their relevance for understanding the dynamics of economic change was stressed.

In Schumpeter's earlier works innovation is understood within the world of entrepreneurial capitalism in which "herolc" entrepreneurs, and not capitalists as such, Introduce fnnovations to gain profits or extra-profits. Transient, short-run, monopaly on new products or processes triggers imitative reactions in other compantes and through this imitation and diffusion the monopoly position of early introducers wears-off. In this picture of classical 19 th century capltalism entrepreneurs in extsting but also in new companfes set the scene for Innovation.

In his later works Schumpeter referred to modern, trustifled capitalism as 20 th century capitalism. Here, large companies, which are frequently also sclence-based with formalized R\&D departments, dominate the process of Innovation. In these large companies Innovation has become routinized. Small companies do not play a very distinct role in generating innovations, their economic role is "restricted" to market-niches and the provision of services to large companies.

Schumpeter discussed monopoly in particular in terms of short-run, transient monopoly which disappeared through the diffuston of an innovation. Long-run monopoly was geen as an exceptional case. The actual $11 \mathrm{mits}$ to both forms of monopoly was set by the effects of creative destruction. In short, this notion of creative destruction was Introduced by Schumpeter to stress the Importance of the creation of new and the destruction of older Industrial atructures. In other words industrlal development 18 marked by the growth of new sectors and other companies than the existing. dominant companies.

Returning to the set of Schumpeter inspired hypotheses mentioned by Kamien and Schwartz the following qualifications, In particular wth reference to the first two sets of hypotheses, are to be made : 
It w11 be clear that hypotheses regarding the greater innovative potential of large companies can be seen as schumpeter-11ke hypotheses. (But then one refers in partlcular to his later works).

The first set of hypotheses about monopolistic warket structures 16, so to speak, more "Inspired" than related to schumpeter"s theory. Schumpeter referred much more to large firms and market power than to lasting monopoly as a structural phenomenon of Industrial development. A concentrated market structure is not necessarlly conduclve to Innovation according. to Schumpeter"s theory ${ }^{1)}$.

One of the most popular advocates of the supremacy of large firms 1s the American economist Galbralth. In two of his famous texts this supremacy of large companies in many aspects of their business operations 18 frequently mentioned ${ }^{2)}$. In his work the whole set of arguments in favour of large flrms and concentrated markets, flrm size and market structure, are usually intertwined. Although he clearly states that he comes from a different trad1tion in economic theory Schumpeter 1 mentioned by Galbraith as the main inspiration of his thoughts on firm size, industry structure and innovation. In the broader context of his general theory Galbralth plctures a world of modern capltalism in which large companies act no longer as price-takers. These large compantes with ollgopolistic features pre-empt the market before maximum output equals lowest prices. This form of inefficlency is offset by the benefits of technical change leading to a host of new producte frot these large companies. Competition is no longer

1) See e.g. Aso R.R. Nelson and S.G. WInter, An evolutionary theory of economic change, 1982, p. 279, and $F$. Chesnais, Schumpetertan recovery and the Schumpeterlan perspective - Some unsettled lseses and alternative interpretations, in: $H$. Giersch (ed.), EmergIng technologies: Consequencles for economle growth, atructural change, and employment, 1982, p. 61.

2) See J.K. Galbrath, American captcal1om, $1970(1952)$ and 1dem, The new Industrial state 1985 (1967). Although Galbraith changed his views on some subjects discussed in these publications, his thoughts on the role of large compantes in technological change apparently has not changed over the past thirty years. 
determined by prices but olfgopolistic rivalry 18 determined by advertising, sales efforts and innovation strategles of these companies. According to Galbralth "... modern industry of a few large companies (is) an excellent instrument for Inducing technical change. It is admirably equipped for financing technical development. Its organization provides strong incentives for undertaking development and for putting it into use"1). Like Schumpeter he admits that small companies and entrepreneurs have played an important role in "competitive capitalism'. However in modern capttalism and "... with the rise of the modern corporation, the emergence of the organization required by modern technology and planning and the divorce of the owner of capltal from the control of the enterprise, the entrepreneur no longer exists as an individual person in the mature industrial enterprise" 2 ). In that context Galbraith asserts that competition and competitive markets are not very well sulted for innovation as diffusion and imitation destroys the profit of innovation because imitators are quickly to take advantage of the inventive activities of the orIginal Innovators. Furthermore, wost cheap inventions have already been made and modern technology has become very expensive, which diminlshes the likelthood of recovery of those costs in a truly competitive market. According to Galbraith, larger firms, with substantial market power, can control the length of time of the benefits of their innovations. "Thus, in the modern industry shared by a few large firms, size and the rewards accruing to market power combine to insure that resources for research and technical development will be avallable. The power that enables the flrm to have some influence on prices insures that the result1ng galns will not be passed on to the public Imitators (who hove staod nome of the costs of development) before the outlay for development can be recouped. In this way market power protects the incentive to technical development" 3 ).

1) J.K. Galbralth, 1970 (1952), p. 100 .

2) idem, $1985(1967)$, p. 64 .

3) Iden, $1970(1952)$, p. 102. 
In other words: large firms and concentrated market structures are fawourable to technical change. The relation between these goes efther way as the expensive character of sclence based technical change also influences the existence of concentrated markets and large flrms.

In that context Galbratth mentlons $\$ 1 x$ consequences of modern technology for Individual compandes ${ }^{1)}$ :

- wh the sophistlcation of technology there is an increasing span of time from beginning to completion of an innovation;

- capital Invertments Increase;

- there 1s a larger division of tasks and weans of production;

- more speclalized manpower 18 needed;

- more organtzational forto have to be made;

- and by consequence more planning 1 s compulsory.

It 18 clear that in Galbralth"s view of the consequences of technological development there is little left for small companies. His theory is doubtlessly one sided in the sense that he plctures a world dominated by ollgopolistic compantes. Apart from the fact that I disagree with Galbratth's theory on Industrial pricing and ollgopolistic rivalry, because full cost theorles are more plaus1ble, the Schumpeterian aspects in his theory still have to be qualified.'Galbraith discusses concentrated market structures and large companies almost as synonyms, which 18 , I think, not allowed without explalning particular conditions under which the two are closely related. In general, Galbratth's theory on the dominance of large glant companies, the 2000 leading companies in the USA, 18, if restricted to technologtcal development, of a clear Schumpeterian character. Other aspects of Schumpeter such as 'creative destruction' and the growth of companles which are relevant In understanding the dynamics of market structure and innovation are not discussed in Galbraith's theory. In particular the absence of some understanding of changes In Industry structures, the growth and decline of Industrles and the changes whin Industries, makes Galbralth" theory to a otatic varlant of schumpeterian theory. In that sense 1 t has a close resemblance to some neo-Marxist theorles of monopoly capital1sm, such as Baran and Sweezy's.

1) Iden, 1985 (1967), pp. 12-16. 
The supremacy of large companles, as theorlzed in the Schumpeterinspired theory of Innovation has been questloned by many. In response to e.g. Galbralth's theory a debate on the proclaimed efficlency of large companies and the role of glant corporations as great Innovators started in the early fiftles and the debate has lasted ever since ${ }^{1)}$. A well-known adversary of the schumpeterGalbraith theory is Blatr. In his contribution Blalr put forward exactly the opposite of what has been discussed above: In his theory of the so-called "creative backwardness of bigness" Blatr attributes this backwardness amongst other things to:

- the desire to protect the Investment in an older technology:

- Indifference to technological advance;

- underestimation of the demand for new products;

- neglect of the inventor;

- misdirection of research and incompatibility between organization and creativity ${ }^{2}$.

Although definitely not tientical, many aspects of this proclatmed backwardness are related to what is also known as dynamic $X-1 n-$ effictency ${ }^{3}$.

others have paid more attention to industry specific conditions which influence the posttion of large or smal1 companies. E.g. Freeman states that both Galbraithlan and opposite theorles represent only a part of the picture. There are some industries like aerospace, vehicles and pharmaceuticals where small firms make no or almost no contribution to innovation. In other sectors such a sclentific instruments, textlle and construction small firms do make an important contribution to techn1cal change ${ }^{4)}$.

1) See e.g. W. Adams, Competition, monopoly and countervalling power, in Quarterly Journal of Economics, Vol. 67, no. 4, 1953 as an 'early' contribution and e.g. M.I. Kamilen and N.L. Schwartz, Market structure and Innovation: a survey, in: Journal of Economic L1terature, Vol. 13, 1975, and idem, 1982, and $C$. Freenen. The conomics of industrial innovation. 1982 for an overview of many contributions.

2) See J.M. Blair, Economic concentration, 1972, pp. 228-257.

3) See e.g. A. Heertje, Economics and technical change, 1977 , pp. $215-219$.

4) See C, Freeman, 1982, p. 141. 
Some authors gtress the Importance of a balance between large and small firms, or a mix of both companies in the economy 1 ). In that context Rothwe11 and Zegveld mention the advantages and disadvantages of small and medium sized flrms, which can also be seen as the mirror lmage of large companies. Advantages for smaller companieg are, according to Rothwell and Zegveld, in particular found $1 \mathrm{n}^{2)}$

- their able marketing for particular niches;

- dynamic, entrepreneurial management;

- Internal communication. (Their argument supporting the 1dea of resulting excellence of labour relations in small companies is probably too optimitic.);

They also mention considerable number of disadvantages for gmal1 companies auch as:

- their lack of qualified RSD personnel;

- shortcomings in external communication, In particular a lack of information on technology and markets;

- lack of management skills;

- constrained financial resources;

- problem related to economies of scale and selling of turnkey projects and complete systems;

- disab1lity to take advantage of government measures;

- problems related growth of the firm.

Many of these (d1s)advantages can also apply to new companies. In particular in some of the earlier works of Schumpeter new companles were seen as innovative. From the literature one learns indeed that new firms share many of the advantages of small companies. Whether new companies also play an Important role in generating Innovations stil has to be seen. E.B. Johnson concludes, after having reviewed the 11terature, that "... 1t seems that most

1) See D. Sahal, Technology, productivity, and Industry structure, 1n: Technologtcal Forecasting and Soc1al Change, Vo1. 24, 1983, PP. 11, 12 and $\mathbb{R}$. Rothwe11 and W. Zegveld, Innovation and the sma11 and medium sized firms, $1982, P .75$, and $R$. Rothwel1, The rolle of smali f1rms in technological innovation, in: J. Curran
et a., 1986 .

2) See R. Rothwel1 and W. Zegveld, 1982, pp. 45-54, see also R. Rothwe11, 1986, pp. 116, 117 . 
of new firms are not Innovative In the Schumpeterian sense (1.e: 'early' Schumpeter, J.H,), although many of then may have some marginal advantage over competitors"1). However, a study by Dorfman to be discussed in the next section suggests the opposite for some 'h1gh-tech" sectors" ${ }^{2}$.

So far, the literature on market structure, size of f1rm and 1 nnovation demonstrates that in between the 'extremes' there is a fleld of nuances and second thoughts. Arguments in favour of elther side of the Schumpeter controversy can be countered with some reservations ${ }^{3)}$.

Some attempts have been made to develop a theory in whlch the different roles of small and large companies are emphasized. E. g* Scherer has made an interesting attempt to generalize research on the relation between both market structure, firm size and innovation. Scherer's theory can be summarized as follows ${ }^{4)}$ :

Small and medium sized firms contribute significantly to the inttial stages of Innovations, but large corporations appear to have a particular task of developing Inventions into the stage of commercial success. In that context three generalizations are made:

- small firms play a 'disproportionate' role In developing new Ideas;

- the further development usually requires investments which cannot be met by sma11 and medium sized firms;

- these private Investments can be undertaken by (very) large corporations or by medium sized firms with a "high tolerance for risk".

Furthermore, for both RAD Input and output 1 t 18 sald that these tend to rlse less than proportionally to size once a threshold has

1) P. Johnson, New flrms, an economic perspect1ve, 1986, pp. 36, 37.

2) See N.S. Dorfman, Innovation and market structure, lessons from the computer and semiconductor industries, 1987.

3) See R.W. Shaw and C.J. Sutton, Industry and competition, 1976, p. 203 for an averview of arguments in favour of high concentration and large firms and mafor reservationis.

4) See F.M. Scherer, Firm size, market structure, opportunity, and the output of patented Inventions, In: American Econotalc Review, Vol. 15, no. 5, 1965 and 1 dem, Industrlal marketstructure and economic performance, 1980. 
been passed. Th1 leads towards the so-called 'humpack' or "inverted U-shape' distribution. Th1s 'inverted U-shape" distribution 1s algo mentioned for the relation between market structure and innovation.

Wiliamson arrives at somewhat simllar conclusions for size of firma and innovation stating that "... R\&D expenditures (expressed In relation to flrms stze) are not usually greater and are of ten lower for the very largest firms in an industry by comparison with 1ts large but somewhat smaller rivals; the productivity of research expenditures follows roughly the same pattern; (...); research conducted in most large industrial laboratories favors minor improvement inventions rather than new inventions ....1).

These complementary roles of small and large firms in a stuation. In which small firms invent new products and processes and larger companles take care of the further development and subsequent stages such as market1ng is accepted and stressed by many authors $^{2)}$. Theorles of W111lamson, Mueller and in particular scherer can be seen as examples of neo-Schumpeterian inspired theories of 1unovation. The Importance of small companies to the process of Invention and Innovation, as partly featured in Schumpeter's early theory, is stressed. The growth of research intensity of larger companies and concentrated markets as mentioned in the Schumpeter insplred hypotheses mentioned before 1 emphasized, as well. However, such neo-Schumpeterian theorles also mark the less than proportional to size contribution of the largest companies once a threshold has been passed.

Two other relevant contributions from a neo-Schumpterian perspective to this fleld of economic theory are worth mentioning. The first contribution to be discussed is the attempt made by Nelson and Winter to theorize and model Schumpeterian aspects of compet1tion and Innovation ${ }^{3)}$. The theory of Nelson and Winter and their

1) 0.E. W1111amson, Markets and hierarchles: Analysis and ant1trust Implications, 1975, p. 196.

2) See also C. Freeman, 1982, p. 137 and D.C. Mueller, The modern corporation, 1986, pp. 108-118.

3) See e.g. R.R. Nelison and S.G. Winter, 1982, and R.R. Nelson, Understanding technical change a an evolutionary process, 1987, pp, $37-43$. 
simulation models touch upon many subjects ranging from macroeconomics to the theory of the firm and the dynamics of technological development. The richness of thelr contribution enables me to come back to their contribution in another chapter, In particular with respect to the dynamics of technological development. Here, I w11 restrict myself to a brief dlscussion of some theoretical conclustons from their modelling of Schumpeterian competition. Central to Nelson and Winter's models is disequilibrium which is featured as an Important characteristic of economic development. Furthermore market structure and innovation are seen as Interdependent, hence market structure is endogenous. Compet1tion is not a static phenomenon but a process in which winners and losers are generated. Winners are those companies which make better use of technologlcal opportunities which enables them to grow. Losers are those compantes which take less advantage of technolog1cal opportunities after which they gradually decline into a stage of technological obsolence. Losers do not necessarily disappear from the market, some of them can languish for extended periods of time. The simulations wth Nelson and Winter's models generate some interesting results for the study and theory of market structure, slze of firms and innovation. First of all their findings suggest that already concentrated industrles remaln concentrated, although "... the actual exercise of market power by the larger firms (...) may be an important factor in tending to limit the growth of concentration in the Industry"1). Initially unconcentrated Industries gradually become more concentrated as winners grow and losers decline.

other conclusions from Nelson and Winter"s models are:

- relatively concentrated Industries provide a "better ihelter" for R\&D than atomized Industrles;

- "... Industries with rapid technical progress ought to be marked by high average R\&D Intenstty and, as the industry matures, by a more concentrated industry structure than Industries in which technical progress 1 s slower ..." ${ }^{2)}$

- skillful and agressive imitators can compete successfully with innovat Ive RSD performers.

1) R.R. Nelson and S.G. Winter, 1982, p. 326 .

2) idem, Pp. 350, 351 . 
A shortcoming in Nelaon and Winter's theory is that the long term effect of entry and creatlve destruction is somewhat neglected. In modelling Schumpeterian competition the role of entry is restricted to a situation comparable to an existing small company". From perception of schumpeterian competition entry, cross-entry and diversification can have a further reaching effect on changes in existing indugerlal structures.

A related approach to the dynamics of market structure, size of firms and Innovation has been introduced by Dosi. His theory has certain Schumpeterian features in common with Nelson and Winter in the attention pald to the asymetry of firms in relation to technlcal change. It also has some features from classical economics In the treatment of campetition and proftt rates in a "centre of gravity' approach, which is quite distinct from e.g. Nelson and Winter. Dosi is rather sceptical about theory and research on market structure, firm size and innavation so far. In his critique of the state-of-the-art an alternative explanation for the socalled Inverted U-shaped relation between 'innovativeness' and firm size and concentration is suggested. This hypothetical explanation supposes that:

- the degree of Innovativeness is a negative function of the technological age or maturity of an industry, technological maturity being the inverse measure of technological opportunity;

- concentration is a positive function of past innovativeness and technological maturity, making market structure endogenous;

- for any given technological maturity, Innovativeness is a positive function of firm size.

Then, according to Dosi, there could be an inverted U-shaped relation in the economy as whole even if Innovativeness grows proportional to size ${ }^{2}$. From whlch one $1 \mathrm{~s}$ to conclude that the actual shape of the relation between Innovation, firm size and market structure for a particular economic system depends upon the

1) 1dem, p. 328 . 2) See G. Dosi, Technical change and industrial transformation,
1984, Pp. 92,93 . 
Intersectoral pattern and the "state" of technology applied in each sector. Although Dost himself does not mention it, such a dynamic analysis of firm size, market structure and Innovation can be viewed in the light of Schumpeter's emphasis on creative destruction.

A full treatment of Dosi"s theory of ollgopoly would take too far, but one issue should be mentioned here. In Dosl's theory a distinction 1s made between two different phases of technological development and oligopolistic structures ${ }^{1)}$. In case of the emergence of a new fleld of technology it is stated that there will be a high rate of birth and mortallty of new companies with temporary oligopolies which can pre-empt new markets.

In case of an already established fleld of technology there wiJl be a more stable oligopolistic structure and entry barriers, then technical change becomes part of oligopolistic competition as e.g. also Galbraith has argued. This differentiation $1 \mathrm{~s}$ to be seen as an attempt to integrate two distinct approaches in e.g. schumpeter"s theory. The first situation is quite similar to Schumpeter"s early theory of competitive capitalism, the second is more related to his theory of advanced capitalism. I think it is useful to stress that even in the latter case existing ol1gopolistic structures, and entry barriers will have to be seen as temporary. From a Schumpeterian perspective existing oligopolistic structures are not excluded from cross-entry, in particular not if the industry is st11l characterized by an above average level of growth. In case of a mature sector of industry characterized by stagnation or decline it is not so much entry barrlers as exit barriers for non-diversifled or specialized, compantes which cause stable oligopollstic structures ${ }^{2}$. Such conslderations lead to an approach in which the reciprocal effects of exlsting ollgopolistic structures, mobility barriers, Intersectoral competition and the "maturity" of a fleld of technology have to be taken Into consideration.

1) 1 dem, Pp. $93,94$.

2) See also W. Semmler, 1984, p. $111 \mathrm{ff}$. 
A major problem for applied economic research in this field is that the dynamites of (Inter-) gectoral change and technological development can lead towards an 1rregular process of changes wthin an exlating industry. E.B. In the case of the sector of proces control equipment it can be demonstrated that mature 1ndustry. has evolved towards a new phese of its development. Process control based upon preumatic princlples was not only a mature technology, 1 t was also produced by a 'stable' group of manufacturers. The intraduction of electronles, computer technology and at later stage the further application of the complete range of information technology changed the industry structure. The technology applied became more sophisticated, existing companies merged or were taken over, electronics manufacturers entered the market et cetera.

In other words, a mature Industry developed towards a stage where new technologles are introduced and incorporated. Side entries, take-overs of companies with experfence in relevant technologies and concentration have led to a sltuation in which ollgopolistic rivalry in that particular sector has become but a momentum within a larger 'game' of competition.

The theoretical contributions discussed above suggest that the complexity of the relation between firm size, Industry structure and innovation has been recognized by many. Generallzations are hard to make. Arguments in favour of large compantes such as provided by e.g. Galbratth are not completely beside reality eventhough only certaln features of modern capltalist society and the rolle of large compantes are stressed. The same could be stated for those who stregs the opposite pleture in which the role of the small company as the Innovator is stressed. Some authors apparent$1 y$ choose to be on the safe s1de and stress that both large and mall companies have certain, albelt opposite, characteristics which, If balanced, generate a successful innovative climate. Others stress the importance of intersectoral and dynamic changes in order to understand the 1ssue. In that context 1t has been argued that: 
- Small companies play an important role at the lnitlal stage of innovation, this role is taken over by their large competitors at the stage of further development and commerclallization.

- The contribution to Innovation of very large compantes is less than proportional to their size.

- Industrial concentration has a positive effect on innovation, but the effect is less than proportional once a threshold of concentration has been passed.

- Sectors with rapld technological progress become more concentrated than sectors with slow progress.

- Different forms of oligopoly, barriers to moblilty , and varying Industry structures and dissimilar levels of technological maturity are decisive in explaining differences in innovative performance.

3.4 EMPIRICAL STUDIES ON THE SCHUMPETER CONTROVERSY

Theoretical contributions to the Schumpeter-debate so far suggest that one can choose not only between extremes such as: high (low) industrial concentration is most advantageous to innovation or large (smal1) compantes generate more innovations. A substantial part of the theory provides more intermedlate, subtle or indistinct elaborations upon probably too crude dichotomies in the theory on the subject. Most theories mentioned previously are based upon empirical observations but it ls falr to state that these observations range from circumstantial evidence to econometric research. Having stated some of the 1 ssues in economic theory it appears useful to glance some of the more empirical studies. Fortunately several well-known surveys of empirical. studies have been published which enable me to present the stateof-the-art without "carrying too much coal to Newcastle'. This overvlew of these findings and the review of some recent studies explicitly does not attempt to replace these outstanding and thorough surveys. The aim of this section 1 s much more to concentrate on what can be learned from the vast body of empirical studies in terms of generalizations or dead-ends. If the state-ofthe-art would lead to dead-ends or superficlai generalizations it is worth looking for new departures. 
Before I turn to these studies I w11 first make some brief remarke about the measurement of technology, innovation and RSD. A majot problem in assessing the large body of emplitical research in this and related issues is that one can cast some serlous doubts about the compatiblitty of different indicators applied in empirtcal research such as patents, R\&D-employment or expenditures, etc. Every Indicator has its speclfic shorticomings. E.g. R\&D flgures, whether measured in value or in employment, tell ws only gomething about one aspect of the technological development, the research input. Patents as such measure only inventive output in terms of how many Inventions are administred but little about their importance and thelr effective application. Also, differences in propensity to patent between sectors of Industry and countries can be expected. The different attitudes towards formal R\&D and patenting amongst categories of firms related to size can influence the "neutrallty' of varlables to be measured. Research by Schmookler, Pavitt, Soete and others suggest a lower propensity to patent by large compared to small firms ${ }^{1}$. Furthermore, many studies apply different indicators for innovation such as R\&D, patents or innovations mentioned by experts which causes some ahortcomings in comparability. Al1 of which suggests that even if some generallzations about firm slze, or market tructure, and Innovation were to be made these will have to be interpreted with utmost care.

\section{Market_structure_and Innovat1on}

Market atructure and Innovation, and size of firms and Innovation are sometimes discussed as if these are Identlcal or almost Identeal toplesi strictly taken these relations are of a different character. E. B. J.B. Rosenberg found that market share and Industrlal concentration, two operational definttions of market structure, had greater impact on innovation than absolute size of compantes $^{2)}$. In my atudies on the relation between market structure

1) See C. Freeman, 1982, p. 136 and L. Soete, Inventive activ1ty, Industrial organtzation and international trade, 1978, p. 187.

2) See J,B. Rosenberg, Research and market share: A reappraisal of the Schumpeter hypothesis, In: Journal of Induatrial Economics, Vol. 25 , no. 2, 1976, p. 107. 
and Innovation the optimal configuration of companies to stimulate technological development is a central theme. Questions on the optimal size of firms with respect to innovation or the actual distribution of innovations over categorles of firms" size are not necessar1ly related to market structure. However as soon as oligopoly is introduced and when more industry specifite circumstances: are considered market structure and size of firm are easily connected. Quite simply because large firms frequently play a dominant role in concentrated markets and/or oligopolistic rivalry. But even there the relationship between firm size, market power in case of oligopoly, market structure and indicators of innovation is complicated. As e.g. Culbertson has demonstrated the effect of absolute and relative firm size and market power on industry RoD expenditures is mediated by technological opportunities and individual firms' RSD $^{1}$. For the sake of clarlty and acknowledging such objections against a simpliflcation of the matter I will discuss the relation between innovation and market structure and firm size separately.

If one looks at the state-of-the-art in empirical research on market structure and innovation one can find some consensus, but only at a level of extreme generality. In most studies market structure is operationalized in terms of concentration ratio's. Innovation is in most cases defined in terms of either research Input, $\mathbb{R} \& D$ expenditures or numbers of $R \& D$ employees, or research output for which numbers of patents are taken. Kamien and Schwartz found little consensus in reviewing well-known research on the relation between concentration and research input in studies by Scherer, Comanor, Hamberg and others. Research on the relation between concentration and Innovative output apparently led to a simflar conclusion ${ }^{2}$. If anything follows from these studies it is the suggestion that there might extst the previously mentioned

1) J.D. Culbertson, Econometric tests of the market structural determinants of R\&D investment: Consistency of absolute and relative $11 \mathrm{rm}$ size models, In: Journal of Industrial Economics, Vol. 34 , no. $1,1985$.

2) See M.I. Kamien and $N_{*}$ L. Schwartz, 1982, p. 86 ff. 
humpack or Inverted-U relationship between industrial concentratIon and RAD imtensity. In other words, lf concentration develops towards 1ts theoretical waximum this will lead to a gradual decline of the RAD intensity again.

Having reviewed the vast body of studies on this and related issues performed In the sixties and seventles scherer could not but conclude that "... market concentration has a favorable impact on technological innovation in certaln situations. How much concentration is advantageous remalns to be determined. Obviously. there $1 \mathrm{~s}$ no general answer; the optimum depends upon the size of the overall market profit potential in relation to the cost of development in any given case"1). In a broader context scherer suggested that technological progress benefits from "... a subtle blend of competition and monopoly, with more emphasis in general on the former than the latter, and with the role of monopolistic elements diminishing when rich opportunities exist"2). So the 11terature on the subject up to the early efghtles tended to boll down to such general statements as "... there exists a market structure intermedlate between monopoly and perfect competition most conductive to technical change" ${ }^{3)}$. Taking into account the large Intellectual investment in this issue the general statements mentioned above might be somewhat disappointing to some of us. In particular as seen from a schumpeterian and classical economics perspective, as explained above, it can be stated that in advanced captralist economies:

- perfect competition Is but a rare occasion and not the rule;

- monopoly, in 1ts strict meaning, is found only for some products or processes during short pertod of time.

Consequently, it all could lead to the general but hardly discrimInatory conclusion that an advanced capltalist economic system is most favourable to technical change. Whatever the polltical economic relevance of such a conclustion might be $1 \mathrm{t}$ still 1 eaves us whout more detalled knowledge about the relationship between market atructure and innovation.

1) F.M. Scherer, 1980, p. 437.

2) 1 dem, p. 438 .

3) M.I. Kamien and N.L. Schwartz, 1975, p. 30. 
Recent contributions suggest that this relation between concentratLon and RED could be of a spurlous character because the explainIng factor can be found in the speciflc conditions of technologIcal opportunity within industrles. Hence, this technologlcal opportunity is associated wth both R\&D investment and concentration levels ${ }^{1)}$.

Such sector specific relations between concentration and RAD have also been found in a number of studies in the USA, which 11lusstrate the relevance of this point. Shrieves found posttive and signiflcant relations for levels of concentration and $R \& D$ for sectors productng consumer goods and producers of tertal inputs, and a postive but weak relation for producers of non-specialized goods. A marginally significant but inverse relation between concentration and $R \& D$ was discovered for the specialized durable equipment Industry ${ }^{2}$. Chappell et al. found Industrial concentration to have a strong significant positive effect on RAD in mechanical and electronic/electrical industries manufacturing consumer goods. Concentration has a weak effect on the RAD in producer goods industries and traditional consumer goods industries ${ }^{3}$ ). Angelmar found different results for research intensity and industrial concentration depending on different technological. opportunitles within sectors. In industrles with low RAD costs and low uncertainty of RAD, plus strong barrlers agalnst imitation (patents, trade secrets and property rights) industrial concentration is not necessary as there are sufficient incentives for innovation; if concentration already exists it will reduce the leve1

1) See D.C. Mowery, Market structure and Innovation: A critical survey, 1985, in which some recent studies on the lssue are revlewed; see also M.I. Kamien and N.L. Schwartz, 1982, pp. 58-64, and R.C. Levin, W.M. Cohen and D.C. Mowery, R\&D appropriab1lity, opportunity and market structure: New evidence on some Schumpeterian hypothesis, In: Amextcan Economic Revilew, Vo1. 75 , no. 2, 1985, p. 21 .

2) See R.E. Shrieves, Marketstructure and Innovation: new perspective, in: Journal of Industrial Economics, Vol. 26, 1978.

3) See H.W. Chappe1 Jr., J.T. Pletrowsk1, and R.P. W11der, RtD, firm size and concentration: Evidence from the FTC Line of Business Survey, in: Quarterly Journal of Business and Economics, Nol. 25, no. 2, 1986. 
of research investment. In Industries wth high RAD costs and high uncertalnty of RCD and no barriers, lacrease in concentration w111 lead to an Increase $1 \mathrm{n}$ research investment ${ }^{1)}$.

Therefore more frultul way to pursue could be found in the suggestion to pay wore attention to differences in technological opportunities, changes over time, and their consequences for the atudy of market structure and imovation. In particular, as e.g. Zuscovitch has stated, any attempt to 1dentify a market structure Which favours Innovation is an attempt to formulate a dynamic problem in static terms ${ }^{2}$. Then the study of market structure and Innovation could gain in a more detalled understanding of changes In each sector of the industry or market before returning: If posstble, to more subtle generalizations.

\section{Innovation_and_firm_a1ze}

The short review of euplrical findings on market structure and Innovation in the above w11 probably not arouse high expectations on the results of economic research into the adjacent and related Issue of firm size and innovation. Here also, many studies suggest an inverted $U$ distribution for innovation and firm size. However, there are also some studies which suggest some contrasting evidence. In short, one can confront three different groups of analyses on the relation between flrm size and Innovation:

- the widely accepted evidence of an Inverted $U$ distribution of R\&D Input and output over firm size which I will label the Scherer-varlant after one of 1 ts most prominent researchers;

- the Schumpeter insplred Interpretation of reseerch and Innovation concentration in large companies;

- analyses which, at firot alght, could well be synthesis of the two contrasting analyses mentioned above suggesting a $U$ shaped dlatribution of Innovation and firw size.

I wili brlefly discuss some studies whlch are exemplary for these different analysea.

1) See R. Angelmar, Market structure and research intensity in high-technological-opportunity industrles, in: Journal of Industrial Economics, Vol, 34, no. 1, 1985.

2) See E. Zuscovitch, The economic dynamics of technologies development, in: Research Pollcy, Vol. 15, no. 4, 1986, p. 176. 
A vast number of studies on the relationshlp between firm size and elther Innovative input or output suggests at least a non-11near1ty. Studies by Scherer, Mansfleld, Philips, Mueller, Freeman and others all polnt to this non-linearity. With the exception of the chemical industry there is 1ittle support for the hypothesis that Innovative Input and output increases with firm size beyond some magnitude ${ }^{1)}$. A well-known and prominent 1llustration of the findings of the humpack distribution of RaD intensity over firm size is found in Scherer's contribution. Scherer's theory and earlier research are well-known and have been discussed in the previous section. Also some of his more recent research supports his theory while it also offers some qualifications. Scherer maintains that small companies are still disproportionately important contributors to innovation as shown in diminishing returms in the relation between size and patents. However, it has to be acknowledged that large flrms contribute more than proportionally to total $R \& D$ expenditures ${ }^{2)}$. In his earlier writings Scherer stated that not only RAD output but also RSD input would rise less than proportionally to size once a threshold had been passed ${ }^{3)}$. His later findings apparently suggest some modification of earlier results.

Such findings on an inverted $U$ relation between size and innovation is partly supported in a recent study of Ettlie and Rubenstein who found that the introduction of radical new products is more than proportionaliy found within medium sized companies (between $\pm 1,000-10,000$ employees). The largest companies with over 45,000 employees in their population were unlikely to introduce radically new products ${ }^{4}$ ).

A study by Dorfman on Innovation in the computer and semi-conductor industries stresses the role small and new companfes have sometimes played as major innovators within these fndustries ${ }^{5}$.

1) See e.g. M.I. Kamien and N.L. Schwartz, 1975, and 1982, p. 18 ff; F.M. Scherer, 1980, p. $417 \mathrm{ff}$ and many other surveys.

2) See F.M. Scherer, Innovation and growth - Schumpeterian perspectives, 1984, PP. 222-239.

3) See 1dem, 1965, PP. 1103, 1104 and 1980, p. 420.

4) See J.E. Ettlie and A.H. Rubensteln, FIrm size and product Innovation, 1986.

5) See N.S. Dorfman, 1987. 
Contrary to most studies in this field Dorfman presented a more qualitative tudy combling analysis of rellevant technological developwents with changes in market structures. The study gives a differentiated picture of 1 innovation in five related industries: malnframe computers, minicomputers, computer printers, wagnetic dlak storage and integrated circults. In malnframe computers the present market leader IBM soon became the leading manufacturer. New and relatively amall companies concentrated on elther the very-hlgh-performance market nlche or the lower end of the market. In the other Industrles new and small companles played a more prominent role in particular at the early stages of technological development. Hovever, for each lndustry one has to recognize the complex setting and historical perspective of larger egtablished companies and entrants within sub-markets.

Scherer's and others' research findings on the relationship between $f 1 \mathrm{rm}$ size and Innovation have become 'conventional wisdom' amongst students of technological development, generally accepted and but rarely disputed. So far, but few have criticized the out come of a disproportionate distribution of innovative Input or output to slze. A marked dissident analysis has been brought forward by Soete ${ }^{1)}$. H1s alternative analysis 1.6 based upon RaD expendtures of US companies in 1975 and 1976 covering $95 \%$ of total company R\&D in the USA. This research generated results which contradicted accepted evidence of the size - research input relationship. From Soete's research 1 follows that very large compantes employing over 250.000 people had higher RCD to sales rat1o than the following slze classes. Also, R\&D expenditure 18 found concentrated In the largeat firms, ranked elther by amployment or sales. Furthermore, the results of regression analys $1 \mathrm{~s} \mathrm{in-}$ dicate that "... Innovation ffort, as measured by compeny 1 nanced RQD expenditure, tends to increase more than proportionate1y with f1rm size"2). There are differences between bectors due to

1) See L. Soete, 1978, Idem, Firm size and inventive activity the evidence reconsidered, in: European Economic Review, 12, $1979(\mathrm{a})$, and idem, size of $\mathrm{firm}$, aligopoly and research: $A$ reappraisa1, In: Reseaux, no. 35-36, 1979(b).

2) L. Soete, $1979(\mathrm{a}), \mathrm{p}, 337$. 
Industry specific circumstances but most industries studled are in favour of the Schumpeter hypotheses and the humpback distribution is found in only a few industries.

These findings cast some serlous doubt about the evidence of what has been described as "conventional wisdom" on the disproportiate relation between firm size and industrial research and development. Soete"s findings are, however, more in accordance with some of Scherer"s later findings on size and RAD Input.

The third approach, in which a v-form relationship between Innovation or R\&D and firm slze is generated, has only been introduced recently in two studies, one by Pavitt et al. and an other study by Bound et al. ${ }^{1)}$. These findings could contradict both the so-called Schumpeterian and the Scherer-like explanation. Pavitt's research is based upion a databank of over 4,000. Innovations which have been introduced in the past 40 years in the UK. The sectoral distribution of their sample of over 4,000 innovations colncides with the sectoral distribution of patents. Some conclusions to be drawn from this research are:

- There 1 s some evidence that the smallest companies and unfts of production, with less than 200 employees, and also the largest companies, with over 50,000 employees, have become more innovative in the period to which the study refers.

- There is an above average innovation intensity amongst large flrms, with over 10,000 employees, and growing Innovation intensity amongst smaller companles. (The plcture of the latter group is somewhat differentiated, but it holds for companles with a size between 100 and 500 employees and probably also for compantes up to 1,000 employees.)

1) K. Pavitt, M. Robson and J. Townsend, The slze distribution of Innovating firms in the UK: 1945-1983, SPRU-paper, 1985, idem, A fresh look at the slze distribution of Innovating firms, SPRU-paper, 1986(a), and 1dem, The size distribution of innovating firms in the UK: 1945-1983, in: Journal of Industrlal Economics, Vol. 35, no. 3, 1987; and $\mathrm{J}$, Bound, C. Cumins, 2. Grilliches, B.H. Hall, and A. Jaffe, Who does R\&D and who patents?, In: 2 . Grilliches, 1984. 
- Intersectoral compar1sons show that there 1 s considerable variation amongst sectors generating several distributions, which explains that the overall distribution is a result of three d1fferent trends. (Large firms domination, small firm domination and V-form distribution, each for a different group of Industries.)

In study by Bound, Grilliches and the1r colleagues the R\&D Intensity of about 2,600 us companies is studied and in particular very bmall and very large companies are found to be more RGD Intensive than average alze companies. However, their sample is strongly blased towards 11 firms which have been successful in RQD and interesting for investors.

As mentioned before the results of the empirical research so far have to be interpreted with utmost care. In many studies quite different Indicators for Innovation ranging from research inputs to Innovative output such as patents and tanglble Innovations have been applied. As far as the relation between firm size and R\&D Inputs 1 s concerned there is apparently some consensus that R\&D expenditures are concentrated in the group of very large companies and that these expenditures rise more than proportionally to the size of compantes. Regarding the output of research in terms of patents or Innovations the situation is st111 unclear.

Contributions by Pavitt and Bound and their colleagues camnot be aeen as a aynthesis of the other two approaches. On the face of the matter this could be concluded from adding both contrasting findings generating a stylized U-relationshlp. No matter how elegant such a solution might seem, it has certaln flaws. As mentioned above Pavitt et al.'s flndings suggest that at the level of Individual sectors of Industry several sorts of distributions of the relation between size and Innovation can be found. The overall U-relationship results from the interplay of Bize, Innovative activities and the intersectoral pattern. 
A possible way-out for further research could be found in a broadening of the scope. It has already been stated that the debate on market structure and innovation led to few satisfying results apart from the emphasis placed upon the 1mportance of technological opportunities as a key-issue on the present research agenda. Also, further research into the relation between firm size and Innovation could beneftt from more attention to e.g. technological opportunities within sectors of industry. Suppose that more of the same $k 1$ nd of econom(etr)lc research based on the well-known size classes and variables analyzing slightly different time-series and or data w11 probably not bring about completely new insights. In that case it might be useful to change our focus towards a more differentlated approach, in whlch innovative performance is analyzed in the context of sectoral differences and several categories of companies. Such an approach could also enable research to pay more attention to differences in technological opportunties for industrial sectors. Many authors have stressed technological opportunity as an important determinant of the relation between market structure, firm size and innovation. Technological opportunity is sometimes defined as the extent of basic scientific knowledge in the industry ${ }^{1}$. Levin et al, have included technological opportunity in thefr analysis in order to explain patterns of Innovation. They mention three dimensions of technological opportunity: closeness to sclence, external sources of technological knowledge and 1ndustry maturity ${ }^{2}$. It 1 e clear that technological opportunities vary amongst 1 ndustrles but also with time. Differences in the degree of Innovativeness of Industrles and the gradual but also uneven development of technology ttself causes technological opportunitles to differentiate.

1) See e.g. G. Dos1, 1984, PP. 92, 93 or R. Kapllnsk1, F1rm gize and technical change in a dynamic context, in: Journal of Industrial Economics, Vol. 32, no. 1, 1983.

2) R.C. Levin, W.M. Cohen and D.C. Mowery, 1985 and W.M. Cohen, R.C. Levin and D.C. Mowery, Firm size and R\&D intensity: A reexamination, in: Jourmal of Industrial Economies, Vol. 35 , no. 4. 1987. 
A 'wapping' of techmological opportunities, sectoral differences and company strategles has been introduced by Pavitt. The author has suggested taxonomy of technical change, categorles of firms and 1mdutrial sectors ${ }^{1)}$. Within this taxonomy categories of firms such as supplier domlnated, production Intensive and acience based flrms are set agalnst sectors of industry, technological developments and other characteristics buch as product or process lnnovatlons, ste of Innovating firms and forms of diversification. Ana1yses based on such an approach can lead to more differentlated knowledge about sectoral development, technological classifications of sectors and intersectoral patterns of technological change $^{2)}$

Freeman has introduced a somewhat simflar approach but more directed towards alstinction of industrites and the role of sma11 flrme in innovation. In Freeman's division of Industrles there are:

- Industries in which small firms make but little contribution to Innovation, elther absolutely or relacively, e.g. aerospace, motorvehicles and chemicals;

- industries in which small firms make a substantial contribution to Innovation, e.g. Instruments, electronics and textiles.

But also here few generallzations can be made becauge variations by branches of industry and other factars such as the position of the growth cycle of an Industry will have to be considered. In new Industries Freeman points out, in agreement with explanations stated e.g. by Dos1, Dorfman and Scherer, small Innovative firms can be Important but this role can gradually decrease as the Induatry enters into maturity and economies of acale are intraduced $^{3)}$.

A major achlevement of such attempts to understand industrial development and Innovation in the context of technological opportunitles 1 that innovation 16 not reduced to indicators such as R.D

1) See $k$. Pavitt, Sectoral patterns of technical change: towarda a taxonomy and a theory, in: Research Pollcy, Vol. 13, 1984.

2) See Iden, and L. Soete, Sectoral and technological taxonomies: an "integrative" analysis based on Innovation statistics, in: C.P.B., 1987 .

3) See C. Freeman, 1982, p. 143. 
or patents but that these Indicators are Integrated within a wider understanding of technological development and 1 ts consequences. A more detalled outline of a theoretlcal framework which enables a more dynamic and concrete understanding of technologlcal development and innovation will be presented in the next chapter. Here, It w11 suffice to draw some conclusions from the schumpeter debate for understanding technologlcal development.

Wntil recently the state-of-the-art of research on the Schumpeter controversy was somewhat disappointing. There has been some sort of consensus that both market structure and size of companies show an Inverted U-shaped distribution wh respect to Innovation. For the market structure many studies suggest that growing concentration is parallelled by a growing R\&D intensity upto a certain level after which RAD intensity grows disproportionately less than concentration. However, the relation between concentration and RAD intensity differs from sector to sector. Differences in technologIcal opportunity amongst sectors has been mentioned as the intervening factor which could explain differences in the relation between concentration and innovation for industrial sectors. For firm size and innovation the distribution is frequently seen as having a similar character. A non-11nearity between size and innovative output once a particular company size is reached, is accepted by many. It is thought that small companies play an Important role in the early stages of a particular technology, followed by a growing importance of large compantes in the further development of technology. Then, at a particular size both Innovative Input and output rise less than proportionally to slze. However, there is also some deviate evidence which suggests a I1nearity or even more than proportional growth of R\&D to size. And recent atudies discloge some emplrical evidence whlch suggests crosssectoral pattern of small and large company dominated process of innovation. But then again the pattern is fundamentally different at the level of individual sectors of industry.

Some recent contributions to evolutionary economic theory suggest a more fruitful analysis of technological development. In the next chapter I w11 return to these contributions. Here it w111 suffice to point at the growth of attention beling pald to technological opportunities both in the empirical and theoretical ifterature. 
A11 this suggests that fncluding technological opportunttes for several industrial sectors could enable the analysis of market atructure, firm aize and innovation to develop towards a more dymamic andyals. In particular if technological opportunity is operationalized adequately in order to understand technological development 1tself the analysis of the dynawics of innovation, market structure and f1rm size for sectors industry could complement 'across-the-board' analyses.

\subsection{CATEGORIES OF COMPANIES AND INNOVATION STRATEGIES}

In the above $1 \mathrm{t}$ has been concluded that widening the scope of research on the subject of market structure, flrm size and innovation could well complement more traditlonal research. The inclusion of technological opportunity, In particular if understood as a way to understand technological development itself, could provide useful insights for further study. But also a further categorization of companies can lead to a more concrete understanding of Innovation and Industrial development. The mere recognition of relevant differences between categories of companies 1 s superfor to the crude neo-classical theory of the firm in which a company is reduced to a production function. It also colncides with some recent developments in industrial economics deviating from the traditional school based upon Baln's 'structure-conductperfowance'-approach, In which there had been so little attention to different performances of companies. Since the late seventies there has been a growing atcention to strategic aptions and categorles of companies. Stressing the role of both different categortes of companies and different strategles and objectives enables are dynamic analysis of industry evolution. In short, the more static relation between structure, conduct and performance 1 replaced by more dynamic approach in which there are feedback effects from performance and conduct to otructure i).

1) See also M. Porter. The contributions of industrial organizaton to strategle management, in: J.B. Barney and W.G. Ouchi (ed.), 1986 and $P$, van Cayseele and $H$. Schreuder, De economische lnbreng in de strateglebepaling van ondernemingen: een overzicht, 1988. 
In thls section I wll pay attention to some attempts made to differentiate between groups of companies and thelr innovation strategles. Before discussing such categorlzations I w11 first brlefly discuss some aspects of organizational changes of companies in modern capitalism and corporate innovation strategles.

\section{Organizational transformat 1ons and innovation}

In modern capltalism one observes wide varlety of companies from extremely large, multinational, companies to small companies with only a few employees. The growth of both compantes and plant-size has been recognized as an Important feature of capltalism ever since the classical economists. In particular the growth of compantes has been subject to a continuous debate on (In-)efficlency and size. In that context organizational changes within companies have been discussed as 'solutions' to problems related to in-efficlency following company-growth.

Such organizational changes are also relevant for undergtanding innovation strategles in modern companies. These organizational and decision-making aspects of Innovation strategles are frequently discussed in the literature on large, mult1-product companfes with a multi-divisional structure. In seminal work by Chandler and W1111amson, but also in some less wel1-known neo-Marxlst contributions, different company and management structures are 1dent1fled 1 ). The analysis of Chandler stresses the outlived character of the so-called unitary, departmentalized, U-form organization of - large company with respect to major issues in its strateglc declston-making. The alternative was found in the so-called form, multidivisional, organization in which strategic and operatlonal dectsion-making are separated at different levels. At the top level, the general office is Involved in coordination and evaluation of strateglc deciston-making. Operational dectsion making takes place at a lower level of separate divisions.

1) See A.D. Chandler Jr., The visible hand: the managerlal revolution in American business, 1977, A.D. Chandler Jr, and H. Daems, Managerial hierarch1es, 1980, and 0. E. Wlllamson, 1975, and S.H. Hymer, The multinational corporation, a radical approach, 1979 and M. Aglietta, 1979. 
The clasalcal U-form organization with vertically integrated divisions can st11 dominate the group of medium sized companies. It: structure is most sutable for decision waking on familiar problems within a non-diveraffled company ${ }^{l)}$.

In this context two interesting neo-Marxist contributions, by Hywer and Aglietta, are worth mentioning. Hymer has paid extensive attention to the role of large, multinational, companies and their organizational change ${ }^{2)}$. Aglietta has been able to take the argument somewhat further and present an interesting concept of the corporation as a global system ${ }^{3)}$. Both authors founded their theorles of organizational change of companiles on Marx's theory of concentration and centralization, but they have integrated elements of modern theories of organizational change of compantes in their respective theories. Hymer presented a theory of the evolution of the corporation at different stages. In short, these stages have developed from the workshop, the factory, the natlonal. corporation, the multidivisional corporation to the multinational corporation. Aglletta has amalyzed changes in corporations from the former centralized, U-form, company to the decentralized multi-divisional company into a new stage of a centralized and global system.

Both typologies of corporate change can be integrated into the following framework.

Some of the 19th century 'single product-line' manufacturing compantes gradually developed into the large company with a few functonal departments and a separate head-office. Such companies have been descrtbed by Hywer as 'national companies', and by and large the matn features of these companies colmcide with Chandler's U-fora. Through Internal and external growth (concentration and centralization) again some compantes evolved into multidivistonal, diversifted, companies in which the organtzational top-etructure changed from a head office into a general of fice. Kany management

1) See G.J. Sutton, Economics and corporate strategy, 1980, pp.

2) See e.g. S.H. Hymer, 1979.

3) See H. Aglietta, 1979. 
tasks were decentrallzed and commisstoned to diviston-1evel. In this structure the general office is engaged in strategle planning and control of divislons based upon financlal criterla 1 . These companies are usually multidfvisional, Chandler"s M-form, but also mult Inational.

Hymer mentioned the planning of the product cycle as an essentlal feature of this modern, multidivislonal, corporation. Planning of the product cycle involves the coupling of several phases of production, such as R\&D, manufacturing and marketing. The development of degrees and patterns of coupling of such phases of production reached its highest level of control in the modern multidivistonal and multinational corporation. The increase in information flows Is a reflection of the importance and interaction of product development and marketing in the M-form company ${ }^{2)}$.

Aglietta has taken the notion of intensified integration of Information flows somewhat further, introducing the concept of the corporation as a global system evolving from the multidivisional structure ${ }^{3)}$. In this development there is a change, an organizational trangformation, back to organizational centrallzation although under different conditions than in the situation of the $\mathrm{u}$-form company. The present transformation of the organizational structure 1s, according to Aglletta, a movement back to central1zation but based upon automated information processing and overall production control. This new organizational structure is pletured as a star-fort compared to the divistonal atructure in the form of a pyramid. The central control unit is found in the centre

1) Following Ansoff this strateglc declsion-making ls directed towards:

"- monitoring the environment for changes and searching for attractive product opportunitles;

- consideration of allocation of resources between current operations and possible future opportunities;

- evaluation of competitive advartages, long-term potential and possible jolnt effects (symergy) of opportunities;

- coping with potentially antagonistic objectives";

see Ansoff op. c1t. In N.M. Kay, The innovating firm, 1979, pp. 54, 55..

2) See S.H. Hymer, 1979, p. 151.

3) See M. Aglietta, 1979, pp. 257-266. 
coordinating and programing all company-activities. Furthermore, all elements of the company are interacting with each other. This new system of organization enables the company to set up semiautonomous groups in order to improve the external "sensitivity" of companiles. Whthin this system the development of combunication, autowation of routine managerial tasks, improvement of planning and budgetary thods and production contral are compulsory. Around these corporations there is 'a network of subcontracting' wth legally independent companles. These firms produce no comodIties in the strict sense but intermediate products within a wder production process. Although legally independent they can be considered as a part of the production praciess of larger companies ${ }^{1}$.

Both Hywer's and Aglletta's contributions present some valuable thoughts on organizational transformetions of corporations and the differentiation of capital. The distinction of companies into national, not widely diversified companies, and multidivisional, multinational, companies and small, economically dependent but not legally integrated firms appears to be helpful.

The remarks mede by Hymer about the growing integration of information flows from and to all phases of the product cycle stress the Importance of organisational control within large multi-divislonal companies. This growing integration is also stressed in Aglietta"s concept of the corporation as a global system. The attention pald to integration, overall production control, automation of lower-level managerial tasks is worth mentloning. Also the interrelation of companies and how 1 t can effect technological change is relevant ${ }^{2}$. In that perspective the relation between large multidivistonal companles and small sub-contract1ng firms is of 1mportance. The present trend in sub-contracting and co-makership, widely discussed in the popular business press, supports the view of an economic and often technological 1 ink between companies. In that case large companies outsource non-critical parts of

1) See 1dem, P. 220 .

2) See e.g. J. Hagedoorn and J. Schot, Co-operattan between companies and technologleal development, 1988 and the literature
mentloned. 
thelr production and small firms supply interwediate products or servlces often within modern "Just-in-time"-lines of production. In a sense this is a trend which goes against vertical integration In the formal sense, but in practlce there $1 \mathrm{~s}$ a form of "quasi" integration if suppliers depend on a small number of procuring companles .

\section{Innovation- and corporate strategies}

It w11 be clear that the transformation of compantes into different categorles is related to Innovation strategy and changes of strategy. Already Schumpeter discussed innovation as a change from existing routines in a company. This notion of routine and innovation as a change of routine is also found in the evolutionary theory of Nelson and Winter. It 1 s introduced by them to describe regular and more or less predictable patterns of company behavlour. A routine is defined as all conduct which $1 \mathrm{~s}$ "... regular and predictable (...) especially if we understand that term to include the relatively constant dispositions and strateglc heurlistics that shape the apprasch of a firm to the nonroutine problems 1t faces." 1 . Routines include characteristics of firms regarding several pollctes for the organtzation of production and innovation strategles, manpower, Investments, et cetera, the so-called operating characteristics. Compantes follow routines while they are operating in the market and when they are adapting their internal strategies to their environment. These routines serve as $a \mathrm{kind}$ of organlzational memory, representing the exlsting capab111ties of company. Nelson and Winter stress that "... flrm with an estab11shed routine possesses resources on which it can draw very helpfully in the difficult task of attempting to apply that routine on a large scale. Because the creation of productive organizations is not a matter of implementing fully explicit blueprint by purchasing homogenous inputs on anonymous markets, a firm that is already succesful in given activity is a particularly good cendidate for being auccessful with new capacity of the same sort" ${ }^{2}$ ).

1) R.R. Nelson and S.G. Winter, 1982, P. 15, see also R.R. Nelson, 1987, pp. $21-23$.

2) 1dem, 1982, p. 119. 
Therefore flrms are wally beter equipped to do wore of the same than to change thelr strategies on one of theli characteristics. Changes in routlmes under uncertain conditions or just new comblnations of already tsting routines can be described as innovationd in the Schumpteriam sense. There is also some similarity between future and present behaviour of companles because the routines that flrms have employed In the recent past wll have a rather trong tie to routhes applled in the near future.

Innovations are not only characterized as a change in the existing routines, but Innovations can also emanate from problems and irregularitles thin these routines. Answers to the questions being ralsed by these problems are probably to be found in a change of prevalifing routines or in carrying out of new comblnations, in the Schumpeterian sense.

Wew combinations ay found through elther existing routines whlch had not been combined before or a combination of existing routlues with new subroutines. Nelson and Winter stress that for the Incorporation of existing routine as a component of Innovarive routines it wolld be useful if two conditions are satisfied:

- The routine has to be rellable in order to ensure that existing routines do not cause new problems in their new setting*

- The new application of the existing routine should be unambiguousiy applicable.

"These two conditions suggest an important quallfication to the general notion of an opposition between routinization and innovation. Rellable routines of well-understood scope provide the best components for new combinations. In this sense, success at the innovative frontier may depend on the qual1ty of the support from the 'clvilized' reglons of established routine."1).

Although innovation can largely be characterlized by a fundamental uncertalinty about the results, the search process involved can to a large extent be described as 'routinized". Nelson and Winter adopt the framework of the theory of heurlstic search for a better undertanding of the relation between routines and innovation. As a definition of heurlstic they adopt Mewell, Shaw and Simon's definftion stating that a heuristic is "... any principle or

1) Ibldem, p. 131 . 
device that contributes to the reduction in the average search to solution" ${ }^{1)}$. Search strategles of flrms adopt certaln procedures for the screening of ROD projects. These RSD strategles consist of ". a quasi stable commitment to a particular set of heuristics regarding R\&D profect selection... 2). It is possible to recognize certain RED strategles that dominate particular sectors of the economy but the total number of research projects for an R\&D organization is in theory that large that in practice certain cholces have to be made. Therefore, as Nelison and Winter rightly state, most firms will limit themselves to "...strategles which Involve a precommitment to one or a small number of classes of RAD projects each of which has a certain similarity of broadly defined targets, procedures for reaching these targets, and $R \& D$ resources required." ${ }^{3)}$. Even if these search strategies consist of more or less well described set of activities and declsion rules, accordIng to Nelson and Winter, "... firms cannot hope to find optimal strategles"4). However, even these non-optimal pollctes are of course aimed at a positive influence on the firm's profitability.

The understanding of Innovation strategles in terms of routtnes and heurlstics parallels theorles on strategic declstion-making on innovation and $R \& D$ priorities. It is accepted by many that in large companfes top-leve1 deciston-making on corporate R\&D budgets is generally based upon consideration of resources, not on projects. This resource-consideration instead of component projects, together with a routine of R\&D funding, leads to quasi-stable RdD decision-making within large companies ${ }^{5}$.

Kay has mentloned four general features of corporate RAD resource allocation:

- allocation $1 \mathrm{~s}$ based on subjectlve rather than objective dec1sion rules, applying rule of thumb methods rather than optimlzation techniques;

1) Ib1dem, p. 132 .

2) R.R. Nelson and S.G. Winter, In search of useful theory of Innovation, 1n: Research Policy, Vo1. 6, 1977, p. 52.

3) 1b1dem, P. 5.5.

4) 1 bidem, P. 55 .

5) See also EIRMA. The role of RGD in the Innovation process, 1982 and Idem. How much RGD?, 1983, and R. Coombs, P. Savlotti and V. Walsh, Economics and technological change, 1987, Ch. 3. 
- there are stable managerial preferences for allocation;

- the corporation behaves as an open system in which RAD at the functional level can influence managerial preferences;

- decision-making is rational in the sense that companies learn to chose an appropriace level of RSD in order to survive ${ }^{1)}$.

The practice of inter-subjective declsion-making against a background of stable routines of $R \& D$ fwnding is quite contrary to management declsion-making supported by "scientific" methods. The inposslbility for companles to overcome uncertalnty in technologIcal development by 'objective' technology forecasting methods is frequently stressed ${ }^{2)}$. Corporate RaD decision-making at top level can be expected to be more of a general comitment to a satisflcing level of resource allocation. Consequently decision-making at lower levels of management has to be more related to specific problems and component Innovation profects. This level is found wthin the divisions or central RaD institutions of large compantes $^{3)}$.

So far most attention has been pald to transformations of larger companles and their Innovallon strategles. Small and medium sized compantes have been mentioned, but only incldentally. Much of the literature on Innovation strategles and related issues deals with large, In particular, the very large companies. This particular attention for large companies is understandable as they present a group of companies for which the process of deciston-making and existing procedures are more readily studied.

But, as mentioned in previous sections, innovation is probably not only matter of the largest companies. Small and medilum sized companles do pull thelr weight although it might vary from industry to Induatry. Even with regard to R\&D activitles some small and medium sized flums play an active role. Freeman has mentioned three categorles of small and medium sized firms for which RuD is essential to thelr existence:

1) See N.M. Kay, 1979, P. 91, 92, and R. Coombs, P. Sav1ott1 and v. Walsh, 1987, p. 59 .

2) See e.g. C. Freeman, 1982, p. 168; N.M. Kay, 1979 and 0. Grandstrand, Technology, management and markets, 1982.

3) See e.g. EIRMA, $1983, \mathrm{P} .67$, and R. Coombs, P. Saviotti and V. Walsh, 1987, Gh. 4 . 
1. Firms which have recently started to develop of explott a new Invention and for which a high research intensity can be expected. The research intensity will probably fall after successful exploitation of the invention.

2. Highly speclallzed, often research intensive, firms which concentrate upon narrow fields of technology.

3. "FIrms struggling to survive in industries in which new product competition makes RSD increasingly necessary. Here small firms can either pursue to survive with a so-called sub-threshold RaD effort, or rely on cooperative research or take high risks with an amb1t1ous programme"1).

In the foregoing it was stressed that large, medium and small companies all play a role in generating innovations. Their role in research might differ, there are sectoral differences and technological opportunity is to be incorporated in studies to achieve a better understanding of many 1 ssues. If these differences are recognfied, then the scope of research will be broadened constderably.

It would be broadened even further if various innovation strategles, some open to several groups of companies, are Incorporated. E.g. Porter, and also Nelson and Winter, discuss technology strategles in the dichotomy of technological leadership versus followership or innovative and imitative strategies ${ }^{2}$. Freeman had already taken the issue somewhat further in recognizing several Innovation strategies. Based upon Freeman"s contribution one can distinguish six alternative ldeal types of Innovation strategies $^{3)}$ :

The offensive Innovation strategy which is eitied at achleving both technologlcal and market leadership through quick Internal techno$10 g$ ical diffusion, keen exploitation of new combinations or combination of both. An offensive atrategy encompasges internal RAD factlities, Information processing ablittes and matketing factl1ties.

1) C. Freeman, 1982, pp. 133, 134, see also R. Rothwe11, 1986, pp. 125-127.

2) See M.E. Porter, Compet1t1ve advantage, creating and sustaining superior performance, 1985, PP. 181, 182, and R.R. Nelson. 1987, pp. 41-43.

3) See C. Freeman, 1982, pp. 170-186. 
Defensive strategles do not imply a complete ignorance of Innovative activities but companies following such strategles are more rlsk-averse and at some distance from the radical innovating companies. Defensive strategies by large companies can be expected In particular in mature ollgopolistlc market structures. Such defensive strategles enable companies to "keep up with the game" but 1mtative companies are normally lagging at considerable distance from the leading companies. In order to compete with Innovating companles 1 mitators have to rely on speciflc advantages for some factors of production, or concentrate at the lower end of the market.

For many large multi-product compantes thelr overall innovation strategy 111 be a mixture of both of fenstve and defensive, and perhaps initative, strategles for different lines of business.

A dependent strategy is usually of some sort of subcontracting character, in wich no initlative toward innovation is taken unless it is done by customers.

Iradtional strategles are followed by companies for which innovation is not compulsory due to speciflc market circumstances, e.g. In handicrafts.

Opportunist strategles reflect the search for particular market niches by so-called imaginative entrepreneurs.

The actual market structures and technologtcal opportunities are too complicated to make a drect linkage between size of companies and innovation strategles. Also, the character of strategles will differ between sectors. E. $g$. a defensive strategy in a sector with many technological opportunitles such as in the microelectronics industry or in other "high tech' sectors is intrinsically more offenstve than an offensive strategy in an Industry with iftele technological opportunity. In other words, the set of alternative strategles and thelr concrete substance 1 s medlated by sectoral and technological clrcumstances. Depending on both structure of the Industry and technological opportunity a number of strategies are open to all companies. As such classification of innovation strategles and slzes of companies does not render predictive statements but it can be useful in describing different company behaviour in a particular industrial setting. Although not identical the approach chosen has certain features in common with the analysis of 'strategic groups' in strateglc management 
studies ${ }^{1)}$. In particular multivartate analyses of strateglc groups with reference to size of companies provide somewht similar attempts to bridge the gap between industry and company-level analyses. In this study alternative innovation strategles could be seen as 'strategic groups' In relation to malnly one particular sspect of business strategie, 1.e. Innovation strategy.

3.7 AN ANALYTICAL FRAMEWORK FOR THE ANALYSIS OF INDUSTRY STRUCTURES AND INNOVATION

Having reviewed relevant theories and research in the foregolng, elements of these different theoretical contributions and conclusions from empirical research w111 have to be mediated into an alternative and more coherent analytical and conceptual framework.

In neo-Marxist political economics a rather static theory of monopolization has been at the forefront of this particular economic paradigm. Sweezy's contributions are typical for this approach in which companies are divided into two separace classes. One group is the group of small and probably also medium sized companies. The other group consists of so-called monopoly capltal also labelled as ollgopolles, large companies or big business. This theory shares 1ts dichotomy with Galbraith's, partly Schumpeter inspired, approach. A major difference between both theories is that in the theory of monopoly capitalism a slower rate of the introduction of Innovations is assumed while Galbratth assumes that very large companles and concentrated markets are a stimulus for innovation. However they share their neglect of the dynamics of captealism through the effects of creative destruction. Both contributions arrive at almple dichotony of large versus sma11 compantes which is too simple for analytical purposes. The same holds for theories in which companies are aeen as either small, efficient and Innovative or large, Inefflelent and non-1nnovative.

1) See e.g. J. McGee, Strategic groups: A bridge between industry structure and strategic management, 1985 and K.J. Hatten and M.L. Hatten, strateglc groups, asymetrlcal nobllity barriers and contestability, 1 : Strateglc Management Journal, Vol. 8 , 198.7 . 
In between the two extreme positions there are number of theoretical nuances. Some state the advantages and disadvantages of both small and large companies in general, in doing so they present both sides of the coln. If these (dis)advantages are related to sectoral differences, e.g. small companies face substantial disadvantages in $\mathbb{R} \& D$ and capltal iatensive sectors, then the argument is taken some steps further.

Within the neo-Harxist school a deviate approach stresses the dynamic analygis of different categorles of companies without a structural differentiation of companies into e.g. a structural hierarchy of proflt rates. In that context competition between companies is related to both growth of industrial sectors and companies. Monopoly is seen as a transtent feature of Innovation which is not directly related to size.

As demonstrated, many recent contributions to Innovation theory and research stress the interrelatedness of industry structure, f $1 \mathrm{rm}$ size and technological opportunity/maturity. This dynamic aspect provides a bastc assumption for the analytical framework from an evolutlonary perspective.

In the following chapters, in partlcular in chapter 5 , the role of size and Innovation, changing industry structure, and Innovative performance will be analyzed for the international process control Industry.

From the 11terature, discussed above, some general hypotheses are to be drawn for further empirtcal analysis:

- Rapid technological development in an industry will lead to high average RAD Intensity, as the induatry reaches a level of maturlty 1 to structure w11 become more concentrated (e.g. Neloon and Winter).

- In new flelds of technological development innovative companfes w111 obtein temporary olfgopolistic positioms, as the technology and the Industry matures one w11 find atable oligopolistic structures (Dos I).

- The relation between Innovation and both Industry structure and EIrm size can be characterized as an inverted U-relationship, innovation Increases with size of firms and Induatrial concentration upto particular level after which there is a relative decline. Small companies are disproportionately important to Innovation (e.g. Scherer). 
The third set of general hypotheses has been subject of a substantlal number of emplrical studies. No conclusive evidence has been found, but for firm size and innovation three contradicting' results have been generated:

- The relation between size and R\&D output is of a stylized inverted $U$ - relationshtp (Scherer and others).

- R\&D Input Increases more than proportlonately with firm olze (Soete and Scherer).

- The relation between slze and innovation is U-shaped, but there $1 \mathrm{~s}$ large inter-sectoral variation (e.g. Pavitt et a1.).

As innovation is operationalized quite differently in many studles, elther through input or output indicators, it seems sensible to analyze innovative performance applying a number of indicator . In the following chapters some indicators of Innovation such as RQD-Inputs, diffusion of best practice technologies, and share of new products in company turnover w111 be introduced.

Many studies suggest that technological opportun1ty is an fmportant intervening factor. In the empirical parts of this study the process control equlpment (p.c.e.) Industry and 1ts companies will be studied for their technological performance within the perspectives of a particular field of technology. By-and-large the technological opportunity 1s, although not 1dentical, relevant to all companies. To study this technologlcal opportunity it can be helpful to achleve in-depth knowledge of technologlcal developments relevant to the understanding of Inmovation and technological change in the particular sector of industry. Studying technologfcal opportunity agalnst the background of technologlcal change In an Industry provides complementary information for the Interpretation of indicators of Innovation.

In the previous section it was explained that a differentiation of companies to alze and their Innovation strategles would enable a more subtle analysis of industry structure and technolog1cal development. From the foregoing it is possible to derive the following categorles: 
- mall or medtum sized companifes which serve as subcontractors;

- small (extating or new) or medium sized 'single product line' companies;

- large companles with a small numbers of divisions;

- very large. multidivisional and multinational companies.

The actual alze of these categories is to be determined in the light of the sector in question. Too of ten the debate about size has been mystified by fabricated size-categories which are of 1ittle relevance to the actual distribution. In other words, medium sized in one industry can easily turn out to be large in another.

Innovation atrategles of these categorles of compantes are to be understood as a mixture of existing routines and implementation of changes in routines. In larger companies search strategles have become routinized with stable commlments to $R$ aD and areas of Innovation. Alternative strategies range from offensive, defensive, Imitative, and dependent to opportunist.

There $1 \mathrm{~s}$ hardly any reason to expect that, with few exceptions, particular innowation strategles will only be pursued by certain categortes of compantes exclusively. A dependent, subcontracting, strategy is probably most relevant for some smal1 and medium sized companies. Almost by definttion, an opportunist strategy can be expected from small and new companies. Traditional strategles are only relevant for some industrles and from common sense one can expect that in those Industries small and medium sized companies w11 follow such a strategy.

The other strategles mentioned above are less discriminatory for categortes of compantes according to size, beforehand. As a cort of null hypothesis it can be expected that offensive, defenstue and imitative strategles are followed by companies in all size-categorles in a particular industry. 
In the foregolng I polnted at the thorough understanding af technologlcal development itself that Maxx demonstrated in his anelya18 of captalist development. Aso Schupeter, although not to comparable leve1 of deta11, emphastzed the understanding of innovation beyond what it usually found in economic analyses of technalogical developwent. Following this tradtion of serlous attempts to pay profound attention to the importance of technology, some recent interesting attempts have been made to analyze technologlcal development as an evolutionary and dynamic process in which both technology and economic development influence each other. In such an approach technologleal development is analyzed as demonstrating far-reaching revolutlonary changes which fter successul introduction are followed by more incremental evolutionary changes. A central element in evolutionary theorles of technological development is this attention pald to technological change as proces of accretion. E. 8 . both Rosenberg and Sahal stress this cumulative aspect of technology as a historfcal process in "... a series of smaller and highly tentative steps" 1 . In come analyses wich stress the evolutlonary character of technolog 1 cal development a new conceptual framework 1 in introduced in which concepts such as technologlcat paradigm, cechnologlcal regime, basic deslgn and technological trajectorles are intraduced. such concepts can be applied without a clear definition and their '1cose' Interpretation makes them extremely wel1-sulted for suggestive descriptions of technological development. They share this partfcular feature with e.g. the Marxlst notion of forces of production. However, a sicticter interpretation of these concepts and

1) N. Rosenberg, Factors affecting the diffusion of technology, 1n: 1dew, Perspect1ves of technology, 1976, PP. 192, 193; see also D. Sahal, Patterns of technological Inmovation, 1981, p. 37. where it is stated that technological development 18 rather evolutionary, whereby radical break-through point are generally made possible by numerous minor innovations. 
a clear distinction of different levels of abstraction can in my oplnion, offer sone frultful clarifications on the role technologlcal change plays in economic development. Moreover it will enable a clearer 1dentification of technological aspects of the development of the forces of production.

Before I discuss these concepts and submit a theoretical framework 1t would be useful to explore some 1deas on what 18 meant by "technology" In the context of this study. I w111 refer to technology a a particular aspect of what 1s labelled as the forces of production in Marxist theory. A useful definition has been suggested by Dosi in which technology 1 s described "... as a set of pleces of knowledge, both directly "practical" (related to concrete problems and devices) and 'theoretical' (but practically applicable although not necessarily already applied), know-how, methods, procedures, experfence of successes and fallures and also, of course, physical devices and equipment."1). In my view technology differs from craft based technique in 1 ts theoretically mediated character and from sctence in its more practical and applied character. In practlce there 16 a 'grey area' between craft based expertise and theoretically mediated technology. Following Whitley technologlcal research can be differentiated Into:

- trial and error experimentation based upon conventional judgements and not upon deduction from general laws and principles (this trial and error experimentation is, in my apinion, an example of the 'grey area' between technique and technology);

- applied research on partlcular artefacts or systems redescribIng practical problems to the extent that they can be analyzad, wth 'established sclentiflc knowledge" leading to feastble practical solutions; and,

- theoretically 'backed' technological research which generates some general underatanding of causal relattonships ${ }^{2}$ ).

1) G. Dos1, Technological paradigms and technological trajectorles, in: Research Pollcy, Vol. 11, no. 3, 1982, PP. 151, 152; see also 1dem, Technical change and Industrial transformation,
198.4 .

2) See R.D. Whitley, Types of technologlcal research and their impact on occupational practices, 1987, pp. 4-6. 
In that sense there is no general model of technological change golng from science to technology to Innovation. As, en. Thirtle and Ruttan have explained sclence and technology orlented research are "... two parallel but interacting paths"1). For some Industrles craft based expertise comblned with trial and error expermentation such as in mechanlcal englneering w11 generate technical change. In others technological development is characterized by the application of established or new theoretleal understandIng. Although there are st111 some obvlous reasons for differentlating between technology and sclence, it cannot be dented that, as Marx already stressed, one of the characteristlcs of modern capltalist societies is the growing interrelation between applied sclence and technology in so called science based industries ${ }^{2}$.

Somewhat simflar remarks are to be made about the interrelation between technology and innovation. Following a well accepted definition innovation is the commercial introduction of a new product or process. An innovation could therefore result from elther technological research or craft based inventive activities. If one abstracts from innovations resulting from craftmanship then science, technology and Innovation could be seen as overlapplng, Interacting, but st111 partly autonomous, "stages" In changing the materlal world, ranked in order of market-related activity.

In the following sections I will introduce conceptual and theoretical framework which enables the analyols of technological development at different levels of abstraction. Concepts which figure in section 4.2 are technological paradigm, basic design, key-element, technologlcal trajectorles and generations.

In order to limtt the abstract character of guch a treatlge these concepta will be applied in the analysis of technological developments which are relevant to understanding the core-industry of this study, the sector in which information technology la transformed into process control equipment and control systems ${ }^{3}$.

1) C.G. Thirtle and V.W. Ruttan, The role of demand and aupply in the generation and diffuston of technical change, 1987, p. 7 .

2) See e.g. C. Freeman, The economics of 1ndustrial innovation, 198.2 .

3) The empirical data on relevant technological developments are largely based upon $J$. Hagedoorn, $p$. Kalf and $J$. Korpel, Technological development as an evolutionary process - the case of information technology and process control equipment, 1988. 
Technological developments 1 in process-, 1nformation-, and process. control technology are nalysed as changes within or changes from existing technological paradigns. Particular attention is paid to developments elosely linterlocking all three flelds of technology. Th1s part of the analysis $1 \mathrm{~s}$ st11 at a level of considerable generallty. The analysis 11 become wore epecific with the introduction of bastc destgns and key-elements as a further concretization of technological development, In this case the analysis of trends in process control technology. At the most concrete level of analyels technology is analysed in its development along trajectortes leading to subsequent generations of both control devices and control systems. In short: section 4.2 pletures technological development an evolutionary process with changes both within or from technologlcal paradigms and their materialization in basic deslgns and technological trajectorles.

The next section bullds upon this concrete understanding of technological development connecting the analysig of technological change as an evolutionary process with diffusion. From that perspective diffusion is not a static phenomenon, the spread of a particular unchanging technology, but diffusion is a part of the evolution in technological trajectories. Some recent theoretical contributions will be confronted with more traditional theorles of diffusion. Elaborating upon some criticlsms on traditional research the consequencces of an alternative approach is shown in the empirfcal analysis of patterns of diffusion of Information technology in process control. Th1s will be studied in terms of changes in the relative fmportance of several generations of process control equipment and systems. In section 4.3 empirical findings on diffusion of Information technology in process control are analyzed in the context of a survey of the international Industry of process control equipment manufacturers. The findings of this survey w11 be studied extensively in the next chapter.

The present chapter 'bullds a bridge' between the foregolng chapters, in which theories and research on technological and Industrial development were dlscussed, and the next chapter where a concrete Industry and innovative perfomance of different categorles of compantes are discussed. 

NOLOGY AND PROCESS CONTROL.

In the following paragraphs I shall proceed from a general analysis of cechnological development in process control, information cechnology and process technologies to more specific analysis of technological trafectories in process control. At an intermediate level of detall technological development can bo analyzed in terms of changes of so-ealled bastc destgns. The analysis of partlcular flelds of technology within a theoretlcal framework enabling descriptions at different levelg of detall w111 concentrate upon both cumulative and divergent aspects of technological development. Such an analysis in which technology itself is studied provides some tools for the measurement of technological development which can complement more well-kmown indicators such as RSD Inputs and outputs and patents.

Technological paradigms in process technologies information technology_and_process_control

The first concept I will define is technologleal paradign. This notion is applied by a growing number of scholars from different disciplines such as economics, soclology, phllosophy and history of technology ${ }^{1)}$. In applying the notion of paradigm I refer to its meaning as a body of knowledge and practlces which serves "... for a time implicitly to define the legitimate problems and methods of a research fleld of succeeding generations of practioners" ${ }^{2}$ ).

1) See e.g. G. Dosi, 1982, G, Gutting, Paradigms, revolutions and technology, In: $R$, Laudan (ed.), 1984, H. van den Belt and A. R1p, The Nelson-Winter-Dos1 model and synthet1c dye chemistry, In: W.E. Bifker, T.P. Hughes and T. PInch, 1987, C. Freeman and C. Perez, The diffusion of technical innovations and changes of techno-economic paradigm, SPRU-paper, 1986, C. Freeman and $L$. Soete, Information technology and change In the techno-economic paradigm, in: C. Freeman and L. Soete (ed.), 1987, and N. Clark and C. Juma, Long-run economics, an evolutionary approach to econom1c growth, 1987.

2) T.S. Kuhn, The structure of sclentific revolutions, 1974 (1962), p. 11 and 1 dem, Second thoughts on paradigms, 1n: 1dem, The essential tension, 1977. 
Athough one has to be careful with analogies a technological paradign can be 1 terpreted as the technology related counterpart of Kuhn"s sclentific paradigm. It stresses the role a disciplinary matr $1 x$ or a comunity of practloners "... with similar education and professional initlations ..."1) plays in definling a fleld of technology " Following Kuhn Dost has defined technological paradigm as "...'model' and 'pattern' of solution of selected technological problems, based on selected principles dertved from natural sclences and on selected material technologies; (...) a technologlcal paradigm embodies strong prescriptions on the directions of technical change to pursue and those to neglect" 2 . Although natural sclences are important to the bullding of technological parad1gms it has to be stressed that soclal sclences can also play a role, in particular wh respect to organizational aspects of production technologies. Within technological paradigms rules bullding both negative and positive heuristics are formulated to stimulate research in certain directions. Therefore technologlcal paradigms have a strong 'exclusion effect' as they are foctused on certa1n directlons, explofting only particular technological possibilities. Also, a technological paradigm relates "... to generic tasks to which 1 t is applied $(. .$.$) , to the material$ technology it selects (...), to the physical/chemical properties It exploits (...), to the technological and economic dimensions and tradeoffs $1 t$ focuses upon $(. .)^{\prime \prime 3)}$. Hence, technological paradigms are to be understood as basic bolles of rules steering the process of search within technologically mediated knowledge. As in octentiflc paradigms most of the research within a well developed and 'mature' technological paradigm is aimed at solving 'puzzles' with existing tools. New paradigms emerge from the existing paradigms which are confronted wth their boundarles when questions can no longer be answered wthin the existing body of knowledge and practice. Then, theorfes, new rules and practices have to be formulated and developed, It will be clear that the closer the achlevements of a paradigm Interact with the research

1) 1dem, $1974(1962), \mathrm{p}, 175$.

2) G. Dos1, $1982, \mathrm{p} .152$.

3) 1b1dem, p. 153 . 
heurlistics and innovation policles of leading compantes the wore a technological paradigm is 'driven" by the search strategles and objectlves of these compantes.

In order to understand general trends and major 1 ssues in process control one can make a flrst attempt by analyzing technologleal paradigms in process technologies and information technology which have become interlocked in process control. Process technologles to be looked at are iron and steel processing, food processing and the most important example of process technology, chemical processing. A11 these technologies are major fields of application of control technology, although the impact of control technology differs for each process technology. Nevertheless changes in control technology have to be seen against the background of changes in these fields of technology at the "demand side".

Chemical processing can be considered a mature technologlcal paradigm since about 1960. Before 1960 both process and product innovation were generated but in retrospect it 1 s remarkable how many product Innovations were established in the first half of this century. Since the sixties only few product Innovations have come about and, with the exception of the wider application of new materials; most innovations to date are process 1nnovations. In the present state-of-the-art generlc tasks in chemical processing. deal with further improvements of catalysts and chemical reactor design, the development of new separation techniques, energy saving and reduction of emisstons. All of which is coupled with 1 mproved and more sophlsticated systems of process control. A change of paradigm can be found in the large-scale introduction of blotechnology and a divertion of feedstocks. Changes in relative prices could stimulate further development and diffision of such technologles. However, both are not expected to have such a fundamental Impact at least unt 11 the next century.

It Is Important to note that technological development in chemfical processing has influenced industrial production to an extent which goes beyond the chemical sector 1tself. Developments with in the existing paradigm in chemlcal processing have not only affected process control, for which it can be seen as a 'nursery' of many of its applications, but it also finfluenced Industrial procesaing in other sectors, e.g. In food processing and the plastlcs industry. 
Food processing has gradually changed from a traditional technique as a craft to one of Industrial processing. In that process of change food processing first went through a phase of mechanization followed by automation. In this development toward Industrial processing it was necessary to achlewe more scientific and technologleal underatanding of basic processes. As this understanding 1s at1l1 underdeveloped, food processing can only be seen a a less developed technological parad1gm in which handicraft is stll1 relevant to many bub-disciplines.

Many technological routines and new processes have been taken from other process technologies. In particular chemical and plastics processing have set examples for separation, extrusion and other techniques which are frequently applied in food processing.

Modern foodprocessing is st 111 faced with various problems related to changing from batch to continuous processing. Technological barrlers st111 to be overcome are due to a lack of process knowledge, the 1nhomogenelty of feedstocks, problems due to control of a large number of process vartables and the absence of a wide range of sensors for organoleptical properties. Process control plays a role in the search for advanced processing, not only in the application of computer control but also in the introduction of automatic optical systems, quality control, a wide range of sensors and automation of welghing and packaging.

At the horizon of technological possibilities biotechnology can be been as a future, new paradigm in food processing. So far blochemical processing has had little cost advantages. Soclal and economic acceptance, therefore, is not an ssue yet and my cechnological problens st11 have to be solved.

A third Held of process technology which ls relevant to understanding changes 1 proces control 18 found in 1 in and steel processing. The present paradigu can be seen as mature fleld of techology which has materlallzed in incremental changes within the existung 1ntegrated coke-oven, blast furnace, oxygen steel waking process. Since the severtles the search for further process Innovations has been directed towards:

- efficlency of production routing: 
- energy saving (energy costs count for about $25 \%$ of production costs);

- Improvement of product yleld and quality.

In Iron making technology economies of scale have reached their theoretical upper 11 mit. Search for further enhancement is concentrated on energy conservation, sultabllity of so far unapplied sorts of coal and process improvements in control of charges, blasting procedures and temperature.

Moder steel processing ts based upon oxygen steel maklng and contimuous casting which were both developed in the early fifties, Further refinement of this process is found in the improvement of blowing technology, energy conservation, and more effictent control of casting. A1so in the downstream production of (semi-) fintshed products a search for improvement has been directed towards continuous processing and autonatic control. Compared to chemlcal and food processing, modern fron and steel processing is more advanced in overall production control with management Information systems.

As mentioned above the present dominant paradigw is found in the coke-oven, blast furnace, oxygen steel processing technology. An alernative paradig setting new rules for production technology can be found In direct reduction in tron waking technology and the wder diffusion of electric furnaces for steel making. Both technologies have passed their phase of experimentation, in particular electric furnaces are already applied in many "mint mills" and its history goes back to the beglining of this century. So far the Impact of these technologles have been, although by no means neg $11 \mathrm{~g} 1 \mathrm{ble}$, st111 too moderate to replace the exlsting paradignat a large scale.

For a further understanding of technological change in process control it ts necessary to pay some attention to developments in Information technology which 18 beyond doubt the most pervasive technological paradigm at present. Information technology. rellatively "young" fleld of technology, is concerned with information processing which is medlated through electronics and computers, software, and telecommunfation. Baslc trends, or general 
crajectories, fre found in continuing miniaturization, tmcreasing opeed of data procesising, Increasing rellabllity, and, although wth few exceptions, decreasing costs.

The first lectronle computers were introduced shortly after the second world war. Their main information processing technology was based upon triode-circuits. Although promising the first computers had some serlous drawbacks, they were expensive, "bulky', not very reltable and afficult to operate. In the later part of the fiftles transistors replaced the ald triode-circuits and computers became faster but many of the existing shortcomings continued. Since the early sixtles the search was directed cowards further minfaturization which was made possible through the introduction of hybrld circults. Major steps forward were made with the perfection of s1licon technology in micro-processors in the seventies.

In computer technology all this led to a wide range of applications and a varlety of types of computers some of which were designed in particular for process control.

In computer software major developments have been realized in the past decades as well. With the first computers programing was done by means of complicated procedures using e.g. the well-known punch-cards. Since the early fifties programming became somewhat less complicated with the Introduction of alphanumerlc codes. The search continued for a further development in "languages' for computer programing resulting in a succession of well-known computer languages such as Fortran, $\mathrm{COBOL}$, Basic, et cetera.

Since 1970 prices of computers have decreased substantially due to some of the maln trends mentioned above. Technological development In software resulted In a continulng price-decrease for so-called standardized software but an increase in prices for 'tallor-made' aophlaticated software. Present software technology is set for a move Into so-called artificlal intelligence, the translation of characterfstics of human intelligence into computer sysitems. A less far-fetched attempt to develop artificlal intelligence is found In expert systems.

The third element of information technology ts the improved telecommuntcations technology, of which swtching equipment, cranswission systems and terminals are most relevant. It was not unt 1 
the mid-sixtles that older electromechanical swltching equipment was replaced by electronic components although representation of sfgnals as st11 analogues. The digitaltzation and change to fully electronlc switching systems in the early seventies enabled the integration of computer and telecommulcations technologies. Transmission systems were flrst based upon copper cable technology and micro-waves. The latter system has been upgraded by satellite communication systems, the first is being replaced by optical flbres. Terminals for computer-comunication were introduced with the teletypewriter in the sixties. Since the seventies there has been considerable growth in so-called 'Intelligent' equipment which is much better sufted for sophistlicated communcation.

Al1 these changes and searches for more 'intel11gent' Information technology, no matter how relevant in their own right, st111 have to be "linked" to process control technology. In the following it w11 be demonstrated how some fundamental changes in process control led to a new paradigm which is heav1ly based upon the diffusion of Information technology. Here it will ouffice to note that computer technology has enabled more advanced and further reaching process control. Software is relevant not only for direct process control but also for upgrading of control into overall production contral for which telecommunication is essential to plant-comunication and intra-firm management information systems.

In the past hundred years process control developed from a very simple technology to sophisticated systems of contral at all levelo of production. In this development there is olear shlft of paradigm with the Introduction of computer control. The older paradigt, dated before the introduction of computers, evolved from very simple local manul control at the end of the 19 th century. In those early years there was 11 tt le to no welentific understanding of process behavlour. Few process varlables had to be controlled by the operator who made adjustments having read some Instruments. Gradually process control becme more complex and more automatic. Mechanical (pneumatic) devices, electrical Instruments and controllers, and the first analogous controllers 
were Introduced. In the perfod between 1930 and 1960 the expansion of the chemlcal Industry and chemlcal processing was parallelled by an upgrading of process control. There was an increase in the number of measurement variables with a simultaneous introduction of analogous, electrontc controllers at a large scale. It ts the perlod of central control where both operators and controllers become sltuated in the famllar central control room.

The Introduction of computerization of process control marks the shift towarde a new paradigm in control technology. This new paradigm with a greater Impact of Information processing on control is apparent in a change in the disciplinary matrix as well. From that period the industry is in need of technologists and engineers who are capable of lntegrating process and advanced control technologlies.

The period from 1960 to the mid seventles can be characterized as central computer control, 1.e. computer control from a central control robm. It lis a period of search for different options ranging from off-11ne control, to a variety of on-line and in-1ine options and so-called direct digital control. Desplte all efforts no option appeared unamblguously successful. Major problems were related to the rellability of existing malnframe computers and the costs of back-up fac1lities. A more well accepted solution was found in the introduction of a so-called 'distributed process control' which is dated from araund 1975. D1stributed process control meant a reversal of the trend of centralization in control with decentrallzed use of several computer functions. Developments in Information technology such as the Intraduction of microprocessors, the differentlation of computers into malnframes, mind"s and micro's and computer-like controllers such as PLC's, and adequate software enabled sophistlcated systems approach to process control. Computertized control was now made posstble at 1ocal, semi-local and centra1-control level.

Since the mid-elghties, search within the present paradigm is directed towards aystems with integrated control in which there is overall production control. In Integrated control the plant level 
Is overarched into control of all aspects of production such as processing, routing, avallability of raw matertals, flnanctal aspects and markets.

In the above changes, focal points, search and interrelations between several technologlcal paradigms have been analyzed. Overviews of such developments are presented In figure 4.1 and 4.2. Although linkages between different paradigms have not been drawn in the first picture it is easily recognized how different paradigms are connected.

Sophisticated computerized control and communication have been made made possible by technological imnovations in information technology. Modern industrial processing, e.g. In chemicals and steel processing, characterized by advanced control and a large number of process innovations has been aided by technical inputs from process control. Industrial processing in food technology is of a later date and Influenced by other process Industrles.

In figure $4.21 \mathrm{t}$ is shown how different stages of process control. have been influenced by information technology. The new paradigm starting with central computer control and also succeeding stages could not have been developed without advanced information technology.

Bas1c designs and key-elements_in_process control technology

Other relevant concepts for the study of technologlcal development at a lower level of abstraction than paradigm ere technologlcal. regime and bastc deston. Neloon and Winter introduced the concept of technological regime which they compared with the concept of a meta-production function. Thl meta-production function, a concept first Introduced by Hayam1 and Ruttan, has been described by Rosenberg as "... an envelope curve that goes beyond the production possibilities attalnable with existing knowledge and described In a neo-classlcal long-run envelope curve. It describes, rather, a locus of production posstbility points that can be discovered within the existing state of sclentific knowledge. Points 


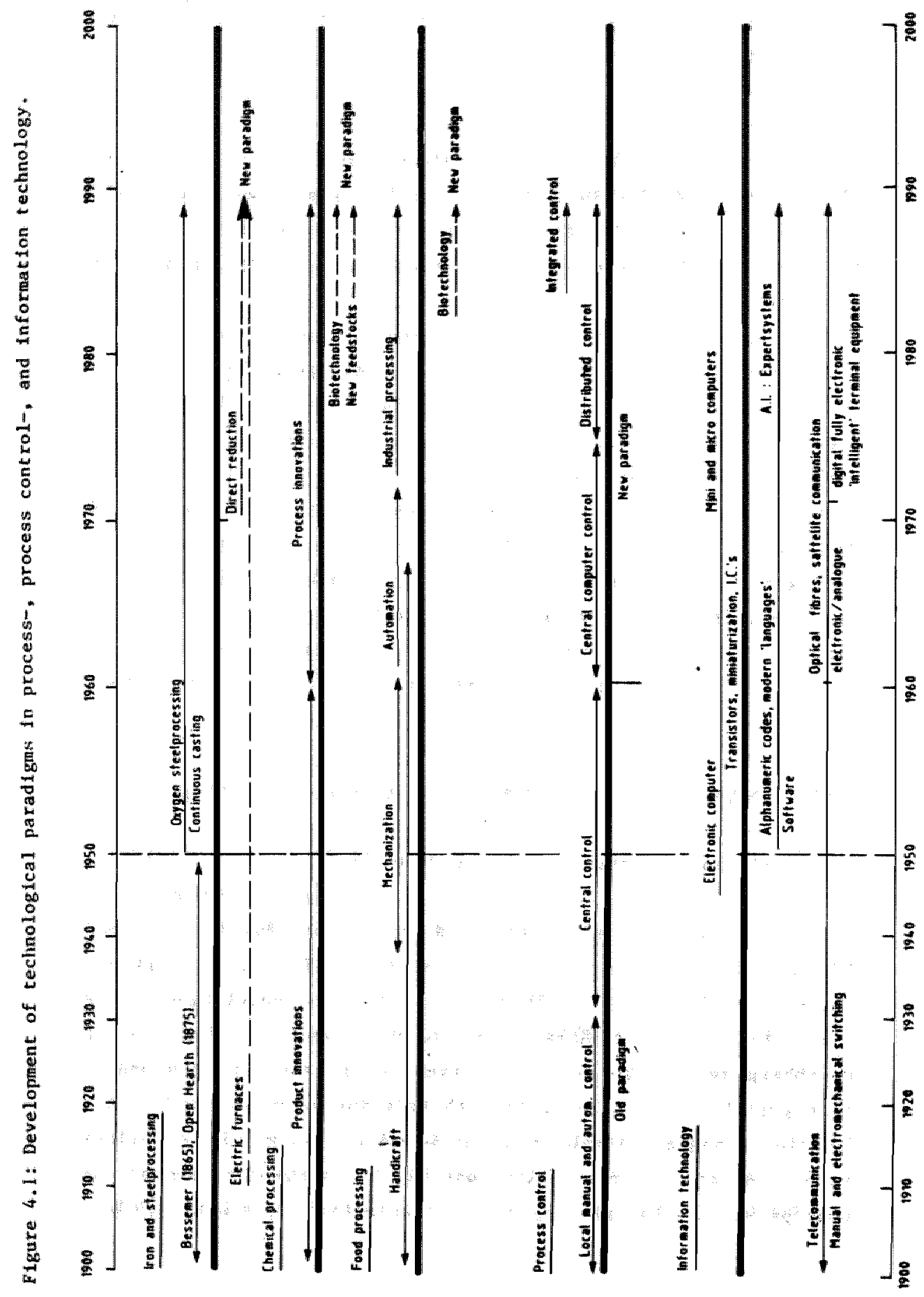




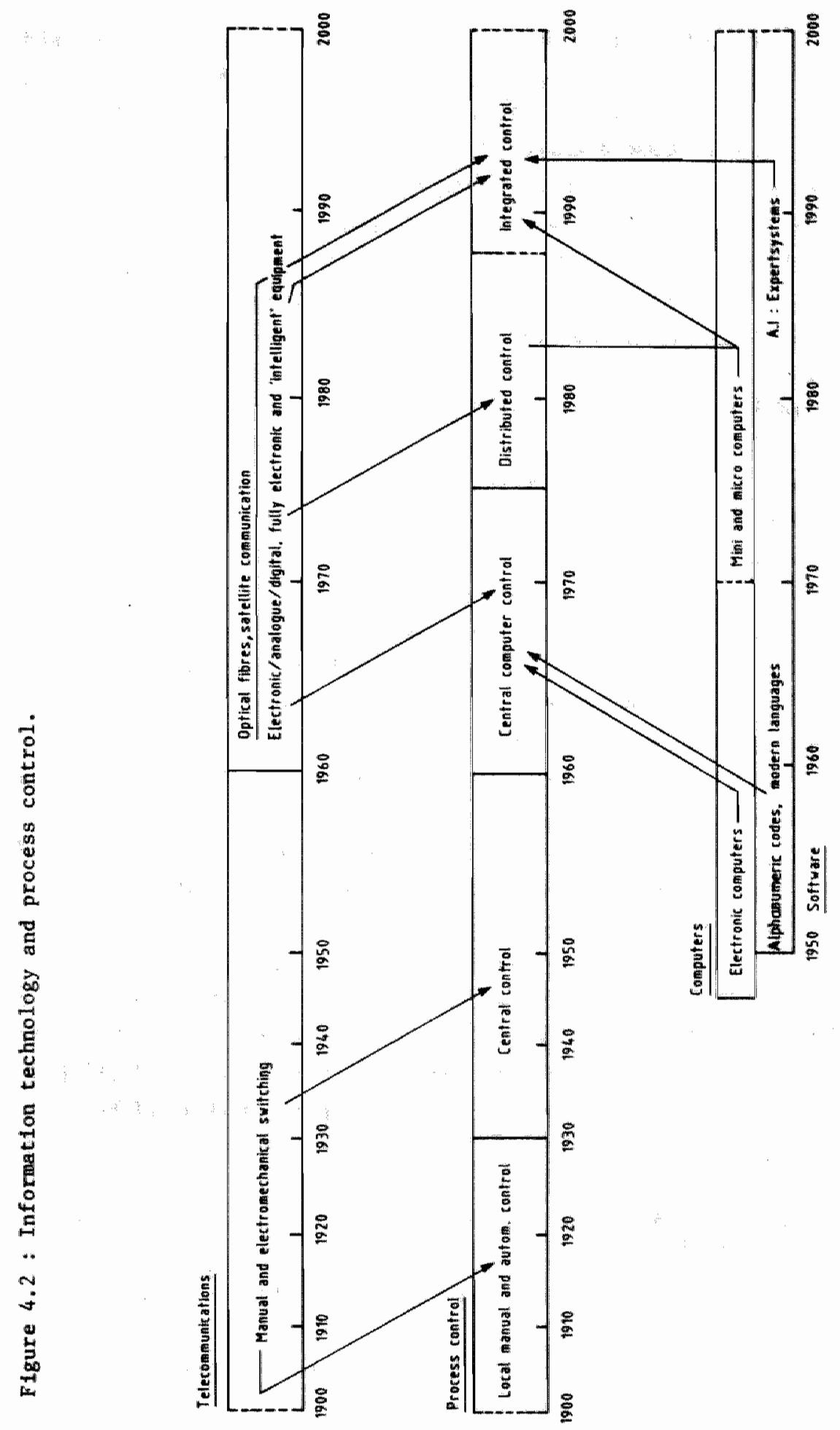


on th1s surface are attainable, but only at cost in time and resources. They are not avallable in bilue print form"1). This meta-production function has some resemblance to Schumpeter's previously discussed attempts to define imovation in terms of production functions. Nelson and Winter paraphrased this concept of meta-production function as" ... a frontier of achlevable capabilitles, defined in the relevant economic dimenslons, linited by physical, blologlcal and other constraints, glven a broadly deflned way of dolng things ${ }^{2}$. The concept of technological regime, however, 18 ".... more cogntt1ve, relating to techniclans" beliefs about what is feasible or at least worth at tempting" ${ }^{3)}$. An example of a technological regime, presented by Nelson and Winter, 1 s the development of the DC 3 and the cholce of materials, conatructions, engines; et cetera involved. The englneers working on the development of this afrplane had strong notions on the development of this reglme. In that sense Nelson and Winter's description of technological regime comes very close to one of Schumpeter"s attempt to define production functions as given technologlcal possibilities within the horizon of producers.

The concept of technological regime is also comparable to the concept of technological guldeposts introduced by Sahal. In his terminology a technological guidepost is a basic design which remains ".... unchanged in its essentlal aspects over extended periods of time" ${ }^{4)}$. A technological guldepost or baslc design can be seen as a more concrete model for further development with clear 'puzzle-solutions' as in Kuhn's 'examplars' of scientific development ${ }^{5}$ ). In the 11 terature the relation between 'regime' and "paradigm" is interpreted differently by some authors. To avold confusion I w11 interpret technologlcal reglmes as baslc designs. In my opinion, the interpretation of a regime in terms of babic

1) N. Rosenberg, Inside the black box: technology and economics, $1982, P, 17$.

2) R.R. Nelion and S.G. Winter, In search of useful theory of Innovation, in: Research Polley, Vol. 6, 1977, p. 57.

3) Ibidem.

4) D. Saha1, 1981, p. 33 .

5) See T.S. Kuhn, $1974(1962)$, p. 178 and 1dem, 1977, p. 298, and G. Gutting, 1984 . 
basic designs caw leat towards a wore concrete understanding of this concept. Compared to a technologlcal paradigm a baste design can be seen as material "precipltate" from one or wore paradigms. In the history of technological development there are numerous examples of basle designs apart from the already mentoned DC 3. The famous BDVAC, electronle computer, the flust Mcto-processor, the blast furnace in 1ron and ateel processing are all examples of bastc deslgas.

In a sense the cholce of a bastc design is given by the level of generality one is to choose. In the case of process control bastic deslgns can be understood as the configuration of the system of control. In the modern paradign of process control there are two baste designs:

- central conputer control with its conflguration of a malnframe computer 'Inked" to controllers, Instruments and sensors;

- distributed control with a variety of micro-computers which act as controllere; and

- a more extended version of the latter in Integrated control in which distruted control lis integrated Into an overall bystem of complete production control rangling from processe to management information and company strategles in wider context

For more concrete understanding of technologlcal development and the position of different companies which supply systems and/or distinct elements of aystems the description of complete syatens w11 not suffice. A further understanding of technological development might have to incorporate major components or products. Then a basic design or technologleal reglme should be further disaggregated into key-elements. A key-element can be defined a an essentlal component of a basic design. The cholce of essential components 1 based upon technical information.

In the study of process control it 1 s posslble to distingulah keyelements at different levels of control. From the lowest level of control upwards the following key-elements are to be mentloned: sensors, controllers, programable controllers, complete process control systems and production control systems, emphasizing software and system configuration. 
Sensors are devices which provide representation of condition varlables such as pressure, temperature, chemical concentration, flow, level, welght, et cetera. Sensors are closest to Industrial processes giving the inflal input of information to control systems. As there are so may different types of sensors it is difficult to relate technologlcal development to a few trends. In a very crude generalization it could be stated that the introduction and Integration of microelectronics in so-called "smart sensors" 1 a major toplc in sensor technology.

Controllers are information processing mechanisms which recelve data from sensors and which control the actual process, if mecessary new values for control varlables are calculated and this new information is sent to one or more mechanisms controling input varlables, e.g. shutters, valves and electromotors. Hardwired controllers were developed before World war II. The first generation was a pneumatic version, later generations became electronic controllers. At present hardwired controllers are considered as an absolete technology for most applications, usually applied in older Installations, or in pilot-plants and start-up situations. A modern version of the hardwired controller has become programmable, it is the so-called dedicated controller based upon dig tal programing techniques.

Programable controllers and programmable logic controllers are electrontc controllers which recelve their input from sensors. PLC' are frequently applied in security systems, in start-up and shut-down stages and in batch processing. Although the first PLC's were quite different from computers in terms of programing, dataprocessing, and storage of information, later sophisticated generations resemble process computers in many functions (see also tab1e 4.1).

With process control systems one reaches the higher hierarchical levels of process control. Although hardware ls still important with respect to the performance of malnframe-, min1- and microcomputers, systems archltecture and software aspects have become more relevant for underatanding technological development in process control. Wyth modern process control systems 1 t 18 possible to control processes from the actual processing upto the co-ord1nation of different stages of production. 
Production control systems with integrated control couple process control wh management Information systems. Information on processing can be conmected to other sources of information such as stock control, order processimg, logistics, planning, security control, quality control, malntenance, equipment monttoring, external information, commulcation wth other plants, et cetera. Production control systems wth integrated control is the most advanced stage of control, but few companies apply such aystems completely*

\section{Technologlcal_trajectories_and_generations in key-elements of process control}

So far most attention has been paid to the possibllity of analyzing technological development in terms of paradigms, basic designs and key-elements. In other words analyses at different levels of abstraction and generality. In some of the contributions mentioned in the previous sections technological development is analyzed in terms of trajectories. Dosi introduced the concept of techinological trafectory which resembles the concept of natural trajectory as put forward by Nelson and Winter. The latter 1llustrated their thoughts referring to Rosenberg's concept of technological Imperatives. According to Rosenberg technological imperatives guide the evolution of certain technologies, but Nelson and Winter lay more emphasis than Rosenberg on the 'straighter' path followed by natural trajectories ${ }^{1)}$. Nelson and winter do not pay much attention to the question of changes in natural trajectories. They more or less essume that:

a) there is a tendency for returns to fall if the prevalling trajectory is followed; and

b) occasionally knowledge is created which Improves the otructure of knowledge on technologies wh1ch had been 1 gnored hitherto.

1) Like Nelson and Winter Rosenberg stresses the cumulative and self-generating aspects of technology which make 1 th development proceed in particular directions, see $N$. Rosenberg, 1976 , pp. 110,111 . 
Then if this knowledge or these new technologles turns out to be effective, a significant shift in the nature of RQD is to be expected. This change might lnwolve not only wew knowledge but also different people and different firms. This new trajectory would be developed unt 11 the new areas of research become well explored as wel1 $1^{1)}$.

Dos1's concept of technological trajectorles is very close to Nelson and Winter" concept of natural trajectories. Technological trajectorles are defined by Dosi as patterns "... of "normal" problem solving activity (1.e. of 'progress') on the ground of a technological paradigm" 2 . From a purely terminological point of view I prefer this term technologlcal to natural because the latter might imply a somewhat deterministic connotation. In Dosi's perception technological trajectorles develop within a technologleal paradigm up to the boundaries of this particular paradign. These boundartes or limits of technological trajectorles are, in theory, defined in last instance by physical laws ${ }^{3}$ ).

In theorizing about technological development in terms of trajectories one touches upon the, already brlefly memorized, 1ssue of the possible deterministic character of such a notion if the social context of technological development is neglected ${ }^{4}$. Then, technological trajectorles follow a given path from which future results are determined by a narrow set of technical data. In my perception of technological trajectories there are both determin1st1c and voluntaristic elements in technological change. First of all, technological paradigm are made up of a broad set of search

1) The passage to which I refer did not occur in the text in Research Policy. It 1 s not clear whether Nelson and Winter themselves do interpret changes in technologies as explatned in the above as a bift of trafectorles. The context of this part of thefr text, however, suggest my interpretation. See R.R. Nelson and S.G. Winter, An evolutionary theory of economic change, 1982 , p. 262 .

2) G. Dost, 1982, P. 152.

3) See G, Dos1, Technolog1cal paradigms and technological trafectorles, in: C. Freeman (ed.), Long waves in the world economy, 1983, p. 96 .

4) See e.g. R.A. Walker, Technological deterwination and determinism: Industrial growth and location, in: M. Castells (ed.), 1985, p. 236 and $H$. van den Belt and A. RIP, 1987. 
procedures which are well accepted by a technological comunity. Such searching w11 result in basic designs which set the technological standards for a considerable period of time. The diffusion of such regimes is mediated by soclal acceptance. In capltalist economies companles, markets and soclal relations play a considerable role in this acceptance as they act as a selection environment ${ }^{1)}$. Depending on the character of a technology and 1 ts socioeconomic environment different soclal groups play different roles In the further development of paradigms and bastc designs. E.g. nuclear energy is to be seen as a particular technological paradigm which is influenced by a wider context of political and social groups and not just producers and procurers of nuclear plants. For other ffelds of technology, such as process control, the selection environment is usually restricted to suppliers and compantes which invest in the application of the technology.

If a particular field of technology is characterized by an "immature" paradigm it can be expected that several versions of bastc designs are to be found. In case of technological maturity or the dominance of one or a few suppliers it is to be expected that only one or a small number of basic destgns will feature. If one partlcular basfc design has become well accepted and dominant there w111 be technological improvements given the possibilities of that deslgn and technological trajectories follow a deterministic path. However this does not imply that all technological development is of a deterministic character as the improvements of basic design take place in an environment in which complex interrelations between changes in paradigms and economic selection set the wider context for technological development. In other words, as e.g. also polnted out by Plore and Sabel, technological development Is characterized by both diverglfication or patterns of "branching' and longer perlods of unfformity ${ }^{2)}$. A bastc design might be accepted for a period of time but 1 t can be made redundant by new technological options and/or falling acceptance by dewand. To give an example from process control technology:

1) See G. Dos1, 1982, P. 155, R.R. Nelson and S.G. Winter, 1977, p. 63 , and N. Clark and C. Juma, 1987, p. 40.

2) See M.J. Plore and C.F. Sabel, The second Industrlal divide posstbilities for prosperity, 1984, p. 39. 
In the early stxtles computer control was introduced to process control. A large malnframe computer "guided' processes from a centralized position. Th1 basic design of central computer control developed from so-called off-line computer control to direct 1gital control. Several technological trajectories have marked this "perfection" of this basic design. Once the computer was introduced 1ts role became more and wore cruclal. At first it was applied in an off-1Ine mode in whych the operator st 111 functloned as a $11 \mathrm{nk}$ between the actual controllers and the computer whlch was engaged in data collection and calculating of set-points, et cetera. At the next stage, the on-11ne mode, there is direct link between controllers and the computer, but computer "response" goes via the operator. In the In-line mode there is direct communfcation between controllers and the mainframe computer, the operator is st11l active in supervising process control. At the final stage of this trajectory all controllerfunctlons have been taken over by the central computer.

Once the computer was introduced as a central regulatory device the development towards in-1ine control and the change from analogue to digitalized systems became almost determined by the existing possibllities. However, this basic design of central control did not become well accepted and in the mld-seventies it was replaced by distributed control in which there is a multiple set of micro-computers. There are two reasons why central computer control was eventually replaced. First, user-companies were reluctant to accept the development towards direct control. Most compantes did not regard the system as very safe because all control functions were regulated by one computer. In case of fallure the costs of system breakdown would be enormous. An alternative could be found in extenslve back-up facllitles but thls turned the system Into a very expensive, complex, and therefore not a very popular control system.

The second reason for the change to another basic design is found In new technological options. Developments in information technology, the introduction of micro-computers and 'intelligent' controllers enabled the introduction of another system in which 
computer control could be performed at a decentrallzed level. This new system was less complex and less vulnerable than the previous basic design and it became the new basic design within few years time.

For further empirical research 1 will be necessary to operationaIlze technological trajectory in such a way that 1 ts cumularive and progressive character becomes clear. Sometimes it will be possible to 'measure" a technological trajectory wth a particular characteristic. E.g. minlaturization of micro-electronic chips with the number of components per chlp or the reliability of chlps with the relative rate of fallure per gate. For products for which quantitative information is less feasible a trajectory can be interpreted as a succession of generations of a basic destign or a key-element. Such a succession of generations is found in the trajectory from older (obsolete) generations, to average practice, best practice, technologlcal frontler and/or sclentific frontier. The older (obsolete) generation of a baslc deslgn (or key-element) can st111 be in use but it w11 only be supplied for repllacement purposes. The average practice generation is the ordinary standard and usually modal application and a best practice generation represients the most advanced level of technology which 18 applied commerclally. The technological frontier refers to applied research and In particular development of the near-future generation. The scientific frontier will be found at the most advanced level of basic research which is not directly almed at nearby future results. The gap between technological and selentif $1 c$ frontier will probably be most unclear in so-called science-based industrles, where both technological and sclentiflc knowledge are to a large extent regenerated whin the industry 1tself. It will be evident that the description of generations 1 an ex-post generalization and subsequent basic deslgns will each show several generations for which the time-horlzon will vary.

The generations or technological trajectortes for each key-element in process control are shown in table 4.1 . 


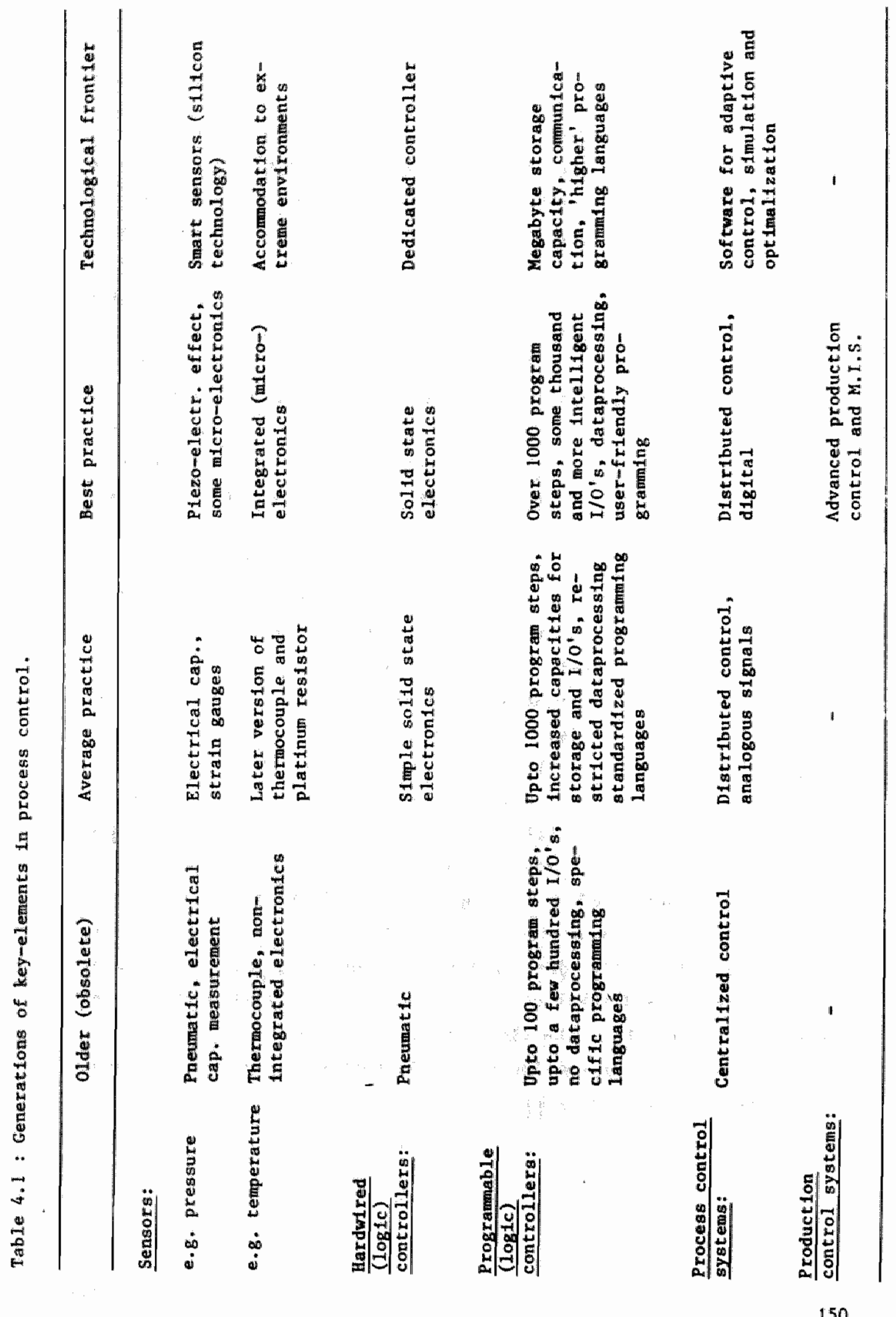


A theoretical framework which applies rather abstract concepts such as technological paradigms, trajectories and bastc designs is extremely useful for 'painting with a rough brush', but it is less attractive for incorporating it into a more standardized method of economic analysis at a lower level of aggregation. The only way to improve the usefulness of such a framework 1 s to find more operational defintions and constructs for some of these concepts in order to measure technological development. A stimulating contribution to this field of Innovation theory, has been made by Metcalfe and Saviottil ${ }^{1)}$. They provide a construct for analyzing and measuring technological change in a detalled description. This approach resembles Knight's contrtbution of functlonal and structural measurement of technology. Rnight proposed an analysis of the evolution of technology based on functional and structural descriptions of a technological system, or a basic design or keyelement in the present terminology. Structural descriptions are restricted to key information related to basic operations, omitting unimportant features. Functional descriptions are obtained by describing a vector of performance capabilities ${ }^{2)}$.

Saviott and Metcalfe percelve technological development in terms of changes in technical and service characteristics of products or processes and by a change in the pattern of mapping these characteristics. The relation between both technical and service characteristics is shown in figure 4.3 below.

1) See P.P. Sav1ott1 and J.S. Metcalfe, A theoret1cal approach to the construction of technological output indicators, in: Research Pollcy, Vo1. 13, 1984, see also P.P. Savlott1, P.C.

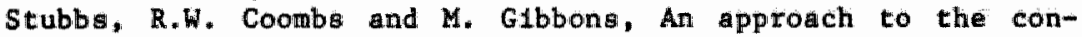
struction of indexes of technological changes and of technological sophistication, in: Technological Forecasting and Socfal Change, Vol. 21, 1982, and P.P. Saviott1, An epproach to the measurement of technology based on the hedonic price method and related methods, in: Technological Forecasting and Social Change, Vol. 27 , no. $2 / 3,1985$.

2) See K.E. Knight, A functional and structural measurement of technology, in: Technological Forecasting and Soclal Change, Vo1. 27 , no. $2 / 3,1985, \mathrm{pp}, 107-127$. 
Figure 4.3: Representation of a product as two sets of character1stics, technical and service, and a pattern of mapping.

Technical Service
characteristics characteristics

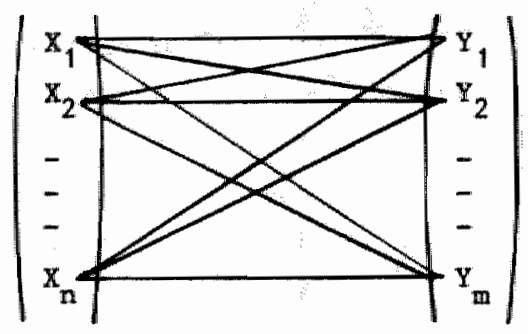

Pattern of mapping

Source: P.P. Saviotti and J.S. Metcalfe, 1984, P. 142.

Within this framework there are flve dimensions of technological change:

a. change in absolute values of $x_{1}$;

b. change in the mixture or balance of $x_{1}$ (changes in weights);

c. change in the pattern of mapping $\left(X_{1}\right) \leftrightarrow\left(X_{j}\right)$;

d. change in mixture or balance of $Y_{f}$;

e. change in absolute values of $Y_{j}$.

Elaborating upon this Savilott and Metcalfe applied both technological reglme and technological trajectories. They described a technological regime, or basic design, as "....consisting of a given liat of technological characteristica $x_{1} \ldots{ }^{1}$ ). A technological trajectory 1 is defined by them as the pattern of gradual Improvements of $x_{1}$.

Apart from technlcal and service characterlatics they distinguish process characteristics as wel1. Consequently "... any trajuctory will have joint Implications for the set of service characteristics and the set of process characteristics. If the set of $x_{1}$, is changed, we have a change of reglme and thus the definttion of a

1) P.P. Savlott1 and J.S. Metcalfe, 1984, p. 145. 
new technological trajectory"1). In theory the analysis can be extended to three different situations: a substitution of a regime, the appearance of a new product and partlal substitution. Such contributions to the theory of 'technometrics' have been subject to a lively debate in the world of technological forecasting and related flelds of interdisclplinary research of technological change. Measuring technological development in terms of character1stics. In particular if combined wh the so-called hedonic price method, is not free from some serlous questions about its usefulness. Without attempting to discuss all relevant issues in this fleld I w11 point at some of the most interesting items of the debate.

Lenz mentions three approaches in measuring technological development. (Lenz refers to a heuristic approach, but I think at this level of abstraction they apply to other approaches as well). These three approaches are:

- the single parameter approach, In whlch one particular parameter is defined to determine the operational superfority,

- the parameter tree approach which defines a hierarchy of parameters of which the values are traded-off in lawer branches but which culminate in one or a few primary measures of performance, - or, a single value measure as an all encompassing compound measure of performance ${ }^{2)}$.

The single parameter and ingle value measure can be chosen if there is consensus about the superiority of the chosen parameter or If there is a clear discriminating value. However, both provide so much more measurement than real understanding of different $1 \mathrm{n}$ fluences upon technologtical change. E.g. measuring productivity growth in value indicates technologlcal development, it does not provide is with Information about underly ing factars.

A parameter tree sort of approach can be the prellminary work in achleving vector of characteristics if a hlerarchy of parameters 1s applied to deduct a number of primary measures or characteristics.

1) 1 bidem.

2) See R.C. Lenz, A heuristic approach to technology measurement, In: Technological Forecasting and Soclal Change, Vol. 27, no. $2 / 3,1985, \mathrm{pp} .249,250$. 
In bullding a set of characteristics a number of constraints have to be considered. Apart frow the lack of relevant empirical information, which can be declsive, there are some theoretical shortcomings which have to be discussed first. A major obstacle in bu1lding a list of characteristics is found in the heterogeneous character of most products. In theory it is posstble to relate a number of heterogeneous products to basic design. The character1stics of this design can be gathered by using technical data references in comblnation wh consultance of technical experts, and principal components analysis. Alexander and Mitcheli mention three problems related to building a set of characteristics for heterogeneous products.

These methodological problems arise when:

- there is a change in relative importance of characteristics,

- new characteristics are added,

" others are eliminated ${ }^{1)}$.

Furthermore, in measuring technological development of a particular basic design or key-element one has to take into account the trade-off"s between several characteristics. Such considerations lead towards a 'moderate' view on the use of characteristics. Applying characteristics is by no means an objective method; if a considerable Input of technologlcal knowledge has been used it is posstble to reach a stage of 'convenient' inter-subjectivity. Longltudinal monitoring of bastc designs and ut1lizing the knowledge of a large number of experts can diminish the risks involved in the shortcomings as mentioned by Alexander and Mitchell.

In Hagedoorn et 1 . an attempt was made to 'measure' technological trajectorles $\mathbb{H n}$ so-called key-elements of process controllers, such as sensors, hardwlred controllers, programable logle controllers, process control systems and production contral systems ${ }^{2)}$. Technlcal and service characteristlcs which were analyzed sepurately In Metcalfe and Saviotti were jolned as service

1) See A.J. Alexander and B.M. MAtche11, Measuring technological change of heterogeneous products, in: Technological ForecastIng and Soctal Change, Vol, 27 , no. $2 / 3,1985$, p. 193.

2) See J. Hagedoorn, P. Kalff and J. Korpe1, 1988, pp.114-133. 
and technical characteristics appeared to be too interrelated to justify a distinction. The number of characterlstlcs per keyelement varied from 5 to 10 ; for each key-element the actual characteristics were deducted from the technical literature and checked with a large numer of experts.

An example of such 'measurement' is given in table 4.2 for technological trajectories in pressure-sensors.

For each characteristic of all key-elements the changes were 'measured' for three generations and the technological fronter was also Indfcated where possible. Unfortunately, quantiflable information could only be obtained for some characteristlcs but then again such quantifled measures do not share a common denominator. Therefore, development for each characteristic was given in a quality mark ranging from I (lowest quality) to 5 (highest). The markings were obtained by collecting all markings and technical elaborations provided by technical experts. Hence, such a measurement of technolog1cal development in terms of technological trajectorles is of a fairly 'Intersubjective' nature.

In the example in table $4.21 \mathrm{t}$ can be observed that there has been a clear improvement for most characteristlcs from generation to generation. An important field of future developments can be expected in the Improvement of the useful temperature range, a characterlstic on which best practice sensors fall to score more than satisfactory due to the present Iimltation in silicon technology. Through the analysis of a number of key-elements it 1 posstble to achleve a falrly thorough, albelt qualitative, understanding of many aspects of technological trajectories in a particular fleld of technology.

\section{Technolog Lca1 development gs an evolut lonary_process}

In the above I have made an attempt to re-organlze conceptual framework for understanding technological development. This framework leads from a general level of analysis in terms of paradigms to technological trajectorles in terms of generations within key-element of a basic design. It enables the identification of major heuristics, be it at the level of a paradigm or a key-element. Rules of search, focal points in industrial R\&D, Incremental 


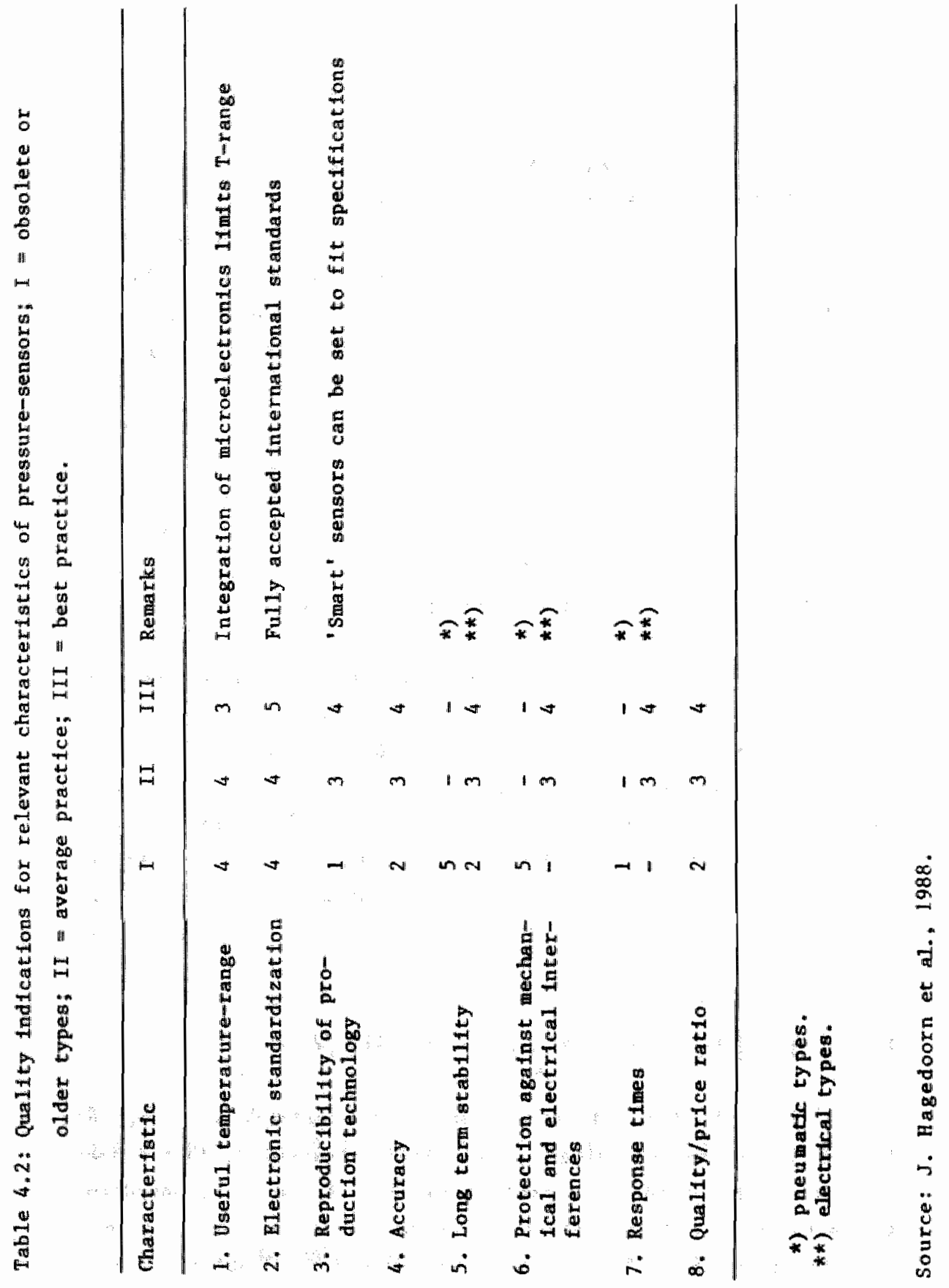


changes and more radical changes in technology can be 1 dentifled. As the analysis covers both general trends and speciflc developments, and system development and technological trajectorles in key-elements, It accomodates criticism on the shortcomings of an analysis based on 1solated subsystems as e.g. Hughes has formulated. The latter has critictzed those analyses in which 'technologlcal systems', basic deslgns in the present analysis, are divided Into "... subsystems and calling them systems for purposes of comprehensibllity and analysis (which) ... may offer only a partial, or even distorted, analysis of system behavior" "In the foregolng analysis of process control developments in both control systems and key-elements picture technological change of a system and its major components. Then if the analysis proceeds towards industrial economics it will enable a further analysis of diffusion of particular technologies and the industry structure of suppliers of both systems and components. It also supports the explanation of the history of technological development, the interrelatedness of different fields of technology which would otherwlse be reduced to 'pale' Indicators such as RaD expenditures or number of patents. This does not imply that quantitative ind1cators are to be seen as useless. Statistics provide very valuable Information even if, as in the case of technological development, the sheer number of indicators avallable is restricted. The interpretation of such statistics, however, w111 be improved considerably if they are placed against a background of a more than superficlal understanding of technology 1taelf. Then, changes In the speed of technological development, new areas of search, "cross-fertilization" of once separate technologies and succeeding perfods of radical and incremental change, which w11 all be extremely difficult to deduct from statistics, can be interpreted If the theoretical framework of an evolutionary underatanding of technological development is applied.

At the level of analysis of concrete key-element of a batic design it is possible to achleve some in depth understanding of actual technological trajectarfes for major characteriatics of

1) T.P. Hughes, The evolution of large technological systems, in: W.E. Bifker, T.P. Hughes and T.J. Plnch, 1987, P. 55. 
such key-lements. As demonstrated in the next section these insightit will turn out to be very useful when the analysis of technologlcal development in an industry is connected with the study of the diffusion of technology.

In the foregoling section the cumulative character of technological development stressed in explaining the viability and advantage of concepts auch as technological paradigms, baslc designs and technologlical trajectorles. These thoughts on technological traJectories and the 1 ike stress the gradual development and shifts of best practice technology and technological frontiers. In this section I wil relate the diffusion of technology to this evolutionary character of technological development.

Relating diffusion and technologlcal development might seem somewhat peculiar at first sight. After all, diffusion, defined as the progresslve distributional change in the spread of an Innovation or a technology, is understood to be at a different level of anflysts from technological development itself. In particular in neo-classical economics dffusion and Innovation have been separated as two distinct lesues ${ }^{1)}$. However in reality the process of diffustion of innovations or new technologies is not only characterlzed by a gradual growth of adoption it also has a cumulative character. In my opinion it is important to see diffusion and technologlcal advance in their interrelatedness. As e. 8 . explatned by David both technological development, In the sense of advancing frontiers and in particular the dffusion of technology have far-reachting consaquences for economic development ${ }^{2)}$.

1) See e.8. C.G. Thirtle and V.W. Ruttan, 1987, Pp. 130, 131.

2) See e.g. P. Davld, Technology diffusion, public pollcy, and industrlal competitiveness, In: $R$. Landau and $N$. Rosenberg (ed.). The positive sum strategy, Harnessing technology for econonic growth, $1986, \mathrm{p}, 376$. 
In the following I w11 first pay some attention to the theory of diffusion wh emphasis on those contributions which stress the cumulative character of diffusion. This enables me to connect diffusion with technological change in terms of trajectories and generations of key-elements of a bsic design. Following this procedure I 111 be able ta demonstrate the viabllity of such an approach with the analysis and measurement of diffusion of Information technology in process control equipment sector.

\section{Stylized patterns of diffusion}

Despite many differences in arthodox theorles of diffusion there is a "communis op1nio" among many students of diffusion about the pattern of diffusion processes. This pattern of diffusion follows Schumpeter's description of the process of innovation and imitation, the so-called bandwagon effect with a few originators and a slowly growing number of imltators or followers. This pattern of diffusion is generally pictured as a sigmold (S-shaped) curve. These $S$-shaped curves can be generated by different models, including logistlc function, Gompertz function, the modiffed exponential function, the cumulative normal distribution function and the cumulative log-normal distribution function, all of which are based on different assumptions of which it 1 , according to Sahal, "... not possible to discriminate (....) on empirical grounds"

Nabseth and Ray have 1isted six factors which might influence this sigmold curve in the opening phase:

1. At a first stage of risk and uncertainty just a few firms will try to be the first to innovate.

2. If few flrms succed they reduce the risk for others which have not yet adopted the new technique.

3. Information from users has a great influence on the large majority of firms (more than information in the press or from suppliers).

1) Sahal, 1981, p. 78, see also W. Mahajan and R.s. Peterson, Models for innovation diffusion, 1985, p. 10 . 
4. Modifications of Innovations increase both the potential range of production and the superforfty of new methods over the existing ones.

5. "..." there may be a bunching of the new adoptions as part of a cyclical mechan 1 sm of Schumpeterian type".

6. The age of the existing technology can be in favour of the new technology.

They also present two factors which can slow down the diffusion process, if:

7. there is a more or less restricted number of areas of application, or

8. the muccess of new techniques stimulates improvement of the first existing technique ${ }^{1)}$.

The material basis for this s-curved pattern of diffusion is of ten found in the growlng number of firms or units within firms which gradually learn to adopt new technologies. A large number of theories and models attempt to explain diffusion more specifical$1 y^{2}$. Some models take the concepts of Baysian learning and reduction of uncertainty as central elements, many others are related to Mansfield"s theory of both Inter- and intra-firm diffuston as an epidemic process.

Although S-shaped curves are in general accepted as a realistic approach to diffusion processes, there is evidence that some empirlcal findings and theoretical considerations do lead towards a more differentiated approach. In his study of six mature technologles Ray atresges the need for a cautious approach. In his find1ngs "... the figures do not provide much concrete evidence for the exclusive validity of any very regular s-curve but they defin1tely support the rational expectation of some kind of an s-curve (....). The slopes are different for each technology, the turning point into growth also differs and therefore the use of an s-curve

1) See L. Nabseth and G.F. Ray, The diffusion of new Industrial processes, $1974, \mathrm{p} .9$.

2) For reviews of many of these models, see C.G. Thirtile and V.W. Ruttan, 1987, P. Stoneman, The ecomomic analysis of technological change, 1983, Pp. 65-134, and L.A. Brown, Innovation diffuston, 1984 . 
assumption for various purposes, for example, forecasting, requires caution"1). A further crit1cism of the S-shaped conception of diffusion has been put forward by Gold ${ }^{2}$. Gold's alternative to the s-shaped diffusion curve seems to be falriy compatible with the evolutionary theory of technology outlined in the foregoing section. He critlcizes the present method of measuring diffuston because:

- "... counting the number of plants or firms using the Innovations obviously falls to indicate whether these represent only ifmited developmental applications or pervasive comitments".

- Measuring output of new technology is more effective, but even then $1 t$ is hard to determine "..... whether any given output represents high or low levels of diffusion of the particular innovation being studied" 3 ).

If output is considered as an indicator of diffusion it usually involves the assumption that a particular innovation is applicable in all of the production of that industry. This conception of diffuston is in fact a saturation model approach, in which "... It is supposed that a specific innovation is progressively adopted by an unchanging and essentially homogeneous population of potential users! ${ }^{4}$ ).

In a more dynamic approach ta diffusion both the population of potential users and the Innovation ttself will change during the process of diffusion. E.g. In the process control industry the diffusion of information technollogy has been influenced by the crass-entry of companies from the electronics industry which changed the number of potential users, see chapter 3.2. The changes within the cechnology 1 tiself can be explained as changes within technological trajectorles. If a particular Innovation, or

1) G.F. Ray, The diffusion of mature technologies, 1984, p. 80.

2) See B. Gold, Technological diffusion in Industry research needs shd shortcomings, In: Journal of Industrial Economics, Vo1.29, no. 3, 1981, and 1dem, on the adoption of technologlcal imnovations in industry: superficial models and complex dectsion processes, in: S. MacDonald, D. Md. Lamberton, T.O. Mandeville (ed.), The trouble with technology, 1983.

3) Gold, 1981, p. 249.

4) Gold, 1983, p. 105. 
In the present terminology a basic design or a key-element of it, goes through a process of diffusion the parameters can change frow generation to generation. If technological trajectories within a product are defined in terms of generations then the process of diffusion is not so much characterized by a single diffusion curve but instead by an envelope of successive curves or different stuations regarding diffusion ${ }^{1}$ ).

Such Ideas about technologlcal change and generations can be elaborated upon for some hypothetical sttuations as follows:

Technological development within a particular basic design or a key-element is to be seen as the gradual improvement of a basic deslgn along technological trajectories. Different stages of this Improvement are found in subsequent generations which can, in retrospect, be seen as older, average and best practice. The relation between technological development and diffusion is plctured in a stylized diagram in figure 4.4 , showing some basic 1deas about this matter.

If a flxed population of potential adopters is assumed, the diffustion of three generations, representing technological trafectorles, can follow a sigmold pattern. The particular shape of the diffusion curve is generated by the rate of diffusion of the three subsequent generations. Technology 1tself ts changing in terms of generations while the number of adopters grows over time as the technology is 1mproved. Gradually the diffusion of the older technology is declining but the other two generations more than compensate for this decline.

1) See also B. Gold, 1983, pp. 107, 108, J.S. Metcalfe, Impulse and diffusion in the otudy of technological change, in: Futures, Vol. 13, no. 5, 1981, and L. Soete and R. Turner, Technology diffusion and the rate of technical change, in: The Economic Journal, $94,1984, R$. Coombs, P. Sav1ott and V. Walsh, 1987, PP. 124-133, C. Freeman, Diffusion: The spread of new technology to f1ms, sectors and nations, 1987, and $V$. Mahajar and R.A. Peterson, 1985. 
Figure 4.4 : Diffusion of generations of a product within a fixed population of potential adopters.

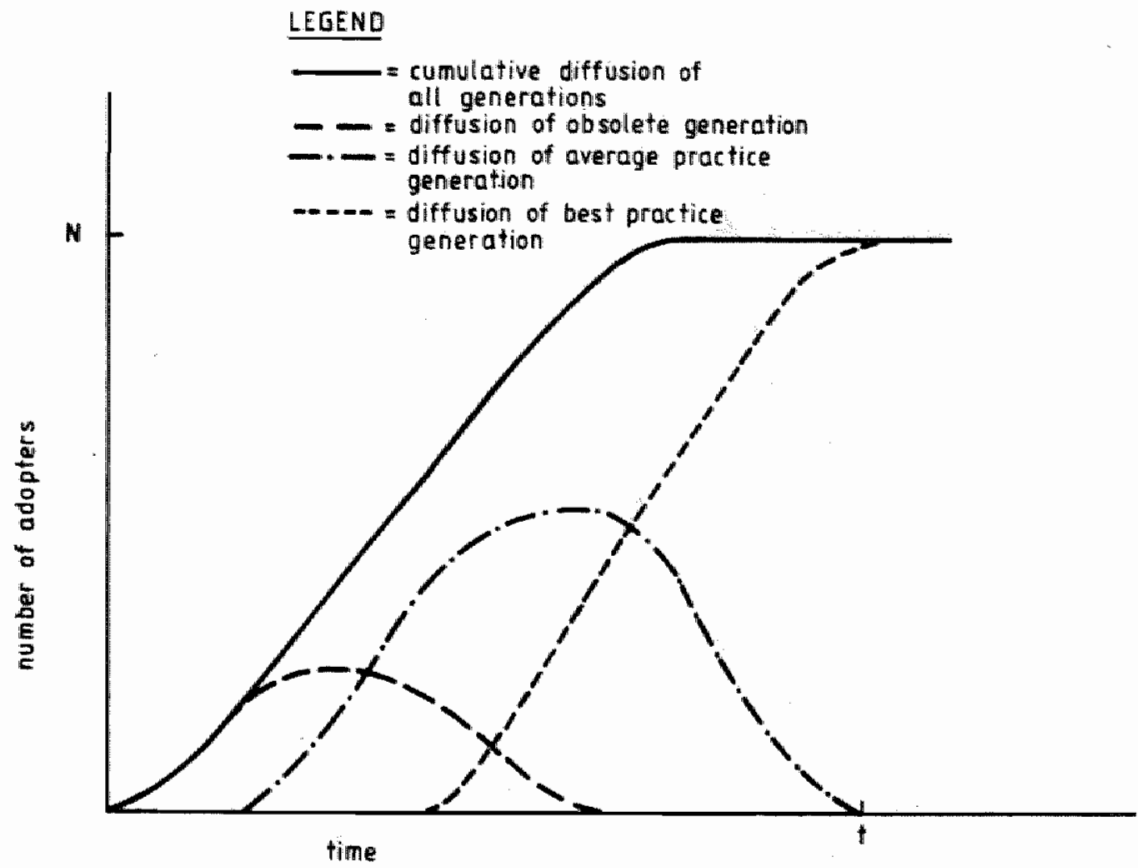

In figures 4.5.a and $b$ the relation between diffusion of gubsequent generations and the overall diffusion is platured for situation with rapid diffusion and another with slow diffusion. In case of rapld diffusion it is obvious that the subsequent generations will follow within due time. If diffusion evolves slowly, the overal1 s-curve is 'flattened' as the gradual diffusion of each generation takes more time than in the other situations pletured in figures 4.4 and $4.5 . a$.

These general ldeas about diffusion and generations will be applled in the analysis of diffuston of information technology in generations of key-elements of process control in a following paragraph. 
F1gure 4.5.a : Rapld diffusion of generations of a product with a flxed population of potential adopters.

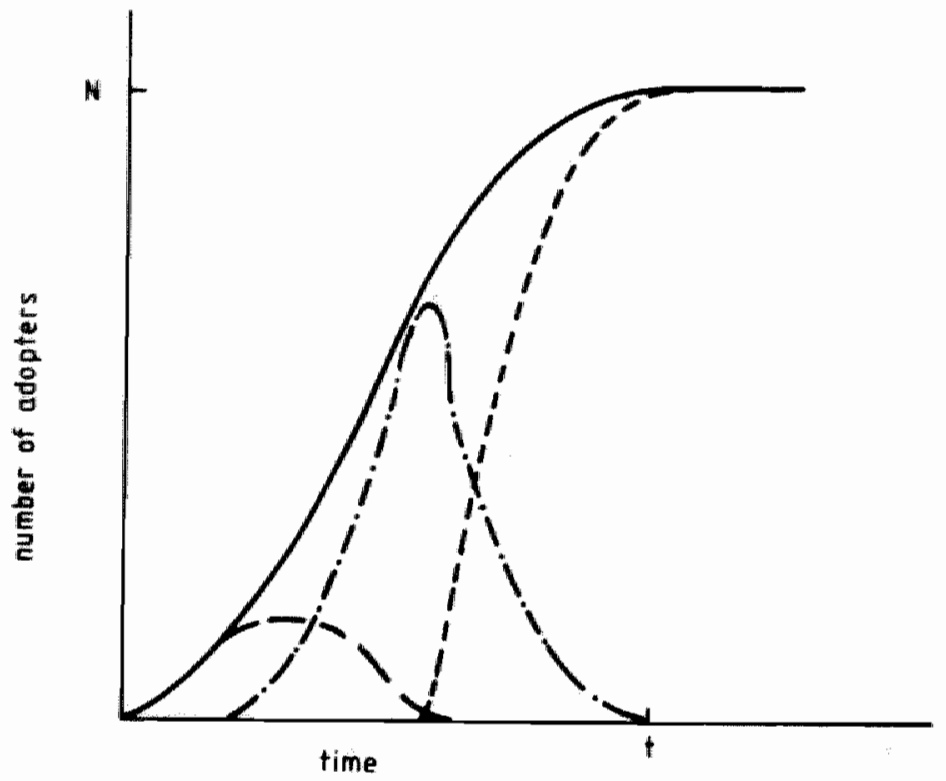

Legend: see figure 4.4 .

Figure 4.5.b : Slow diffusion of generkitons of a product within a fixed population of potential adopters.

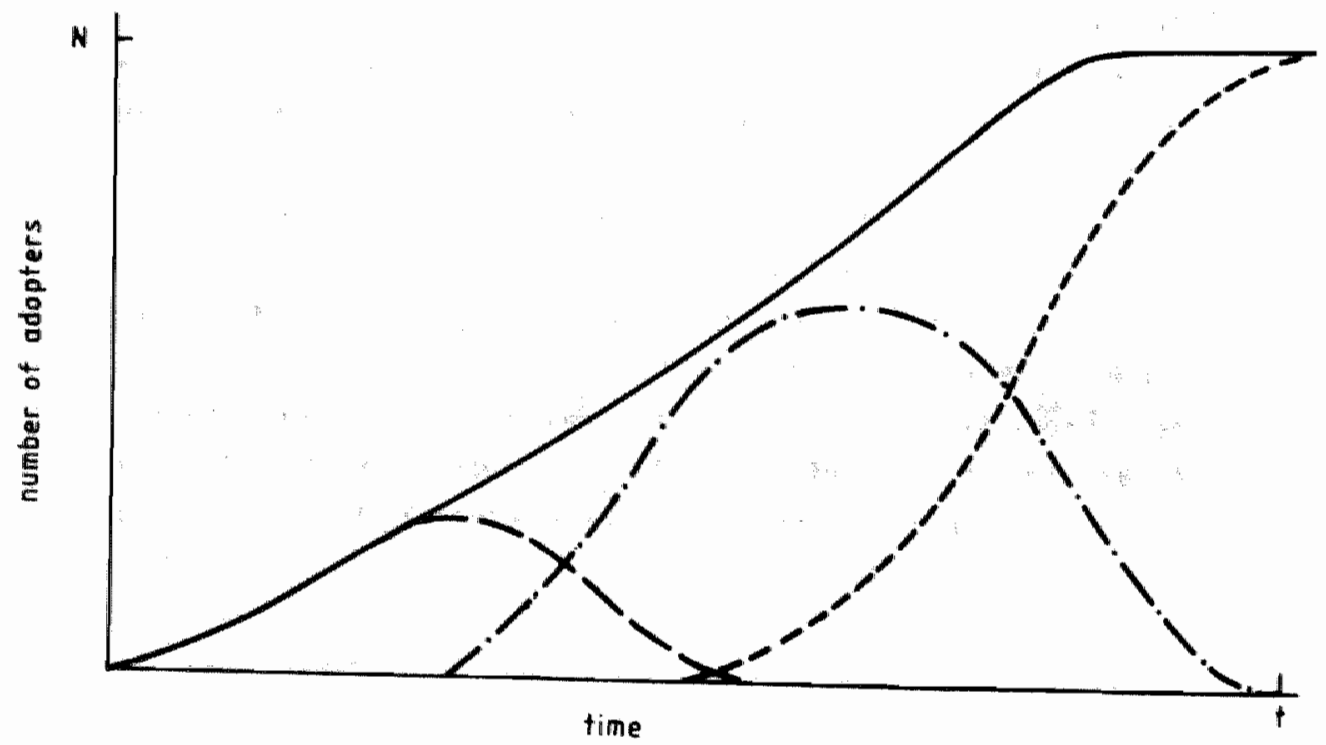

Legend: see figure 4.4 . 
So far economic theory has not been able to provide more or less general theory explaining the diffusion of technologfes. Some economists even doubt whether $1 t$ is at all possible to draw up a gemeral theory of diffusion. As Rosegger has stated "..." the diffusion of innovations is probably too complex a phenomenon to be explalned in general for all types of technology and all kinds of potential adopters, no matter how many factors one takes into account. Therefore, whlle a general theory about, say, the spread of epidemics may be very useful, we are not Ifkely to gain any great Insights from an all-encompassing theory of diffusion in the econonic setting". 1). Instead of a general theory Rosegger opts for a range of different hypotheses for different industries and innovations. Whether Rosegger is right in princlple or not, the present state of diffusion-research does suggest that a modest and 'mlddle-range theory' approach would be more fruttful in the present situation. A review of the relevant literature shows the relevance of this approach in wiew of the contradicting outcomes of many studies regarding different key-factors of diffuston. Key-factors which are frequently mentloned are:

- Profitability. If new technologies are more profitable than conventional technologies then one might expect a relation between expected profitability of an Innovation and the speed of diffusion. So far several studies by Mansfield, Duchesneau and Hakanson show a significant correlation, although others, e.g. Smith and Romeo, did not find a significant result ${ }^{2}$.

- Flnancla1 resources. Nabseth and Ray 11st access to capita1. together with overall profitab111ty and the ettitude of management as the three most important factors influencing diffusion ${ }^{3)}$. In most studies it is found that absolute capital requirements have some $\mathbb{1 n f l u e n c e}$ on diffurion.

1) G. Rosegger, The economics of production and Innovation, 1980, p. 246.

2) See J. Kle1ne, Investitlonsverhalten bel Prozessinnovationen, 1983, P. 107 and P. Stomeman, 1983, P. 90-94.

3) See L. Nabseth and G.F. Ray, 1974, P. 20. 
- Stze structure and organlisation. As Nabseth and Ray stated: "... Large companies may, for a number of economic, technologlcal, or other reasons, behave differently from medium-sized or mall ftrms: the organisation and structure of the industry as well as of the companies $(\ldots .$.$) can also have a marked$ effect on diffuston, and may be particularly tmportant in explainfing International differences. High concentration, or a monopoly position, way create conditions which can influence Innovation or diffuston elther way." 1 ).

In general, size of flrms is introduced as an explaining variable In emplrical studies because, from a theoretical point of view, Mansfield"s position 1 s supported where it is argued that large firms are better able of diffusing innovations due to their finarial resources, capacity to manage information and to maintaln large RGD facilities. However, even here we find rather contradicting results. In a study covering ten processes Nabseth and Ray find $" . . .$. no definite evidence that large companies have always been in the forefront of technical progress in the gense of being leaders in innovation and the adoption of new techniques". 2) . In a more recent study Ray concludes that ".... slze has less to do with the diffusion of new technologies in the mature phase than was belleved some ten or twenty years ago" 3). Kleine has compared several studies which refer to this relation between size and speed of adoption. Studies by Mansfield, Romeo and Globerman do verify this hypotheses, while in some other studies there is only a partial verification, e.g. for some countries or sectors. In some studies, notably by Bauberger and by Duchesneau, no relationship was found in a study by smith a significant positive relation between size and lag of adoption was found ${ }^{4}$ ).

The same holds for such factors as growth of firms and market atructure and competition. Several studies contradict each other and there is no clear evidence supporting relevant hypotheses.

1) Idem, p. 13 .

2) Idem, p, 21

3) G. Ray, 1984, p. 90.

4) See J. Klelne, 1983, pp. 99, 100. 
Many other factors such as access to information, RaD activitles, technical applicability of an imnovation, Ife-cycle of the relevant sector, qualification of labour and managerlal attitudes might be of some relevance as well.

\section{Measuring diffusion of information technology in process control}

Measuring the spread of Innovations can be done at four levels: intra-firm, intra-sector, inter-industry and the international level. In general only the first three levels of analysis are considered. Usually the rate of diffusion at any of these levels Is expressed in terms of capacity, employment or most frequently in terms of output or numbers of $f 1 r m s s^{1}$. Stoneman has presented a useful 11sting of the above mentioned levels of diffusion ${ }^{2}$.

- Intra-firm diffusion is measured as the change over time in the proportion of a firm's output produced on new technology. In case of a firm 1 in industry $f$, which produces a total output in time $t$ of $X_{1 j t}$, of which an output with new technology $Y_{1 f t}$, the intra-f1rm diffusion ratio is $\mathrm{Y}_{1 j \mathrm{t}} / \mathrm{x}_{1 j \mathrm{t}}$ which is assumed to approach the post diffusion ratio $\left(\mathrm{Y}_{1 j} / \mathrm{x}_{1 \mathrm{f}}\right)^{*} \leqslant 1$.

- Intra-sectoral (or inter-firm) diffusion regards the situation in which the output of firms produced on the new technology is compared to the total sector output, after the introduction of the innovation. Then $Y_{j t} / X_{j t} \Rightarrow\left(Y_{f} / X_{j}\right)^{*} \leqslant 1$.

- The least applicable ratio of these three measures 1 s related to inter-1ndustry diffusion which is a mere aggregation of inter-firm diffusion. In establishing this kind of diffusionratio one finds oneself confronted with the problem of comparing different sectors of Industry. As a consequence of the heterogeneous character of products in a cross-1ndustry comparIson it is in practice hard to find a discriminating measure. In case of research into diffusion of process 1 nnovations there is a tendency to take stocks of new capital goods as a proxymeasure ${ }^{3)}$.

1) See L Nabseth and G.F. Ray, 1974, p. B.

2) See P. Stoneman, 1983, PP. 67, 68.

3) Idem, p. 68 . 
In theory the best over-all Indicator of diffusion is found in consldering both intra and inter-firw diffusion-ratlo" 3.

Although output is probably the most elegant unt for expreseing diffusion-ratio"s it is not most frequently used as such. E.g. inter-firm diffusion is more often measured in terms of the percentage of companies in a spectfic Industry which apply a particular techn1que ${ }^{1)}$. This more we11-known standard for inter-firm diffusion expresses how $\mathbb{N}_{t}$ ( number of firms using a new technology) approaches $N_{t}{ }_{t}$ (post diffusion level of $\mathbb{N}_{t}$ ) or how $N_{t}$ as a proportion of the total number of firms approaches $\mathrm{N}^{*}$ expressed as a similar proportion ${ }^{2}$.

In survey research one is frequently on the mercy of the ability. (1nstitutional) memory and/or willingness of companies to provide information on diffuston. In this study of diffusion of information technology in process control measurement became somewhat more complicated as diffusion is IInked to technological development in terms of generations or technological trajectories.

In section 4.2 generations of each key-element of process control were characterfzed in terms of advancing stages of applied information technology. Hence, later generations are more soph1sticated In terms of information technology and the distribution of turnover for each generation of a key-element can be interpreted as an Indicator of the diffusion of information technology. In applying this method the importance of gradual improvement during the process of diffusion is stressed. Diffusion of information technology can be demonstrated in terms of an older generation, average practice and best practice technology. The activity of companies at the technological frontier is operationalized as their Involvement in RAD for coming generations ${ }^{3)}$.

The survey of the international process control equipment (p.c.e.) Industry included 56 compantes (see also Appendix I). In the following the development of diffuaion for each key-element is given for two years 1980 and 1985 . Compared to e.8. figure 4.4 dif furtion

1) See L. Nabseth and G.F. Ray, 1974, p. 8.

2) See P. Stoneman, 1983 , p. 68 . 3) For a description of generations for each key-element see table
4.1 . 
is not measured along the time axis but at two points in time. Extension of the period to e.g. 10 years was not feasible due to the lack of instututional memory in companies as far as particular, detalled information is concerned. Detalled information on diffustion from year to year would demand too much effort from particlpating companies: and ralse the non-response.

In the survey companies provided only relative distributions and no absolute figures. Compared to the levels of diffusion mentioned above the measurement of difusion which follows should be regarded as the average intra-sectoral rate of diffusion and the average rate of diffusion for different slze-classes. In other words, some extra Information 18 gained in comparison with a measure for the number of companies which apply a technology, but some information is lost in comparison with a straightforward intra-sectoral diffusion ratio.

As far as key-factors mentioned in the literature are concerned it will only be possible to search for a relation between industry structure, in terms of size-categories, and diffusion. With only a few exceptions most companies were reluctant to provide information on other key-factors such as profltability and financial resources, Furthermore, as for other findings of the survey, results have to be interpreted with some care as the information refers only to a limited number of compantes.

In the following 1 will discuss outcomes on diffusion of information technology for each key-element ${ }^{1)}$. First I will discuss the outcome for all companies which manufacture a key-element. This w11 be followed by a comparison of four categories of $11 \mathrm{e}^{2}$ ):

- small compantes with size upto 500 employees;

- medium alzed compantes with a size between 500 and 5,000 anployees;

- large companies between 5,000 and 50,000 employees; and

- very large companies with over 50,000 employees.

1) No information on diffusion of information technology in generations of production control systems can be provided. In fact all production control systems and management information systems are soph1sticated, best practice, technology.

2) The rationale of this particular division into categories of size $1 \mathrm{~g}$ discussed in chapter 5. 
Diffuston of Information technology in sensors generates a 'amooth' distribution which w11 not be found for any other keyelement, wee f1gure 4.6. In the survey 35 companies manufacture sensors. In the distribution of generatlons for a11 companies one observes a decline in the share of the older generation from 24 to $16 \%$.

Average practice sensors go from 75 to $78 \%$. The share of best practice sensors has developed from $1 \%$ in 1980 to $6 \%$ in 1985 . In other words, the diffusion of Information technology in sensors has been very moderate as far as the Introduction of smart sensors 1: concerned.

However, the diffusion of the most advanced level of Information technology increases wth the size of companies. Small companies do not manufacture micro-electronic integrated sensors and they apparently are not engaged in relevant research as well. For the other slze-categories an, albelt sme11, Increese in the share of smart sensors 18 visfble. All large and very large compantes conduct $R \& D$ at the technologlcal frontier of sensors. The modest rate of diffusion of best practice sensors reflects the of mentoned agnation in application and development of sophlsticated sensors.

Diffusion of information technology in hardwired (loglic) controllers follows a different path, see flgure 4.7 . There are 37 manufacturers of this device in the survey. Best practice technology, dedicated controllers, has been almost stable in the f1rst half of the eighties for the population as a whole. There has been a slight Increase in the share of best and average practice generatlons, consequently the share of obsolete generation has gone down to a mere $10 \%$. The pattern of diffuston, hovever, becomes very different for each tize-class.

For all lie-clases the share of older generation hardwired controllers has declined. For amal1 and medium sized companies tt has reached minimum level of about $5 \%$ in 1985. Large and very large compantes st111 manufacture a substantlal share of older generation controllers. 

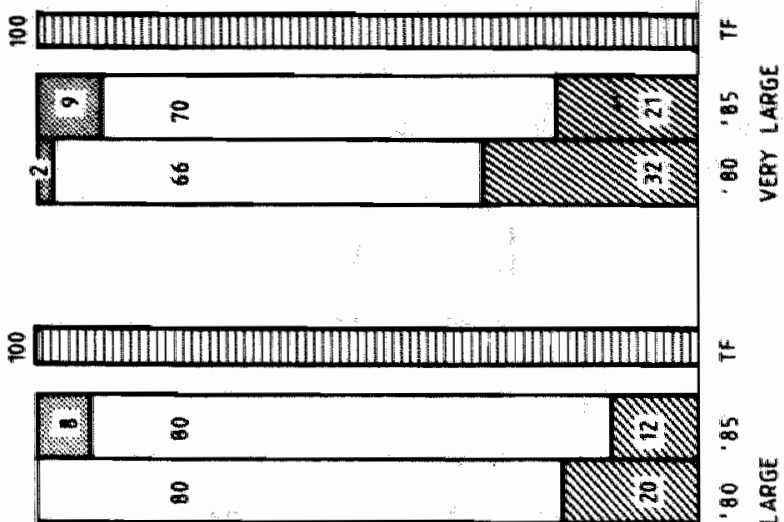

告

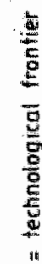

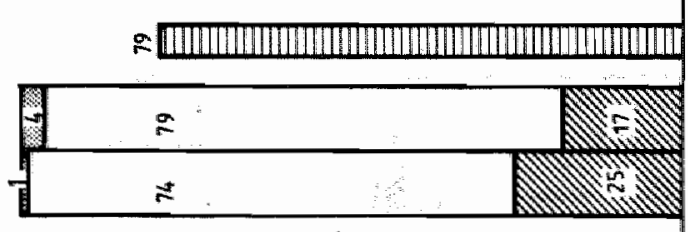

u

DIIID

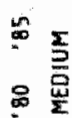

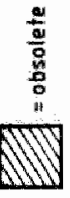

$\stackrel{\longleftarrow}{\longleftarrow}$

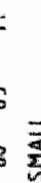

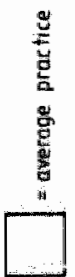

ఇ

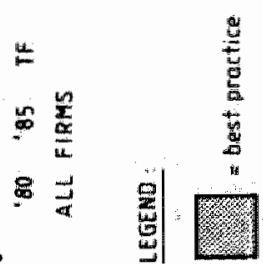



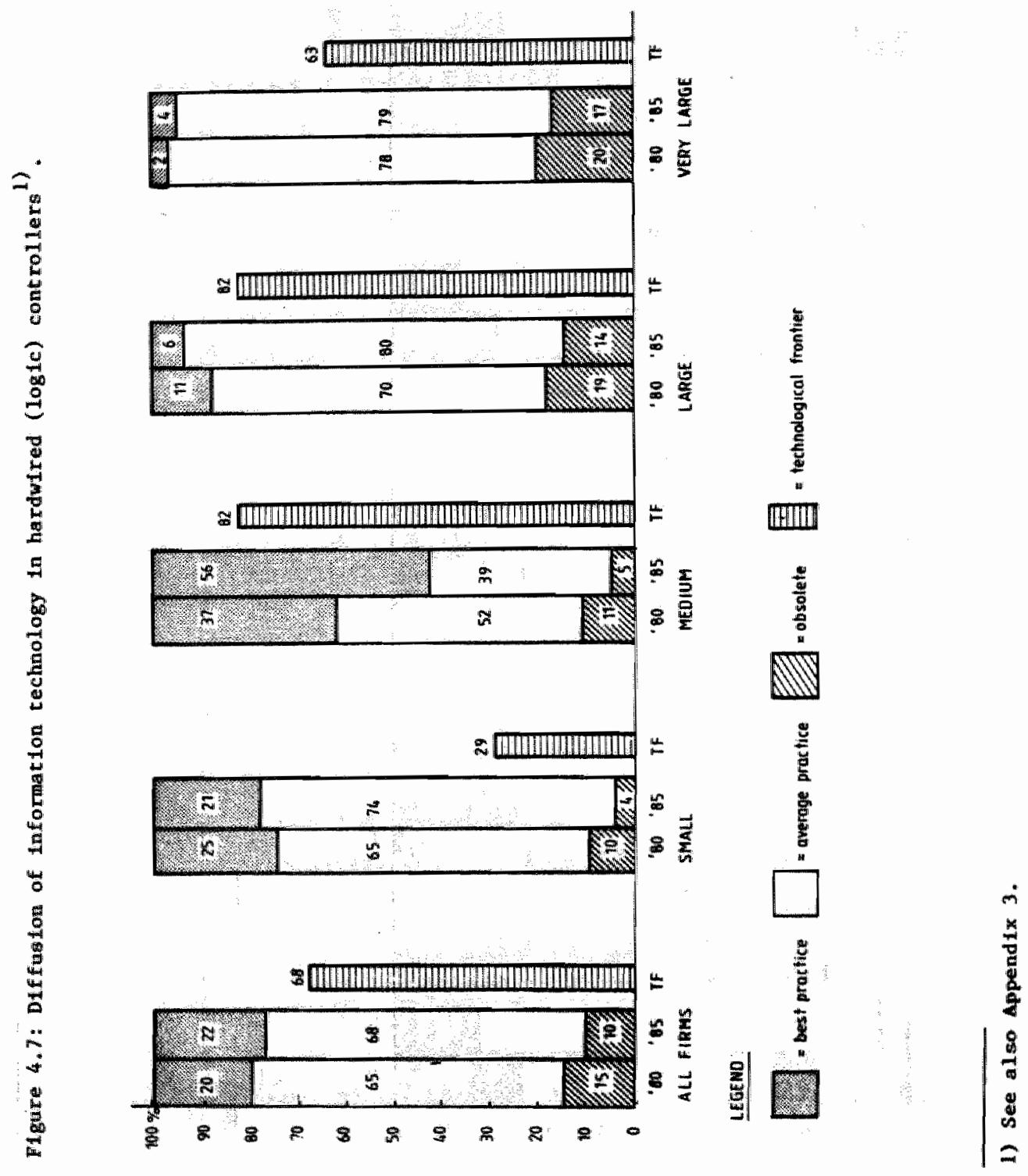
Small compantes show a rising share of average practice and a slightly decreasing percentage of best practice technology controllers. Diffusion of information technology in controllers as materfalized in 'dedicated controllers' has clearly been most advanced in the group of medium sized companies, where 1 t reaches share of $56 \%$ in 1985 .

Large and very large companies apparently concentrate their production of controllers on average practice technology which constitutes about $80 \%$ of the turnover for controllers. The share of best practice technology has elther declined, as for the large companies, or 1 t remalned at an Insignificant level as for the very large companies. Research at the technological frontier of dedicated controllers is performed by $68 \%$ of all companies, with only few small compantes, more than $80 \%$ of medium and large companies and over $60 \%$ of the very large companies.

Programmable Log1c Controllers (PLC's) have become 'stripped computers' which are able to perform many tasks which unt11 10-15 years could only be dealt with by computers. There are only a smal1 number of producers of these PLC's, in the survey there are only nineteen of them. Most of these manufacturers are large or very large companies.

For all companies a decline of the share of best practice technology and a Ilse of average practice technology PLC's $1 \mathrm{~s}$ clear, which could Indicate that demand for the most advanced generation is stagnating, see figure 4.8 .

Small companies demonstrate a shift from best practice and older generations to average practice which in 1985 takes a share of 55\%. Medium sized companies apparently concentrate virtually all their production at the level of average practice technology. The group of large and very large manufacturers are more tmportant. Large companies provide most of their PLC's with efther best practice or older technology. There has been a slight decrease of the older generation from 50 to $45 \%$, but no blgnlflcant change in the share of best practice technology. 


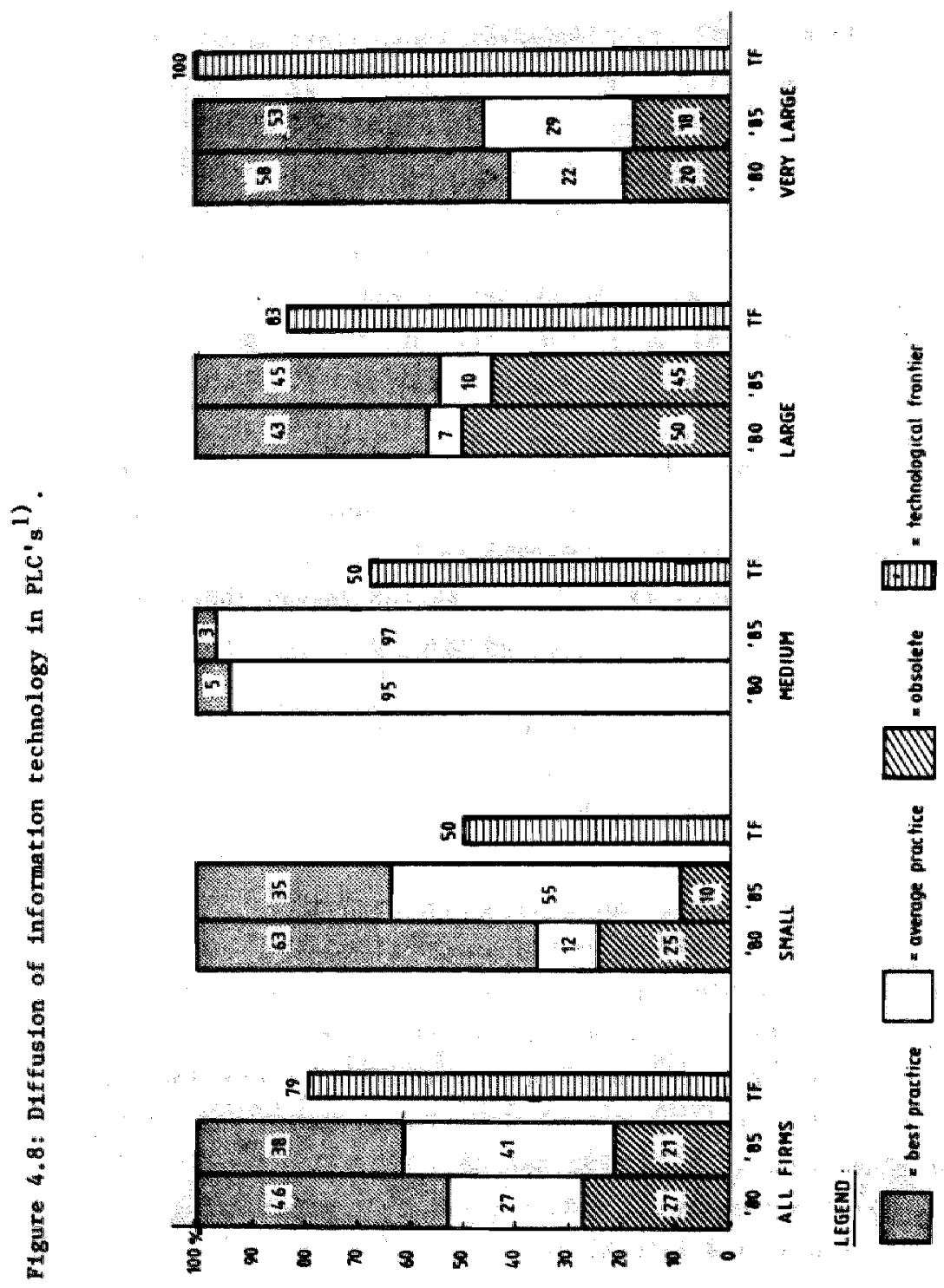


For the very large compantes it can be observed that best practice technology 1s, although with decreasing share, st111 well above $50 \%$. The share of older generations is fairly low and the share of average practice has risen to approximately $30 \%$.

Research at the technological frontier of $\mathrm{PLC}^{\prime} \mathrm{s}$ is a clear function of the size of companles as shown in increasing participation wth the increase of slze-classes.

For Process Control Systems growth in the share of best practice systems to over $50 \%$ can be observed in figure 4.9 . Thls growth is parallelled by a decline of both average practlce and older generations of control systems. Also most compantes (about 85\%) participate in research at the technological frontier.

There are some striking differences between in particular swall companies and the other size categories.

Small companies show a remarkable tncrease in the share of the older generation of centralized control systems of which the share has gone up to over $40 \%$. The share of best practice, digltalized distributed systems has dropped somewhat to fust over $30 \%$, but average practice technology has dropped from $37 \%$ to $26 \%$. Th1s could Indicate that small companies attempt to find 'new' markets for less sophlsticated systems for less developed process Industries or processing companies.

For other size categories 1t is clear that best practice technology has already reached a substantial level of diffusion: over $50 \%$ for medium sized, $60 \%$ for large and over $65 \%$ for very large companles.

For very large companies older generation systems with less deve1oped Imformation technology have dropped conelderably to an Insigniflcant level.

Average pract1ce technology for control systems has dropped or stabllized at a level of around $30 \%$. 


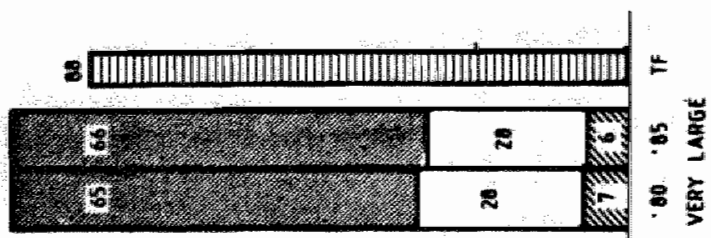

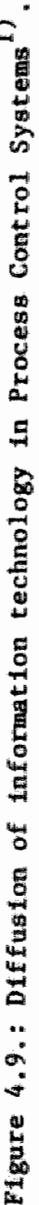
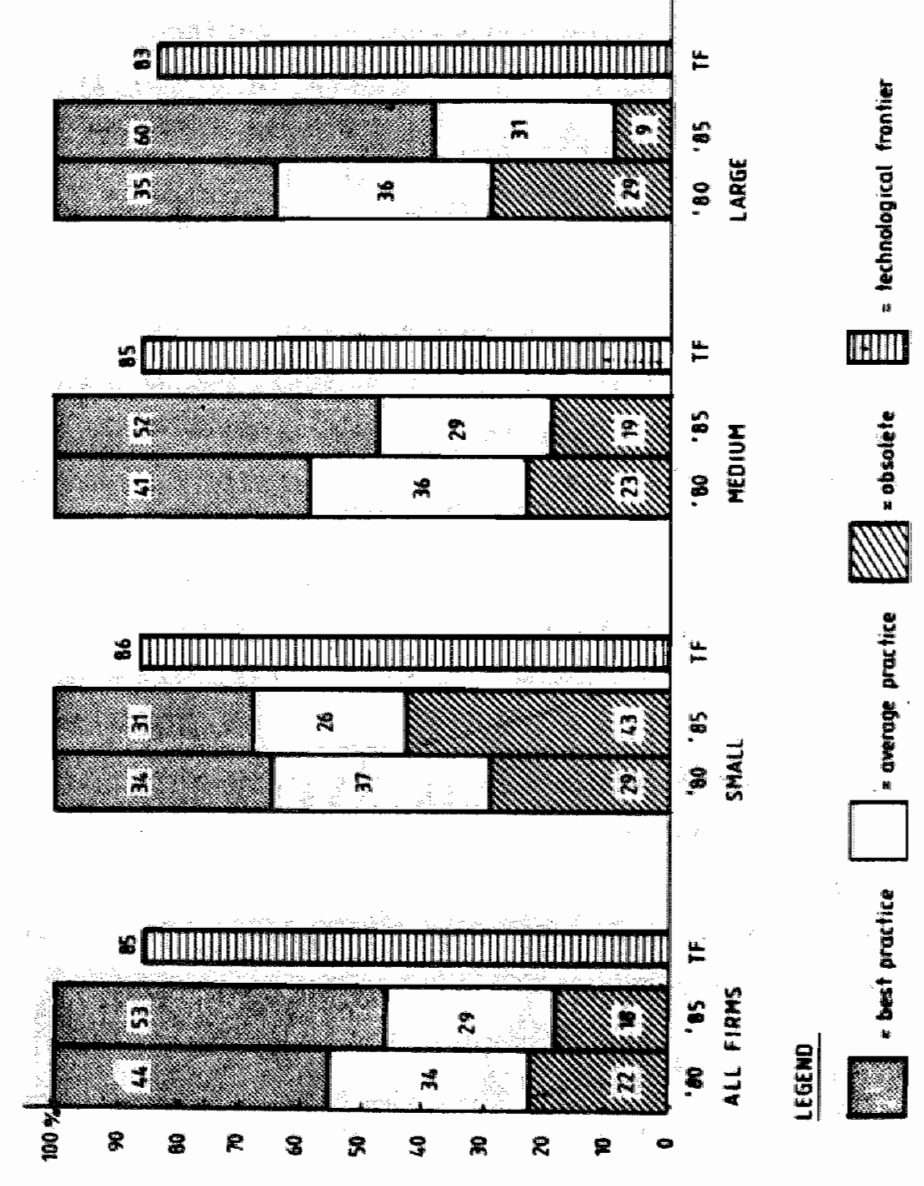
The analysis of diffusion coupled with technological trajectories at this level of detall has ajor advantage in the in-depth knowledge of diffusion of a particular technology. However it lso creates some problems regarding the interpretation of a more diffuse pattern as created in the above.

- Diffusion of advanced Information technology has different levels for each key-element. Diffusion of best practice technology has been very moderate in sensors, it is sagmating for controllers in so-called dedicated controllers, 1 thes even dropped back for PLC's, but has risen conslderably for process contral systers.

The diffusion of average practice technology has tncreased slightly for sensors and controllers but at an already high level of over $75 \%$ and over $65 \%$ respectively. It has gone up to over $40 \%$ for PLC"s and it dropped with $5 \%$ to $29 \%$ for process control systems.

The share of older generations of each key-element has been diminished to a share between 21 and $10 \%$ in 1985.

- For different size-classes some trends can be observed: Smal1 companies are hardly engaged in the production of sensors for which they concentrate on average practice technology without research at the technological frontier. They also reach a considerable share of average practice for controllere wh $a$, albelt alightly decreasing, reasonable share of best practice contrallers. In PLC's thelr share of best practlce has dropped cons1derably, but the share of average practice has been expanded substantially. For process control systems there has been rlse of older generations within the group of omall companies. So, in no key-element do small companies play an outstanding role in the diffusion of advanced Information technology.

The plcture is slightly different for medium slzed compantes. They concentrate on average practlce for sensors. In particular for PLC's, diffusion of best practlce information technology 
has been almost negligible. For hardwired controllers and process control systems the diffusion of information technology (In terms of the share of best practice controllers and digitalized control systems) has been considerable for medium sized compantes.

Large and very large companies dominate best practice technology and to a certaln extent also the technological frontier of three out of four key-elements. The only key-element in which both large and very large companles do not demonstrate a substantlal share of best practice technology is in the older technology of hardwired controllers for which dedicated controllers are an electronic new version. It has to be stressed that diffusion of sophisticated information technology in best practice generations and participation at the technological frontier has been most advanced in the group of the very large compantes.

4.4. DYNAMICS OF DIFFUSION AND TECHNOLOGICAL CHANGE

In the above the analysis of technological development has been integrated wth an analysis of diffusion. For both issues it was necessary to choose a theoretical and conceptual framework which is quite distinct from traditional economics. With this approach It appears to be possible to analyze both diffusion and technologtcal change. The analysts of technological paradigms and bastc desligns sets the general background for understanding technolog1cal development. Analysing technological change in key-elements, at Improwements of characterlatics of different generations, provides a clear identiflcation of technological trajectories. Technological trajectortes are also apparent in gradual improvements during process of diffusion. The economic and social Implications of technologlcal development is not mantfest unt 11 this process of diffusion takes place. Both diffuslon and technological change influence each other. In capitalist economies companles can be expected to seek only further improvement of technologles if the intra-firm diffusion of existing best practice technology generates returns from which further development can be 
financed. Within modern companles project-evaluation, declsion making and priority setting will, in particular in larger companies, not take place on a week-to-week basis but efforts to improve on best practice technology w111 be effected by the succes (diffusion) of exlsting technology. In the analysts of intrasectoral diffusion the linkage of technological progress to diffusion of best practice technologies reveil the endogenous character of technology. The dynamic aspects of this relation is reflected in the interdependence of both elements. In traditional. theorles of diffusion the dynamic aspect of this process is defined as the gradual growth in the number of adopters ${ }^{1)}$. In the context of this study this is seen as only one feature of the dynamics of technological and industrial development. For a further study of this relationship the understanding of technological development w111 have to be supplemented with an analysis of Industry structures and Innovation strategles of companies.

1) See e.g. C.G. Thirtle and V.W. Ruttan, 1987, P. 78. 
Having analysed jor technological developments effecting process control and diffusion of Information technology in amongst other things best practice applications of equipment and systems the next step 111 be to analyse Innovation in the process comtrol equipment (p.c.e.) Industry. In chapter 3 it was stressed that the relation between size, market otructure and Innovation is medlated by the technological opportunity and the 'age' of Industries. It was also mentioned that this technological opportuntty is influenced by the prociess of creative destruction which causes industries and companies to change. Therefore it will be necessary to first plcture this process of 1ndustrial and technological development and the companles which play a rolle in $1 t$.

Due to the lack of statistical data it will not be possible to reveal the relation between industrial concentration and Innovation. However, based upon the statistical material from the survey 1t w11 be posstble to pay extensive attention to the role different categories of companies play in generating innovation in this particular industry ${ }^{1)}$. In this analysis the relevance of a differentiation of companies not only in terms of size but also in referring to e.g. the1r 'age' and diversification patterns will be discussed. Innovation will be operationalized with some of the more well known research input Indfcators such as categories of RGD and some Indlcators of Innovation in terms of new products and best practice technology. In chapter 3 it was proposed to extend the analysis of Innovation and size of companies wh some attention to be pald to Innovation strategles followed by different categorles of companies. In this chapter innovation strategles of different categories of companies are analysed. It w11 be demonstrated that there appears to be no signlficant relation between

1) See Appendix 1 for detalls on the survey. 
size and Innovation strategtes, although there are some differences in the distribution of innovation strategles to different categoriles of size.

A survey of a limited number of companies restricts the possibl11ttes of statistical elaborations upon the materlal. As argued below the survey-population represents the international p.c.e. Industry with in particular the group of large, international companles included almost integrally. In order to be able to perform some simple statistical manipulations with a 1imfted number of respondents it w11 be necessary to restrict the ana1ysis to size-categories of compantes in a substantial share of the following. Also due to the small numbers and vartance in the statistics results will have to be interpreted with care.

\subsection{STRUCTURE OF THE PROCESS CONTROL EQUIPMENT INDUSTRY}

In the following paragraphs attention w111 be pald to changes in the Industrial structure during the past decades when some companies grew to considerable size. This growth and the identification of major companies is set against the background of technological changes analyzed in the previous chapter. Such changes in the industry have been substantial even if Schumpter's creative destruction took place only to a moderate degree.

The categorization of compantes in the industry is seen in the context of categories mentioned in the foregoing such as size, age, diversification and speclalization.

Industrial development and creative destruction in the p.c.e. Industry

The history of control technology and its industrial application in control equipment goes back at least as far as the nineteenth century. The introduction of steam powered machinery created the technical environment for further development of Industrial control. It led to number of inventions and the production of several control devices which gradually enabled the control of machines or processes without so-called direct manual control. 
After several decades of experimentation the introduction of electricity as an information transwitting wedium enabled the origin of a first stage of modern control technology in the early twentieth century. A gradually growing range of weasuring equipment and sensors such as thermocouples, 1ight sensitive cells and many pneumatic and hydraulic control devices were developed and manufactured by electrical and mechanical englneering companies.

In this perlod the growth of some of these early P.C.e. mamufacturers 18 clearly connected wth the role some entrepreneurs/ capitalists played in Innovating their business. In the leading company Honeywel1 entrepreneurs such as Albert Butz and in particular Mark Honeywel1 and Harold Sweatt resemble Schumpeter's conception of the entrepreneur and his role in capitalist soclety. In many other companles established in the late nimeteenth or early twentleth century the role of entrepreneurs 18 reflected in the names of companles such as Allen-Bradley, Emerson, Fischer \& Porter, Brown and Bover1, Hartmann and Braun. And although company records on these men can be mistrusted to certain extent as they present only one side of the picture it nevertheless becomes clear that entrepreneurs and entrepreneurlal capitalists played an important role in the industry during the first half of this century. With the growth of the industry and its companies the role of 'the' entrepreneur has clearly diminished, although sma11 companies have ploneered the development of several new process control products in the post-war period of growth ${ }^{1}$.

This growth has been effected by the growth of industries applying control 1nstrumentation. The gradual rise of process industries such a Iron and steel and chemicals caused growth in demand for P.c.e. A number of companies spectallzed in the production of this equipment and many of them grew with the increase of demand for more advanced control technology. In those days the industry already knew segnentation in larger compantes such as e.g. Honeywel1 and a group of sma11 and medtum sized compantes operating in sub-markets.

1) See e.g. D. Shimshoni, The moblle sclentist in the American instrument industry, In: Minerva, Vo1. 8, no 1, 1970. 
The first group of manufacturers produced not only individual pleces of equipment such as sensors and controllers they also supplled the early verstons of overall control systems. The growth of these leading companles, 11sted in table 5.1, resulted from both Internal growth (concentration) and centralfation through acquistitions and mergers. Company records of these corporations show a continuous process of acqulsitions, wergers, joint ventures, forelgn direct Investments and the building of new plants. The second group of compantes produced Individual devices which could either fit into a larger system or be applied in more simple single-loop control. Many of these companles were elther acquired by larger corporations or, in case they did not vanish, they remained in particular market niches.

As mentioned before the introduction of computer technology in the late fifties and early sixties caused a change of technological paradigm in the p.c.e. industry. Electromechanical instruments were replaced by electronlc devices and the gradual introduction of electronic controllers, micro-processors, and malnframe, mini and micro computers actually turned the p.c.e. Industry into sector closely related to the electronics industry. The differentiation of the industry became even more apparent as suppllers of control systems had to be able to integrate information technology into their systems and sub-systems and suppliers of single devices could elther offer advanced equipment to be 1inked to control systems or produce less advanced equipment for the lower end of the market. Many larger companies diversifled extensively. For some of them diversification atrategles, which began in the sixties, might have gone too far. In recent years a number of compantes such as Honeywe11, Gould and Combustion Engineering divested major businesses. Honeywell divested 1 to Information Dlvision into a folnt venture with Bull and NEC, Gould sold its Medical and Defence Divisions and Combustion Engineering 18 reshaping 1 ts activities to core-businesses. 


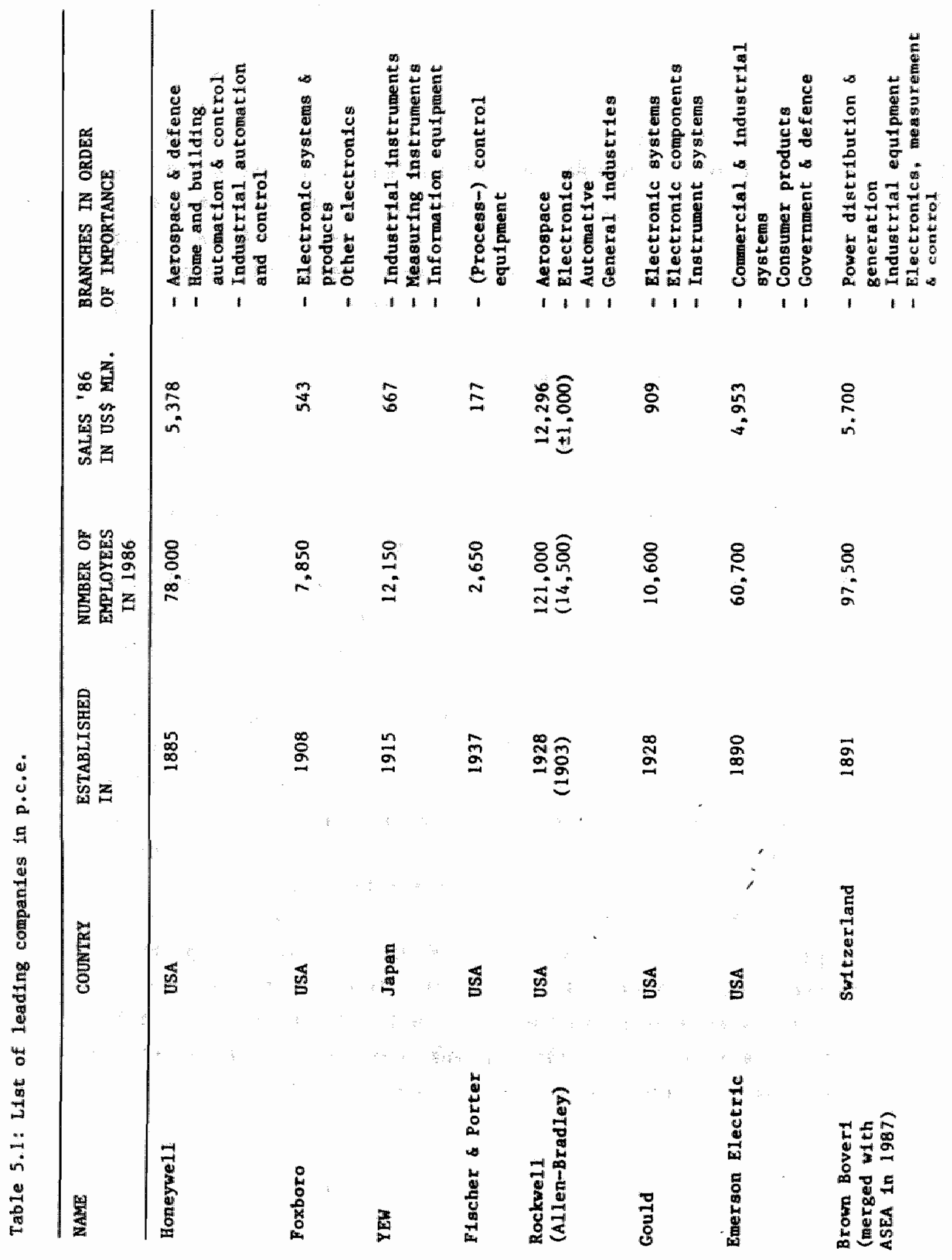




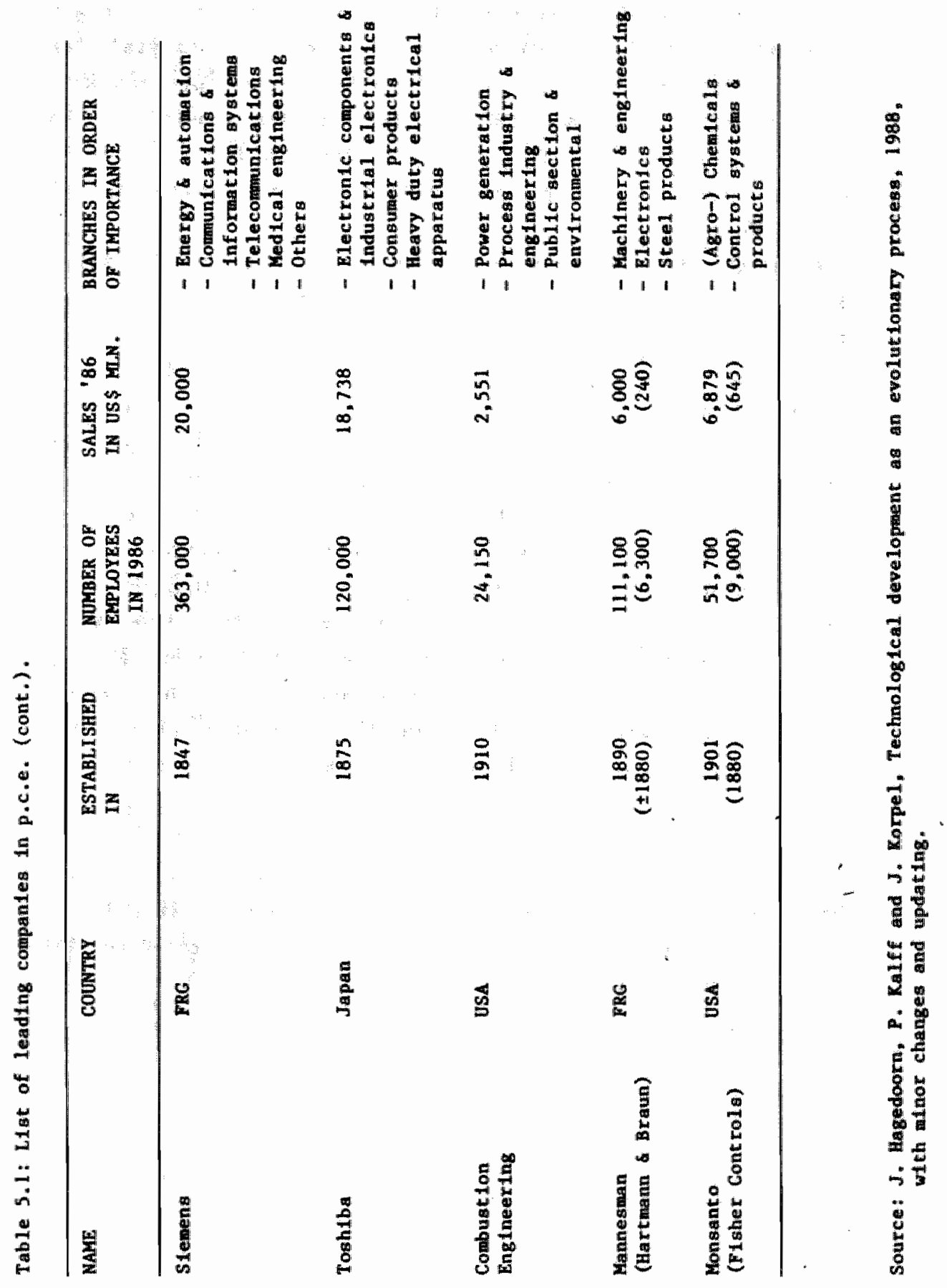


Nowadays most of the p.c.e. manufacturers still offer some of the "older" equipment for replacement purposes and for applications with less advanced customers. However, no company can be expected to "survive" in the industry without the ab111ty to integrate relevant sub-fields of Information technology into its products. A11 this has led to an Industry which has become more and more actence based. E. 8 . over $90 \%$ of the compantes atudied in the survey, 51 out of a total 56, are engaged in RED. Only three medium blzed and two larger companies reported no formal RsD (bee table 5.6).

The change-over to a more sclence based induatry and the transformation into an electronics-related sector has to a large extent been realized within existing p.c.e.-manufacturera and electronles compantes. Speclallzed computer companies and softwart houses do supply hardware and software for production controll and management information systems but their activities are to be seen as general system-architecture or top-level, computer-based, Information systems. Conpanies such as IBM, Digital, etc. are, however, not to be seen as suppliers of process control systems and therefore they do not appear in the 11st of leading companies in p.c.e. On the other hand some of the more widely diversifled p.c.e. manufacturers such as Slemens, Gould, Toshibs and Philips offer computersystems which can also serve within a complete production or process control system. The integration of information technology related activities and the creation of a broad spectrum of control products and systems in large p.c.e. manufacturers did not only take place in the reshaping of in-house capab1lities. As hown in table 5.2 many leading p.c.e. companies have been very active in acquiring relevant compantee in order to strengthen their technological competence in oophisticated control and information technology. 
Table 5.2: Take-overs of Information technology and p.c.e. related companies by major p.c.e. manufacturers since 1970 .

Gould acqulred:

- Biomation.

- Hydrosystems

- Modicon

- Dentison

- Hoffman Electrontes (a11 77)

- Deltec ('80 unt11"84)

- System Englneering Labs ('80)

- Taylor Electronics ('80 unt 11 ' 83 )

- SRL Medical

- Gettys Manufacturing

- Technicon's testing division

- De Anza Systems (all '81)

- American Micro Systems ("82)

- Bryons Southern Inst ruments

- Dexcel1 (both "83)

- International Cybemetics

- Micro Bond Technologies (both "85)

Emerson Electric acquired:

- Xomox

- Rosemount

- Micro Motion

- Automatic Switch Corp.

- Rlowa Corp.

- Uesh1ma (a11 - year unknown)

- Western Digital ('78)

- Smith Kline Beckman ("84)

- Copeland Corp. ('86)

- Hazeltine Corp. ('87)

Rockwe11 acquired:

- Allen - Bradley

- Robotrontes (both "85)

- 3M Corp. 's communications untt

- ECA (both '86)

Combustion EngIneerlng acqulred:

- Taylor Inst ruments ("83)

- Analytical Instr. Division from Alled Corp.

- Jamesburry

- Impel1 (al1 'BA)

- Sprout - Waldon

- Accu Ray ('86)
Honeywe11 acquired:

- $\mathrm{GE}^{\mathrm{s}} \mathrm{s}$ computer division

- Dienes (both 70)

- SAICOR ( 72$)$

- GE"s p.c.e. division ("74)

- Synertek ('78 unt 11 '84)

- Incotherm

- Spectronic

- skinner (a11 78)

- Electronics for Medicine

- Space-Kom (both 179)

- Megadyne ('80)

- A.C.S.

- Cometa (both '81)

- Tetra Tech

- ISSC (both "84)

Stemens acquited:

- Dickson ("74)

- Advanced Microdevices

- Litronix (both 77)

- Microware Semiconductors

- Databit (bath 79)

- Treshold Technology (' 80 )

- G.T.E. ('86)

Mannesmann scquired:

- Klenzle (year unknown)

- Hartmann \& Braun ('81)

- C. Bauer ('84)

Foxboro acquired:

- I.C.T. ('76)

- W11ks ('77)

- Jordan ('78)

- Octek ('83)

- Systrontes ("84)

Brown Bover1 acquired:

- George Kent (75)

Momsanto acquired:

- Fisher controls ('70)

- Posi-Seal Int. ('85)

Source: Annual reports, company proflles, various articles in speclalized foumels, L. Soete, Electronics, in L. Soete (ed.) 1985, pp. 22-23. 
The change of the p.c.e. sector and the creative destruction accompanyling 1t is not characterized by the general or substantiall destruction of the sector of Industry 1tself. However, there has been a moderate effect of creative destruction in the sense that the p.c.e. sector developed from measuring equipment and simple controls into 'high tech' sector. Leading companies have diversifled into electronlca and Information technology, some electronics companies have diversified or integrated smaller p.c.e. manufacturers. As demonstrated in chapter 4 also many small and medium sized companies have, although not always at the technological frontler, been able to apply more advanced forms of Information technology.

It 18 important to note that side entries and new compantes played but a moderate role in the reshap1ng of the industry after 1980 . As shown in table 5.1 most of the leading companies or their p.c.e. subsidiarles have been in the industry for a long perlod. Many typlcal p.c.e. manufacturers such as Honeywe11, Foxboro, YEW, Allen-Bradley, Hartmann \& Braun and Flsher Controls were established in the late nineteenth or early twentleth century. Even the "youngest" of the leading companies still have a history which goe back to the flrst decades of thls century. The near-absence of very recent (side-)entries is reflected in the "age" of p.c.e. production in the 56 companies from the survey. As can be read from table 5.3 over $70 \%$ of all companies were already manufacturing p.c.e. before 1970. Only four existing companies entered the market after 1979. Three of these are small companies and one entry refers to a large company. The latter is a stde entry of a diversifled company wh a relatively small pic.e. line of business ${ }^{1)}$. However, In the period from 1960 upto 1980 , with the emergence and perfection of the new computer-based paradigm in process control many companies have entered the industry. About 40\% of the companies in the survey, most of which amall or medium sized, entered the p.c.e. market in that particular period.

1) See J. Hagedoorn et a1., 1988, p. 166. 


\section{Different categories of $p . c . e$. companies}

The relevance of a differentiation of companies has been discussed extensively in chapter 3. Th1s led to a proposed framework of several categorles of companies based upon size and some other categorles such as new companies, subcontractors, and multinational and multidivisional companies. An Impression of the slze-distribution in the p.c.e. Industry is given in the bottom row in table 5.3. The four size-classes applied in this study have been constructed after information on the actual size of companies in terms of number of employees had been gathered. In many other studies categorles of size are frequently introduced beforehand and remain quite arbitrary. The size-classes in this study represent the actual sub-populations and clusters in a frequency distribution. Total employment of each company has been taken as an Indlcator of slze for several reasons. First, overall slze reflects the broader capabilities and activities of compantes which

Table 5.3: The 'age' of p.c.e. production, number of compantes and $\%$.

\begin{tabular}{|c|c|c|c|c|c|}
\hline & Total & 500 & $\begin{array}{c}\text { Overall } \\
500- \\
5,000\end{array}$ & $\begin{array}{l}5,000- \\
50,000\end{array}$ & $50,000+$ \\
\hline before 1950 & $\begin{array}{l}21 \\
37.5 \%\end{array}$ & $\frac{1}{7.1 \%}$ & $\frac{8}{42.1 \%}$ & $\begin{array}{c}7 \\
50.0 \%\end{array}$ & $\begin{array}{c}5 \\
55.5 \%\end{array}$ \\
\hline $1950-1959$ & $\begin{array}{c}9 \\
16.1 \%\end{array}$ & $\begin{array}{c}3 \\
21.4 \%\end{array}$ & $\begin{array}{c}2 \\
10.6 \%\end{array}$ & $\begin{array}{l}1 \\
7.1 x\end{array}$ & $\begin{array}{c}3 \\
33.3 \%\end{array}$ \\
\hline $1960-1969$ & $\begin{array}{l}11 \\
19.78\end{array}$ & $\begin{array}{c}5 \\
35.7 \%\end{array}$ & $15.8 \%$ & $\frac{2}{14.2 x}$ & $11.1 \%$ \\
\hline $1970-1979$ & $\begin{array}{l}11 \\
19.7 \%\end{array}$ & 14.38 & $3 i .6 \%$ & $21.3 \%$ & - \\
\hline after 1979 & $\begin{array}{l}4 \\
7.1 \%\end{array}$ & $21.4 \%$ & - & $\frac{1}{7.1 \%}$ & - \\
\hline Tata1 & $\begin{array}{c}56 \\
100 \%\end{array}$ & $\begin{array}{c}14 \\
100 \%\end{array}$ & $\begin{array}{c}19 \\
100 \%\end{array}$ & $\begin{array}{c}14 \\
100 \%\end{array}$ & $100 \%$ \\
\hline
\end{tabular}


due to Indivisibility cannot always be disaggregated into separate activities. Second, process control is not a distimetly administered Industrial activity for all companies in the survey and employment flgures for process control are 'rough' estimates for some compantes. Third, in Hagedoorn et al, 1988, both indicators of size, overall and p.c.e. employwent, have beem analysed generating but few differences in outcomes. All In all, overall size mppears sufflelent and reliable indicator to distingulsh between companies.

In the population of p.c.e. manufacturers there are fourteen small compantes, nineteen medium sized compantes, fourteen large companies and nine very large companies ${ }^{1)}$. For some other differentiations linto categories of companies the following remarks are to be made:

As already mentioned in the above new companies do not appear to be a relevant category for this particular industry at the present stage of 1ts development. If one abstracts from the large company which entered the p.c.e. market after 1979 there are only three sma11 firms in the survey which could have started as a new company after 1979.

Also subcontractors, companies which largely depend on intrasectoral trade and their 'jobbing' capacity, are not an important category in the industry. No company in the survey sold more than $75 \%$ of $1 \mathrm{ts}$ production to other p.c.e. manufacturers. Only two compantes depend for $50-75 \%$ of their turnover on sales to other p.c.e. producers. One of these compantes is small, the other is finedum sized but its p.c.e. activitles are of minor importance.

Like many other sectors of Industry the p.c.e. sector has become internationallzed in the past decedes. Nowadays many p.c.e. procuring compantes are large, world-wide operating, companies In process industries, consequently the arket is not restricted to national markets. This international character of the market

1) The group of small and medium sized companies are in a sense a 'sample' of the total population of such companies, the group of large and very large compantes are a close representation of those categories of p.c.e. manufacturers, see Appendix 1 . 
forced p.c.e. companies to at least Internationalize their marketing activities. Most of the companfes in the survey are wit1national in the strict sense implying that they hold offices in other countrles then their country of orlgin. Only a minority of companles, probably only seven small firms, are not multhational In that strlct sense. However, the large and very large comantes represent multinational companfes in the commonly accepted sense.

Most of the leading compantes from table 5.1 operate on transnational level with a network of world-wide manufacturing sites. asisembly factorles, local businesses and sales representatives.

Many of these companies are also multidivisional, diversffled companies but the multidivisionality and the degree of diversification differs from company to company. Electronlcs and electrical engineering companies such as Slemens, Philips, the new Brown Bover1-ASEA merger, Toshlba and to a certain extent also companies such as Rockwell, Gould, Emerson Electric and Combustion Engineering are diversiffed and multidivisional within the broad fleld of electronics, electrical englneering and defence systems. For most of these companies, in particular for the largest, control systems and Instrumentation represent only a small share of their total industrial activities, although such products are frequently integrated in other systems.

Honeyweli, once a specialized controls manufacturing company and st111 one of the leading companies, has developed to a multidivistonal company with businesses such as aerospace and defence, control systems and control products (Its information systems diviston merged with NEC of Japan and Bull of France in 1987). YEW, Foxboro and Fischer \& Porter are examples of more speclalized companles, although in particular the first two are diversifying Into electronics and a wider range of control systems for discrete manufacturing. Many well-known spectallzed p.c.e. flrms have become subsidlarfes of larger compantes. Hartman \& Braun and Fisher Controls have become backward Integrated subsidiartes of Manneswonn and Monsanto, respectively. Allen-Bradley became a subsidlary of Rockwell in 1985. Rosemount, Brooks Instruments and Beckmann have all been Integrated into Emerson Electric. Kent is substdiary of Brown Bovert and Combustion Engtneerlng owns Taylor Instruments, another well known p.c.e. manufacturer. 
Spectallitation and diversification in the p.c.e. Industry can also be seen in table 5.4 wich gives somewhat different picture than would probably be expected. It is remarkable that small companies are on average almost as little speclalized in p.c.e. as the group of very large companles, although the coefficient of varlation for very large compantes indicates that specialization in puc.e. varles considerably for the group of very large companies. Small compandes have about $30 \%$ of their turnover in p.c.e.; metal products, micro-electronics and other electronics are product groups that small companles have diversifled 1nto. Very large compantes are diversiffed Into p.c.e., other electronic capttal goode and a wider array of products. Both medium sized and large companies concentrate on average about $50 \%$ of their turnover on p.c.e. which turns both groups into relatively 'specialized'. For medium slzed compantes other electronle capltal goods are Important as well, for larger companies metal products take a substantial share of the turnover.

Within p.c.e. there is a differentiation of companties according to specialization in the number of key-elements. As shown in table 5.5 only 10 companies produce all 5 key-elements of p.c.e. Some companies (3) produce p.c.e. but none of the key-elements which can only mean that they produce particular devices and instruments of minor 1 mportance to p.c.e. From table 5.5 it becomes clear that larger companies tend to produce more key-elements. Most small compantes spectalize in a smaller range of key-elements.

If the structure of the p.c.e. Industry has to be characterized in a few words the followling can be mentioned: the industry and its companies can be divided into four size categories, small, medium slzed. large and very large. New companies, recent side-entries and subcontractors do not play an important role. A relatively small number of large and very large multinational and multidivisional corporations operate within this industry. Many of the well-known speclalized companies have been integrated into these compantes. Small and very large companies are more widely diversifled than the other two classes of companies. However, within p.c.e. production the larger a company the more key-elements it w11 probably produce. 


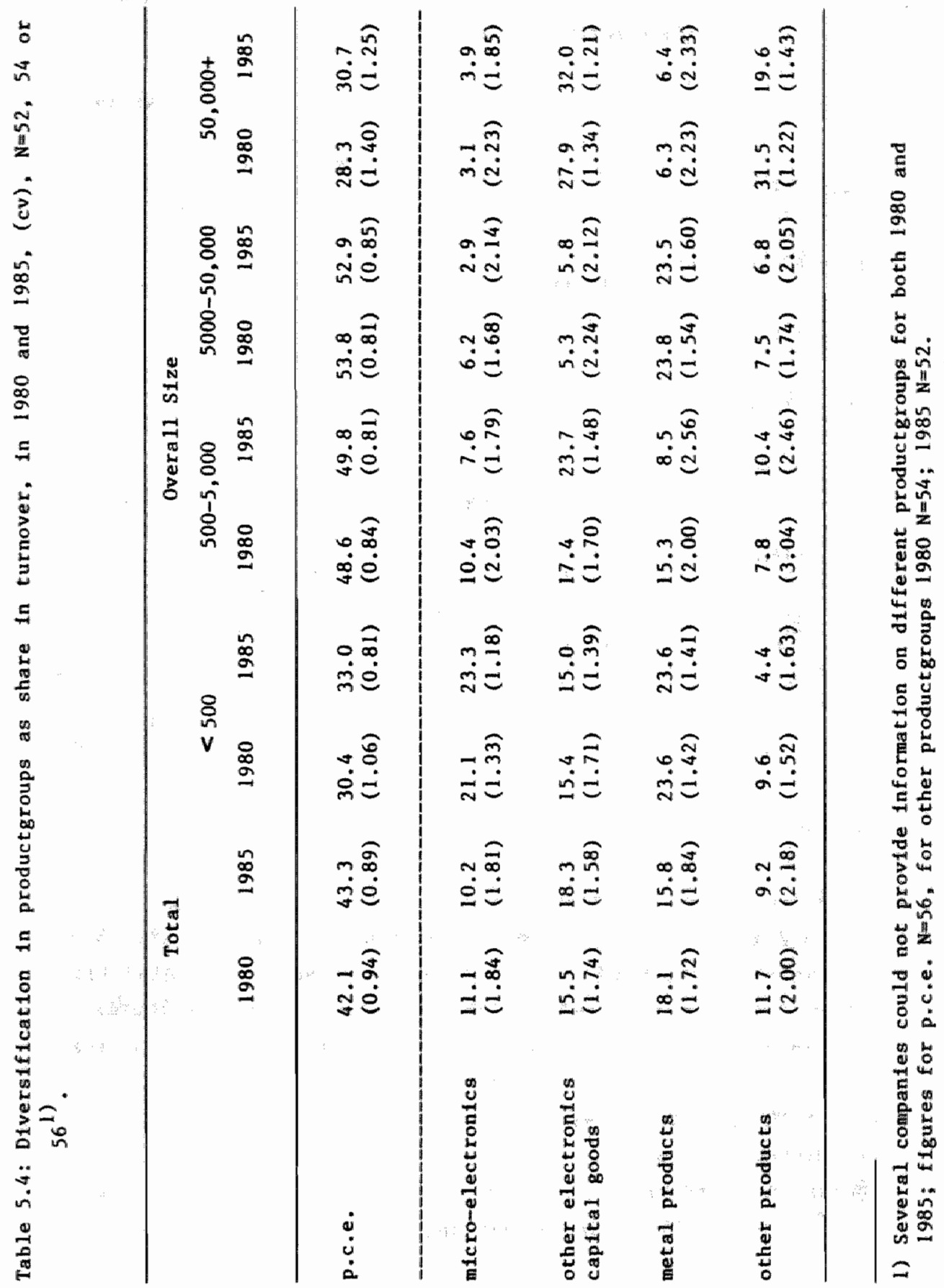


Table 5.5: Speclallzation whin p.c.e.; comblnations of production of sensors, HWC's, PLC"s, process contral systems and software for production control systems, number of suppllers and \%

\begin{tabular}{|c|c|c|c|c|c|}
\hline Combinations: & Total & 5 & $\begin{array}{c}\text { Overal1 } \\
500- \\
5,000\end{array}$ & $\begin{array}{l}\text { S1ze } \\
5,000- \\
50,000\end{array}$ & $50,000+$ \\
\hline Al1 is key-elements & $\begin{array}{l}10 \\
17.8 \%\end{array}$ & - & $\frac{2}{10.5 \%}$ & $\begin{array}{l}2 \\
14.3 \%\end{array}$ & $\begin{array}{l}6 \\
66.7 \%\end{array}$ \\
\hline 4 key-elements & $\begin{array}{l}16 \\
28.6 \%\end{array}$ & $\begin{array}{c}3 \\
21.4 \%\end{array}$ & $\stackrel{6}{31.6 \%}$ & $\begin{array}{c}7 \\
50.0 \%\end{array}$ & - \\
\hline 3 key-elements & $\begin{array}{l}10 \\
17.8 \%\end{array}$ & $\frac{3}{21.4 \%}$ & $\begin{array}{c}4 \\
21.1 \%\end{array}$ & $\begin{array}{l}2 \\
14.3 \%\end{array}$ & $11.1 \%$ \\
\hline 2 key-elements & $\frac{9}{16.2 \%}$ & $\begin{array}{c}4 \\
28.6 \%\end{array}$ & $\begin{array}{l}1 \\
5.3 \%\end{array}$ & $\stackrel{2}{14.3 \%}$ & $\stackrel{2}{22.2 \%}$ \\
\hline 1 key-element & $\begin{array}{c}8 \\
14.3 \%\end{array}$ & $\frac{3}{21 \cdot 4 \%}$ & $\begin{array}{l}5 \\
26.3 \%\end{array}$ & - & - \\
\hline 0 key-element & $\begin{array}{c}3 \\
5.4 \%\end{array}$ & $\frac{1}{7.1 \%}$ & $\begin{array}{l}1 \\
5.3 \%\end{array}$ & $\frac{1}{7.1 \%}$ & - \\
\hline Total & $\begin{array}{c}56 \\
100 \%\end{array}$ & $\begin{array}{c}14 \\
100 \%\end{array}$ & $\begin{array}{c}19 \\
100 \%\end{array}$ & $\begin{array}{c}14 \\
100 \%\end{array}$ & $\begin{array}{c}9 \\
100 \%\end{array}$ \\
\hline
\end{tabular}

5.3 SIZE AND IMNOVATION IN THE P.C.E. INDUSTRY

In chapter 3 the so-called Schumpeter controversy in the literature and research-findings on the relation between flrm size and Innovation has been discussed. Several hypotheses regarding the subject have been deducted from the 1fterature. In the following I wil relate the size of companles as found in the survey of the p.c.e. Indugtry to several indicators of Innovation. The diatribution of size classes w111 be related to innovation-1nputa, 1.e. the distribution of basic and applied research and product development, followed by the analysis of the relation between size and RAD Intensity. Innovation-output indicators are applied for the 
relation between size and the share of new products in company turnover. These output Indicators will be briefly compared to the findings on the distribution of best practice genergtions of p.c.e. as reported more extensively in chapter $4^{1}$.

S1ze and R\&D

The distribution of research inputs is the first indicator for Innovation. In table 5.6 the distribution of categorles of RAD such as basic, applied and product development is reported. 51 compantes, about $90 \%$ of the companies, perform RAD whtch confirms the science-based character and to a certain extent also the general technological opportunity of the 1ndustry. Most of the research 1 s devoted to both applied research and product development. Only $13 \%$ of the funds for R\&D is used for basic research. However some qualifications have to made. For the population as a whole as well as for the sub-categorles of size the coefficients of variation polnt out that there is much scatter in the percentage of baslc research. These outcomes also refer only to relative distributions of $R \& D$ and not to absolute figures or RGD as a percentage of e.g. sales. In other words, the actual spending of RSD is unknown, which could have changed the plcture. Furthermore, companies might have different perceptions of categorles of RGD. Keeplng in mind such considerations some marked results for different size-classes can be observed.

The group of small compantes applies on average only $25 \%$ of their funds for product development, while the larger compantes distribute over $50 \%$ of their funds to product development. From the d1stribution of funds for bastc research one learns that under conditions of quite Identical coefficlents of variation small companles

1) One particular Indicator of inmovation output, frequently mentioned in the 11terature, refers to the number of patents per firm or the distribution of patenting companies. In the survey of the p.c.e. Industry too few companles seattered throughout the population reported to have applied for patents in the past years. Due to these small numbers plus the wide variation in patenting-activity it is impossible to draw any conclusions from the material. 
concentrate much more of their R\&D funds on basic research. Small p.c.e. manufacturers spend on average about $50 \%$ of their RaD funds on applied research, and about $25 \%$ on basic research and product development each. Medium-sized and large companies concentrate most of their research on applied research and product development ( $\$ 90 \%)$ and spend relatively few of their funds on baslc research. The finding for the group of very large companles come very close to results from other studles on large and very large companies. E.g. In an EIRMA study on RGD expenditures by over 100 large compantes bimllar results were generated: basic research $9 \%$ (p.c.e. 11\%), applied research $32 \%$ (p.c.e. 34\%), development $59 \%$ $(\text { p.c.e. } 55 \%)^{1)}$.

Table 5.6: Distribution of categories of research in \% of total research in 1985 .

\begin{tabular}{|c|c|c|c|c|c|}
\hline & Tota 1 & 500 & $\begin{array}{c}\text { Overal1 size } \\
500- \\
5,000\end{array}$ & $\begin{array}{l}5,000- \\
50,000\end{array}$ & $50,000+$ \\
\hline \multicolumn{6}{|c|}{ Baslc research: } \\
\hline $\begin{array}{l}\text { average \% } \\
\text { cv }\end{array}$ & $\begin{array}{l}13 \\
1.5\end{array}$ & $\begin{array}{l}24 \\
1.2\end{array}$ & 12 & $\begin{array}{l}7 \\
1.3\end{array}$ & $\begin{array}{l}11 \\
1.1\end{array}$ \\
\hline \multicolumn{6}{|l|}{$\begin{array}{l}\text { Applied } \\
\text { research: }\end{array}$} \\
\hline $\begin{array}{l}\text { average } \% \\
\mathrm{cv}\end{array}$ & $\begin{array}{l}43 \\
0.6\end{array}$ & $\begin{array}{l}51 \\
0.6\end{array}$ & $\begin{array}{l}41 \\
0.6\end{array}$ & $\begin{array}{l}42 \\
0.8\end{array}$ & $\begin{array}{l}34 \\
0.6\end{array}$ \\
\hline \multicolumn{6}{|c|}{$\begin{array}{l}\text { Product } \\
\text { development : }\end{array}$} \\
\hline $\begin{array}{l}\text { average } \% \\
\mathrm{cv}\end{array}$ & $\begin{array}{l}44 \\
0.7\end{array}$ & $\begin{array}{l}25 \\
0.9\end{array}$ & $\begin{array}{l}47 \\
0.6\end{array}$ & $\begin{array}{l}51 \\
0.6\end{array}$ & $\begin{array}{l}55 \\
0.5\end{array}$ \\
\hline Tota1 & $100 \%$ & $100 \%$ & $100 \%$ & $100 \%$ & $100 \%$ \\
\hline $\begin{array}{l}\text { Number of } \\
\text { compantes } \\
\text { wteh RdD } \\
\text { of total }\end{array}$ & $\begin{array}{l}51 \\
91 \%\end{array}$ & $\begin{array}{c}14 \\
100 \%\end{array}$ & $\begin{array}{l}16 \\
84 \%\end{array}$ & $\begin{array}{l}12 \\
86 \%\end{array}$ & $\begin{array}{c}9 \\
100 \%\end{array}$ \\
\hline
\end{tabular}

1) See EIRMA, How much RAD?, 1983, p. 50 . 
In tabel 5.7 the research intensity of p.c.e. manufacturers $1 \mathrm{~s}$ presented. It is clear that the research intensity is quite identical for three out of four size-classes. The group of small companies appears to be more research intensive than the other classes, but there is substantial variation in research intensity of small companies. In other words, a substantial part of the group of small companies probably belongs to the class of highly research intensive small flrms mentloned by Freeman.

Table 5.7: Research Intensity (share of number of R\&D employees in total number of employees) in 1985.

\begin{tabular}{|c|c|c|c|c|c|}
\hline & Total & 500 & $\begin{array}{c}\text { Overall } \\
500-5,000\end{array}$ & $\begin{array}{l}\text { S1ze } \\
5,000- \\
50,000\end{array}$ & $50,000+$ \\
\hline $\begin{array}{l}\text { Research } \\
\text { Intensity }\end{array}$ & 0.09 & 0.18 & 0.05 & 0.06 & 0.06 \\
\hline c.v. & 1.4 & 1.12 & 1.04 & 0.81 & 0.89 \\
\hline
\end{tabular}

S1ze_and product-related indicators of innovation

Since innovation is generally defined as an invention that has been introduced to the market, innovativeness can be measured by the share of turnover that is generated by new products. In tables 5.8 and 5.9 the share of the 1985 turnover for new products, introduced after 1980, Is set against the different size classea. In table 5.8 the category new products 18 defined as new to the company, in table 5.9 new refers to new to the market.

In table 5.8 it is shown that only one small company stated that new products did not contribute to 1 ts turnover. Over $40 \%$ of the companies mentioned that $50 \%$ or more of their turnover in 1985 resulted from the introduction of new products. The group of sma11 companies and the largest companies have been most innovative in terms of the share of new products in 1985 turnover. 
Table 5.8: Share of companies new products in 1985 turnover for p.c.e

\begin{tabular}{|c|c|c|c|c|c|}
\hline & Total & 500 & $\begin{array}{l}\text { Overal1 } \\
500- \\
5,000\end{array}$ & $\begin{array}{l}\text { size } \\
5,000- \\
50,000\end{array}$ & $50,000+$ \\
\hline $\begin{array}{l}\text { no new } \\
\text { products }\end{array}$ & $\begin{array}{l}1 \\
1.8 \%\end{array}$ & $\frac{1}{7.1 \%}$ & - & - & - \\
\hline Iens $10 \%$ & $\begin{array}{l}11 \\
19.7 \%\end{array}$ & $\frac{2}{14.3 x}$ & $\begin{array}{c}5 \\
26.3 \%\end{array}$ & $\begin{array}{c}3 \\
21.3 \%\end{array}$ & $\frac{1}{11.1 \%}$ \\
\hline $10-50 \%$ & $\begin{array}{l}20 \\
35.6 \%\end{array}$ & $\frac{3}{21.4 \%}$ & $\begin{array}{c}9 \\
47.4 \%\end{array}$ & $\frac{5}{35.6 \%}$ & $\frac{3}{33.3 \%}$ \\
\hline $50 \%+$ & $\begin{array}{l}24 \\
42.9 \%\end{array}$ & $\begin{array}{l}8 \\
57.1 \%\end{array}$ & $\begin{array}{c}5 \\
26.3 \%\end{array}$ & $\begin{array}{c}6 \\
42.9 \%\end{array}$ & $\stackrel{5}{55.5 \%}$ \\
\hline Total & $\begin{array}{c}56 \\
100 \%\end{array}$ & $\begin{array}{c}14 \\
100 \%\end{array}$ & $\begin{array}{c}19 \\
100 \%\end{array}$ & $\begin{array}{c}14 \\
100 \%\end{array}$ & $\begin{array}{c}9 \\
100 \%\end{array}$ \\
\hline
\end{tabular}

A probably even more sultable lmdicator is found in the share of 'really new' products, 1.e. products introduced since 1980 that were new to the market and not only to the company itself. These flgures are shown in table 5.9. It is evident that the share of turnover reallzed with these really new products is lower than with the products mentioned in the previous table. Elght companies mention that new products have had no share in their 1985 turnover. Only three medium-slzed companies clatm to have generated at least $50 \%$ of their turnover in 1985 with new-to-the-market products.

If a minimu of $10 \%$ of the turnover realized with real new products $1 \mathrm{~s}$ accepted as reasonable indicator of the innovativeness of compantes, then the groups of mall and very large compantes are most innovative as:

- Over $60 \%$ of the group of small compantes reach the winlmum level of $10 \%$.

- Over $50 \%$. 5 out of 9 , of the group of the very large companies achleve the same minfmum. 
Table 5.9: Share of companies' new to the market products in 1985 turnover for p.c.e.

\begin{tabular}{|c|c|c|c|c|c|}
\hline & Total & 500 & $\begin{array}{l}11 \text { size } \\
500- \\
5,000\end{array}$ & $\begin{array}{l}5,000- \\
50,000\end{array}$ & $50,000+$ \\
\hline $\begin{array}{l}\text { no new } \\
\text { products }\end{array}$ & $\begin{array}{c}8 \\
14.3 \%\end{array}$ & $\stackrel{2}{14.3 \%}$ & $\begin{array}{l}1 \\
5.3 \%\end{array}$ & $\begin{array}{c}4 \\
28.6 \%\end{array}$ & $\frac{1}{11.1 \%}$ \\
\hline less $10 \%$ & $\begin{array}{l}23 \\
41.0 \%\end{array}$ & ${ }^{3} 1.4 \%$ & $\begin{array}{l}10 \\
52.6 \%\end{array}$ & $\stackrel{7}{50.0 \%}$ & $\stackrel{3}{33.3 \%}$ \\
\hline $10-50 \%$ & $\begin{array}{l}22 \\
39.3 \%\end{array}$ & $\begin{array}{l}9 \\
64.3 \%\end{array}$ & $\begin{array}{l}5 \\
26.3 \%\end{array}$ & $\begin{array}{c}3 \\
21.3 \pi\end{array}$ & $\stackrel{5}{55.5 \%}$ \\
\hline $50 \%+$ & $\begin{array}{l}3 \\
5.4 \%\end{array}$ & - & $\begin{array}{l}3 \\
15.8 \%\end{array}$ & - & - \\
\hline Total & $\begin{array}{c}56 \\
100 \%\end{array}$ & $\begin{array}{c}14 \\
100 \%\end{array}$ & $\begin{array}{c}19 \\
100 \%\end{array}$ & $\begin{array}{c}14 \\
100 \%\end{array}$ & $\begin{array}{c}9 \\
100 \%\end{array}$ \\
\hline
\end{tabular}

The diffusion of best-practice technologies reported in chapter 4 can also serve as an indicator of Innovativeness. It has been reported that small companies play only a minor role in the generation of best-practice technologies. Large and in particular very large companies are most innovative from the perspective of best-practice technologies and technological frontiers in p.c.e. Medium sized companies take a position in between the groups of sma11 and large companies.

In order to achleve a more aggregate indicator of best-practice performance the percentages of turnover for best practlce of each key-element supplied by a company can be added and devided by the number of key-elements it produces. Through this simple procedure one is able to have an overall indicator of each company which can be added for different size-classes as shown in table $5.10^{1}$ ).

1) See Appendix 6 for individual records. 
It follows from this table that the group of the very large companies have been most innovative in terms of best practice technology in the key-elements they produce. Small companies are elearly less advanced in terms of diffusion of best practice technology than the other classes. Medium and large companies take an intermediate position.

Table 5.10: Share of best practice technology in all key-elements supplied by p.c.e.

\begin{tabular}{|c|c|c|c|c|c|}
\hline & Total & 500 & $\begin{array}{l}11 \text { size } \\
500- \\
5,000\end{array}$ & $\begin{array}{l}5,000- \\
50,000\end{array}$ & $50,000+$ \\
\hline $\begin{array}{l}<20 \% \\
\text { best practice }\end{array}$ & $\begin{array}{l}24 \\
42.9 \%\end{array}$ & $\begin{array}{l}8 \\
57.1 \%\end{array}$ & $\begin{array}{c}8 \\
42.1 \%\end{array}$ & $\begin{array}{l}6 \\
42.9 \%\end{array}$ & $\stackrel{2}{22.2 \%}$ \\
\hline $\begin{array}{l}20-40 \% \\
\text { best practice }\end{array}$ & $\begin{array}{l}19 \\
33.9 \%\end{array}$ & $\begin{array}{c}4 \\
28.6 \%\end{array}$ & $\begin{array}{l}6 \\
31.6 \%\end{array}$ & $\begin{array}{c}5 \\
35.6 \%\end{array}$ & $\begin{array}{l}4 \\
44.4 \%\end{array}$ \\
\hline $\begin{array}{l}>40 \% \\
\text { best practice }\end{array}$ & $\begin{array}{l}13 \\
23.2 \%\end{array}$ & $\stackrel{2}{14.3 \%}^{2}$ & $\begin{array}{c}5 \\
26.3 \%\end{array}$ & $\begin{array}{c}3 \\
21.3 \%\end{array}$ & $33.3 \%$ \\
\hline Total & $\begin{array}{l}56 \\
100 \%\end{array}$ & $100 \%$ & $\begin{array}{l}19 \\
100 \%\end{array}$ & $\begin{array}{l}14 \\
100 \%\end{array}$ & $100 \%$ \\
\hline
\end{tabular}

5.4 INNOVATION STRATEGIES IN THE INDUSTRY

General trends of technological development in process control, in particular the further integration of several aspects of soph1st1cated information technology, return in the major topics in the Innovation and ROD strategles of the leading companies. It will be clear that these compantes do not provide detalled information on their RaD activitles. However, annual reports, company proftles and interviews with management reveal some of the main topics of research in the Industry.

All leading companies mentioned in table 5.1 perform research at the technological or sclentific frontier of at least some of the $18 s u e s$ mentioned below. The largest companies and those engaged in several sub-disctplines of information technology cover virtually 
all these coptcs. Smaller and more speclallzed companles appear to concentrate on a smaller number of research 1tems. These toplcs picture a stable set of commitments and broadly defined Innovation targets for the nearby future.

The following copics, rangling from direct process measurement to overall production control, are worth mentioning:

- research on the combination of sensors and advanced alcroelectrondes (smart sensors);

- further digltalization of stand-alone equipment;

- integration of computer and communication technologies with e.g. local area networks and speech recognition systems;

- advanced computer science which does not only include hardware and micro-electronics but also advanced software, artiflctal Intelligence and expertsystems.

For the next step in the analysis of innovation strategies 1 w11 be necessary to assess the relevance of a number of innovation strategles, mentioned in chapter 3 , in the context of the P.c.e. industry. One strategy, the traditional strategy, can be disregarded before hand as the modern p.c.e. Industry has 11ttle in common with handicrafts. In a prevlous section it also became clear that subcontractors do not play a role of any importance in the present population which makes it unnecessary to pay attention to the dependent strategy. An opportunist strategy could be reflected in the degree of speclalization into one key-element as shown in table 5.5. However, the degree of diversification into other product groups outside p.c.e., shown in table 5.4, suggests that only very few companies w11 follow an opportunist strategy defined in chapter 3 .

All this leads to a set of alternative trategles, offensive, defensive or imitative, which can be analysed for the Industry structure of the p.c.e. Industry. In the following a princlpal components analysis 1 s applied to identify the relation between classes of size and Innovation strategies ${ }^{1)}$. To operationilize

1) See e.g. A. v.d. Zwan and J. Verhulp, Grondslagen en technieken van de arktanalyse, 1980 and F.N. Rerlinger, Foundations of behavioral research, 1969 for brief descriptions of factor analyses. 
these strategles a nubber of varlables were ldentifled. Most of these varlables were also applied in the previous section. In the final principal components analysis flve variables have been introduced: research 1ntensity (RDINT), research intensity in p.c.e. as the share of $R G D$ employees for p.c.e. In total number of p.c.e. employees (RDINTPCE), share of new products in turnover (NEW PROD), share of new-to-the-market products 1n turnover (REALNP), and the average rate of best practice in key-elements produced (BESTPRAC).

In princlpal components analysis the gmallest possible number of Inear comblnations of components which together explain a maximum degree of (standardized) vartance 1s sought. The proportion of explafned variance (communalfty) is applied as a measure of goodness of fit. Princlpal components analysis is a technique for datareduction e.g. to measure one scale for a number of indicators. (variables) at which all elements take a position. In this study a scale is bullt for measuring innovation strategies of companies in the p.c.e. Industry. The correlation matrix in table 5.11 pictures the relation between the five variables mentioned above. Correlations between these variables are generally low and hardly signiftcant.

Table 5.11: Correlation matrix of inmovation indicators.

\begin{tabular}{|c|c|c|c|c|c|c|}
\hline & RDINT & RDINTPCE & NEN PROD & REAL NP & BESTPRAC & INSTRAT1 \\
\hline $\begin{array}{l}\text { RDINT } \\
\text { RDINTPCE } \\
\text { WEN PROD } \\
\text { REAL NP } \\
\text { BESTPRAC } \\
\text { INSTRAT1 }\end{array}$ & $\begin{array}{l}1.0000 \\
.2301(*) \\
.2000 \\
.2316(*) \\
-.0907 \\
.3826 *\end{array}$ & $\begin{array}{l}.2301(*) \\
1.0000 \\
-.1096 \\
-.1107 \\
-.2048 \\
-.2677 \star\end{array}$ & $\begin{array}{c}.2000 \\
-.1096 \\
1.0000 \\
.4156 * \\
.3058 * \\
.8475^{*}\end{array}$ & $\begin{aligned} .2316(*) \\
-.1107 \\
.4156 * * \\
1.0000 \\
-.0373 \\
.7269 * *\end{aligned}$ & $\begin{array}{l}-.0907 \\
-.2048 \\
.3058 * \\
-.0373 \\
1.0000 \\
.4025 * \star\end{array}$ & $\begin{array}{l}.3826 * * \\
-.2677 * \\
.8475 * * \\
.7269 * * \\
.4025 * * \\
1.0000\end{array}$ \\
\hline
\end{tabular}

As the alm of the present analysis is to find one scale, the principal components analysis is applied for only one component. The weights of regression of the variables on the component, the so-called factor loadings, are given in table 5.12. 
Table 5.12: Factor matrix

Varlables:

Factor loadings of varlables on the component:

$\begin{array}{lr}\text { RDINT } & .38261 \\ \text { RDINTPCE } & -.26768 \\ \text { NEW PROD } & .84750 \\ \text { REAL NP } & .72685 \\ \text { BEST PRAC } & .40252\end{array}$

Varlance: 1.63

Proportion of explained vartance: .33

The coefficlent for RDINTPCE is apparently negative because a higher scorling on this indicator is in general related to lower scores on the other indicators, see also table 5.11. It can be concluded that the R\&D intensity in p.c.e. does not fit with the other indicators. The relatively low absolute value of the factor loading (.27) Indicates that thls varlable 1s less important to the scale for innovation strategles.

The position of elements, companies in this study, on the scale for Innovation strategles is fixed by so-called factor scores, 1.e. scores of elements on a component. By definition factor scores form a normal distribution with an average of zero and a standard deviation of one. Correlations between factor scores (INISTRAT 1) and the five varlables on which this scale is based are of course relatively high, see table 5.11. In Appendix 7 the scores of companies on five varlables and the original and classiffed factor scores are presented. The orlginal factor acores have been classiffed into innovation strategles (INSTRAT 2) as follows:

1: factor scores $<-.50$ imitative

2: $-.50 \leqslant$ factor scores $\leftarrow+.50=$ defensive

3: factor scores $>+.50$ offensive

Finaliy, these outcomes for innovation strategies can be set against the size of companies as in tables 5.13 and 5.14. From these tables and the tests of 1ndependence 1 it is evident that 
there is no or hardiy a sigalficant relation between size of companies and innovation strategles. Prom table 5.13 it is obvious that a substantial share of small and very large companies follow an offensive strategy, whlle almost all large and most medium sized compantes have a defenstve or imitative strategy.

Table 5.13: Innovation strategles versus slze of companles, number of compantes and $\%$.

\begin{tabular}{|c|c|c|c|c|c|}
\hline Strategles & Total & $\begin{array}{l}\text { Ov } \\
500\end{array}$ & $\begin{array}{c}11 \text { size } \\
500- \\
5,000\end{array}$ & $\begin{array}{l}5,000- \\
50,000\end{array}$ & $50,000+$ \\
\hline Initative & $\begin{array}{l}19 \\
33.9 \%\end{array}$ & $\begin{array}{c}4 \\
28.6 \%\end{array}$ & $\begin{array}{c}8 \\
42.1 \%\end{array}$ & $\begin{array}{c}5 \\
35.7 \%\end{array}$ & $\stackrel{2}{22.2 \%}$ \\
\hline Defensive & $\begin{array}{l}18 \\
32.1 \%\end{array}$ & $\begin{array}{l}2 \\
14.3 \%\end{array}$ & $\begin{array}{c}5 \\
26.3 \%\end{array}$ & $\begin{array}{l}8 \\
57.1 \%\end{array}$ & $\frac{3}{33.3 \%}$ \\
\hline Offensive & $\begin{array}{l}19 \\
33.9 \%\end{array}$ & $\begin{array}{c}8 \\
56.1 \%\end{array}$ & $\begin{array}{c}6 \\
31.6 \%\end{array}$ & $\begin{array}{l}1 \\
7.1 \%\end{array}$ & $\begin{array}{c}4 \\
44.4 \%\end{array}$ \\
\hline Tatal & $\begin{array}{c}56 \\
100 \%\end{array}$ & 10 & $\begin{array}{c}19 \\
100 \%\end{array}$ & $\begin{array}{c}14 \\
100 \%\end{array}$ & $\begin{array}{c}9 \\
100 \%\end{array}$ \\
\hline
\end{tabular}

$\begin{array}{ll}\text { ChI-Square } & : 10.69375 \\ \text { D.F. } & : 6 \\ \text { Signiftcance } & : .0983\end{array}$

In table 5.13 innovation strategies are assigned to three groups of companies which divide the total of companies into equal shares. If one assumes that it is more realistic that there are fewer companles with an offenstve strategy and larger number of compantes with a defensive strategy the plcture might change.

In tabel 5.14 se of companies is set agalnst Innovation strategles (see appendix 7, INSTRAT 3) after a re-classification of the original factor score as follows:

1: factor scores $<-.50$ = imitative

$2:-.50 \leqslant$ factor scores $\leqslant+1.00=$ defensive

3: factor scores $>+1.00$ of fensive

In that case there 1 s clearly no significant relation between size and Innovation strategy. Nevertheless, a certaln pattern becomes clear. Imitative strategies, with relatively small innovative 
efforts, are followed by a comparatively large share of medium sized and large companles. Few small and very large flrms appear to follow such a strategy. Defensive strategles, at some distance from radical Innovating companies, are in particular pursued by large and very large companies, Offenstve strategles can be attributed to a relatively large share of mall comanles and to some medium sized and very large companies but not to large compantes.

On the whole both small and very large companies in the p.c.e. industry follow a more innovative strategy than medium sized and large companies.

Table 5.14: Innovation strategles versus size of compan1es, number of companies and $\%$.

\begin{tabular}{lccccc}
\hline & Total & \multicolumn{3}{c}{ Overa11 s1ze } & s00- \\
Strategles & & 500 & 5,000 & 50,000 & $50,000+$ \\
\hline Imitative & 19 & 4 & 8 & 5 & 2 \\
Defensive & $33.9 \%$ & $28.6 \%$ & $42.1 \%$ & $35.7 \%$ & $22.2 \%$ \\
& 26 & 5 & 7 & 9 & 5 \\
Offensive & $46.4 \%$ & $35.7 \%$ & $36.8 \%$ & $64.3 \%$ & $55.6 \%$ \\
& 11 & 5 & 4 & - & 2 \\
\hline Total & $19.6 \%$ & $35.7 \%$ & $21.1 \%$ & & $22.2 \%$ \\
\hline & 56 & 14 & 19 & 14 & 9 \\
& $100 \%$ & $100 \%$ & $100 \%$ & $100 \%$ & $100 \%$ \\
\hline
\end{tabular}

Ch1-Square $\quad: 7.35537$

D.F. : 6

Significance : .2892

5.5 SOME CONCLUSIONS

The findings of the survey of the international p.c.e. Industry regarding the relation between size of companies and Inmovation do not unambiguously support any of the well-known hypotheses completely. The results vary to some degree depending on the applied 1ndicator of innovation. 
Nevertheless it $1 \mathrm{~s}$ stil possible to arrive at some conclusions for the Induatry:

- The findings for R\&D activitles support the general notion that the 1ndustry has become sclence based as nearly all compantes perform R\&D.

- Al1 mall compantes perform RaD. Surprlalngly, they concentrate, on average, wost of the fr RGD on basic and applied research and far less than other size categorles on product development. On average small companies are more research intensive than the other classes. They also reach a substantial shere of thelr curnover with new products. However, they do lag In the diffusion of best practice technology.

- On the other hand the group of the very large, multinational and diversifted, campanles as a whole appear most innovative. All the very large companies perform R\&D, the relative importance of RQD categorles is simflar to results found in ather studies. More than half of these companies have been able to generate a substential share of their turnover wh new products and they clearly lead in the introduction of best practice technologies.

- The other two size-classes take an intermediate position. Most of these companies, but not all of them, perform R\&D. Their postition regarding innovation changes depending on the indicator. Over $40 \%$ of the medium sized companies depend for a substantial share of their turnover on new products, for large compantes this goes only for about $20 \%$ of this size-class. On average both classes have been less successful with the introduction of best practice technology than the group of very large compantes.

- Innovation strategies of the large, multinational, companies reflect mejor lssues of technological development mentioned in the preceding chapter. In the p.c.e. Industry companies follow several Innovation strategles such as offensive, defensive and imitative. Other strategies are hardly relevant in this particular sector of Industry. Size of compantes ts not decisive for pursuing any of the three strategles mentioned above, but in particular many small and very large companies follow a more Innovative strategy, while few companies in these categories depend on an imftative strategy. 
- The distribution of innovative performance in this industry. wth both small and very large companies standing out as mafor groups of Innovating compantes, can be explalned by the technollogical and industrial changes in the past decades. The large-scale introduction of information technology and electronics led to a 'rejuvenation' of the technologlcally mature Instrument industry. World-leading companles in information technology entered the market and the largest Instrument conpanies diversified into electronics. Therefore, the group of very large, diversifled, multinational companies with thetr broad flelds of interest in infornation technology and microelectronics is a major source of innovation in the industry. On the other hand, a number of relatlvely small companies can benefit from well-known advantages attributed to this category of firms and play a substantial role in generating innovations. In other words, if creative destruction in an industry is characterized as a change from meturity tnto a new phase of advanced technological refuvenation, both small, R\&D intensive, and very large, diversifled, companies pay a disproportionate contribution to technological change in the industry. 
In this inal chapter I 111 sumarize the nain arguments developed and the conclusions which have exerged for the development of the theory of Imovation and Industrial change.

At the outset of this study two major objectives were formulated. One objective was to assess the contribution to innovation theory made by some heterodox theorles of economic and technological development. In particular those theoretical contributions are stressed In which disequilibrium effects of technological and dynamic changes within the economy are of particular relevance to this study. Both Harx and Schumpeter are accepted by many as early contributors to this fleld who stand out as having pald extensive attention to changes caused by technological development. In order to capture the value of their contributions I felt it necessary to return to the original texts and present my interpretation of both Marx"s and Schumpeter's theorles on many 1ssues which are still. the subject of debate and research in innovation theory and industrtal economics. This assessment has been quite critical of certain elements in both theorles while others were more appreciated. The review of these theories furthermore enabled me to pay attention to neo-Marxist and neo-Schumpeterian contributions which have taken the original arguments one step further. The review and interpretation of the relevant literature led to a synthesis of different approaches in a framework in which continuity and discontinulty of technological development, asymmetry of companies, the dynamic of technological development in relation to its environment and the tmportance of company strategles are stressed. The other major objective of this study was to develop the line of argument not only at the theoretical level but to demonstrate the viabllity of the approach in an emplrical analysis as well.

This euplrtcal analysis has been restricted to one sector of Industry which limits the posstbility of generalization as is the case in a multi-sector study. However, it also has a large number of advantages to research with an experimental design. The sector studied, the process control equipment (p.c.e.) Industry, is clearly at the intersection of several important econonic and 
technological developments. The study of this wlder context and interrelations provides the necessary information to the analysis of Inter-sectoral patterns of change which would be hidden in an isolated sector study. Also the emphasis on the internattonal settling of sectoral and technologlcal development has given this approach a wider signifficance. The emphasts on change in the structure of Industry found in many evolutlonary theories of Innovation is fully reflected in the present research. Technologlcal change has led to a relatively new sector whlch developed from the older measurement industry to an electronies and information technology related sector. There is a lack of offlctal statistics on this sector and empirlcal material had to be created through survey-research. To study effectively the consequences of technological change for the industry structure will necessarily lead to applied research on other materlal than offlelal statistics which have a time-lag of several years. As Schumeter already pointed out a large number of sector studies is restricted to offlctal statistics and as a result the emergence of new Industries and changes within branches is neglected. Too of ten economic studies are too independent on time-serles from archatc Industrial classifications. The analysis in the previous chapters is a contribution to the understanding of new and 'hldden' sectors of Industry which are not ldentified in officlal statistics and therefore generally disregarded in industrial economlcs. The somewhat experfmental character of the study is partly shown in the empirical research in the survey of companies, an approach to research, which is generally accepted in many other soctal sclences, but a Httle neglected in industrial economics.

Another argument in favour of a sector study relates to the experimental character of the theoretical and conceptual dealgn of this etudy. The viabl11ty of a set of anelytical tools and Indlcators of Innovation, different from the famlllar ones, which are not based on concepts such as technolog1cal trajectortes and dynamic diffusion, can be tested tentatively for a group of companies and relevant technologtes first. The argument in favour of the need for more 1n-depth study of technological development itself limits the range of technologies to be consldered in a study but it provides information which could not be analyzed otherwise. 
For the further development of a critical evolutionary theory of Industrlal development 1 t 11 be helpful to understand the relationship between technologlcal development and a selection environment as a dialectical relationship in which both elements Influence each other. In that sense this dialectical relationship 1s Identical to the forces of production and production relations In Marx" theory. The selection environment in terms of production relations affects not only soclal relations in a wder perspective but also the setting of different competing companies. Marx's attempt to understand technological development 1 tself and to anaIyze 1t as an endogenous factor is st111 most relevant to modern innovation theory. The shortconings in his theory in over-emphasizing process Innovations and bullding a crisis theory on a onesided interpretation of the effects of mechanization cannot prevent us from recognizing the sclentific benefits from any serious and in-depth understanding of technological development. Contrary to Marx, Schumpeter paid less attention to technological. development 1tself. In his early writings technology is both endogenous and exogenous. Invention 1 s discussed as an exogenous factor and innovation is partly endogenous in its contribution to the growth of (new) companies in pre-trustified capltalism. In Schumpeter's theory of modern capitalism invention and innovation become endogenous 1 in the innovative role of large, sclence based, companies. For present attempts to develop a theory of Innovation, Schumpeter's definttion in elther new production functions or new combinations 15 only of limited value as he took both technical and organizational innovation into his definition. Although technical and organizational aspects of Innovation are definitely related it appears more useful to distinguish between them analyt1cally. Another necessary Improvement on Schumpeter's theory is to emphasize the role minor technological Improvements play once more or less radical Innovations have been introduced. Th1s particular feature has been stressed throughout this study in the emphasis on understanding technological development as a process of Innovation and diffuston in which technological trajectorles play an important role. 
An effort has been made to provide analytical tools to understanding technological development as a process of evoluttonary and dynamic change. Following Marx, the interaction of sclence and technology has to be stressed as an fmportant feature of present day capitalism. However, this does not imply that despite interaction both technology and sctence do not have their own autonomous momentum. Technology can be distinguished from both scfence and craft as a different realm of technical change. It is more applied and practical than science and more theoretically mediated than craft which is mainly based on trial and error and tradition. In Industries which can be characterized as sclence-based or "high tech" the interaction of applied sclentific research and technology becomes more intensified. In the p.c.e. Industry this intensiflcation is found in the RaD intensity and the present research agenda which disclosed advanced research at the technological and scientific frontier of a broad spectrum of sub-disciplines in information technology.

To understand the heurlstics in particular fields of technology and Industrial sectors it will be necessary to further develop a theoretical and conceptual framework which goes beyond orthodox economic theory. It also has to go beyond the Marxist notion of forces of production which is too abstract. In some recent contributions serfous attempts have been made to broaden the scope of economics with an analytical framework including notions such as technologlcal paradigms, basic designs, technologlcal trajectories and technological frontier. These notions are well-suited to Impressionistic pictures of general developments without too much care for detail. However, It is posslble to 'tighten' an analytical framework with such notions in distingulshing levels of abstraction, providing clear definitions and demonstrating the coherence of $1 \mathrm{t}$. In the preaent study the relevance and advantages of such an analytical framework has been demonstrated in more concrete operational constructs and emplrical research.

Analyzing technologlcal change as a change from or within technological paradigm analogous to Kuhn's sclentific paradigm is a subject to be developed more extensively within other disciplines 
auch as technology dynamics and soctology of technology. Theoretleal developments in these disciplines can be integrated into the economics of technological change. In the present study technologlcal paradigms have been analyzed as a first approximation of the identification of technological opportunities in relevant induster.

The concept of technological paradigms has been used to analyze changes in process technologies and Information technology which have become Interlocked in process control technology. On the 'denand side' af process control chemical, Iron and steel, and food processing, as major flelds of process technology, depend to a large extent on further development of advanced process control. For both developments whith present dominant paradigms and the emergence of new paradigms in process industrles advanced process control 1 s essential. In its turn sophisticated process control is partly dependent on technological input from information technology, and in particular computers, software, microelectronics and (tele-) communications. The introduction of computers led to more advanced p.c.e. and a shift of paradigm from pre to post computer guided control. Technological complexity of present control technology is caused by the interaction of process technologies and Information technology.

The Interplay of several paradigms is characteristic for the complexity of modern technology. Changes of paradigms effect the opportunitles of compantes operating withln an industry and a field of technology. Changes within technological paradigms, whether caused by companiles or other institutions from the technologlcal Infrastructure, w11 influence the competitlve (dis)advantages of particular companles. However, changes of paradigms have a further reaching ffect because they go beyond existing routines and heurlstics. In that case $1 \mathrm{t}$ can be expected that the asymetry of compantes operating in an Industry is enlarged and, moreover, new companies and cross-entries famlliar with basic heuristics in the new paradigm will change the structure of the Industry. Sowe of the financlally better equipped companies will be able to find sophlsticated take-over partners or merge with other companies. Whth the emergence and gradually growing fmpact of a new paradigm disorder of industry structure is even more apparent than in the case of gradual changes within a technological paradigm. 
For further emplrical research the notion of bastc design is more sulted because $1 t$ can be interpreted as a materlal "precipltate" from one or more paradigms. Technological development of basle deslgns can be measured in the technological performance of $1 \mathrm{ts}$ characteristlcs. In the early stages of a new paradigm there w111 be a branching pattern of developing basic designs. In the process of maturation of a paradigm there will be more clarity as to the direction of technological change and gradually fewer bastc designs w11 be found. The selection of technological options is mediated by the selection environment in terms of the strategles of competing companies at the supply and demand slde. In an oligopolistic structure a relatively small number of basic designs developed by leading companies can be expected to set standards for the industry. In an ollgopsonic structure cholces made by a few leading companies are declisive to the further development of bastc designs. With a change of technological paradigm the existIng Industry structure becomes more destabllized than in case of a routinized paradigmatic development.

In the process control industry the change of paradigm in the early sixtles led to a phase of experimentation with different applications of computer control and programmable controllers. Several forms of computer control were developed until modern distributed and Integrated control became the new standards. Meanwhile the structure of both supply and demand had changed. Technological development in major process 1ndustrles such as from and steel processing and chemicals led to a more complex industrial processing with a need for more sophlstlcated control. This demand for advanced control was met by the experiments with computer contral in which some large users played a declsive role. The change of paradigm in process control is partly demonstrated with the entry of electronfcs compantes and take-overs of small information technology compantes by larger p.c.e. compantes. It also led to a differentiation of suppliers Into suppliers of complete oystems, manufacturers of sophisticated stand-alone equipment and producers of simple devices and 'older" equipment. Although there were a 
number of competing basic deslgns the preference for a distrlbuted system was apparent in many large users of process control systews. Technological development in information technology, in particular the introduction of micro-computers, enabled the emergence of this new baslc design ploneered by Honeywell and a small number of other companies.

Although the analysis at the level of basic destgns has galned in concrete understanding of both more radtcal and gradual technological changes $1 t$ will in many instances be necessary to further Alaggregate the analysis of concrete technological developments. In particular if complex technological systems are studied in relation to the role different suppliers play, it might be compulgory to analyze the development of so-called key-elements. These key-elements are essential components of a technological system. In this study the system of process control is examined from bottom-up, from sensors to contrallers, programmable controllers, process control systems to production control systems, Including both hard- and software.

To understand the direction of technological development in basic deslgns or key-elements, to discover the heuristics and routes of problem solving, it will be necessary to identify set of characteristics and the gradual improvements along these characteristlca. In such a procedure one can sellect generations of a keyelement in order to operationalize the concept of technological trafectorfes. For each key-element generations are related to older, average practice and best practlce technology, as well as to the technolog1cal frontier. The complete exercise provides a detalled and overali view of technological developrent in a complex sytem. Through the disaggregation of a baslc degign and the operationalization of technologlcal trajectorles it becomes feaslble to measure the technological performance of companies at the level of technological sophistication of thelr supply of components and/or systems. In other words, it $1 \mathrm{~s}$ possible to anelyze the position of compantes vis a vis the range of keyelements In a baste design and the technological trajectorles thereof. 
In this study it has been stressed several times the technologfical development is not only a matter of forward moving frontlers of best practice technologies, but also the fnteraction of best practice technologies with diffusion which give technological development its full economic impact. In the process of diffusion technology affects a wider group of users and suppliers goling beyond the effects on the original innovator/adopter. In the relationship between technology and diffusion the dynamic and evolutionary character of both economic and technological development becomes most clear. In the traditional theories of diffusion its pattern is usually deplcted as an S-shaped curve. Some criticism has been concentrated on doubts regarding the regularity of the S-curve with different slopes and different points of inflection in concrete patterns of diffusion. More fundamental criticism stems from the lack of dynamics in traditional theories of diffusion. In traditional theory dynamics is only reflected in the gradual growth of the number of adopters of which the maximum of potential adopters is given. In a more dynamic and evolutionary approach two important features are stressed:

- there is a change in the number of potentlal adopters during the process of diffusion, while there is not given limit to the potential number of adopters;

- the technology itself changes during the process of diffusion. Changes in technology can, In retrospect, be related to technological trajectories in terms of the previously mentioned generations. The analysts of the rate of diffusion measured as diffusion of generations provides knowledge about trends 1 in diffusion admitting for dynamic changes within the process of diffusion. In most studies diffusion is measured at elther the Intra-firm, Intra-sectoral, or inter-sectoral level. The output with a particular technology or the number of compantes applying a technology is usually taken to measure the rate of diffusion. In this study the average intra-sectoral rate of diffurion has been applled with a differentiation for several categories of companies. One of the results of this approach is detalled information on the diffusion of Information technology, the principal determinant of technological trajectories in process control, at key-element level for the complete system of process and production control. 
As the technologleal frontler is operationalized as the direction of applled research for the near-future generations it is also possible to asess particlpation of compantes at the technological front Ler.

\section{Technologlcal change and 1 ts selection environment}

It has to be stressed that technologlcal development is nelther an autonomous nor a deterministic process. There is a dialectical relationshtp between technologlcal development and its selection environment in which there is mutual influence. For some technologles the selection environment is dominated by other social relations than just companies as e.g. state agencies and capitallabour relations constitute the selection environment. For many technologies the selection environment is formed by companies and consumers within a state regulated context. In capital goods producing sectors, such as the p.c.e. Industry, the selection env1romment consists malnly of producers on the supply and procuring compantes on the demand side. However, state regulation, e.g. In setting standards for pollution control, has an effect on the number of control variables and the complexity of control systems. Another useful analytical distinction to be made refers to the ex ante and ex post selection environment which do, however, interact. Ex post selection mechanisms influence economic, and eventually also technological, results and opportunities of companies. Competition between suppliers acts as a selection mechanism, but demand 1 is probably Just as important as 1 t sets the limts to growth for a sector. Demand by a differentiated set of buyers can articulate particular technological and economic specifications. In process control there has been a growth of the sector and many of $1 \mathrm{ts}$ compantes with the Increase in finvestment in control in process industries in the flrst decades following the aecond world war. Since the seventles excess capacity in many user-findustries has caused a stagnation in the volume of demand for p.c.e. However, the qualitative change in demand for more sophlsticated equipnent together with a stagnation of aggregate demand has Induced strong competition, in particular for more advanced systems and stand-alone equipment. 
The ex ante selection environment is determined by the behavlour of companies in their strategies, routines and search procedures for Innovation. Behaviour of companles differ because there is an asymetry in the configuration of companies. This asymetry was already expressed in the theorles by Marx and Schumpeter. Marx built his theory on the uneven development of companles in the process of centralization and concentration which caused and disequllibrium effects in the economic structure. Both Marx and Schumpeter saw the innovation generating process as a powerful mechanism for growth of individual companies which were able to capture incidental extra-profits. They both pald attention to the role of small compantes as innovators, although not to the same extent. Schumpeter stressed the role of the entrepreneur as the personffication of innovation in so-called pre-trustified cap 1talism. Marx saw the importance of new companies as innovative, example setting, front runners. There $1 \mathrm{~s}$ evidence that Marx and Schumpeter neglected a more subtle differentiation of companies and over-emphasized the dominance of large compantes in modern capitalism. Nevertheless, the dynamic elements in their theories are valuable to the understanding of present day capitalism. This holds in particular for schumpeter's understanding of market power and monopoly as short-run monopoly based on Innovation which, due the creative destruction and competition, is far from structural monopoly.

Some trafts of static elements in Marx"s and Schumpeter's theories have been accentuated in neo-Marxist theories of monopoly capttalIsm and Schumpeter-Insplred theorles such as in Galbralth. There are differences between such heterodox theorles of capltallsm but grosso modo they picture technological development as being dom1nated by very large compantes. As such there is hardly any role for other categorles of companles while the effects of creative destruction are neglected. Contrary to Marx"s and Schumpeter' orlginal contribution, monopoly has become size-dependent in many neo-Marxist and Schumpeter inspired theories. In some ather neoSchumpeterian theories the importance of small and new companies as Innovators is stressed as in Schumpeter's earlier contributions. 
The debate so far has led to a serles of hypotheses and explanatlons of the relationship between size and innovation. An interestlng perspective for empirical research 1 s found in the introduction of technological opportunity as an intervening factor explaining inter-sectoral differences. Another way-out of the existing stale-mate is to pay more attention to a differentiation Into categorles of companies and Innovation strategles. In this study I arrived at a categorlzation of companies such as small and medium sized compantes, new compantes, subcontractors, large companles and very large multidivisionsl companies. Also crossentrles can be an lmportant category of flrms to understanding changes in the Industry structure and technological performance.

In the international p.c.e. Industry some categories of companies do not or have ceased to play a relevant role in the Industry as 1nnavator. The role subcontractors can be 1 gnored and new companies, often discussed in the debate on Innovation, probably played only germane role with the energence of the new paradigm in process contro1 three decades ago.

In the andyais of the Innovative performance of companies in the p.c.e. Industry different categarles of companies in terms of size, measured in numbers of employees, were dertved from the actual distribution in the international 1ndustry. The analysis of size as a relative instead of an absolute category is an important feature of this study. It seems almost trivial to point at the differences in relevant size-categorles for different industries and International markets: $\mathrm{e}$. the size of a large company in the Dutch furniture industry is almost negliglble compared to the dize of medium-stized company in the international chemical industry. Nevertheless, many studies and statements about the relationship between ize and Innovation neglect the inter-sectoral, Internatonal and technologlcal context of this 1sgue.

\section{Indicators of Innovative performance}

Some of the confusion In the Innovation debate is caused by the cholce of Indicators which can have strong effect on the assessment of Innovative performance of companies. In many economic studies of technological development the subject is studied with 
some poor Indicators of inmovation. No attention Is pald to technological development itself, which, as a consequence, usually remains a "black box". In this study both innovation input indicators such as RAD Intensity and the distribution of research categorles and output indlcators such as the share of new products in company turnover and the diffusion of best practice technologies have been applied. Innovation imput is to a large degree determined by comitments in the ex ante selection by compantes. Innovation outputs results from both ex ante and ex post selection mechantsms, $1 . e$. the supply of new products and best practice technology w11 result from deltberate company strategles but the distribution of the outcome of turnover and diffusion is also determined by competition and demand.

The results for different indicators do not generate a clear pattern for silze and Innovation. Some of the results give some support to the literature in which a U-form distribution $1 /$ proclaimed. Small companies are most ROD Intensive but the degree of variation indicates that there are both 'normal' and 'high tech' small compantes. The variation between and within results for different indicators supports the idea that the group of small compantes is quite diverse in 1 ts innovative performance. On the other end of the spectrum the group of very large compantes $1 \mathrm{~s}$ most innovative in particular in terms of new products. Medium sized and large compantes take an intermedlate position. In other words, from the results of this international sector study there Is little reason to support theorles in which small companies are seen as the major Innovative agents in capltallsm, in particular because they lag in the diffuston of best practice technologies. But there is also little evidence that innovation and technologleal development in de p.c.e. Industry is totally dominated by 'monopoly capital' or a small number of very large compantes. As mentioned in chapter 5 the importance of both amall and very large companies, which appear most Innovative In thls industry, can be explained by the technological revival into an electrontes related sector in which both very large diversifled companies and a group of amal1 RAD intensive companies are important Innovators: 
If It 1s accepted that industries are "structured" by perturbat1on, then disorder 1 s generated by different Innovation strateBles of several categories of companles. There are a number of strategies of which three, notably offensive, defensive and imitative, can in princlple be followed by all companies in this particular industry. This might seem to contradict the assumed asymetry of companies because it cannot be expected that a small company can behave as if it were very large diversifled mult1natlonal company covering a large number of markets. Larger companles can follow different atrategles for their diversified Interests. Small companies are by definition restricted to a small number of (sub-) markets and strategles. However, in one sector it is feasible to relate all companies to their Innovative strategy In that particular sector. For large companies it is possible to deduce the main toplcs in their strategies from publicly avallable information and interviews with management. In the p.c.e. Industry, for instance, It is relatively simple to picture innovation strategles of the leading compantes at the technological (or sclentific) frontier of applications and development of information technology. For the analysis of the Industry as a whole one has ta rely on several indicators of Innovation in a multivariate analysis. The complexity of the relationship between innovation and stze of compantes is reflected in the Impossibility to relate particular lnnovation strategles exclusively to classes of size of compantes.

So, even for an industry for which the technological opportuntty for compantes is grosso modo identical, it ls difficult to arrive at some generallizations. Given the state-of-the-art in the analysis of technological and Industrtal development it w11, however, not be necessary to find stralghtforward and unambiguous relations. In my opinion at least a part of the present research agenda should be directed towards developing analytical tools and more in-depth understanding of phenomena assoclated with economic and technological development. This field of research 19 well sutted for mult 1-and Interdsciplinary research with contributlons from soclal sclences and e.g. engineerting. Taken the complexity of disciplines one cannot expect an interdisciplinary and 
hollstic approach with an integrated body of knowledge. But even a moderate attempt to generate knowledge applicable in a more multidisclplinary approach to the understanding of technological development will have to go beyond accepted rowtines. It is in this perspective that in this study an attempt has been made to make a modest contribution to be field of technology and economics.

\section{Consequences for Innovation policles}

Technological development follows a difuse pattern with many differences as far as industry structures, size of companies, International comparisons, and company behaviour are concerned. There is little reason to suspect that general theorles and laws w11 bring about new insights within the near future. But while it does not necessarily lead to a pesilinistic view of the practical relevance of economic theary and research, $1 t$ does lead to a modest and middle-range theory orlented approach. If there 1 s no general pattern of technological development then most attention should be pald to analyzing inter-sectoral patterns, differences In company behaviour and differences in techmological opportunit1es. Such a differentiated approach will not render general policy options and measures. Innovation policy can not consist of mainly general policy instruments which have a positive effect on the Innovative potential of al1 companies. There 1 s no panacea, or to quote an American commercial for a fitness centre: "If it came in a bottle, everybody would have $1 t^{\prime \prime}$. In other words, stimulating Innovation can never be successful by just providing financlal support to all companies which claim to perform ome Innovative activity. Some companies w111 never be capable of becoming Innovative while for many others lnnovative performance will not depend on financial support. In some countrles the opportunities for companies in certain sectors w11 remain dim for many decades to come. For national states it w1ll only be possible to develop innovation and innovative policles if particular circumstances in a large number of industries 18 taken into account. In a large number of sectors it w11 be necessary to investigate the composition of a sector in terms of the national or international character of 
the companies, the international trends agalnst which national sector developments 111 have to be judged, the technological opportundties, the distribution of companies according to relevant categorles and the mafor national and international strategies of leading companies. The character of technological development has to be assersed becaluse it ia not only innovation but also diffuBion of relevant technologles which is important to understanding the opportunities of a particular industry. In such a differentiated approach policy instruments are derived from the analysis of technological opportunttles in a number of industries. Such analyses could benefit from some of the tools developed in this study. Improving technological performance of companies in some industries wil rely heavily on the diffusion of modern technologies, for others the costs of RGD or the improvement of the technologlcal infrastructure will be more relevant.

The complexity of modern technology with the interaction of different technological paradigms, the asymetry of companies and International perspectives, and rapld changes in technological opportunlties, can only be an abject of useful state intervention and public debate, if the pattern of its development is revealed in extenso. 
APPENDIX 1

THE SURVEY OF THE P.C.E. INDUSTRY

The p.ce industry is not directly related to a class or sub-class of a census of production or a standard trade clasalfication due to the fact that this sector is gradually evolving from both the instruments and electronics industry. In order to study the Industry it was necessary to go beyond offictal statiotical material and perform a survey research amongst p.c.e. manufacturers. Also the present conceptual framework for understanding technological developments in terms of basic designs, key-elements, and trajectorles, made it necessary to construct appropriate empirical data through survey research.

A provistonal 11 st of posstble p.c.e. manufacturers was estabI1shed by compiling information of all companies known through different sources of Information such as: expert interviews, manuals and trade directorfes. The following criterla were introduced to define the survey-population:

- In order to be able to communtcate with companies on a large number of subjects wthin a reasonable time-horizon it was necessary to select only those which have established a place of business in the Netherlands;

- several business units or subsidiarles of one company were taken together as one entry, in other words: In the survey the company is the accounting unit, which may encompass wore than one firm;

- since the population should exist of manufacturing companies, compantes which serve solely as dealers were neglected; manufacturing, however, may take place in the Netherlands and/or in any other country;

- a minimum annual turnover for p.c.e. of about us $\$ 400.000$ in 1985 was set because the 1ssues to be discussed in the burvey dealt with several technological and business aspects of p.c.e. which made a mintmum size compulsory. 
These four criterla led to a reduction of the list of possible p.c.e. manufacturers to 81 companles. Unfortunately, only 56 compantes agreed to participate in our survey research. In that sense this research is effected by the present upheaval in emplr1 cal research on innovation-related subjects to which many companies refer as 'survey- or Interview mala'.

It 18 important to note that the population of p.c.e. manufacturers in this study is not a sample as such. Given the limitations mentioned in the four criterla above and given the response of the group of manufacturers this population presents a fair reflection of the international industry structure. It is assumed that the international industry structure is well represented in this survey because:

- $80 \%$ of the leading compantes mentioned in table 5.1 participated in the survey;

- the market for p.c.e. companies operating in the Netherlands is extremely open, most process Industries in the Netherlands are internationally orfented, $e . g$. mast of the leading chemical companies and engineering contractors are found in the Netherlands.

Unless otherwise indicated the information from the survey refers to 1985 .

The interviews and first information processing during the survey were carrled out by SKIM MC.MA, Rotterdam. 
APPENDIX 2

Distribution of value of production of generations of sensors $1 \mathrm{n}$ and coefflclents of variation for 1985 and (1980), and number and \% of companies with research at the technological frontler of sensors, $N=35$.

\begin{tabular}{|c|c|c|c|c|c|}
\hline & Total & 500 & $\begin{array}{c}\text { Overal1 } \\
500- \\
5000\end{array}$ & $\begin{array}{l}\text { s1ze } \\
5000- \\
50000\end{array}$ & $50000+$ \\
\hline \multicolumn{6}{|l|}{ Pneumatic: } \\
\hline average $\%$ & $\begin{array}{c}16 \\
(24)\end{array}$ & $\begin{array}{c}17 \\
(23)\end{array}$ & $\begin{array}{c}17 \\
(25)\end{array}$ & $\begin{array}{c}12 \\
(20)\end{array}$ & $\begin{array}{c}21 \\
(32)\end{array}$ \\
\hline$c v$ & $\begin{array}{c}1.6 \\
(1.4)\end{array}$ & $\begin{array}{c}1.7 \\
(1.7)\end{array}$ & $\begin{array}{c}1.5 \\
(1.4)\end{array}$ & $\begin{array}{c}1.3 \\
(1.4)\end{array}$ & $\begin{array}{c}1.9 \\
(1.4)\end{array}$ \\
\hline
\end{tabular}

Electronic:

$\begin{array}{lccccc}\text { average \% } & 78 & 83 & 79 & 80 & 70 \\ & (75) & (77) & (74) & (80) & (66) \\ & & & & & \\ \mathrm{cv} & 0.3 & 0.3 & 0.3 & 0.3 & 0.5 \\ (0.4) & (0.5) & (0.5) & (0.3) & (0.7)\end{array}$

Smart sensors:

\begin{tabular}{lccccc} 
average & 6 & - & 4 & 8 & 9 \\
cv & $(1)$ & $(-)$ & $(1)$ & $(-)$ & $(2)$ \\
\hline Totel \% & 1.7 & - & 2.3 & 1.5 & 1.3 \\
& $(3.0)$ & $(-)$ & $(3.0)$ & $(-)$ & $(2.0)$ \\
\hline $\begin{array}{l}\text { Companleg w1th } \\
\text { research at } \\
\text { technological } \\
\text { frontler }\end{array}$ & 100 & 100 & 100 & 100 & 100 \\
& $(100)$ & $(100)$ & $(100)$ & $(100)$ & $(100)$ \\
no research & 29 & - & 11 & 11 & 7 \\
& $83 \%$ & - & $79 \%$ & $100 \%$ & $100 \%$ \\
Total & & & & & \\
& $17 \%$ & $100 \%$ & $21 \%$ & - & - \\
\hline
\end{tabular}


A.PFESDIX 3

Distribution of value of production of generations of hardwired (1ogic) controller in $\%$ and coefflclents of varlation for 1985 and (1980), and number and $\%$ of companies with research at the technological frontier, $N=37$.

\begin{tabular}{|c|c|c|c|c|c|}
\hline & Total & 500 & $\begin{array}{c}\text { Overa11 } \\
500- \\
5000\end{array}$ & $\begin{array}{l}\text { eize } \\
5000- \\
50000\end{array}$ & $50000+$ \\
\hline \multicolumn{6}{|l|}{ Pneumatic: } \\
\hline average $\%$ & $\begin{array}{c}10 \\
(15)\end{array}$ & $\begin{array}{c}4^{4} \\
(10)\end{array}$ & $\stackrel{5}{(11)}$ & $\begin{array}{c}14 \\
(19)\end{array}$ & $\begin{array}{c}17 \\
(20)\end{array}$ \\
\hline $\mathrm{cv}$ & $\begin{array}{c}2.1 \\
(1.8)\end{array}$ & $\begin{array}{c}2.8 \\
(2.6)\end{array}$ & $\begin{array}{c}2.2 \\
(1.6)\end{array}$ & $\begin{array}{c}1.3 \\
(1.1)\end{array}$ & $\begin{array}{c}2.4 \\
(2.2)\end{array}$ \\
\hline
\end{tabular}

Electronle:

$\begin{array}{lccccc}\text { average } & 68 & 74 & 39 & 80 & 79 \\ & (65) & (65) & (52) & (70) & (78) \\ \text { cv } & 0.5 & 0.5 & 0.9 & 0.3 & 0.5 \\ & (0.6) & (0.7) & (0.6) & (0.5) & (0.6)\end{array}$

Smart sensors:

\begin{tabular}{lccccc} 
average \% & 22 & 22 & 56 & 6 & 4 \\
cv & $(20)$ & $(25)$ & $(37)$ & $(11)$ & $(2)$ \\
\hline Total \% & 1.4 & 1.6 & 0.6 & 1.5 & 2.0 \\
& $(1.8)$ & $(1.7)$ & $(1.0)$ & $(2.7)$ & $(1.5)$ \\
\hline $\begin{array}{l}\text { Compantes w1th } \\
\text { research at } \\
\text { technologtcal } \\
\text { front 1er }\end{array}$ & 100 & 100 & 100 & 100 & 100 \\
& 25 & $(100)$ & $(100)$ & $(100)$ & $(100)$ \\
no resea rch & $68 \%$ & $29 \%$ & $82 \%$ & $82 \%$ & $63 \%$ \\
\hline & 12 & & & & 5 \\
Total & $32 \%$ & $71 \%$ & $18 \%$ & $18 \%$ & $38 \%$ \\
\hline
\end{tabular}


Distribution of value of production of generations of PLC"s in and coefficlents of varlation for 1985 and (1980), and number and \% of companies with research at the technological frontler, $N=19$.

\begin{tabular}{|c|c|c|c|c|c|}
\hline & Total & 500 & $\begin{array}{c}\text { Overa } 11 \\
500- \\
5000\end{array}$ & $\begin{array}{l}\text { slize } \\
5000- \\
50000\end{array}$ & $50000+$ \\
\hline \multicolumn{6}{|c|}{$\begin{array}{l}\text { Upto } 100 \text { programm steps, } \\
\text { no data processing: }\end{array}$} \\
\hline average $\%$ & $\begin{array}{c}21 \\
(27)\end{array}$ & $\begin{array}{l}10 \\
(25)\end{array}$ & $\overline{(-)}$ & $\begin{array}{c}45 \\
(50)\end{array}$ & $\begin{array}{l}18 \\
(20)\end{array}$ \\
\hline $\mathrm{cv}$ & $\begin{array}{c}1.8 \\
(1.6)\end{array}$ & $\begin{array}{c}1.4 \\
(1.4)\end{array}$ & $(-)$ & $\begin{array}{c}1.2 \\
(1.1)\end{array}$ & $\begin{array}{c}2.2 \\
(2.2)\end{array}$ \\
\hline
\end{tabular}

Upto 1000 programm steps, restricted data processing:

$\begin{array}{lccccc}\text { average } \% & 41 & 55 & 97 & 10 & 29 \\ & (27) & (12) & (95) & (7) & (22) \\ \text { cv } & 0.9 & 0.1 & 0.1 & 1.2 & 1.1 \\ & (1.4) & (1.4) & (0.1) & (2.1) & (1.5)\end{array}$

Over 1000 programm steps and data processing:

\begin{tabular}{|c|c|c|c|c|c|}
\hline average & $\begin{array}{c}38 \\
(46)\end{array}$ & $\begin{array}{c}35 \\
(63)\end{array}$ & $\begin{array}{c}3 \\
(5)\end{array}$ & $\begin{array}{c}45 \\
(43)\end{array}$ & $\begin{array}{c}53 \\
(58)\end{array}$ \\
\hline $\mathrm{cv}$ & $\begin{array}{c}1.0 \\
(1.0)\end{array}$ & $\begin{array}{c}0.6 \\
(0.8)\end{array}$ & $\begin{array}{c}2.0 \\
(1.4)\end{array}$ & $\begin{array}{r}1.2 \\
(1.2)\end{array}$ & $\begin{array}{c}0.8 \\
(0.8)\end{array}$ \\
\hline Total \% & $\begin{array}{c}100 \\
(100)\end{array}$ & $\begin{array}{c}100 \\
(100)\end{array}$ & $\begin{array}{c}100 \\
(100)\end{array}$ & $\begin{array}{c}100 \\
(100)\end{array}$ & $\begin{array}{c}100 \\
(100)\end{array}$ \\
\hline $\begin{array}{l}\text { Companfes with } \\
\text { research at } \\
\text { technolog ical } \\
\text { frontier }\end{array}$ & $\begin{array}{l}15 \\
79 \%\end{array}$ & $\begin{array}{c}2 \\
50 \%\end{array}$ & $\begin{array}{l}2 \\
67 \%\end{array}$ & $\begin{array}{c}5 \\
83 \%\end{array}$ & $\begin{array}{c}6 \\
100 \%\end{array}$ \\
\hline no research & $\begin{array}{c}4 \\
21 \%\end{array}$ & $\begin{array}{c}2 \\
50 \%\end{array}$ & $\frac{1}{33 \%}$ & $\frac{1}{17 \%}$ & - \\
\hline Total & $\begin{array}{c}19 \\
1.00 \%\end{array}$ & $100 \%$ & $\begin{array}{c}3 \\
100 \%\end{array}$ & $\begin{array}{c}6 \\
100 \%\end{array}$ & $\begin{array}{c}6 \\
100 \%\end{array}$ \\
\hline
\end{tabular}


Distribution of value of production of process control systems in $\%$ and coeffictents of variation for 1985 and (1980), and number and $\%$ of companies with research at the technological frontier, $v=40$.

\begin{tabular}{|c|c|c|c|c|c|}
\hline & Total & 500 & $\begin{array}{c}\text { Overa11 } \\
500- \\
5000\end{array}$ & $\begin{array}{l}\text { size } \\
5000- \\
50000\end{array}$ & $50000+$ \\
\hline \multicolumn{6}{|c|}{ Centralized: } \\
\hline average \% & $\begin{array}{c}18 \\
(22)\end{array}$ & $\begin{array}{c}43 \\
(29)\end{array}$ & $\begin{array}{c}19 \\
(23)\end{array}$ & $\begin{array}{c}9 \\
(29)\end{array}$ & $\begin{array}{c}6 \\
(7)\end{array}$ \\
\hline $\mathrm{cv}$ & $\begin{array}{c}1.5 \\
(1.5)\end{array}$ & $\begin{array}{c}1.6 \\
(1.6)\end{array}$ & $\begin{array}{c}1.4 \\
(1.3)\end{array}$ & $\begin{array}{c}1.4 \\
(1.4)\end{array}$ & $\begin{array}{c}1.3 \\
(1.6)\end{array}$ \\
\hline \multicolumn{6}{|c|}{ Distributed, analogous: } \\
\hline average $\%$ & $\begin{array}{c}29 \\
(34)\end{array}$ & $\begin{array}{c}26 \\
(37)\end{array}$ & $\begin{array}{c}29 \\
(36)\end{array}$ & $\begin{array}{c}31 \\
(36)\end{array}$ & $\begin{array}{c}28 \\
(28)\end{array}$ \\
\hline $\mathrm{cv}$ & $\begin{array}{c}0.9 \\
(1.1)\end{array}$ & $\begin{array}{c}1.2 \\
(0.9)\end{array}$ & $\begin{array}{c}1.0 \\
(0.9)\end{array}$ & $\begin{array}{c}0.7 \\
(0.9)\end{array}$ & $\begin{array}{c}1.1 \\
(1.1)\end{array}$ \\
\hline
\end{tabular}

Smart sensors:

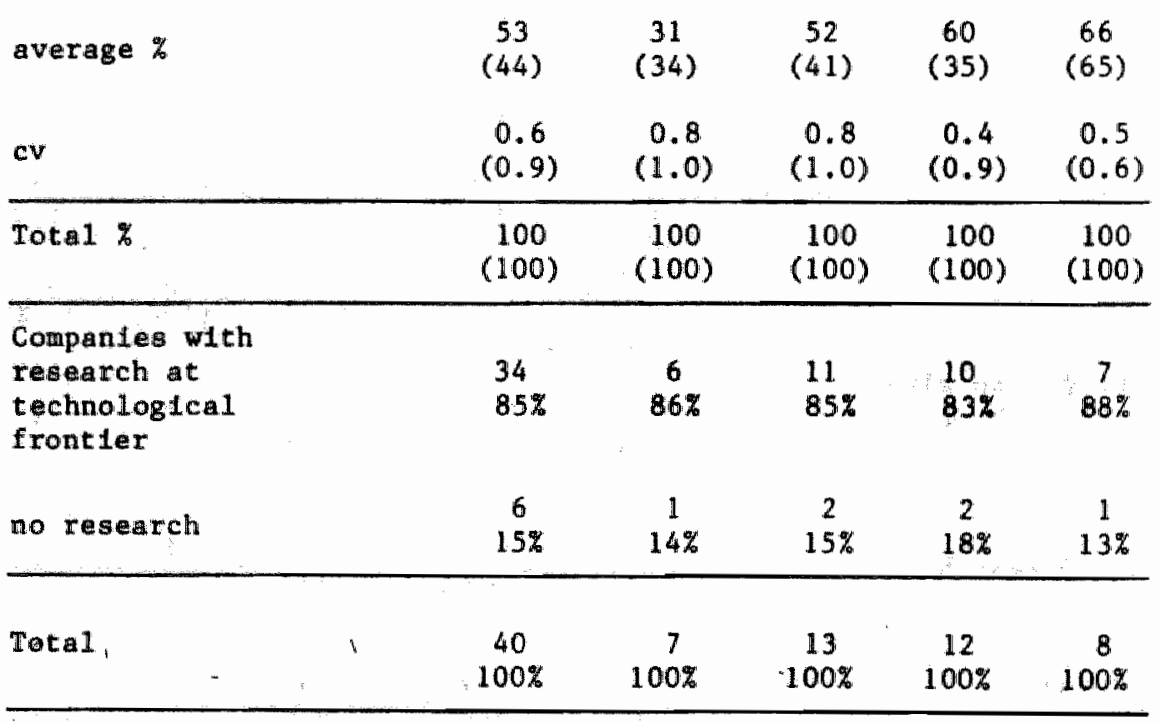


INDICATORS OF BEST PRACTICE TECHNOLOGY SUPPLIED BY P.C.E. MANUFACTURERS IN 1985.

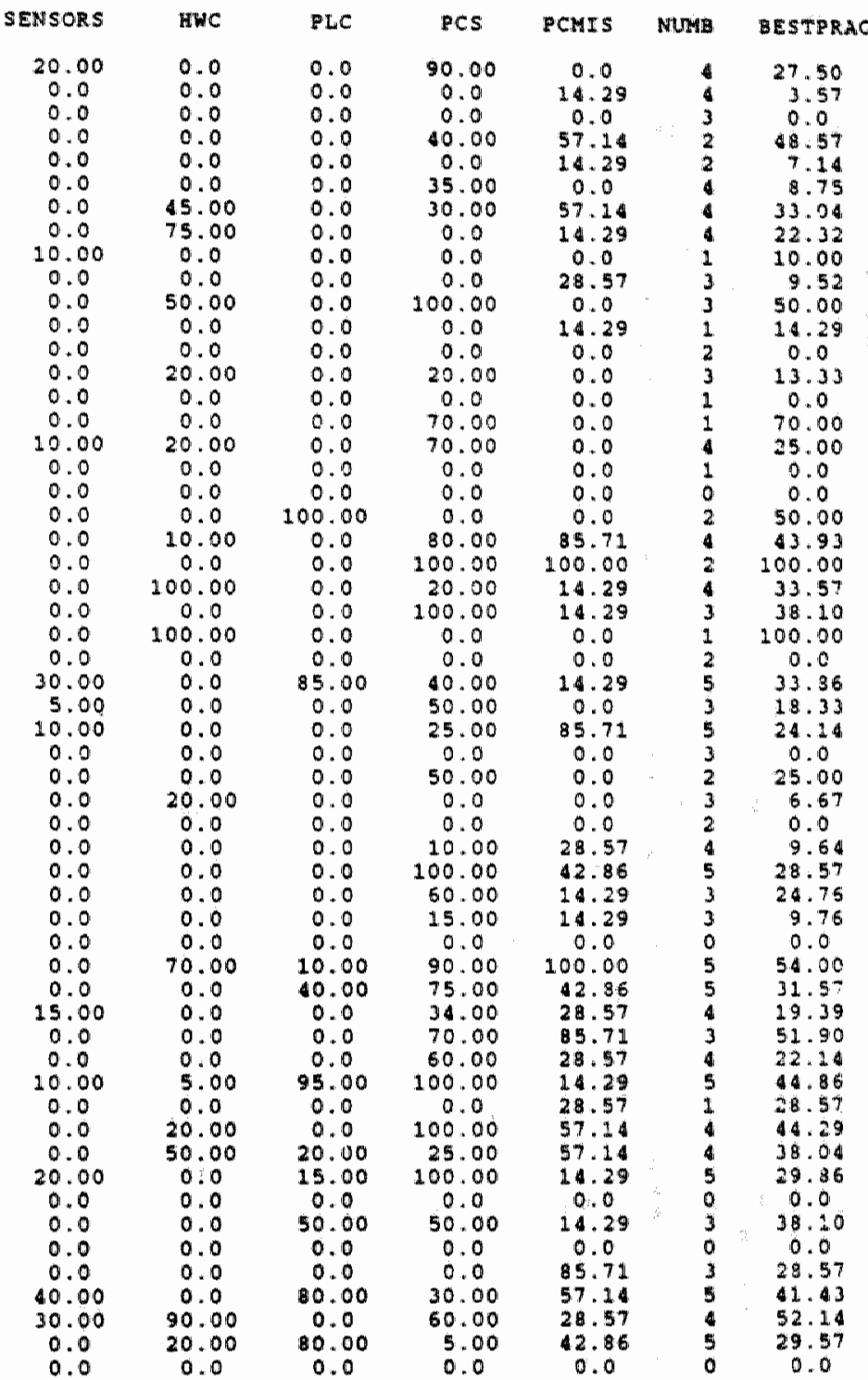

*) As all production control/management information systems are best practice, this measure for best practice has been modified. In the questionalre companies producing this key-element were asked how many of a total of seven functions were integrated in their system. Best practice technology has been measured by the 'scores' of functions from a total of $100 \%$. 
SCORES ON IWDICATORS OF IWNOVATION AND IWWOVATION STRATEGIES FOR P.C.E. COMPANTES

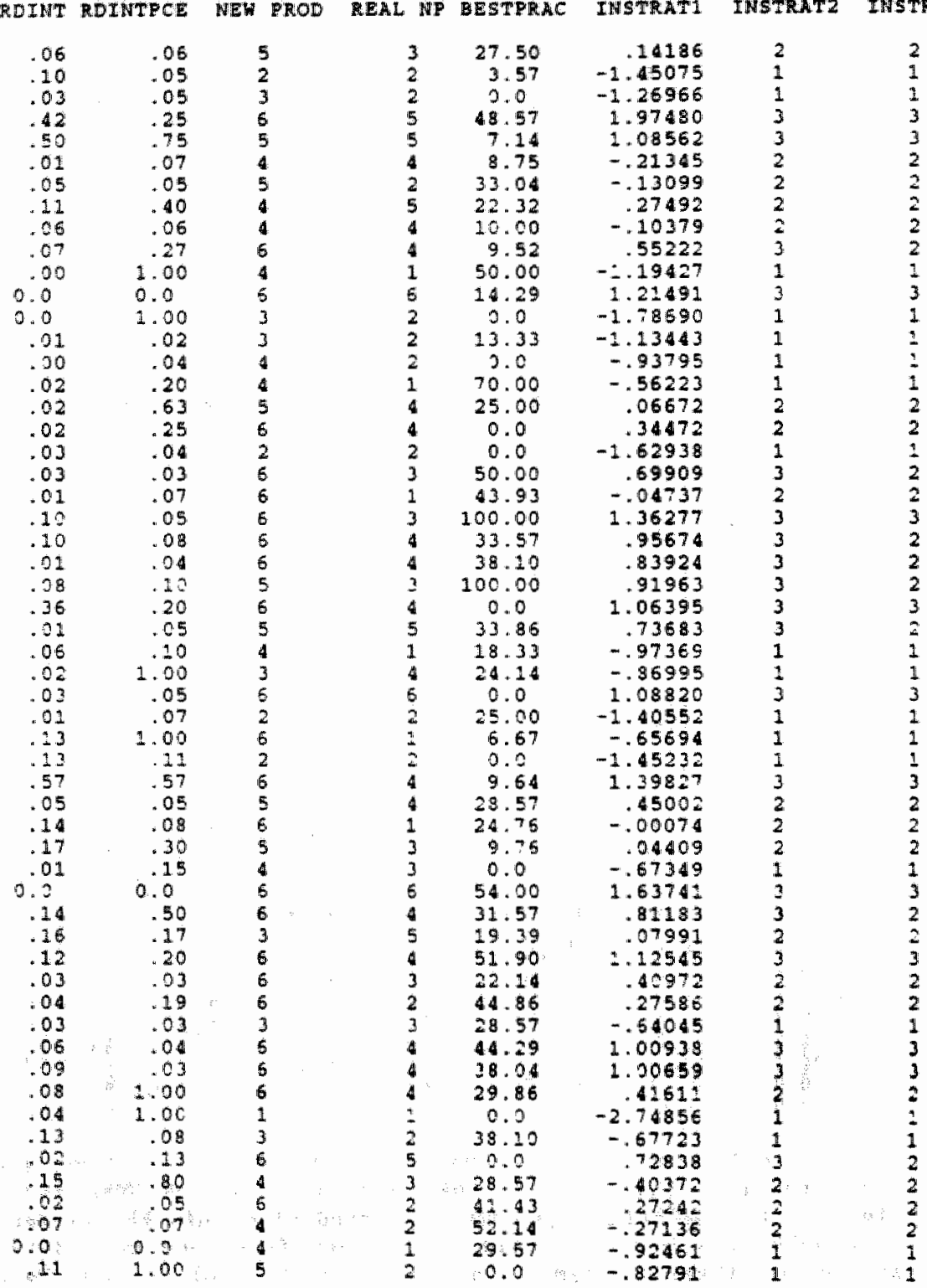




\section{BIBLIOGRAPEY}

Adams, (1953). Competition, monoly and countervailing power, in: Quarterly Journal of Economics, Vol. 67 , no. 4 .

Aglietta, M. (1979), A theory of capitalist regulation, London, NLB.

Mlexander, A.J. and B.M. Mitchel1, (1985), Measuring technological change of heterogeneous products, in: Technological Forecasting and Social Change, Vol. 27 , no. $2 / 3$.

Angelmar, R., (1985), Market structure and research intensity in high-technological-opportunity industries, in: Journal of Industrial Economics, Vol. 34, no. 2.

Arnold, E., (1985), Competition an technological change in the television industry, an empirical evaluation of theories of the firm, London, Macmillan.

Baran, P.A., and P.M. Sweezy, (1966), Monopoly Capltal, Middlesex, Penguin Books.

Barney, J.B. and W.G. Ouchi (ed.), (1986), Organizational econonics, London, Jossey-Bass.

Becker, J.F., (1971), on the monopoly theory of monopoly capitalism, in: science and society, Vol. 25, no. 4.

Bellofiore, $\mathbb{R}$., (1985), Money and development in schumpeter, in: Review of Radical Political Economics, Vol. 17 , no. 1 \& 2 .

Bellofiore, R., (1985), Marx after schumpeter, in: Capital and Class, no. 24 .

Belt, H. van den and A. Rilp, (1987), The Nelson-Vinter-Dosi model and synthetic dye chemistry, in: W.E. Bijker, T.H. Hughes and T. Pinch.

Ben-zion, U. and D.J. Fixler, (1981), Market structure and product innovation, in: Southern Economic Journal, Vol. 48, no. 2 .

Bilderbeek, R.H. and B.C.M. Mlders, (1988), Mdvanced production aystems and training implications, in: U.L. Buitelaar (ed.), Technology and work: debates frow England, Gerwany and Holland, Mldershort, Gover.

Blair, J.M., (1972), Econowic concentration, London, BBJ.

Blaug, M., (1983(1962)), Economic theory in retrospect, cambridge, CUP.

Bound, J., C. Cumins, $z$. Grilliches, B.H. Hall and A. Jaffe, $(1984)$, who does $R$ aD and who patents? In: $Z$. Grilliches. 
Bradley, I. and M. Howard, (1982), Classical and Marxian political econory, London, Macmilian.

Braverwan, H., (1974), Labor and monopoly capital, New York, Monthly Review Press.

Brown, L.A., (1984), Innovation diffusion, New York, Methen.

Bryan, $\mathbb{R}$, (1985), Monopoly in Marxist nethod, in: Capital and Class, no. 26 .

Bryan, R., (1986), Competition and monopoly: a reply, in: Capital and Class, no. 30 .

Burkett, F., (1986), A note on competition under capitalism, in: Capital and class, no. 30.

Bijker, M.E., T.P. Hughes and T. Pinch (eds.), (1987), The social construction of technological systems, Cambridge, MIT Press.

Caste11s, M. (ed.), (1985), High technology, space and society, Beverly Hil1s, Sage Publications.

Cayseele, P. van and Schreuder, H., (1988), De economische inbreng in de strategiebepaling van ondernemingen: een overzicht, Working paper, University of Limburg.

Chamber1in, E.H., (1951), The impact of recent monopoly theory on the schumpeterian system, in: S.E. Harris (ed.).

Chandler Jr., A.D., (1977), The visible hand: the managerial revolution in American business, Cambridge, Belknap.

Chandler Jr., A.D. and H. Daens, (1980), Managerial hierarchies, Cambridge, Harvard University Press.

Chappell Jr., H.W., J.T. Pietrowsi and R.P. Nilder, (1986), Rd.D, firm size and concentration: Evidence from the PTC Line of Business Survey, in: Quarterly Journal of Business and Economics, Vol. 25 , no. 2 .

Chesnals, $F$, (1982), Schumpeterian recovery and the schumpeterian perspective - Sone unsettled issues and alternative interpretations, in: H. Giersch (ed.). Emerging technologies: Consequencies for economic growth, structural change, and employment, Tubingen, Mohr.

Chesnals, r.. (1986), Some notes on technological cumulativeness, the appropriation of technology and technological progressiveness in concentrated narket structures, paper for conference Venice.

Claeys, G, and F. Kerr, (1981), Kechanical political econony, in: Cambridge Journal of Economics, no. 3. 
Clark, N. (1986). Introduction: economic analysis and technological change - a review of some recent developments, int R. Mac Leod.

Clark, N, and C. Juma, 1987), Long-run economics, an evalutionary approach to economic growth, London, Frances Pinter.

Clemence, R.V. and F.S. Doody, (1966), The Schumpeterian system, New York, A.M. Relley.

Clifton, J.A., (1977), Competition and the evolution of the capitalist mode of production, in: Cambridge Journal of Economics, Vol. 1, no. 2 .

Clifton, J.A., (1983), Administrered prices in the context of capitalist development, in: Contributions to Political Economy, Vol. 2 .

Cohen, H.M., R.C. Levin and D.C. Mowery, (1987), Firm size and RED intensity: A re-examination, in: Journal of Industrial Economics, Vol. 35, no. 4 .

Coombs, R., P. Saviotti and V. Walsh, (1987), Economics and technological change, London, Macmillan.

Cowling, K., (1982), Monopoly capitalism, London, Macmillan.

C.P.B., (1987), Technological innovation and its impact on international trade, "s-Gravenhage, C.P.B.

Culbertson, J.D., (1985), Econometric tests of the market structural determinants of R\&D investment: Consistency of absolute and relative firm size models, in: Journal of Industrial Economies, Vo1. 34 , no, 1 .

Curran, J., J. Stanworth and D. Watkins (eds.), (1986), The survival of the small firms, Vol. 1 and 2, Hants, Gower.

Cutler, A., B. Hindess, P. Hirst and A. Hussain, (1977, 1978), Marx"s Capital and capitalism today, Vol. 1 and 2 , London, RKP.

cutting, G., (1984), Paradigms, revolutions and technology, in: R. Laudan.

David, P.A." (1984), The reaper and the robot, Norking paper, Stanford University.

David, P.A., (1986), Technology diffusion, public policy, and industrial competitiveness, in: $R$. Landau and $N$. Rosenberg (ed.), The positive sum strategy, Harnessing technology for economic growth, Washington, National Academy of Sclences.

David, P.R. and T.E. Olsen, (1986), Equilibrium dynamies of diffusion when incremental technological innovations are foreseen, Working paper, stanford University. 
Deleplace, G., (1981), Marche et concurrence chez Marx " in: Cahiers đ' Economic Politique, no. 6.

Demele, 0 . and $W$. Semiler, (1980), Ronkurrenz und Monopol, in: idem, Monopol Theorie, Rontrovers, Berlin, olle Wolter.

Devilne, P.J., T. Lee, R.M. Jones and W.J. Tyson, (1985), An introduction to industrial economics, London, George Allen \& Unwinn.

Dobb, M., (1972), Political econony and capitalisw, London, RKP.

Dabb, K., (1981(1973)) Theories of value and distribution since Adam smith, Ideology and economic theory, Cambridge, CUP.

Dorfman, N.S., (1987), Innovation and market structure, lessons from the computer and semiconductor industries, cambridge, Ballinger.

Dosi, G. (1982), Technological paradigms and technological trajectories, in: Research Policy, Vol. 11, no. 3.

Dosi, G. (1983). Technological paradigns and technological trajectories, in: $c$. Freeman (ed.). Long waves in the world econony.

Dosi, G., (1984), Technical change and industrial transformation, London, Macmillan.

Dosi, G., and L. Orsenigo, (1985), Order and change. An exploration of markets. institutions and technology in industrial dynamics, SPRU-DRC discussion paper no. 32.

Dugger, W., (1985). The continued evolution of corporate power, in: Review of Sacial Economy, Vol. 43.

Dumenil, $G$, and D. Levy, (1987), The dynamics of competition: $A$ restoration of the classical analysis, in: Cambridge Journal of Economies, Vol. 11, no. 2 .

Eatwel1, J. "(1982), Competition, in: I. Bradley and $M$. Howard.

EIRMA, (1982). The role of RAD in the innovation process, Paris. EIRHA.

BIRMA, (1983), How much R\&D?, Paris, EIRMA.

E1Liot, J.Z., (1980), Marx and schumpeter on capitalisu"s creative destruction: a comparative restatenent, in: Quarterly Journal of Economics, Vol. 94, August.

Elliott, J.E., (1983), schumpeter and the theory of capitalist conomic development, in: Journal of Economic Behavior and organization, Vol. 4 , no. 4. 
Elliott J.E., (1985), Schumpeter's theory of economic development and social change: Exposition and assessment, in: International Journal of Social Economics, Vol. 12, now 6 .

Elster, J., (1983), Explaining technical change, cambridge, cuP.

Ettlie, J.E. and A.H. Rubenstein, (1986), Firm size and product innovation, Norking paper ITI, Ann Arbor.

Fels, R. (ed.), (1964), Abridged edition of Schumpter"s Business cycles, New York, Kcoraw Hill.

Foster, J.B., (1981), Is monopoly capitalism an illusion? In: Monthly Review, Vol. 33, no. 4.

Foster, J.B., (1983), Theories of capitalist transformation: Critical notes on the comparison of Marx and schumpeter, in: Quarterly Journal of Economics, Vol. 98 , no. 2 .

Foster, J.B., (1984), The political economy of Jaseph schumpeter: A theory of capitalist development and decline, in: studies in Political Economy, no. 15.

Foster, J.B." (1986), The theory of monopoly capitalism, New York, Monthly Review Press.

Foster, J.B. and H. szajfer leds.), (1984), The faltering economy: The problem of accumulation under monopoly capitalism. New York, Monthly Review Press.

Freeman; C., (1982), The economics of industrial innovation, London, Frances Pinter.

Freeman, C., (1987), Diffusion: The spread of new technology to firms, sectors and nations, SPRU-paper.

Freeman, C., J. Clark and L. Soete, (1982), Unemployment and technical innovation, London, Frances Pinter.

Freeman, C. and C. Perez, (1986). The diftusion of technical innovations and changes of the techno-econonic paradigm, Paper presented at the conference on innovation diffusion. Venice.

Freesan, C. and L. Soete (eds.), (1987), Technical change and exployment, oxford, Blackvell.

Freeman, C. and L. Soete, (1987), Information technology and change in the techno-economic paradign, in: $C$. Freeman and $L$. soete (eds.).

Frisch, H. (ed.), (1981), Schumpeterian economics, New York, Praeger.

Galbraith, J.K., (1970(1952)) American capitalism, Middesex, Penguin Books. 
Galbraith, J.R., (1985(1967)) The new industrial state, New York, MAL.

Glick, M., (1985), Monopoly or competition in the us econony, in: Review of Radical Political Economics, Vol. 17, no. 4.

Gold, B., (1981), Technological diffusion in industry: research needs and shortcomings, in: Journal of Industrial Economics, Vol. 29 , no. 3 .

Gold, B., (1983), On the adoption of technological innovations in industry: superficial models and complex decision processes, in: $\mathrm{S}$. MacDonald, D. Md. Lamberton. T.O. Manderille (eds.), The trouble with technology.

Grahl, J., (1985), Creative destruction: the significance of Schumpeter: economic doctrines, in: Cahiers d'Economie Politique, no. 10-11.

Granstrand, $0 .,(1982)$, Technology, management and markets, London, Frances Pinter.

Grilliches, 2. (ed.), (1984), R\&D, patents and productivity, Chicago, NBER.

Grossman, H., (1972), Marx en de klassieke politieke economie, in: TEU, no. $7 / 8$.

Gutting, G., (1984), Paradigms, revolutions and technology, in: R. Laudan (ed.).

Hagedoorn, J., (1984), some recent contributions in neoSchumpeterian economic theory, STB-TNO paper.

Hagedoorn, J." P. Kalff and J. Korpel, (1988), Technological development as an evolutionary process, Amsterdam, Elsevier science.

Hagedoorn, J. and J. Schot, (1988), Co-operation between companies and technological development, STB-TWO paper.

Hansen, A.H." (1951), schumpeter"s contribution to business cycle theory, in: S.E. Harris (ed.).

Harris, S.E. (ed.), (1951), schumpeter, social scientist, Cambridge, Harvard University Press.

Harvey, D., (1982), Limits to capital, Chicago University Press.

Hatten, K.J. and M.L. Hatten, (1987), strategic groups, asymetrical mobility barriers and contestability, in: strategic Management Journal, Vol. 8.

Hay, D.A and D.J. Morris, (1980), Industrial economics, theory and evidence, Oxford, OUP. 
Heertje, A., (1977), Economics and technical change, London, Veidenfeld Nicolson.

Rilferding, R., (1968(1909)), Das Finanzkapital, Frankfurt, Europăische Verlagsanstalt.

Hope, E., (1985), Innovation in high technology industries, Vorking paper Norwegian School of Economics and Business Administration.

Eughes, T.P., (1987), The evolution of large technological systems, in: W.E. Bijker, T.P. Hughes and T.J. Pinch.

Hymer, S.H., (1979), The multinational corporation, a radical approach, Cambridge, cup.

Jacquemin, A., (1986), Sélection et pouvoli dans la nouvelle écononie industrielle, Louvain-la-Neuve, Cabay.

Johnson, P., (1986), New firms, an economic perspective, London, Allen Unwinn.

Jong, H.W. de, (1981), Dynamische markttheorie, Leiden, stenfert Kroese.

Kamien, M.I. and N.L. Schwartz, (1975), Market structure and innovation: A survey, in: Journal of Economic literature, vol. 13.

Ramien, M.I. and N.L. Schwartz, (1982), Market structure and innovation, Cambridge, cUP.

Kaplinsky, R., (1983), Firm size and technological change in a dynamic context, in: Journal of Industrial Economics, Vol. 32 , no. 1 .

Kaplinsky, R., (1984), Automation, the technology and society, Harlow, Longman.

Ray, N.M., (1979), The innovating firm, London, Macmillan.

Kerlinger, F.N*, (1969), Foundations of behavioral research, London, Holt "Rinehart vinston.

Keine, J. (1983), Investitionsverhalten bei Prozessinnovationen, Frankfurt, Campus.

Rnight, R.E., (1985), A functional and structural measurement of technology, in: Technological Forecasting and social change, vol. 27 , no. $2 / 3$.

Rohn, M. and J.T. Scott, (1982), Scale economies in research and development: the schumpeterian hypothesis, in: Journal of Industrial Economies, Vol. 30 , no. 3 .

König, H. and K. Zimmerman, (1986), Innovations, market structure and market dynamies, in: Journal of Institutional and Theoretical Economies, Vol. 142, no. 1. 
Norsch, R., (1972), Rar1 Narx, Frankfurt, Europaische Verlagsanstalt.

Rrege1, J.A., (1985), Is the invisible hand a Fallacy of composition"? Swith, Marx, Schupeter and Reynes as economic orthodoxy, in: Cahiers d"Economie Politique, no. 10-11.

Ruhn, T.S., (1974(1962)) The structure of scientific revolutions, Chicago University Press.

Kuhn, T.S., (1977), The essential tension: tradition and innovation in scientific research, in: idem, The essential tension, Chicago University Press.

Kühne, K., (1979), Economics and Marxism, 2 volumes, London, Macmillan.

Ruruma, s., (1973), Marx Lexikon zur politischen oekonomie Ronkurrenz, Berlin, Oberbaum.

Lange, 0., (1943), A note on innovations, in: Review of Economics and statistics, Vol. 25.

Laudan, R* (ed.) (1984), The nature of technological knowledge. Are models of scientific change relevant?, Dordrecht, Reidel.

Lebowitz, M.A." (1985), The theoretical status of monopoly capital, in: S. Resnick and $R$. Nolff.

Lenin, V.I., (1973), Het imperialisme als hoogste stadium van het kapitalisme, Moskou, Progres.

Lenz, R.C., (1985), A heuristic approach to technology measurement, in: Technological Forecasting and social Change, Vol. 27 , no. $2 / 3$.

Levin, R.R., W.M. Cohen and D.C. Hovery, (1985), $R \& D$ appropriability, opportunity and market structure: New evidence on some Schumpeterian hypotheses, in: American Economic Review, Vo1. 75, no. 2.

Levin, R.C. and P. Reiss, (1984), Tests of a schumpeterian model of RED and warket structure, in: $z$. Grilliches.

Link, A.N. " 1980), Firm size and efficient entrepreneurial activity: A reformulation of the schumeter hypothesis, in: Journal of Political Econony, Vol. B8, no. 4.

Lipietz, A., (1986), Behind the crieis: The exhaustion of a regime of accumulation, in: Review of Radical Political Economics, Vol, 18 , no. 1 and 2 .

Lunn, J. and $S$. Martin, (1986), Market structure, firm structure and RLD, in: Quarterly Review of Economics and Business, Vol. 26, no. 1 .

Macleod, R. (ed.), (1986), Technology and the human prospect, London. Frances Pinter. 
Mahajan, V. and R.A. Peterson, (1985), Nodels for innovation diffusion, Beverly Hills, Sage Publishers.

Mansfield, E. (1984), R\&D and innovation: some empirical findings, in: 2 . Grilliches.

Marco, L.W.A., (1985), Entrepreneur et innovation: les sources françaises de Joseph schumpeter, in: Economies et societes, vol. 19, no. 10 .

Marx, R. (1971), Critique of political economy, New York, International Publishers.

Marx, K. "(1974), Grundrisse der Rritik de politischen Oekonomie. Berlin, Dietz Verlag.

Marx, K., (1973(1847)) The poverty of philosophy, New York, International Publishers.

Marx, K., (1983(1867)) Capital I, London, Lawrence \& Wishart.

Marx, K., (1977(1885)) Capital II, London, Lawrence * Wishart.

Marx, K., (1977(1894)) Capital III, London, Lawrence Wishart.

Marx, K., (1981), Die technologisch-historischen Exzerpte, Frankfurt, Ulistein.

Marx, K., (1982), Exzerpte aber Arbeitsteilung, Maschinerie und Industrie, Frankfurt, vilstein.

Marx, R. and F. Engels, (1968(1872)) Comunistisch Manifest, Ansterdam, Pegasus.

Marx, K. and F. Engels, (1972(1888)) De Duitse ideologie, Nijmegen, Sun.

Mason, E.S., (1951), Schumpeter on monopoly and the large firm, in: S. I. Harris (ed.).

Mc.Gee, J., (1985), strategic groups: A bridge between industry structure and strategic management?, in: H. Thomas and D. Gardner (eds.). strategic warketing and management. London, John liley and Sons.

Mc.Gee, J. and H. Thomas, (1986), strategic groups: Theory, research and taxonomy, in: strategic Management Journal, Vol. 7 .

WeNulty, P., (1984), on the nature and the theory of economic organization: The role of the firm reconsiderd, in: History of Political Economy, Vol. 16.

Nehrwert, (1976), Einzelwirtschaftliche Grundbegriffe und Beziehungen, zur Kritik der Betriebswirtschaftslehre, no. 3 .

Netcalfe, J.S., (1981), Impulse and diffusion in the study of technological change, in: Futures, Vol. 13 , no. 5. 
Mishra, R. (1979), Technology and social structure in Marx"s theory: an exploratory analysis, in: Science and society, Vol. 43. no. 2 .

Morishima, H., (1984), The economics of industrial society. Cambridge, CuP.

Mowery, D.C., (1985), Market structure and innovation: critical survey, unpublished paper.

Hueller, D.C., (1986), The modern carporation, Brighton, Theatsheaf.

Nabseth, L. and G.F. Ray, (1974), The diffusion of new industrial processes, Cambridge, CUP.

Melson, R.R., (1959), The simple economics of basic scientific research, in: Journal of Political Econony. Vol. 67.

Nelson, R.R., (1987), Understanding technical change as an evolutionary process, Amsterdam, North Holland.

Nelson, R.R., M. Peck and E. Kalachek, (1974). The concentration of RED in large firms, in: E. Mansfield (ed.), Monopoly power and economic performance. New York, Norton.

Nelson, R.R. and S.G. Winter, (1977), In search of useful theory of innovation, in: Research Policy, Vol. 6, no. 1.

Nelson, R.R. and S.G. Winter, (1982), An evolutionary theory of economic change, Cambridge, Harvard University Press.

OECD, (1982), Innovation in small and medium sized firms, Paris, OECD.

Pakes, A. and M. Schankermann, (1984), An exploration into the determinants of research intensity, in: $z$. Grilliches.

Pavitt, K., (1984), Sectoral patterns of technical change: towards taxonomy and theory, in: Research Policy, vol. 13.

Pavitt, K., K. Robson and J. Townsend, (1985), The size distribution of innovating firms in the UK: 1945-1983, SPRU paper.

Pavitt, K.. M. Robson and J. Townsend, (1986), Aresh 100 at the aize distribution of innovating firas, SPRU paper.

Pavitt, R., M. Robson and J. Townsend (1987), The size distribution of innovating firms in the ux: 1945-1983, in: Journal of Industrial Economics, vol. 35, no. 3 . Philips, A., (1971), Technology and market structure, Lexington,
Lexington Books.

Pieterson, M. (ed.), (1981), Het technisch labyrint, Ansterdam,
Boom. 
Piore, K.J. and C.F. Sabel, (1984). The second industrial divide - possibilities for prosperity. New York, Basic Books.

Pol, R. van der, (1981), Marx contra Ricardo, Goningen, Uolters Noordhoff.

Forter, M.E., (1985), Competitive advantage, creating and sustaining superior performance, Newa, Free Press.

Porter, M.E., (19B6), The contributions of industrial organization to strategic management, in: J.B. Barney and .G. ouchi (eds.).

Prakke, F., (1987), Introducing CTM in the factory organiation, paper for Esprit CIM Europe Conference.

Pratten, C., (1986), The importance of giant companies, in Lloyds Bank Review, no. 159.

Ray, G.F., (1984), The diffusion of mature techmologies, Cambridge, CUP.

Reati. A., (1986), The rate of profit and the organic composition of capital in West German Industry from 1960 to 1981 , in: Review of Radical Political Economics, Vol. 18, no. 1 and 2 .

Reid, G.C., (1979), An analysis of the firm, narket structure and technical progress, in: Scottish Journal of Political Econony, Vo1. 26 , no, 1 .

Reingaum, J.F, (1985), Innovation and industry evolution, in: Quarterly Journal of Economies, no. 100 .

Resnick, S. and R. Nolff, (1985), Rethinking Marxism, Essays for Harry Magdof \& Paul Sweezy, New York, Autonomedia.

Roemer, J.E., (1979), Continuing controversy on the falling rate of profit: fixed capital and other issues, in: Cambridge Journal of Economics, Vol. 3, no. 4.

Roobeek, A.J.M., (1987), De rol van de technologie in de econonische theorievorming, Ansterdan, Scheltema Holkema Vermeulen.

Rosegger, G., (1980). The economics of production and Innowation, Elmsford, Pergamon Press.

Rosenberg, J.B., (1976), Research and market share: A reappraisal of the schumpeter hypothesis, in: the Journal af Industrial Economics, Vol. 25, no. 2 .

Rosenberg, N., (1976), Marx as a student of technology in: Monthly Review, no. 3, reprinted in: iden, Inside the black box: technology and economics.

Rosenberg, N., (1976), Perspectives on technology, Canbridge, CUP. 
Rosenberg, N., (1982), Inside the black box: technology and economics, Cambriage, cup.

Rosenberg, $H_{*}$ (1986), Schumpeter and Wark: how comon a vision? In: Macheod (ed.), Technology and the buman prospect.

Rosenberg, N. and L.E. Birdzell Jr., (1986), How the Nest grew rich, New York, Basic Books.

Rothwell, R., (1986), The role of small firms in technolagical innovation, in: J. Curran, et al.

Rotbwell, R. and W. Zegreld, (1982), Innovation and the small and medium sized firti, London, Frances Pinter.

Rowthorn, B. and D.J. Harris, (1985), The organic composition of capital and capitalist development, in: $s$. Resnick and $R$. Wolft.

Sahal, D.. (1981), Patterns of technological innowation, Reading, Addison-Vesley.

Sahal, D.; (1983), Technology, productivity, and industry structure, in: Technological Forecasting and social Change, vol. 24.

Saha1, D., (1985), Foundations of technometrics, in: Technological Forecasting and social Change, vol. 27.

Saviotti, P.P., (1985), An approach to the measurencht of technology based on the hedonic price method and related methods, in: Technological Forecasting and Social Change, Vol. 27 no. $2 / 3$.

Saviotti, P.P. and J.S. Metcalfe, (1984), A theoretical approach to the construction of technological output indicators in: Research Policy, Vol. 13.

Saviatti, P.P. P.C. Stubbs, R.H. Coombs and M. Gibbons, (1982)" An aproach to the construction of indexes of technological changes and of technological sophistication, in: Technological Forecasting and social change, vol. 21.

Saryer, M.C.., (1981). The economics of industries and firms, London, Croom He1m.

Scherer, F.M., (1965), Firm size, market structure, opportunity, and the output of patented inventions, in: American Economic Review, Vol. 15, no. 5.

Scherer, F.M., (1980). Industrial narket structure and economic performance, Chicago, Rand Mowally. Scherer, F.M., (1984), Innovation and growth - Schumpeterian
perspectives, Cambridge, WIT Press.

Schumpeter, J.A., (1923), Unternehmen, in: Handwörterbuch der statswissenschaten, Jena, G. Fischer. 
Schumpeter, J.A., (1980(1934)) The theory of economic development, London, Oxford University Press.

Schumpeter, J.A., (1939), Business Cycles, New York, Mc GrawHill.

Schumpeter, J.A., (1975(1942)), Capitalism, socialism and denocracy, New York, Harper \& Row.

Schumpeter, J.A., (1949), Bconomic theory and entrepreneurial history, in: Change and the entrepreneur, Postulates and patterns for entrepreneurial history, Cambridge, Harvard University Press.

Schumpeter, J.A., (1986(1954)) History of economic analysis, London, Mllen \& Unwin.

Scott, J.T., (1984), Firm versus industry variability in RED intensity, in: $\mathrm{Z}$. Grilliches.

Semier, W., (1982), Theories of competition and monopoly, in: Capital and Class, no. 18 .

Semler, W., (1982), Competition, monopoly and differentials of profit rates: theoretical considerations and empirical evidence, in: Review of Radical Political Economics, Vol. 13, no. 4.

Semmler, V., (1983), Competition, monopoly and differentials of profit rates: a reply, in: Review of Radical political Economics, Vol, 15, no. 4.

Semmler, (1984), Competition, monopoly and differential profit rates, New York, Columbia University Press.

Semler, M., (1984), Marx and schumpeter on competition, transient surplus profit and technical change, in: Economie appliquee, Vol. 37 , no. $3 / 4$.

Semmler, W., (1985), Marxian conception of competition, paper.

Shaw, R.V. and C.J. Sutton, (1976), Industry and competition, London, Mac Millan.

Shaw, ".H., (1979), "The handmill gives you the feudal lord': Marx"s technological determinism, in: History and Theory, no. 18 .

Sherman, H.J., (1983), Monopoly power and profit rates, in: Review of Radical Political Economics, Voll. 15, no. 2 .

Sherman, B.J., (1985), Monopoly capital vs the fundamentalists, in: $s$. Resnick and $R$. Molff.

Shimshoni, D., (1970), The mobile scientist in the american instrument industry, in: Minerva, Vol. 8, no. 1 . 
Shrieves, R.2., (1978), Karket structure and innovation: a new perspective, in: Jouraal of Industrial Economics, Vol, 26.

Smith, A. (1985(1776)), The vealth of nations, Middlesex, Perguin Books.

Smithies, A., (1951), Memorial: Joseph Mlois Schumpeter, 18831950, in: S.. Harris (ed.).

Soete, Li, (1978), Inventive activity, industrial organization and international trade, PhD University of sussex.

Soete, L. (1979), Firm size and inventive activity - the evidence reconsidered, in: European Bconomic Review, no. 12.

Soete, L.L.G., (1979), Size of firm, oligopoly and research: a reappraisal, in: Reseaux, no. 35-36.

Soete, L., (1985), Electronics, in: L. Soete (ed.), Technological trends and employment, 3 Electronics and communications, Hants, Gower.

Soete, L., (1987), sectoral and technological taxonomies: an 'integrative' analysis based on innovation statistics, in: C.P.B.

Soete, L. and G. Dosi, (1983), Technology and employment in electronics industry, London, Frances Pinter.

Soete, $L_{*}$ and $R$. Turner, (1984), Technology diffusion and the rate of technical change, in: The Economic Journal, no. 94.

Steedman, I., et al, (1981), The value controversy, London, Verso.

stolper, W.F., (1981), Aspects of schumpeter"s theory of evolution, in: H. Frisch.

stoneman, P., (1983). The economic analysis of technological change, oxford, oup.

Storper, K., (1985), Technology and spatial production relations: disequilibriun, interindustry relationships, and industrial development, in: H. Castells (ed.).

Sutton, C.J., (1980), Economics and corporate strategy. Cambridge, cup.

Sweezy, P.H., (1943), Professor schumpeter's theory of innovation, in: Review of cconomic statistics, Vol. 25.

sweezy, P.M, (1968(1942)), The theory of capitaligt development, New York, Monthly Review Press.

Sweezy, P.M. (1972), Hodern capitalism and other essays, New
York, Monthly Review Press. 
Sweezy, P.M., (1981), Four lectures on Marxism, New York, Monthy Review Press.

sylos-tabini, P., (1984), The forces of economic growth and decline, Cambridge, M.I.T. Press.

Taymans, A.C., (1951), Marx's theory of the entrepreneur, in the American Journal of Economics and Sociology.

Teece, D.J., (1986), Capturing value from technological innovation: Integration, strategic partnering, and licensing decisions, Paper for Venice Conference.

Thirtle, C.G. and V.W. Ruttan, (1987), The role of dewand and supply in the generation and diffusion of technical change, Chur, Harwood.

Utton, M.A., (1982), The political economy of big business, Oxford, Martin Robertson.

Walker, R.A., (1985), Technological determination and determinism: industrial growth and location, in: M. Castells (ed.).

Nebber, M.J. and D.L. Rigby, (1986), The rate of profit in Canadian manufacturing, 1950-1981, in: Review of Radical Political Ecomomics, Vol. 18, no. 1 and 2 .

Weeks, J., (1981), Capital and exploitation, London, Bdward Arnold.

Theelock, J., (1983), Competition in the Marxist tradition, in: Capital Class, no. 21.

Wheelock, J., (1986), Competition and monopoly: a contribution to debate, in: Capital and class, no. 30.

Thitley, R.D., (1987), Types of technological research and their impact on occupational practices, paper Manchester Business School.

Villiams, P.L., (1982), Monopoly and centralization in Marx, in: nistory of Political Economy. Vol. 14, no. 2.

Villiamson, 0.E., (1975), Markets and hierarchies: Analysis and entitrust implications, Nev York, Free Press.

Nolff, E.K., (1986), The productivity slowdown and the fall in the us rate of profit, 1947-1976, in: Review of Radical Political Economics, Vol. 18 , no. 1 and 2 .

Wo11, H. (1980), Ronzentration und technischer Fortschritt, in: 0 . Demele and . Seminler.

Zuscovitch, E., (1986), The econonic dynamics of technologies development, in: Research Policy, Vol. 15, no. 4.

Zwan, A. van der and J. Verhulp, (1980), Grondslagen en techniek van de marktanalyse, Leiden, stenfert Rroeze. 
In deze studie wordt een bijdrage geleverd aan zowel een antal nieuwe ontwikkelingen in de theorfe rond innovatie en industriele ontwikkeling als de concretisering en ultwerking van dergelijke theorlevorming in empirisch onderzoek. Wat betreft de eerst genoende doelstelling wordt wangluiting gezocht bif de recente discussie rond de verdere ontwikeling van een antal heterodoxe bifdragen, wet name in het deelgebled van innovatie theorle en 'Industrial economica". Theoret1sche bijdragen dfe in dat kader in de belangsteling taan z1jn te viaden in het werk van onder andere Nelson en Winter, Freeman en Rosenberg. De uitwerking van een theoretisch kader is gebaseerd op heterodoxe theorlevoraing gedeeltelljk gebaseerd op het werk van "klassleke" auteurs zoals Marx en Schumpeter, maar ook op het werk vanuit meoSehumpeterlaanse en neo-Marxistische optiek en onderzoek van een meer multidisciplinair karakter zoals dat gestalte krijgt in bijdragen aan het onderzoek rond de ard en ffectiviteit van technologie-neting. In algemene $z$ in kan gesteld worden dat in deze studfe een kritische beschouwing van een aantal variamten van evolutionalre theorievorming rond technologie en Industriele verandering central staat. Daarbif gat het niet alleen ow de theorlevorming rond de veranderingen in de industriele structuur onder invloed van technologische ontwikkeling en vice-veraa mar er wordt tevens uftwoer Ig aandacht besteed aan het karakter van technologische verandering zelf warbij diffusie en innovatie als een organtach geheel worden gezten.

In het emplrisch onderzoek dat in dit kader wordt ultgevoerd staan de technologlache ontwikkelingen en veranderingen in de industr1sle structuur in de Internationale proces controle bector centraal. Het onderzoek betreft nilet zozeer een gelsoleerde sector atudie var veleer de relatie tussen verschillende velden van technologlache ontwikkeling zoals procestechnologlekn en informatietechnologie en varanderingen in de Induetriele structur in bredere $2 \mathrm{in}$. Bovendien stelt dit onderzoek on in stat andacht te besteden an een sector die 'verborgen' 18 in de officille economische atatiatlek. 
Zowel Marx als Schumpeter kunnen gezten worden als grondlieggers van een aantal theoretische aanzetten voor evolutlonalre theorlieworming rond technologle en economische veranderlng. Een belangrljk aspect in het werk van Marx is $21 \mathrm{fn}$ grote inhoudelljke aandacht voor het effect van technologlsche ontwlikeling op de matschapplj in het algemen en veranderingen in de economische structurur in het bijzonder. Deze aandacht kreeg vooral vorm in Marx"s analyse van de gevolgen van het proces van mechantsatile in de eerste helft van de 19 de eeuw warmee een eenzljdige en logisch onhoudbare economische krialstheorie werd gefundeerd wetgeen echter onverlet laat dat Harx een ongeevenaarde diepgang in zijn analyse van de effecten van technologische ontwlkkelingen introduceerde. Verspreid door het werk van Marx treft men tevens een grote andacht voor een differentlatie van ondernemingsvormen en categorleeln ondernemingen aan. In de ultwerking van een analytisch kader voor emplrisch onderzoek in deze studie is gebruik gemaakt van een vergelijkbare categorisatie van ondernemingen. In de analyae van Marx zelf is echter meer andacht besteed aan de rol van concentratle en centrallsatle bly de vorming van grote ondernemingen die een dominante rol in het economisch proces zouden gaan innemen.

Schumpeter besteedde duldelijk minder andacht aan de analyse van technologische ontwikkelingen dan Marx. In Schumpeter's economische theorie is innovatle eerst wellswar een gedeeltelifk endogene factor terwijl technologle in het algemeen toch vooral exogeen blijft. In het latere werk wordt technologle meer endogeen waarblf met name de rol van zogenamdle "aclence based" ondernemingen worden benadrukt.

Voor zowel Marx als Schumeter heeft technologlsche ontwlkkeling een evenulchtaverstorend effect op het proces van economische ontwikkeling.

In belde bifdragen wordt, In tegenstelling tot hetgeen in de 11teratuur veelal wordt gesteld, het behalen van een technologlsche vooraprong door innovatieve ondernemingen nlet gekoppeld an lange terwljn monopollewingten maat eerder aan korte termijn monopolleposities. Monopolle voortkomend ut de succesvolle introductie van 
nteuwe produkten en produktleprocessen heeft in de regel geen etructureel karakter, het is eerder gebaseerd op tijdelifke warktmacht en nlet ten principale afhankel1jk van de grootte van condernemingen.

In deze studle wordt veel andacht besteed aan een noodzakelifk geachte differentlatie van ondernemingen nar grootte en functie. B1f Schumeter vindt men een basle voor een verdere differentlatie In grote, veelal "acience based", ondernemingen, kleinere ondernemingen warin de entrepreneur een centrale plaats imneewt en, vooral in $21 j \mathrm{n}$ latere werk, kletne en middelgrote ondernemingen in een toleveringafunctle of opererend in specifleke narkt-niches. Onder Invioed van het verschifnsel van creatleve destructie waarblj nleuwe sectoren en ondernemingen gaan ontstaan worden zowel. nleuw opgerichte ondernemingen als 'cross entry' categorieën die b1j een analyse van structuurverander1agen kumnen worden opgenomen In een analytlsch kader. In het werk van Marx vindt men tal van verwljzingen naar het belang van centralisatie en concentratie voor het ontstaan van grote ondernemingen terwj1 ook het belang van kleInere Innovatieve ondernemingen wordt benadrukt. In tegenstelling tot de "Jonge" Schumpeter heeft Marx weinig aandacht voor de entrepreneur als personificatle van innovatie, hetgeen gezlen de aard van de ontwlkkelingen van moderne technologie terecht is. Het 1 van belang te benadrukken dat wat betreft de analyoe van de rol van grote ondernemingen in de veranderingen van marktgtructuren er een grote mate van overeensteming is tusgen het werk van Marx de latere bifdragen van schumpeter.

Voortboumend op het werk van Marx en vooral schumeter afja er de afgelopen decennla tal van blfdragen geleverd an de theorlevorming rond technologische ontwlkkeling en sepecten van econonioche atructuurveranderingen, zoals de rol van ondernemtngen van verwhllende grootte en Industritle concentratie.

In neo-karxlstlache bljdragen kan wen grofweg twee varianten binnen deze theorie onderscheiden. In een vartant wordt de $11 \mathrm{fn}$ van Marx Inzake centrallat le en concentratle verder doorgetrokken natr een monopolietheorle warin het kspltalistische economiache 
ctelsel wordt gedowineerd door zeer grote monopiolle-ondernentngen, hetgeen resulteert in een eenvoudige dichotone econonlsche atructuur met enerzijds monopolfe-ondernemingen en anderzijds een groep van kleine ondernemingen. In een andere vartant van de radicale politieke econonle wordt veeleer anslutting gezocht blf de klassieke economische theorte warin wonopolie, zeker in het $11 \mathrm{cht}$ van Innovatle, wordt gezien als onafhankelljk van onderneningsgrootte en erder verbonden wet het behalen van tifdelifke extra-Insten als gevolg van het behalen van een technologlsche voorsprong.

In deze studle wordt de radicale theorle van bet monopolle-kapltallome zoals onder andere ontwlkkeld door sweezy bekritlseerd. Kenmerkend voor deze neo-Marxlstische theorfe van het monopollekapitalisme 18, naast het reeds gememoreerde eenvoudige twee sectoren model met een monopolistische en een niet-monopolistiache sector, dat het kapitalisme wordt geanalyseerd als een statisch systeem. Technologtsche ontwlkkeling wordt niet geanalyseerd als een dynamische factor warbif creatleve destructle tot veranderingen van Industriele structuren zal lelden. Comcurrentle wordt, ten onrechte, gezien als een centraal element van vroegere fasen van het kapitalisme, Een bijkomend, max niet onbelangrjjk bezwar, Is dat de operationalisatie van het begrip monopollekapitaal in meer concrete analyses of aanzetten daartoe nogal slord1g wordt gehanteerd.

In sommige neo-Schumpeterlaanse b1jdragen zien we een vergelijkbare statische variant van de theorle. Het name bif Galbralth wordt zowel de technologlsche als de economische ontwikkeling gedomineerd door zeer grote ondernemingen bimnen een statloche structuur arin andere groepen ondernemingen en de opkonst van nieuve aectoren welnig relevantle hebben. Een belangrljke consequentle van dergelljke theorlevorming la dat zeer grote ondernemingen en een hoge graad van industrible concentratie geacht worden bevorder11jk te $z 1 f n$ voor de stimulering van technologiache ontwikleling.

In krittek op dergelijke benaderingen, en gedeeltel1jk ansiluitend b1f het vroegere werk van Schumpeter, wordt in andere theoret 1sche blfiragen meer aandacht gegeven aan de dynamische rol die net name kleine en of nteuwe ondernemingen in het inmovatle-proces spelen. 
Een widen positle vordt gekozen in theorle-varlaten warin een gunstis effect op lnnovatieve ontwikkelingen wordt geschetst in cen Intustriele structur wet een fulste 'vix' van kleinere en grote ondernemingem of bifdragen warin het verband tussen innovatie en induatriele concentratie of grootte van ondernemingen In en zogenaamde ongekeerde $\mathrm{U}$-relat 1 vordt verondersteld. Vaunt theoretisch oogpunt lifken echter varlanten warin wandacht wordt bested an het effect van dynamische veranderingen. sectorale verschillen inter-gectorale effecten van techmologische ontwikkellingen te prefereren.

Het empirisch onderzoek naar de zogenaande 'Sichumpeter controverwe" heeft geleld tot een Inwiddels zeer owrangrijke verzameling atudies wartn weinlg echte consensus valt te onderkennen. Wel wordt in een toenemend antal studies gepleft voor het betrekken van Inter-sectorale verschilien in cechnologische mogel1jkheden als een van de verklarende vartabelen van verachillen in innovativitelt tuasen ondernemingen van verschillende grootte en marktstructuren. Voortbowwend op dergelifke anzetten wordt in deze studle geple1t voor het verbreden van de gpeelruimte in het onderzoek naar de relatie van ondernemingsgrootte en technologische ontwikleling. Belangrljke bowstenen in deze verbreding van de analyse zifn: de verdere operationalieatle van het begrip technologlsche mogelijkheld, de onderschelding van een aantal categorteên van ondernemingen en het introduceren van verschillende 1ninovat1e-strategledn.

Technologische ontwlkkeling dient in de eerste plats gezien te worden als een evolutionatr proces warin zich zowel revolutioasire als incrementele veranderingen kumen voordoen. Voor de analyse van technologische mogelljkheden als medebepalend voor verechlllen tuseen ondernemingen en sectoren dient dit concept eerst verder te worden geconcretiseerd. Asnslutting kan worden gevonden bif onderzoek ut de technologie dynamica en technologie meting, twee velden van onderzoek die voorel door hun mut1disctpilnaire benadering worden gekenwerkt. Technolog1sche ontwikkeling kan verder worden geanalyseerd als de ontwikkeling en verandering binnen en van technologische paradigmata, entgetins 
aneloog aan de ontwikkeling van Ruhn"s wetenschappelljke paradigwata. In een aantal stappen naar een concreter niveau van analyae versichulft het onderzoek naar de ontwlkkeling van 'bastc destgns', naar sleutel-elementen of belangr1jke componenten, on ultelndelijk ult te komen b1J de analyse van technologische trajecten. Aanzetten voor een dergelifk analytisch kader vindt men In een aantal bijdragen tot een evolutionaire theorlevoruling over technologische ontwlkkeling. Dergelljke concepten worden echter nlet altijd even duidelifk gedefinieerd en vooral toegepast in oen algemene schlldering van technologlsche ontulkkelingen.

In dit onderzoek wordt het begrippen-apparaat duldelifker omschreven en in de onderlinge wamenhang geplatst. De concrete toepassing wordt gevonden in de analyse van veranderingen en interdependenties in technologische ontwikkelingen in proces technologiedn, Informatie technologte en proces controle. Voor de analyee van technologische ontwikkelingen in proces controle is een stap verder gegaan in de bestudering van 'basic designs" In de systeemontwikkeling die samenhangen met wisselingen in technologische paradigmata onder invloed van de Introductie van informatle technologie, met name computer technologle. Herblf kan worden angetoond dat ex ne een wisseling van paradigma sprake is van een periode met experimenten waarin geleidelifk een dominant "basic design' nasr voren komt. Vervolgens kan een systeem, zoals dat voor proces controle, worden opgedeeld in sleutel-elementen of belangrifke componenten. Het gehele systeem wordt dan onderverdeeld naar niveau van controle van proces meting tot het top-niveau net wanagement informatie systemen. Voor elk leute1element kan tenslotte een analyse van technologlache trajecten worden gemalkt in termen van techniache verbeteringen in eem drietal generatles, te weten: verouderd, "average practice' en "best practice" en verder de toekomatige veranderingen an de technolog 1sche grens.

Aangezien het economlsch effect van technologliche ontwikkeling nlet alleen tot uitdrukking komt in de verschulving van technische grenzen mar julbt in de diffuale is het van belang om aandacht te 
besteden an diffusie als een zeer belangrijk aspect van techniache veranderlng. In de standaard analyse van diffusie wordt dit proces veelal geanalyseerd als een statisch verschifisel warbif artefact noch populatle van potent1ele gebruikers gedurende het diffusle proces veranderen. Her is difusle geanalyseerd als een dynamisch proces warblj met nawe de technologle zelf gedurende het proces an verandering onderhevig 18. In theorle kan ook in zo' $n$ benadering het diffusile proces als de bekende s-curve worden geprojecteerd alleen wordt deze in een dynamische benadering gegenereerd door de diffusie van opeenvolgende generaties. In deze analyse wordt de diffusie van informatie technologie in de internationale proces controle Industrie gemeten per sleutel-element. Voor de Industriële structuur wordt een onderscheld gemaakt naar een antal grootte-klassen. Op deze wijze krifgt men een gedetailleerd beeld van het diffusie proces als een dynamisch veranderimgsproces in termen van technologische trajecten, de verschillen van diffusie In onderdelen van het systeem en de postet van een aanta1 groepen bedrijuen. Eên van de conclusies van het betreffende emplrische onderzoek 1 is dat vooral de zeer grote ondernemingen het meest geavanceerd $21 \mathrm{Jn}$ bif de diffusie van informatile techmologte en de participatie aan de technologische grens van proces controle.

Het empirisch onderzoek leidt vervolgens tot een verdere analyse van Innovatie en veranderingen in de atructuur van de internationale proces controle apparatuur induatrie. Deze bector 18 in de afgelopen decennla gekenmerkt door een gedeeltelijk creatleve destructle die amenhangt met de wiseling van paradigma in proces controle onder Invloed van de introductie van Informatie technologle. Deze faseling van paradigma dateert van rond het begla van de jaren zestig, cen periode warin ook een toetreding tot de markt van grote elektronica bedrijven en ondernemingen op het gebled van inforwatle technologie valt te constateren. De Indugtrie veranderde in een korte tijd tot een 'sclence based Industry' waarin de achterbl1jvers tot bepalde. minder ontwikkelde, warktntches werden veroordeeld. De sector is gelefdelljk een an de elektronica verwante, Induatrle geworden hetgeen onder andere tot 
ultdrukking komt in de aantallen met informat le techologie verbonden bedrifven die door de leldende ondernemingen aljn overgenomen. De verandering van de Industriele structurur heeft vooral het karakter van een "verjonging" van een "volwassen" meet- en regelindustrie. In de verjonging blijken zowel kleinere RaD Intensleve als zeer Brote en gediversificeerde ondernemingen een vooraanataande rol te spelen.

Voor de vraag naar het verband tussen grootte van ondernemingen en Innovatle 18 gebruik gemakt van een grootte-1ndeling die nogal afwijkt van standaard Indelingen en die gebaseerd is op de frequentileverdeling in een internationale context. Voor het meten van Innovatle 18 gebrulk gemaakt van verschillende indicatoren, die betrekking hebben op zowel de R\&D-1nput, de output in nleuwe produkten, als de toepassing van "best practice" technologie. Tevens is met behulp van principale componenten analyse een verband gezocht tussen alternatieve Innovatlestrategleen en grootteklasse warb1j overlgens in deze sector geen signlficant verband is gevonden. Wel is duldelijk dat vooral een belangrijk deel van de kleinere RSD Intensteve ondernemingen en de zeer grote multinationale en multi-divisionele ondernemingen tot de meer innovatieve ondernemingen kunnen worden gerekend.

Al met al levert deze studie een bljdrage aan heterodoxe atromingen binnen het economisch onderzoek naar de gevolgen van technologische ontw1kkelingen voor de Industriele structuur. Ditgaande van de reconstructle van klassieke theorlesen en voortbouwend op een reeks van theoretische bijdragen wordt een experimenteel analytlach kader 'getest' waarmee een 'dlepte analyae" van technologliche ontwikkelingen en Industrible atructuurveranderingen mogelifk wordt genaakt. Centraal in deze benaderlng staan de asymetrie van ondermeningen, de dynamische veranderingen in technologie en diffuble processen en de wederzifdse beinvloeding van technologle en haar ongeving. 


\section{Curriculum vitae}

De auteur van dit proefschrift is op 4 februarl 1950 te 's Gravenhage geboren. Na een Mulo-oplelding is hif tot 1972 werkzan geweegt In diverse beroepen. Van 1968 tor 19721 set goed gevolg het avondcollege Noctua te "Graveahage doorlopen, deze opleiding is afgesloten met het diploms Atheneum. Van 1972 tot 1978 heeft de auteur Economische Soclologie en Polltleke Bconomie gestudeerd an de RIJksuniversitelt Leiden. Het doctoraal diploma 1a curm laude behald.

Vanaf 1978 is de ateur vetenschappe11jk (hoofd-) onderaoeher geveest bij het studfecentrum voor Technologie en Beleld mo. Sinds 1 Julf 1988 is hif werkzam als projectlelder b1f het Mastricht Economic Research institute on Innovation and Technology (MERIT) van de Rijksuniversiteit Limburg.

Voor de totstandkoming van dit proefschrift dienen, nast de reeds cerder genoemde Instantles, collega's blj het studiecentrum voor Technologie en Beleid TWO te worden genoemd die wet de auteur hebben samengewerkt in een aantal onderzoeksprojecten, die gedee1telljk hebben bijgedragen tot dit proefschrift. In dat verband moeten met name Paul Ralff, Jaap Korpel en Jos Schakenragd worden genoemd. Speclale woorden van dank gaan uit naar Martina van Amersfoort die de moellifke taak had om van een antal slordige manuscripten een nette elndversle te produceren, dat laatste is met veel vakvrouwschap gelukt. 